\title{
Electron Transfer Reactions: KOtBu (but not NaOtBu) Photo- reduces Benzophenone, under Activation by Visible Light
}

Giuseppe Nocera ${ }^{a \neq}$ Allan Young, a $¥$ Fabrizio Palumbo, ${ }^{a}$ Katie J. Emery, ${ }^{a}$ Graeme Coulthard, ${ }^{\text {a Thomas McGuire }}$, ${ }^{\mathrm{b}}$ Tell Tuttle ${ }^{\mathrm{a} *}$ and John A. Murphy ${ }^{a *}$

aDepartment of Pure and Applied Chemistry, University of Strathclyde, 295 Cathedral Street, Glasgow, G1 1XL, U.K. boncology, IMED Biotech Unit, AstraZeneca, Building 310, Cambridge Science Park, 319 Milton Road, Cambridge CB4 0WG, U.K.

\section{Supporting Information Placeholder}

\begin{abstract}
Long-standing controversial reports of electron transfer from $\mathrm{KO} t \mathrm{Bu}$ to benzophenone have been investigated and resolved. The mismatch in the oxidation potential of $\mathrm{KO} t \mathrm{Bu}$ $(+0.10 \mathrm{~V} v s . \mathrm{SCE}$ in DMF) and the first reduction potential of benzophenone (of many values cited in the literature, the least negative value is $-1.31 \mathrm{~V} v s$. SCE in DMF), preclude direct electron transfer. Experimental and computational results now establish that a complex is formed between the two reagents, with the potassium ion providing the linkage, which markedly shifts the absorption spectrum to provide a tail in the visible light region. Photoactivation at room temperature by irradiation at defined wavelength ( $365 \mathrm{~nm}$ or $400 \mathrm{~nm})$, or even by winter daylight, leads to the development of the blue color of the potassium salt of benzophenone ketyl, whereas no reaction is observed when the reaction mixture is maintained in darkness. So, no electron transfer occurs in the ground state. However, when photoexcited, electron transfer occurs within a complex formed from benzophenone and $\mathrm{KOtBu}$. TDDFT studies match experimental findings and also define the electronic transition within the complex as $n \rightarrow \pi^{*}$, originating on the butoxide oxygen. Computation and experiment also align in showing that this reaction is selective for $\mathrm{KO} t \mathrm{Bu}$; no such effect occurs with $\mathrm{NaO} t \mathrm{Bu}$, providing the first case where such alkali metal ion selectivity is rationalized in detail. Chemical evidence is provided for the photoactivated electron transfer from $\mathrm{KO} t \mathrm{Bu}$ to benzophenone: tert-butoxyl radicals are formed and undergo fragmentation to form (acetone and) methyl radicals, some of which are trapped by benzophenone. Likewise, when $\mathrm{KOC}(\mathrm{Et})_{3}$ is used in place of $\mathrm{KO} t \mathrm{Bu}$, then ethylation of benzophenone is seen. Further evidence of electron transfer was seen when the reaction was conducted in benzene, in the presence of $p$ iodotoluene; this triggered BHAS coupling to form 4-methylbiphenyl in $74 \%$ yield.
\end{abstract}

\section{Introduction}

Alkoxides of alkali metals are widely used in organic chemistry as powerful bases. In the past decade, however, these alkoxides have played a key role in an extremely wide range of reactions that involve, or are proposed to involve, single electron transfer - representative examples are cited here. ${ }^{1-10}$ This is paradoxical, because alkoxides are very resistant to oxidation, due to electronegativity of oxygen and the consequent instability of alkoxyl radicals.
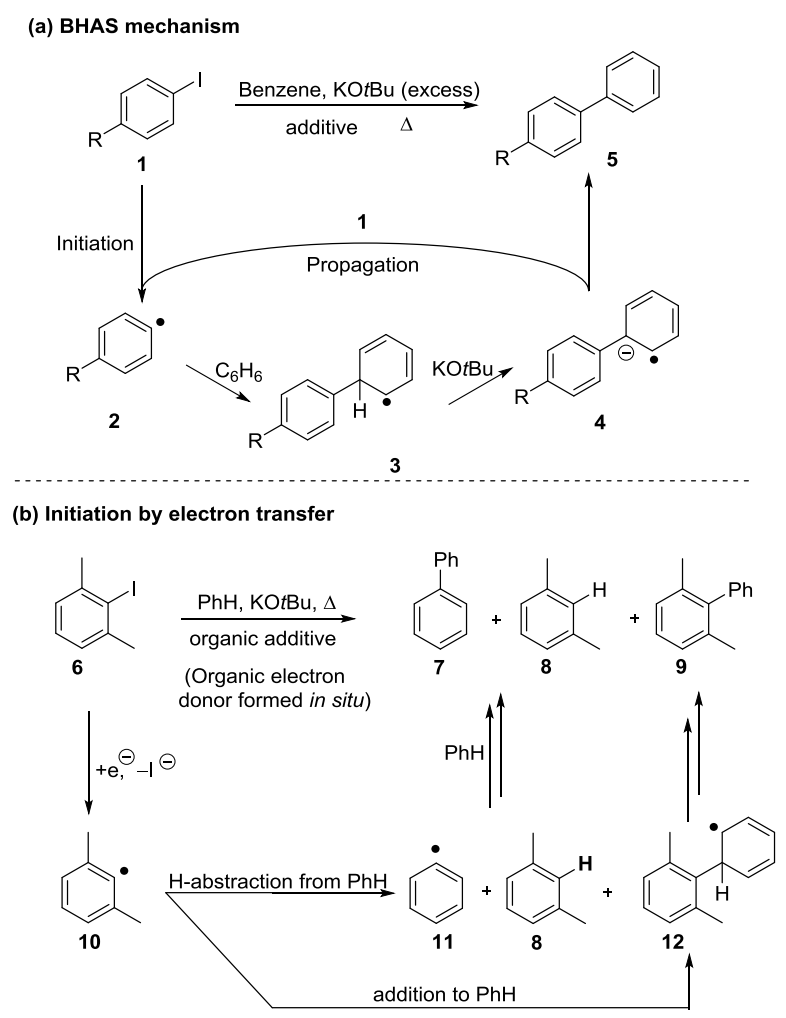

(c) Some additives and their in situ derived electron donors<smiles>CCOc1ccccn1</smiles>

13

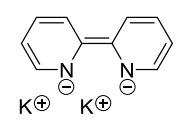

14

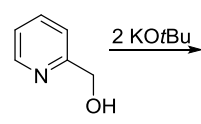

15

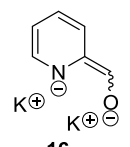

16
Scheme 1. (a) BHAS mechanism. ${ }^{2}$ (b) Initiation by electron transfer. ${ }^{5 b}$ (c) Examples ${ }^{56,10}$ of additives and their proposed electron donors derived by reaction with $\mathrm{KO} t \mathrm{Bu}$.

Our interest in these alkoxides, and particularly $\mathrm{KO} t \mathrm{Bu}$, arose from our studies of the initiation of the Base-Promoted Homolytic Aromatic Substitution (BHAS) class of reactions, ${ }^{10}$ (Scheme 1a), where $\mathrm{KO} t \mathrm{Bu}^{1-10}$ (sometimes $\mathrm{NaO} t \mathrm{Bu}^{1 \mathrm{c}, 2 \mathrm{c}, 3 \mathrm{a}}$ ) promotes the coupling of aryl halides to arenes in the presence of a range of special organic additives. The reactions occur through the conversion of 
aryl halides $\mathbf{1}$ to aryl radicals $\mathbf{2}$ by means of the chain reaction shown.

Some authors proposed that initial radical formation is the result of direct electron transfer from $\mathrm{KO} t \mathrm{Bu}$ or a complex of $\mathrm{KO} t \mathrm{Bu}$ with a ligand to the aryl halide, but our computational and experimental studies indicated ${ }^{5 b, f}$ that in situ chemical reaction between $\mathrm{KO} t \mathrm{Bu}$ and a wide range of additives instead afforded very electron-rich compounds that behaved as powerful organic electron donors (e.g. 14, ${ }^{5 \mathrm{~b}} \mathbf{1 6}^{7 \mathrm{~d}, \mathrm{e}}$ in Scheme 1c). These compounds are needed in vanishingly small amounts, as their role is simply to initiate radical formation; once initiated, conversion is amplified through the radical chain reaction shown.

BHAS reaction with substrate 6 (Scheme $1 \mathrm{~b}$ ), has been exploited by us as a very reliable and sensitive indicator of the formation of strong electron donors in solution. Substrate $\mathbf{6}$ does not react with $\mathrm{KO} t \mathrm{Bu}$; however, when $\mathrm{KO} t \mathrm{Bu}$ reacts with a suitable additive to form a strong electron donor, electron transfer to $\mathbf{6}$ occurs, resulting in formation of aryl radical 10, and an iodide ion. Radical $\mathbf{1 0}$ adds to benzene to form radical $\mathbf{1 2}$ and ultimately leads to biaryl 9. But the ortho-methyl groups in $\mathbf{1 0}$ make the addition to benzene a challenging reaction, allowing a competing hydrogen atom abstraction from benzene to occur, thereby forming radical $\mathbf{1 1}$ together with xylene $\mathbf{8}$, the latter as a volatile by-product. Radical 11 reacts with the solvent benzene, ultimately forming biphenyl 7 . The formation of 7 and 9 in a defined ratio of $c a .3: 1$ is a hallmark of the BHAS reaction on substrate 6 . Because of its hindered nature, the yields of coupled product from substrate $\mathbf{6}$ are not high, but the substrate gives a very clear differentiation between the presence of electron donors and their absence and, in this way, the mechanistic information that it provides is very valuable. ${ }^{5 b, 5 \mathrm{f}}$

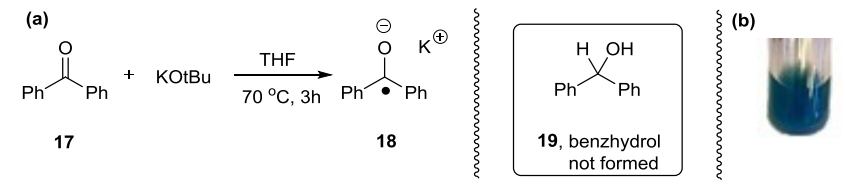

Scheme 2 (a) Ketyl salt formation; ${ }^{12}$ no benzhydrol 19 was formed. (b) Photograph shows blue ketyl salt of benzophenone in our repeat of Ashby experiment, but at $70{ }^{\circ} \mathrm{C}$.

Discussion of electron transfer in reactions $\mathrm{KO} t \mathrm{Bu}$ with benzophenone goes back to Russell et al. in $1962,{ }^{11 \mathrm{a}}$ who showed that radicals were generated when benzophenone and its dihydro derivative, benzhydrol, 19, were mixed in the presence of $\mathrm{KO} t \mathrm{Bu}$ in DMSO, although the paper did not discuss mechanism. In 1978, Screttas and Cazianis proposed ${ }^{11 \mathrm{~b}}$ electron transfer from lithium $s$ butoxide to fluorenones as a result of detection of ketyl radicals. The story was taken up in 1982 by Ashby et al. ${ }^{12}$ who observed the blue color of the potassium ketyl of benzophenone on reaction of benzophenone with $\mathrm{KO} t \mathrm{Bu}$ (Scheme 2). Ashby attributed the reaction to direct electron transfer from $\mathrm{KO} t \mathrm{Bu}$ to benzophenone. Although not considered then, the reduction potential for benzophenone to its ketyl radical anion (cited values vary from $-1.31 \mathrm{~V}$ $v s$. SCE in DMF to $-2.2 \mathrm{~V})^{13 \mathrm{a}-\mathrm{c}}$ and oxidation potential of $\mathrm{KO}^{t} \mathrm{Bu}$, $\left(+0.1 \mathrm{~V}\right.$ in DMF, vs. SCE), ${ }^{6 \mathrm{e}}$ indicate that this is not possible as a direct bimolecular electron transfer. With our background in the in situ formation of organic electron donors like $\mathbf{1 4}$ and 16, we therefore explored whether formation of organic electron donors could explain the Ashby reactions. ${ }^{14}$

\section{Results and Discussion}

Our first task was to validate the original observations of Ashby qualitatively. Adding sodium metal or potassium metal to a solution of benzophenone $(\mathbf{1 7}, \mathrm{BZP})(0.5 \mathrm{mmol})$ in THF $(2.5 \mathrm{~mL})$ afforded the blue color of the ketyl at ambient temperature. No col- (a)

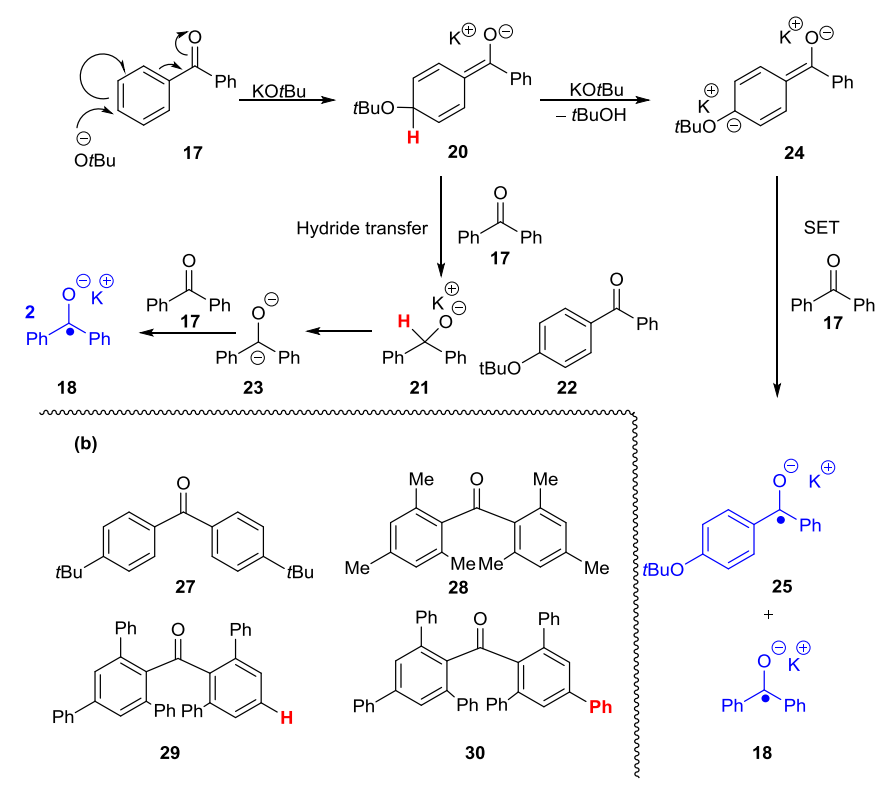

Scheme 3 (a) A proposal for in situ formation of electron donors from $\mathrm{KOtBu}+\mathrm{Ph}_{2} \mathrm{CO}$. (b) Diarylketones that were synthesized for this study.

or developed when $\mathrm{KO} t \mathrm{Bu}$ ( 2 equiv) was instead added to benzophenone at room temperature, but heating to $70{ }^{\circ} \mathrm{C}$ produced the characteristic blue color after $3 \mathrm{~h}$ [Scheme 2(b)], supporting Ashby's observation. Given sufficient time, the blue color decays, as reported. Work-up led to isolation of benzophenone, and no benzhydrol 19 was detected, again supporting Ashby's report. Interestingly, and in contrast to $\mathrm{KO} t \mathrm{Bu}, \mathrm{NaO} t \mathrm{Bu}$ ( 2 equiv) showed no evidence of ketyl formation or other reaction under either set of conditions (see Fig S11 in S.I. file).

We now proposed a number of ways in which organic electron donors ${ }^{15}$ might arise in these reactions, one example of which is shown in Scheme 3 (see also S.I.) Attack by $\mathrm{KO} t \mathrm{Bu}$ in the paraposition of benzophenone $\mathbf{1 7}$ would afford anionic intermediate 20. (Attack in the ortho-position should be a comparable alternative, and was considered, see S.I.). Two fates might await 20: (a) hydride transfer to a molecule of benzophenone 17 would afford 21 and 22 (see ref $^{5 f}$ for transfer of hydride from an alkoxide under BHAS conditions). As already stated, no benzhydrol 19 is formed in this reaction, so if $\mathbf{2 1}$ were formed, it would need to evolve in a different way; deprotonation would afford dianion 23 (see ref. ${ }^{7 \mathrm{~d}}$ for formation of dianions with $\mathrm{KO} t \mathrm{Bu}$ under BHAS conditions) which would be a strong electron donor and could reduce benzophenone $\mathbf{1 7}$ to form two ketyl radical derivatives $\mathbf{1 8}$. (b) a second possible fate of molecule $\mathbf{2 0}$ would involve deprotonation to afford dianion 24, another candidate for donating an electron to benzophenone 17. The result of the electron transfer would be two potassium ketyl species, $\mathbf{1 8}$ and $\mathbf{2 5}$.

To explore this proposal, substituted benzophenones 27-30 were prepared (see SI for details). If addition of $\mathrm{KO} t \mathrm{Bu}$ to the aryl rings of these substrates is valid, then at least some of these substrates, substituted in ortho and/or para positions, are likely to afford significantly diminished amounts of the potassium ketyl on comparison to 17. In particular, a notable difference should be seen between closely related substrates like $\mathbf{2 9}$ (attack at the free paraposition, followed by deprotonation is possible), and 30, (where, even if addition of tert-butoxide occurs at the substituted para position, subsequent deprotonation is not possible, so that an electron donor should not be able to form). We recognized that the simple qualitative color test for ketyl formation could be compli- 
cated with some of these substrates due to the extended chromophores of $\mathbf{2 9}$ and $\mathbf{3 0}$ and also to the likely variation in kinetics, compared to substrate 17. So we deployed the BHAS reaction with substrate 6 as a sensitive test (Table 1). The experiments with 17 were repeated in triplicate, and the yields were repeatable.

Table 1. BHAS reactions of iodoarene 6.

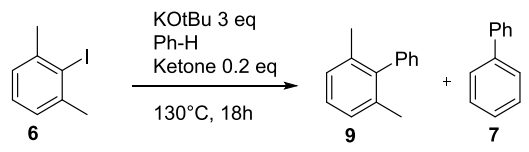

\begin{tabular}{|c|c|c|c|}
\hline Entry & Ketone & $\mathbf{9}^{\mathrm{a}}(\mathbf{\%}$ yield $)$ & $\mathbf{7}^{\mathrm{a}}(\%$ yield $)$ \\
\hline $1^{\mathrm{c}}$ & - & 0.2 & 0.4 \\
\hline $2^{\mathrm{c}}$ & $\mathbf{1 7}$ & 1.2 & $3.5^{\mathrm{b}}$ \\
\hline 3 & $\mathbf{2 7}$ & 1.0 & 3.2 \\
\hline 4 & $\mathbf{2 8}$ & 0.7 & 1.8 \\
\hline 5 & $\mathbf{2 9}$ & 0.8 & $2.4^{\mathrm{b}}$ \\
\hline 6 & $\mathbf{3 0}$ & 0.4 & $1.2^{\mathrm{b}}$ \\
\hline
\end{tabular}

a Yield calculated via NMR using 1,3,5-trimethoxybenzene as internal standard. ${ }^{\mathrm{b}}$ Yield deduced using the ratio 1:3 (9:7) calculated after isolation of the mixture of the coupled products. ${ }^{\mathrm{c}}$ Average of 3 runs.

As usual with substrate $\mathbf{6}$, the yields of the biphenyl products, 7 and 9, were not high, but they were at least three times higher than the yields from the non-zero yield in blank reactions. ${ }^{16}$ The important point to note is that the BHAS reaction was not at 'blank' levels for any of the ketones, indicating that factors other than shown in Scheme 3 were at play. Moreover, we did not succeed in detecting or isolating any products arising from addition of tertbutoxide anion to any of the ketones. Coupled with computational studies which indicated unfavorable energy profiles for the proposals in Scheme 3 (see SI), this caused us to think afresh about these reactions.

While performing repeat experiments on the formation of the potassium salt of benzophenone ketyl through reaction with $\mathrm{KOtBu}$ on many different days, it was noticed that the time required for the development of the blue color varied by day. During a (rare) sunny day, we noticed that the switch to the blue color was much faster than usual. Performing parallel experiments when sunlight was present with (i) exposed and (ii) foil-covered reactions, showed the result to be strongly dependent on the irradiation.

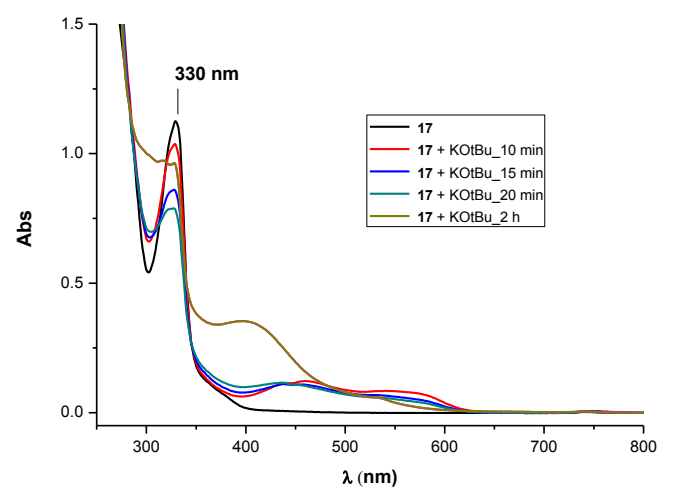

Figure 1. UV measurements of $\mathbf{1 7}(\mathrm{BZP})+\mathrm{KO} t \mathrm{Bu}$ with time in THF.
A preliminary study of the UV absorption of $\mathbf{1 7}$ and of mixtures of $\mathbf{1 7}$ with $\mathrm{KO} t \mathrm{Bu}$ in THF was performed (Figure 1).

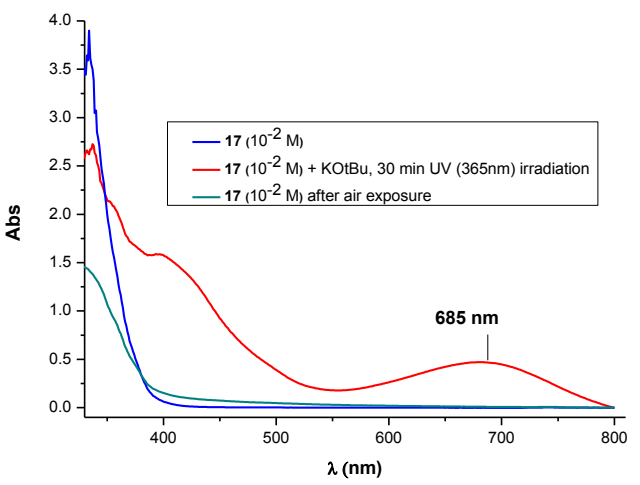

Figure 2. UV measurement of $\mathbf{1 7}\left(10^{-2} \mathrm{M}\right.$ in THF $)+\mathrm{KO} t \mathrm{Bu}$ preand post-irradiation.

Benzophenone does not absorb radiation at $>400 \mathrm{~nm}$ (black trace). When $\mathrm{KO} t \mathrm{Bu}$ was added, a tail in the absorption in the range of 400-600 $\mathrm{nm}$ was detected; we attribute this to the formation of a transient complex or complexes. With time, the absorption profile changed with the appearance of a new maximum around $400 \mathrm{~nm}$ (See Figure 1, trace marked as: ' $17+\mathrm{KO} t \mathrm{Bu}{ }_{2}$ h'). This complex is discussed below, based on investigation through computational chemistry. Therefore we irradiated the mixture of $\mathrm{KO} t \mathrm{Bu}$ and 17 in distilled THF with UV $(365 \mathrm{~nm}$, see Figure 2) and polychromatic visible light (see S.I.). In both cases, the blue coloration developed. Analysis via UV-vis spectrometry revealed the appearance of a broad band around $\lambda=685 \pm 30 \mathrm{~nm}$, diagnostic of the ketyl radical anion of $17^{17}$ (Figure 2).

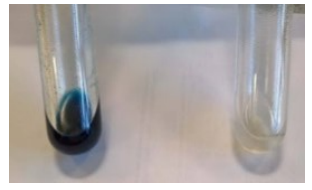

Figure 3. Reaction tubes containing $\mathrm{KO} t \mathrm{Bu}$ and $\mathbf{1 7}$ in benzene (a) left: exposed to $400 \mathrm{~nm}$ light and (b) right: shielded from light by covering in foil.

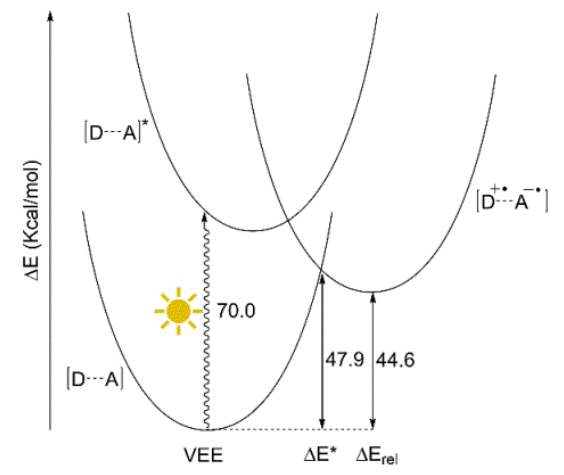

Figure 4. TD-DFT calculated vertical excitation energy (VEE) and DFT calculated single electron transfer energies (calculated using the complexation method $)^{18}$ for the complex of benzophenone $\mathbf{A}$ and $\mathrm{KO} t \mathrm{Bu}$ (monomer) D. Geometries optimized using M06-2X/6-31++G(d,p) and subsequent single point energy or TDDFT calculations carried out using CAM-B3LYP/6-31++G(d,p), all with CPCM solvation parameters for THF. 
Given the absorption of the complex just above $400 \mathrm{~nm}$, we also irradiated reaction tubes containing $\mathrm{KO} t \mathrm{Bu}$ and benzophenone $\mathbf{1 7}$ in benzene with $400 \mathrm{~nm}$ LED light sources. Comparison was again made with a foil-covered reaction, conducted side-by-side and at the same time (see Figure 3 ). The Figure very clearly shows the effect of the LED light source on the reaction.

(a)
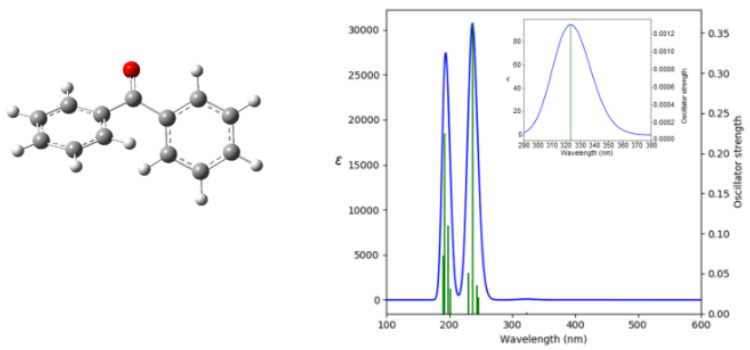

(b)
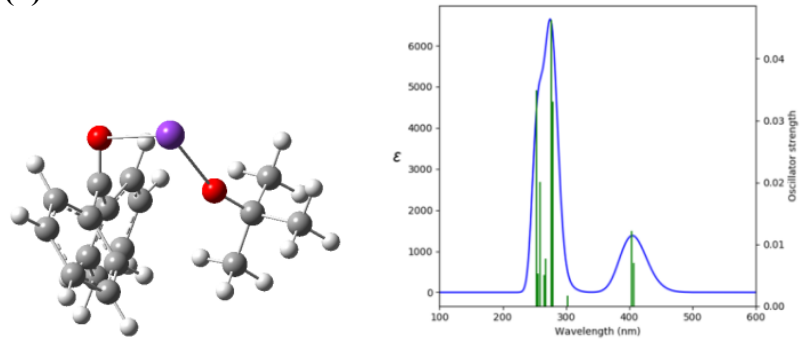

(c)
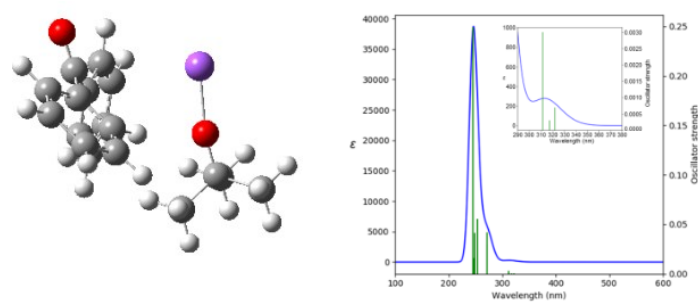

Figure 5 (a) Benzophenone 17 (left) and its computed absorption spectrum $^{19}$ (right) with expansion of weak n- $\pi^{*}$ at $332 \mathrm{~nm}$ inset. (b) complex of $\mathbf{1 7}$ with $\mathrm{KO} t \mathrm{Bu}$ (left) and predicted spectrum showing the $\mathrm{n}-\pi^{*}>400 \mathrm{~nm}$ (right) (c) complex of 17 with $\mathrm{NaO} t$ $\mathrm{Bu}$ (left) and predicted spectrum (right).

To understand the visible light promoted formation of the blue benzophenone ketyl radical anion, time-dependent density functional theory (TD-DFT) calculations were conducted. Initially, the first singlet excited state of benzophenone was calculated, which corresponds to an $n-\pi^{*}$ excitation occurring at $332 \mathrm{~nm}$ or $3.73 \mathrm{eV}$. It was therefore clear that no visible light excitation of benzophenone alone could be taking place. We therefore decided to study the complex between a monomer of $\mathrm{KO}^{t} \mathrm{Bu}$ and benzophenone, which exhibits singlet excitations at $406 \mathrm{~nm}(3.05 \mathrm{eV}$ or 70 $\mathrm{Kcal} / \mathrm{mol})$ and $404 \mathrm{~nm}(3.07 \mathrm{eV})$ which correspond to CT from the [HOMO] and [HOMO-1], both residing on $\mathrm{KO}^{t} \mathrm{Bu}$, to the LUMO, residing on benzophenone. This suggests that it is indeed possible to photoexcite a complex of $\mathrm{KOtBu}$ and benzophenone using visible light. The complex between $\mathrm{NaOtBu}$ monomer and benzophenone however, does not exhibit any excitation in the visible re- gion, with excitations occurring at $322 \mathrm{~nm}(3.85 \mathrm{eV})$ and $318 \mathrm{~nm}$ $(3.90 \mathrm{eV})$ corresponding to CT from the [HOMO] and [HOMO1], both residing on $\mathrm{NaO} t \mathrm{Bu}$, to the LUMO, residing on benzophenone. This lack of visible excitation (or indeed excitation around $365 \mathrm{~nm}$ ) can explain why no ketyl radical anion is observed in reactions with $\mathrm{NaO} t \mathrm{Bu}$.

Marcus theory calculations for SET between ground-state $\mathrm{KO}^{t} \mathrm{Bu}$ and benzophenone (Figure 4) predicts a relative electronic energy of $44.6 \mathrm{kcal} / \mathrm{mol}\left(\Delta \mathrm{G}_{\mathrm{rel}}=42.5 \mathrm{kcal} / \mathrm{mol}\right)$ with a calculated electronic activation energy of $47.9 \mathrm{kcal} / \mathrm{mol}\left(\Delta \mathrm{G}^{*}=44.0 \mathrm{kcal} / \mathrm{mol}\right)$. These results indicate that ground state electron transfer between these reactants is not possible. In order to overcome the unfavorable energetics associated with ground state SET, visible light excitation of the reactant complex followed by charge separation would furnish the SET product complex.
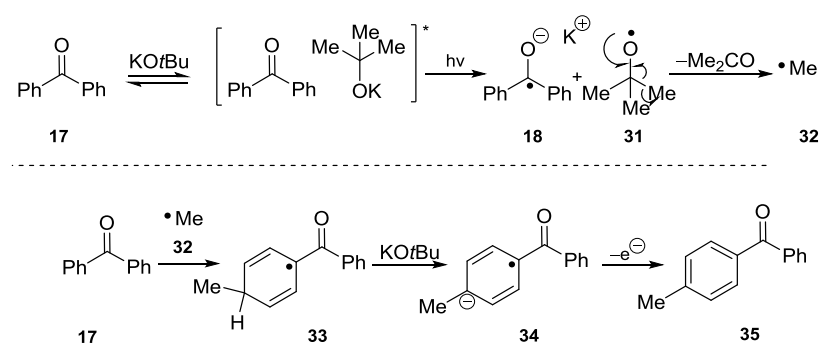

Scheme 4. Fragmentation of tert-butoxyl radicals leading to formation of methylbenzophenone.

In reactions where electron transfer from tert-butoxide anions to benzophenone occurs, evidence ought to be available to support intermediacy of tert-butoxyl radicals and of the potassium ketyl of benzophenone. tert-Butoxyl radicals undergo fragmentation very rapidly to form acetone and methyl radicals (Scheme 4$)^{20}$ In our reactions with benzophenone in THF as solvent, methyl radicals can undergo hydrogen atom abstraction from the solvent, but they can also add to benzophenone to give methylbenzophenone. Whereas the formation of the ketyl occurs with irradiation at 365 $\mathrm{nm}$, or $400 \mathrm{~nm}$ or daylight, it occurs most rapidly with excitation at $365 \mathrm{~nm}$. Under these conditions, we looked for benzophenonerelated products and detected and characterized the monomethylated analogue of benzophenone by GCMS. To confirm this result, we replaced $\mathrm{KO} t \mathrm{Bu}$, (i.e. $\mathrm{KOCMe}_{3}$ ) by $\mathrm{KOCEt}_{3}$, and characterized the monoethylated benzophenone GCMS. ${ }^{21}$

Table 2:

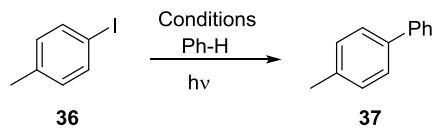

\begin{tabular}{|c|c|c|c|}
\hline Entry & Conditions $^{\mathrm{a}}$ & Light $(\lambda)$ & $\mathbf{3 7}$ (yield \%) \\
\hline 1 & $\begin{array}{c}\mathbf{1 7}, 1 \mathrm{eq} \\
\text { KO } t \mathrm{Bu} 2 \text { eq. }\end{array}$ & $365 \mathrm{~nm}$ & 74 \\
\hline 2 & KO $t \mathrm{Bu} 2$ eq, & $365 \mathrm{~nm}$ & 12 \\
\hline
\end{tabular}

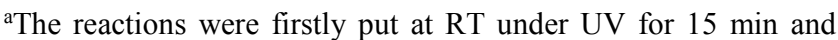
then placed in absence of irradiation at $130^{\circ} \mathrm{C}$ for $18 \mathrm{~h}$. 
To look for further evidence of electron transfer, we examined the BHAS reaction in benzene with $p$-iodotoluene $\mathbf{3 6}$, a substrate that is much less hindered than substrate $\mathbf{6}$, and so the yield should be higher than for substrate $\mathbf{6}$. As radical generation is simply part of the initiation process, we irradiated at $365 \mathrm{~nm}$ for $15 \mathrm{~min}$ and then turned off the irradiation and heated for $18 \mathrm{~h}$ at $130^{\circ} \mathrm{C}$. This afforded 4-methylbiphenyl (74\%, Table 2); a blank experiment in which benzophenone was omitted gave 4-methylbiphenyl in $12 \%$ by comparison.

Conclusions. The historical observation by Ashby et al. ${ }^{12}$ of formation of the potassium ketyl of benzophenone from reaction of benzophenone with $\mathrm{KO} t \mathrm{Bu}$ was hitherto unexplained. The redox potentials of the two molecules are seriously mismatched, so that an outer sphere electron transfer can be discounted. Our studies show that mixing $\mathrm{KO} t \mathrm{Bu}$ with benzophenone gives rise to a metastable complex with absorption just above $400 \mathrm{~nm}$ that can be excited in daylight or under activation with LED illumination at 400 $\mathrm{nm}$ or with UV illumination at $365 \mathrm{~nm}$, resulting in electron transfer from the alkoxide to benzophenone 17. The reaction seems very specific to $\mathrm{KO} t \mathrm{Bu}$; changing to $\mathrm{NaO} t \mathrm{Bu}$ gave no reaction. ${ }^{22}$ The important point to note is that while Ashby's observation of electron transfer is validated here, his conclusion that this reaction is a ground state reaction is wrong. $\mathrm{KO} t \mathrm{Bu}$ can only transfer an electron to benzophenone upon photoactivation that is facilitated by a special complex formed between $\mathrm{KOtBu}$ and benzophenone.

Benzophenone plays a central role in pure and applied organic photochemistry. ${ }^{23}$ Although benzophenone absorbs strictly in the $\mathrm{UV}$, this paper reveals that formation of discrete complexes can lead to absorption in the visible region of the spectrum. This may be part of a much more general phenomenon allowing access to benzophenone photochemistry with visible light. In connection with that, two recent reports ${ }^{24}$ highlighted 'excitations of benzophenone' with visible light sources, although no characterization of the absorbing species was carried out. Perhaps complexation also leads to species that absorb visible light. Potassium tertbutoxide is an unusual partner for electron transfer reactions. A recent paper highlighted $\mathrm{KO} t \mathrm{Bu}$ as an electron donor to a highly oxidising iridium complex ${ }^{25}$ and backed this with Stern-Volmer studies to show the involvement of the $\mathrm{KO} t \mathrm{Bu}$, but our paper now discloses the first characterized case of electron transfer to an organic substrate. It may be that further recently reported cases of the activity of $\mathrm{KO} t \mathrm{Bu}$ as an electron donor actually constitute complexes that don't occur in the ground state but are photoactivated by sunlight..$^{6 e}$ Placing this in context, the exploitation of organic molecular complexes absorbing visible light has been highlighted recently by Melchiorre and others as a growth area, ${ }^{26,7 \mathrm{e}, 8 \mathrm{i}}$ and adds to other recent developments ${ }^{27}$ in chemical reactivity triggered by visible light.

Acknowledgements. We thank the University of Strathclyde and AstraZeneca for support; the Generalitat Valenciana (Spain) for funding a postdoctoral fellowship (to F.P.). High resolution mass spectrometry was carried out at the EPSRC National Mass Spectrometry Centre, Swansea University. Computational results were obtained using the EPSRC funded ARCHIE-WeSt High Performance Computer (www.archie-west.ac.uk). EPSRC grant no. EP/K000586/1. We thank Drs. Glynn Williams and Lee Edwards (GSK) for calibrating our LED device, and Dr. Xu Chao for helpful discussions.

\section{References}

$¥$ These authors contributed equally to the research.

(1) (a) Yanagisawa, S.; Ueda, K.; Taniguchi, T.; Itami, K. Org. Lett. 2008, 10, 4673-4676. (b) Sun, C.-L.; Li, H.; Yu, D.-G.; Yu, M.; Zhou, X.; Lu, X.-Y.; Huang, K.; Zheng, S.-F.; Li, B.-J.; Shi, Z.-J. Nat. Chem. 2010, 2, 1044-1049. (c) Shirakawa, E.; Itoh, K.-I.; Higashino, T.; Hayashi, T. J. Am. Chem. Soc. 2010, 132, 15537-15539. Note: this paper also demonstrated effective reactions with $\mathrm{NaOtBu}$. (d) Liu, W.; Cao, H.; Zhang, H.; Zhang, H.; Chung, K. H.; He, C.; Wang, H.; Kwong, F. Y.; Lei, A. J. Am. Chem. Soc. 2010, 132, 16737-16740.

(2) (a) Sun, C. L.; Gu, Y.-F.; Wang, B.; Shi, Z.-J. Chem.-Eur. J. 2011, 17, 10844-10847. (b) Sun, C. L.; Gu, Y.-F.; Huang, W.-P.; Shi, Z.-J. Chem. Commun. 2011, 47, 9813-9815. (c) Shirakawa, E.; Zhang, X.; Hayashi, T. Angew. Chem., Int. Ed. 2011, 50, 4671-4674. (d) Yong, G.-P.; She, W.-L.; Zhang, Y.-M.; Li, Y.Z. Chem. Commun. 2011, 47, 11766-11768. (e) Rueping, M.; Leiendecker, M.; Das, A.; Poisson, T.; Bui, L. Chem. Commun. 2011, 47, 10629-10631. (f) Qiu, Y.; Liu, Y.; Yang, K.; Hong, W.; Li, Z.; Wang, Z.; Yao, Z.; Jiang, S. Org. Lett. 2011, 13, 3556-3559. (g) Roman, D. S.; Takahashi, Y.; Charette, A. B. Org. Lett. 2011, 13, 3242-3245.

(3) Shirakawa, E.; Hayashi, T. Chem. Lett. 2012, 41, 130-134. (b) Liu, H.; Yin, B.; Gao, G. Z.; Li, Y.; Jiang, H. Chem. Commun. 2012, 48, 2033-2035. (c) Chen, W.-C.; Hsu, Y.-C.; Shih, W.-C.; Lee, C.-Y.; Chuang, W.-H.; Tsai; Chen, P. P.-Y.; Ong, T.-G. Chem. Commun. 2012, 48, 6702-6704. (d) Pieber, B.; Cantillo, D.; Kappe, O. C. Chem.-Eur. J. 2012, 18, 5047-5055. (e) Bhakuni, B. S.; Kumar, A.; Balkrishna, S. J.; Sheikh, J. A.; Konar, S.; Kumar, S. Org. Lett. 2012, 14, 2838-2841. (f) Ng, Y. S.; Chan, C. S.; Chan, K. S. Tetrahedron Lett. 2012, 53, 3911-3914. (g) De, S.; Ghosh, S.; Bhunia, S.; Sheikh, J. A.; Bisai, A. Org. Lett. 2012, 14, 4466-4469. (h) Tanimoro, K.; Ueno, M.; De, S.; Ghosh, S.; Bhunia, S.; Sheikh, J. A.; Bisai, A. Org. Lett. 2012, 14, 4466-4469. (i) Tanimori, S. J. Org. Chem. 2012, 77, 7844-7849. (j) Wu, Y.; Wong, S. M.; Mao, F.; Chan, T. L.; Kwong, F. Y. Org.Lett. 2012, 14, 5306-5309.

(4) (a) Zhao, H.; Shen, J.; Guo, J.; Ye, R.; Zeng, H. Chem. Commun. 2013, 49, 2323-2325. (b) Buden, M. E.; Guastavino, J. F.; Rossi, R. A. Org. Lett. 2013, 15, 1174-1177. (c) Liu, W.; Tian, F.; Wang, X.; Yu, H.; Bi, Y. Chem. Commun. 2013, 49, 2983-2985. (d) Kumar, A.; Bhakuni, B. S.; Prasad, Ch.; Durga, S.; Kumar, S.; Kumar, S. Tetrahedron 2013, 69, 5383-5392. (e) De, S.; Subhadip, M.; Mishra, S.; Kakde, B. N.; Dey, D.; Bisai, A. J. Org. Chem. 2013, 78, 7823-7844. (f) Sharma, S.; Kumar, M.; Kumar, V.; Kumar, N. Tetrahedron Lett. 2013, 54, 4868-4871. (g) Dewanji, A.; Murarka, S.; Curran, D. P.; Studer, A. Org. Lett. 2013, 15, 6102-6105. (h) Oksdath-Mansilla, G.; Argüello J. E.; Peñéñory, A. B. Tetrahedron Lett. 2013, 54, 1515-1518.

(5) (a) Wu, Y.; Choy, P. Y.; Kwong, F. Y. Org. Biomol. Chem. 2014, 12, 6820-6823. (b) Zhou, S.; Anderson, G. M; Mondal, B.; Doni, E.; Ironmonger, V.; Kranz, M.; Tuttle T.; Murphy, J. A. Chem. Sci. 2014, 5, 476-482. (c) Guastavino, J. F.; Buden, M. E.; Rossi, R. A. J. Org. Chem, 2014, 79, 9104-9111. (d) Bhakuni, B. S.; Yadav, A.; Kumar, S.; Patel, S.; Shubham, S.; Kumar, S. J. Org. Chem, 2014, 79, 2944-2954. (e) Cuthbertson, J.; Gray, V. J.; Wilden, J. D. Chem. Commun., 2014, 50, 2575-2578. (f) Zhou, S.; Doni, E.; Anderson, G. M.; Kane, R. G.; MacDougall, S. W.; Ironmonger, V. M.; Tuttle T.; Murphy, J. A. J. Am. Chem. Soc. 2014, 136, 17818-17826. (g) Ghosh, D.; Lee, J.-Y.; Liu, C.-Y.; Chiang, Y.-H.; Lee, H. M. Adv. Synth. Catal. 2014, 356, 406-410. (h) Zheng, X.; Yang, L.; Du, W.; Ding, A.; Guo, H. Chem.-Asian J. 2014, 9, 439-442. Bhakuni, B. S.; Yadav, A.; Kumar, S.; Kumar, S. New J. Chem. 2014, 38, 827-836.

(6) (a) Liu, W; Xu, L. G. Tetrahedron 2015, 71, 4974-4981. (b) Liu, W.; Liu, R.; Bi, Y. Tetrahedron 2015, 71, 2622-2628. (c) Doni, E.; Zhou, S.; Murphy, J. A. Molecules, 2015, 20, 1755-1774. (d) Masters, K.-S. RSC Advances 2015, 5, 29975-29986. (e) Yi, H.; Jutand, A.; Lei, A. Chem Commun. 2015, 51, 545-548.(f) A.; Kumar, S.; Kumar, S. New J. Chem. 2014, 38, 827-836. (g) Toutov, A. A.; Liu, W.-B.; Betz, K. N.; Fedorov, A.; Stoltz, B. 
M.; Grubbs, R. H. Nature 2015, 518, 80-84. (h) Drapeau, M. P.; Fabre, I.; Grimaud, L.; Ciofini, I.; Ollevier, T.; Taillefer, M. Angew. Chem. Int. Ed. 2015, 54, 10587-10591.

(7) (a) Patil, M. J. Org. Chem, 2016, 81, 632-639. (b) Ragno, D.; Zaghi, A.; Di Carmine, G.; Giovannini, P. P.; Bortolini, O.; Fogagnolo, M.; Molinari, A.; Venturini, A.; Massi, A. Org. Biomol. Chem., 2016, 14, 9823-9835. (c) For a series of unusual transformations, see Chen, J. H.; Chen, Z.-C.; Zhao, H.; Zou, Y.; Zhang, X.-J.; Yan, M. Org. Biomol. Chem., 2016, 14, 1114811153 and references therein (d) Barham, J. P.; Coulthard, G.; Kane, R. G.; Delgado, N.; John, M. P.; Murphy, J. A. Angew. Chem. Int. Ed., 2016, 55, 4492-4496. (e) Barham, J. P.; Coulthard, G.; Emery, K. J.; Doni, E.; Cumine, F.; Nocera, G.; John, M. P.; Berlouis, L. E. A.; McGuire, T.; Tuttle, T.; Murphy, J. A. J. Am. Chem. Soc. 2016, 138, 7402-7410.

(8) (a) Liu, W; Hou, F; Tetrahedron , 2017, 73, 931-937. (b) Buden, M. E.; Bardagí, J. I.; Puiatti, M.; Rossi, R. A, J. Org. Chem. 2017, 82, 8325-8333. (c) Zhao,H.; Shen, J. Ren, C.; Zeng,W.; Zeng, H. Org. Lett. 2017, 19, 2190-2193 (d) Liu, Y.; Xu, Z.; Zhang, J.; Xu,X.; Jin, Z. Org. Lett. 2017, 19, 5709-5712 (e) Guo, Z.; Li, M.; Mou, X.-Q.;He, G.; Xue,X.-S., Chen, C. Org. Lett. 2018, 20, 1684-1687. (f) Zhang,Y.; Wu, X.; Hao, L.; Wong, Z. R.; Lauw, S. J. L.; Yang,S.; Webster, R. D.; Chi, Y. R. Org. Chem. Front., 2017, 4, 467-471. (g) Cumine, F.; Zhou, S.; Tuttle.T.; Murphy, J. A. Org. Biomol. Chem., 2017, 15, 3324-3336. (h) Emery, K. J.; Tuttle, T.; Murphy, J. A. Org. Biomol. Chem., 2017, 15, 8810-8819. (i) Caminos, D. A.; Puiatti, M.; Bardag1, J. I.; Penenory, A. B. RSC Adv., 2017, 7, 31148-31157. (j) Ahmed, J.; Sreejyothi, P.; Vijaykumar, G.; Jose, A.; Rajb, M.. Mandal S. K. Chem. Sci., 2017, 8, 7798-7806; (k) Chen, Z.-Y.; Wu, L. Y.; Fang, H.-S.; Zhang, T.; Mao, Z.-F.; Zou, Y.; Zhang, X.-J.; Ming Yan, M. Adv. Synth. Catal. 2017, 359, 3894-3899; (1) Chen, J.; Wu, J. Angew. Chem. Int. Ed. 2017, 56, 3951-3955. (m) Zhang, L.; Jiao, L., J. Am. Chem. Soc. 2017, 139, 607-610. (n) Liu, W. B.; Schuman, D. P.; Yang, Y. F.; Toutov, A. A.; Liang, Y.; Klare, H. F. T.; Nesnas,N.; Oestreich,M.; Blackmond, D. G.; Virgil,S. C.; Banerjee,S.; Zare,R. N.; Grubbs, R. H.; Houk, K. N.; Stoltz, B. M. J. Am. Chem. Soc. 2017, 139, 6867-6879 (o) Schuman, D. P.; Grubbs, R. H.; Stoltz, B. M.; Krenske, E. H.; Houk, K. N.; Zare, R. N. J. Am. Chem. Soc. 2017, 139, 6880-6887. (p) Evoniuk, C. J.; dos Passos Gomes, G.; Hill, S. P.; Fujita, S.; Hanson, K.; Alabugin, I. V.; J. Am. Chem. Soc. 2017, 139, 16210-16221; (q) Lin, S.; He, X.; Meng, J.; Gu, H.; Zhang, P.; Wu, J.Eur. J. Org. Chem. 2017, 443-447. (r) Poonpatana, P.; dos Passos Gomes, G.; Hurrle, T.; Chardon, K.; Brase, S.; Masters, K.-S.; Alabugin, , I. Chem. Eur. J. 2017, 23, 9091-9097. (s) Sattar, M.; Rathore, V.; Prasad, C. D.; Kum. S. Chem. Asian J. 2017, 12, 734-743. (t) Smith, A. J. Young, A.; Rohrbach, S.; O’Connor, E. F.; Allison, M.; Wang, H.-S.; Poole, D. L.; Tuttle,T.; Murphy, J. A. Angew. Chem. Int. Ed. 2017, 56, 13747-13751. (w) Yang, H.; Zhang, L.; Jiao, L. Chem. Eur. J. 2017, 23, 65-69.

(9) Tintori, G.; Nabokoff, P. Buhaibeh, R.; Berg-Lefranc, D.; Redon, S. Broggi, J.; Vanelle, P. Angew. Chem. Int. Ed. 2018, 57, 31483153.

(10) Studer, A.; Curran, D. P. Angew. Chem. Int. Ed. 2011, 50, $5018-5022$

(11) (a) Russell, G. A.; Janzen, E. G.; Strom, E. T. J. Am. Chem. Soc. 1962, 84, 4155-4157. (b) Screttas, C. G.; Cazianis, C. T. Tetrahedron 1977, 34, 933-948.

(12) (a) Ashby, E. C.; Goel, A. B.; Argyropoulos, J. N. Tetrahedron Lett. 1982, 23, 2273-2276. (b) Ashby, E. C.; Argyropoulos, J. N. J. Org. Chem. 1986, 51, 3593-3597. (c) Ashby, E. C. Acc. Chem. Res. 1988, 21, 414-421.

(13) Note that different values are cited: (a) Tsierkezos, N. G., J. Solution Chem. 2007, 36, 1301-1310 gave $E^{\mathrm{o}}=-1.269 \mathrm{~V}$ in DMF $v$ s. $\mathrm{Ag} / \mathrm{AgCl}$ (b) Jensen, B. S.; Parker, V. D. J. C. S. Chem. Comm., 1974, 367-368. $E^{\mathrm{o}}=-1.72 \mathrm{~V}$ in DMF vs. SCE with $\mathrm{Me}_{4} \mathrm{NBr}$ as electrolyte. (c) Connelly, N. G.; Geiger, W. E. $E^{0}=-2.2 \mathrm{~V}$ for the [benzophenone] $\rightarrow$ [benzophenone radical anion] couple.

(14) These reactions are quite distinct from the reduction of benzophenone carried out by $\mathrm{KO} t \mathrm{Bu}$ in the presence of hydrogen gas: (a) Walling, C.; Bollyky, L. J. Am. Chem. Soc. 1964, 86, 3750-3752; (b) Walling, C.; Bollyky, L. J. Am. Chem. Soc.1961, 83, 2968-2969. (c) Berkessel, A.; Thomas J. S. Schubert, T. J. S.; Mueller, T. N.; J. Am. Chem. Soc. 2002, 124, 8693-8698.

(15) Cahard, E.; Schoenebeck, F.; Garnier, J.; Cutulic, S. P. Y.; Zhou, S.; Murphy, J. A Angew. Chem. Int. Ed. 2012, 51, $3673-3676$. (b) Mohan M., Murphy, J. A.; LeStrat, F.; Wessel, H. P. Beilstein J. Org. Chem. 2009, 5, No. 1. doi:1.3762/bjoc.5.1. (c) Murphy, J. A. J. Org. Chem. 2014, 79, 3731-3746.

(16) We attribute the non-zero value of the blank reactions to traces of transition metals, no matter how small, that are likely to be present in some reagents that could produce very small amounts of products. The underlines the importance of conducting our blank experiments. See Arvela, R. K.; Leadbeater, N. E.; Sangi, M. S.; Williams, V. A.; Granados, P.; Singer, R. D., J. Org. Chem. 2005 , $70,161-168$.

(17) Scott, T. A.; Ooro, B. A.; Collins, D. J.; Shatruk, M.; Yakovenko, A.; Dunbar, K. R.; Zhou, H.-C. Chem. Commun. 2009, 65-67.

(18) Anderson, G. M.; Cameron, I.; Murphy, J. A.; Tuttle, T., RSC $A d v$. 2016, 6, 11335-11343.

(19) GaussSum software was used to reproduce the UV-vis spectra: O'Boyle, N. M.; Tenderholt, A. L.; Langner. K. M. J. Comp. Chem. 2008, 29, 839-845.

(20) Walling, C.; Jacknow, B. B. J. Am. Chem. Soc. 1960, 82, 61086112. (b) Griller, D.; Ingold, K. U. Acc. Chem. Res. 1980, 13, $317-332$.

(21) Unique peaks were detected and their elemental composition assigned in the methylation or ethylation experiments by HRMS (EI): (a) methylation experiment: methylbenzophenone $\mathrm{C}_{14} \mathrm{H}_{12} \mathrm{O}$ (m/z 196.0893, calc. 196.0888); (b) ethylation experiment, ethylbenzophenone $\mathrm{C}_{15} \mathrm{H}_{14} \mathrm{O}(\mathrm{m} / z$ 210.1052, calc. 210.1045).

(22) This paper illustrates the differential effects of alkali metal cations $\mathrm{Na}^{+}$and $\mathrm{K}^{+}$in their butoxides. Building on the roles of alkali metal salts in organic synthesis, recent studies by the Chiba group illustrate the effect of anionic additives on the reactivity of $\mathrm{NaH}$. (a) Too, P. C.; Chan, G. H.; Tnay, Y. L.; Hirao, H.; Chiba, S; Angew. Chem. Int. Ed. 2016, 55, 3719 -3723. (b) Hong, Z.; Ong, D. Y.; Muduli, S. K.; Too, P. C.; Chan, G. H.; Tnay, Y. L.; Chiba, S.; Nishiyama, Y.; Hirao, H.; Soo, H. S. Chem. Eur. J. 2016, 22, 7108-7114. (c) Ong, D. Y.; Tejo, C.; Xu, K.; Hirao, H.; Chiba, S. Angew. Chem. Int. Ed. 2017, 56, 1840 -1844. Huang, Y.; Chan, G. H.; Chiba, S. Angew. Chem. Int. Ed. 2017, 56, 6544 6547.

(23) (a) Hoffmann, N. Chem. Rev. 2008, 108, 1052-1103. (b) Dormán, G.; Nakamura, H.; Pulsipher, A.; Prestwich, G. D. Chem. Rev. 2016, 116, 15284-15398. (c) Wagner, P. J. In Triplet States III; Springer Berlin Heidelberg: Berlin, Heidelberg, 1976; pp 1-52.

(24) (a) Singh, M.; Yadav, a. K.; Yadav, L. D. S.; Singh, R. K. P. Tetrahedron Lett., 2017, 58, 2206-2208. (b) Xia, J.-B.; Zhu, C.; Chen, C. J. Am. Chem. Soc. 2013, 135, 17494-17500.

(25) Dai, P.; Ma, J.; Huang, W.; Chen, W.; Wu, N.; Wu, S.; Li, Y.; Cheng, X.; Tan, R. ACS Catal. 2018, 8, 802-806.

(26) (a) Bahamonde, A.; Melchiorre, P. J. Am. Chem. Soc. 2016, 138, 8019-8030. (b) Silvi, M.; Melchiorre, P. Nature, 2018, 554, 4149.

(27) Marzo, L.; Pagire, S. K.; Reiser, O.; König, B., Angew. Chem. Int. Ed. 2018, 57, 10.1002/anie.201709766. 
TOC Graphic

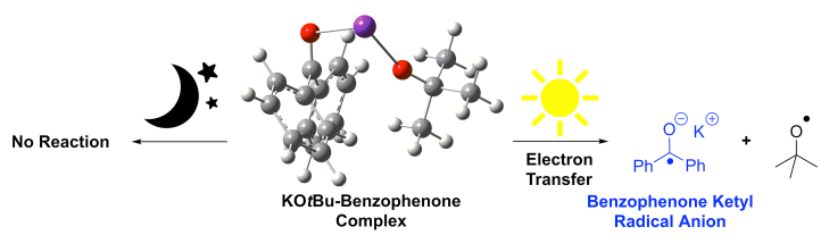




\section{Electron Transfer Reactions: KOtBu (but not NaOtBu) Photo-reduces Benzophenone, under} Activation by Visible Light

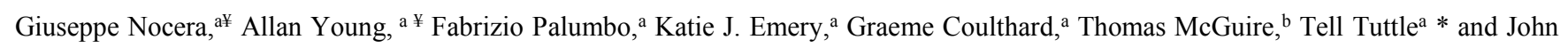
A. Murphy ${ }^{a} *$

aDepartment of Pure and Applied Chemistry, University of Strathclyde, 295 Cathedral Street, Glasgow, G1 1XL, U.K.

bOncology, IMED Biotech Unit, AstraZeneca, Building 310, Cambridge Science Park, 319 Milton Road, Cambridge CB4 0WG, U.K.

Table of contents

General information

Preparation of substrates

Qualitative evaluation of the formation of ketyl radicals of aromatic ketones

LED calibration

Methylation and ethylation of benzophenone

UV measurements

NMR tests throughout the reaction

Cross coupling reaction

NMR spectra

Computational Results

XYZ Coordinates of Optimised Geometries

References

\section{Page}

S2

S2-S5

S6

S7-S8

S8-S11

S12-S14

S15-S16

S17-S22

S23-S32

S33-S35

S36-S114

S115 


\section{General information}

All reagents were purchased from commercial sources and used without further purification, except where stated. Anhydrous diethyl ether, tetrahydrofuran, dichloromethane and hexane were dried using a Pure-Solv 400 solvent purification system (Innovative Technology Inc., U.S.A.). Tetrahydrofuran was further distilled over sodium "wire" using benzophenone as indicator using a still. The distilled THF was used for all the ketyl radical development. Anhydrous benzene was purchased from Sigma Aldrich and dried over $3 \AA$ molecular sieves, previously activated by microwave heating. Thin layer chromatography analyses were carried out on silica gel pre-coated aluminum foil sheets and were visualized using UV light $(254 \mathrm{~nm})$. Flash column chromatography was carried out using slurry packed silica gel $\left(\mathrm{SiO}_{2}\right)$, 35-75 $\mu \mathrm{m}$ particle size, $60 \AA$ pore size, under a light positive pressure, eluting with the specified solvent system.

Where reactions were carried out in a glovebox, the atmosphere used was nitrogen and the glovebox was supplied by Innovative Technology Inc., USA. ${ }^{1} \mathrm{H}-\mathrm{NMR},{ }^{2} \mathrm{H}-\mathrm{NMR}$ and ${ }^{13} \mathrm{C}-\mathrm{NMR}$ spectra were recorded on spectrometers operating at $400 \mathrm{MHz}, 61 \mathrm{MHz}$ and 101 $\mathrm{MHz}$, respectively. All spectral data were acquired at $295 \mathrm{~K}$. Chemical shifts $(\delta)$ are quoted in parts per million (ppm). Coupling constants $(J)$ are reported in Hertz $(\mathrm{Hz})$ to the nearest $0.1 \mathrm{~Hz}$. The multiplicity abbreviations used are: s (singlet), d (doublet), $\mathrm{t}$ (triplet), q (quartet), qn (quintet), sextet (st), m (multiplet). Infrared (IR) spectra were recorded using an FTIR-ATR spectrometer. High resolution mass spectrometry was performed at the University of Swansea, in the EPSRC National Mass Spectrometry Centre. Accurate mass was obtained using a LTQ Orbitrap XL using Atmospheric Pressure Chemical Ionization (APCI) or High Resolution Nano-Electrospray (HNESP) using Electrospray Ionization (ESI). The mass spectra were recorded by gas-phase chromatography (GCMS) using electron ionization (EI). Low resolution GCMS data were recorded using an Agilent Technologies 7890A GC system coupled to a 5975C inert XL EI/CI MSD detector. Separation was performed using the DB5MS-UI column $(30 \mathrm{~m} \times 0.25 \mathrm{~mm} \times 0.25 \mu \mathrm{m})$ at a temperature of $320^{\circ} \mathrm{C}$, using helium as the carrier gas.

All the UV reactions were carried out by using two focused UV lamps with filters ( $\lambda=365 \mathrm{~nm}$, each 100 watts $)$ placed opposite to each other, around the reaction flask, at room temperature. All the Vis light reactions were carried out by using 60 LEDs in series (400 nm, 14.4 $\mathrm{W}$ total, SMD5050). The series internally lined a beaker and the reaction tubes were placed centrally in the beaker (2-3 cm of distance from the LEDs). When stated, the reactions were performed in direct sunlight. The 'dark' reactions were performed by covering the tube in foil to avoid any light exposure.

UV-visible absorption measurements were performed using a PerkinElmer Lambda 25 UV/VIS spectrophotometer.

Calculations of the yields of reactions using the internal standard 1,3,5-trimethoxybenzene $\left({ }^{1} \mathrm{H}-\mathrm{NMR}\right.$ internal standard $)$ were performed as follows: 1,3,5-trimethoxybenzene $(8.4 \mathrm{mg}, 0.050 \mathrm{mmol}, 10 \mathrm{~mol} \%)$ was added as a solid to the reaction mixture. $\mathrm{CDCl}_{3}(\sim 1 \mathrm{~mL})$ was added and the solution stirred for $5 \mathrm{~min}$. A portion of the solution was taken and diluted for NMR analysis.

\section{Preparation of the substrates}

\section{4,4'-Di-tert-butylbenzophenone, 27}

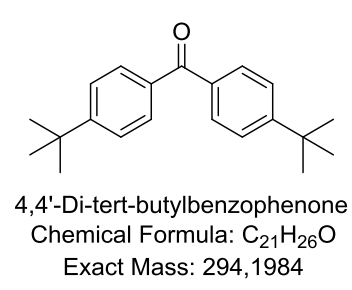

p-tert-Butylbenzoyl chloride $(1.18 \mathrm{~g}, 1.17 \mathrm{ml}, 6 \mathrm{mmol})$ was slowly added to tert-butylbenzene ( $1.93 \mathrm{mg}, 2.22 \mathrm{~mL}, 14.4 \mathrm{mmol})$ and aluminium trichloride $(2.22 \mathrm{~g}, 15.2 \mathrm{mmol})$ at RT. During the addition of $p$-tert-butylbenzoyl chloride, the reaction turned from a yellow suspension to a dark reddish brown solution. After the addition was complete, the reaction was warmed at $80{ }^{\circ} \mathrm{C}$ for $2.5 \mathrm{~h}$. Vigorous bubbling was observed throughout the reaction. Afterwards, the hot reaction mixture was poured into crushed ice (30 g) and concentrated hydrochloric acid $(10.5 \mathrm{~mL})$. This yielded a tar-like substance which metamorphosed to a yellow solid after decomposition was complete (few minutes). This yellow solid was filtered, dissolved in toluene $(15 \mathrm{~mL})$, washed with water and $5 \%$ aqueous sodium hydroxide and dried over sodium sulfate. Recrystallisation from toluene produced a white powder which was washed with hexane to give 27 as a white solid (625 mg, $0.68 \mathrm{mmol}, 35.5 \%) .{ }^{1} \mathrm{Mp}: 122-124{ }^{\circ} \mathrm{C}\left(\mathrm{lit}: 123-124^{\circ} \mathrm{C}\right) .{ }^{2} v_{\max }$ (neat, $\left.\mathrm{cm}^{-1}\right)$ 2959, 2903, 2864, 1643, 1605, 1280, 1186, 1104, 932. ${ }^{1} \mathrm{H}-\mathrm{NMR}\left(400 \mathrm{MHz}, \mathrm{CDCl}_{3}\right) \delta 7.76(4 \mathrm{H}, \mathrm{d}, J=8.6, \mathrm{Ar} H), 7.49(4 \mathrm{H}, \mathrm{d}, J=8.8, \mathrm{Ar} H), 1.37(18 \mathrm{H}, \mathrm{s}, \mathrm{CH}) \mathrm{ppm} .{ }^{13} \mathrm{C}-\mathrm{NMR}(101$ $\left.\mathrm{MHz}_{2} \mathrm{CDCl}_{3}\right) \delta 195.7,155.4,134.7,129.5,124.7,34.6,30.7 \mathrm{ppm}$. GC-MS (EI) $\mathrm{m} / z$ 294.1. Data were consistent with the literature. ${ }^{1}$

\section{Dimesitylmethanol, 38}

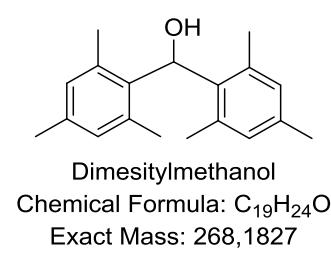

To a cooled $\left(-78{ }^{\circ} \mathrm{C}\right)$ solution of mesityllithium, prepared by addition of $n$-butyllithium $(2.2 \mathrm{mmol})$ to a solution of mesityl bromide (478 $\mathrm{mg}, 0.37 \mathrm{~mL}, 2.4 \mathrm{mmol})$ in $8 \mathrm{~mL}$ of THF, a solution of mesitylaldehyde (296 mg, $0.294 \mathrm{~mL}, 2.0 \mathrm{mmol})$ in $2 \mathrm{~mL}$ of THF. After $30 \mathrm{~min}$, the solution was allowed to warm and was quenched with aqueous ammonium chloride. The product was extracted with diethyl ether, dried over sodium sulfate and concentrated. The crude was washed with pentane to give dimesitylmethanol $\mathbf{3 8}$ as a white solid (315 mg, 1.18 
mol, 59\%). Mp: 145-147 (lit: 149-150 $\left.{ }^{\circ} \mathrm{C}\right)^{3} \mathrm{IR} v_{\max }\left(\right.$ neat, $\left.\mathrm{cm}^{-1}\right)$ 3472, 2908, 1608, 1476, 1420, 1375, 1126, 1045, 1003, 851, 694. ${ }^{1} \mathrm{H}-\mathrm{NMR}$ $\left(400 \mathrm{MHz}, \mathrm{CDCl}_{3}\right) \delta 6.82-6.78(4 \mathrm{H}, \mathrm{s}, \mathrm{ArH}), 6.37-6.33(1 \mathrm{H}, \mathrm{s}, \mathrm{CHOH}), 2.27-2.24(6 \mathrm{H}, \mathrm{s}, \mathrm{CH}), 2.23-2.19(12 \mathrm{H}, \mathrm{s}, \mathrm{CH}), 1.73-1.68(1$ $\mathrm{H}, \mathrm{s}, \mathrm{OH}) \mathrm{ppm} .{ }^{13} \mathrm{C}-\mathrm{NMR}\left(101 \mathrm{MHz}, \mathrm{CDCl}_{3}\right) \delta 136.7,130.7,73.5,21.2,20.8 \mathrm{ppm} .{ }^{4} \mathrm{GC}-\mathrm{MS}(\mathrm{EI}) \mathrm{m} / z$ 268.1. Data were consistent with the literature. ${ }^{4}$

\section{Dimesitylmethanone, 28}

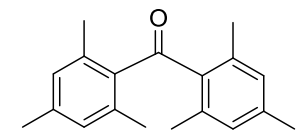

Dimesitylmethanone

Chemical Formula: $\mathrm{C}_{19} \mathrm{H}_{22} \mathrm{O}$

Exact Mass: 266,1671

Pyridinium chlorochromate $(2.53 \mathrm{~g}, 11.8 \mathrm{mmol})$ was added to a solution of dimesitylmethanol $38(2.10 \mathrm{~g}, 7.8 \mathrm{mmol})$ in $35 \mathrm{~mL}$ of DCM and allowed to stir at RT for $3 \mathrm{~h}$. The crude product was filtered on a celite pad, the solution concentrated and crystallised from methanol to give dimesitylmethanone, 28 as a white solid $(1.4 \mathrm{~g}, 5.2 \mathrm{mmol}, 67 \%) .{ }^{4} \mathrm{Mp}: 140-143{ }^{\circ} \mathrm{C}$ (lit: $\left.138-140{ }^{\circ} \mathrm{C}\right)^{4}$. IR $v_{\max }\left(\mathrm{neat}, \mathrm{cm}^{-1}\right) 2916$, 1643, 1605, 1422, 1242, 887, 855, 696. ${ }^{1} \mathrm{H}-\mathrm{NMR}\left(400 \mathrm{MHz}^{\mathrm{CDCl}} \mathrm{CD}_{3}\right) 6.84(4 \mathrm{H}, \mathrm{s}, \mathrm{ArH}), 2.29(6 \mathrm{H}, \mathrm{s}, \mathrm{CH}), 2.12(12 \mathrm{H}, \mathrm{s}, \mathrm{CH}) \mathrm{ppm}$. ${ }^{13} \mathrm{C}-\mathrm{NMR}\left(101 \mathrm{MHz}, \mathrm{CDCl}_{3}\right) \delta 202.8,140.1,138.6,136.8,129.9$ 21.3, 20.9 ppm. GC-MS (EI) m/z $266.1\left(\mathrm{M}^{+}\right)$.

\section{(2,4-Dichloro-6-hydroxyphenyl)(2,4,6-trichlorophenyl)methanone, 39}

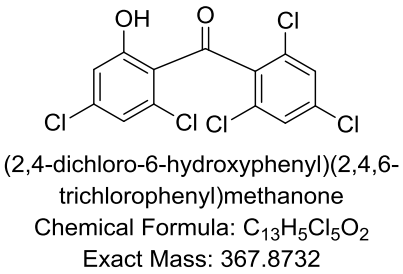

3,5-Dichloroanisole $(2.8 \mathrm{mg}, 16 \mathrm{mmol})$ and aluminium chloride $(2.55 \mathrm{~g}, 19.2 \mathrm{mmol})$ were cooled to $0{ }^{\circ} \mathrm{C}$ in a flask under inert atmosphere. 2,4,6-Trichlorobenzoyl chloride $(4.65 \mathrm{~g}, 19.2 \mathrm{mmol})$ was then added and the reaction mixture was stirred at $110^{\circ} \mathrm{C}$ for $15 \mathrm{~h}$. At the end of the reaction (monitored by TLC), water $(15 \mathrm{~mL})$ was added and the mixture stirred. The mixture was extracted with ethyl acetate, dried over sodium sulfate and concentrated in vacuo. Purification with silica gel chromatography (hexane) afforded (2,4-dichloro-6hydroxyphenyl)(2,4,6-trichlorophenyl)methanone, $39(1.7 \mathrm{~g}, 4.69 \mathrm{mmol}, 58.6 \%)$ as a white solid. Mp: $82-84{ }^{\circ} \mathrm{C}$. IR $v_{\max }\left(\mathrm{neat}, \mathrm{cm}^{-1}\right) 1626$, $1543,1386,1365,1298,1224,1184,1089,960,916 .{ }^{1} \mathrm{H}$ NMR $\left(400 \mathrm{MHz} \mathrm{CDCl}_{3}\right) \delta 12.58(1 \mathrm{H}, \mathrm{s}, \mathrm{OH}), 7.38(2 \mathrm{H}, \mathrm{s}, \mathrm{ArH}), 7.06(1 \mathrm{H}, \mathrm{d}, J$ $=2.1, \mathrm{Ar} H), 6.96(1 \mathrm{H}, \mathrm{d}, J=2.1, \mathrm{Ar} H) \mathrm{ppm} .{ }^{13} \mathrm{C} \mathrm{NMR}\left(101 \mathrm{MHz}, \mathrm{CDCl}_{3}\right) \delta 195.7,165.9,143.0,137.8,136.6,136.44,132.2,128.5$, 123.0, 118.4, 117.0 ppm. $m / z$ (APCI) calcd. for $\mathrm{C}_{13} \mathrm{H}_{6} \mathrm{Cl}_{5} \mathrm{O}_{2}[\mathrm{M}+\mathrm{H}]^{+}: 368.8805$, found: 368.8798 .

\section{3,5-Dichloro-2-(2,4,6-trichlorobenzoyl)phenyl trifluoromethanesulfonate, 40}

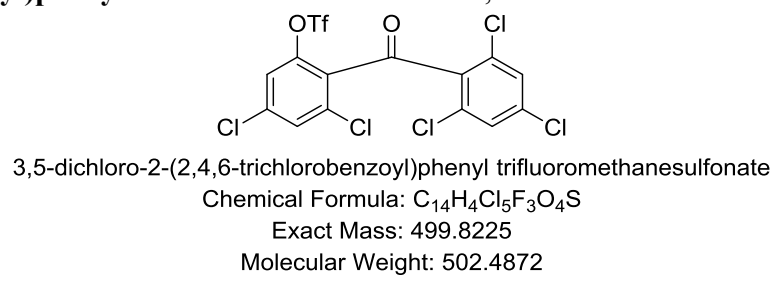

Ketone 39 (1.61 g, 4,4 mmol), anhydrous DCM $(8 \mathrm{~mL})$ and pyridine $(695.2 \mathrm{mg}, 8,8 \mathrm{mmol})$ were added to a round-bottomed flask, under argon atmosphere. The mixture was cooled to $0^{\circ} \mathrm{C}$ in an ice bath, then was treated with dropwise addition of triflic anhydride (4.49 $\mathrm{g}, 5.28$ $\mathrm{mmol})$. The resulting mixture was allowed to warm up to RT and kept stirred for additional $4 \mathrm{~h}$. The mixture was then filtered and concentrated in vacuo. The product was purified by chromatography (hexane), affording 40 (1.24 g, 2.48 mmol, 56.4 \%). Mp: $110-112{ }^{\circ} \mathrm{C}$. IR $v_{\max }\left(\right.$ neat, $\left.\mathrm{cm}^{-1}\right) 1686,1427,1207,1136,1091,953,910,798 .{ }^{1} \mathrm{H}$ NMR $\left(400 \mathrm{MHz} \mathrm{CDCl}_{3}\right) \delta 7.46(1 \mathrm{H}, \mathrm{d}, J=1.9, \mathrm{Ar} H), 7.40-7.36(3$ $\mathrm{H}, \mathrm{m}, \mathrm{Ar} H) \mathrm{ppm} .{ }^{13} \mathrm{C} \mathrm{NMR}\left(101 \mathrm{MHz}, \mathrm{CDCl}_{3}\right) \delta \mathrm{ppm} 185.8,148.5,138.8,137.9,134.9,134.6,134.5,130.4,129.3,121.5,118.5(\mathrm{q}, J=$ 320.6, $\left.\mathrm{CF}_{3}\right)$ ppm. $\mathrm{m} / \mathrm{z}$ (APCI) calcd. for $\mathrm{C}_{14} \mathrm{H}_{5} \mathrm{Cl}_{5} \mathrm{~F}_{3} \mathrm{O}_{4} \mathrm{~S}[\mathrm{M}+\mathrm{H}]^{+}:$500.8298, found: 500.8287.

\section{Bis(5'-phenyl-[1,1':3',1'-terphenyl]-2'-yl)methanone, 30}

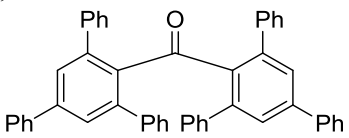

bis(5'-phenyl-[1,1':3',1"-terphenyl]-2'-yl)methanone

Chemical Formula: $\mathrm{C}_{49} \mathrm{H}_{34} \mathrm{O}$

Exact Mass: 638.2610

Molecular Weight: 638.8100

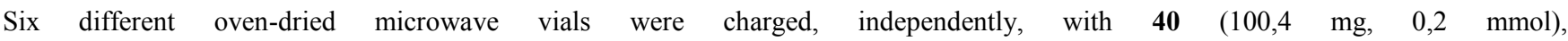
bis(acetonitrile)dichloropalladium(II) (2,6 mg, 0,01 mmol, 5\%), Sphos (8,2 mg, 0,02 mmol, 10 \%), phenylboric acid (292,8 mg, 2,4 mmol) 
and $\mathrm{K}_{3} \mathrm{PO}_{4}(508,8 \mathrm{mg}, 2,4 \mathrm{mmol})$. The mixture was then introduced into the glovebox and anhydrous toluene $(10 \mathrm{~mL})$ was added. The vial was then sealed inside the glovebox and transferred into the fumehood, where it was heated at $110{ }^{\circ} \mathrm{C}$ for 4 days. The six cooled reaction mixtures were then combined and diluted with water and extracted with toluene. The combined organic layers were combined, dried over sodium sulfate, filtered and concentrated in vacuo. The residue was purified by chromatography (hexane) affording a white solid which was recrystallised using a small amounts of toluene (very soluble) and hexane (almost insoluble) giving rise to ketone $\mathbf{3 0}$ (454 mg, 0.71 mmol, 59.3\% combined yield from the 6 vials). The reaction was found to work better in a system under pressure such as a microwave vial. A bigger scale in a normal three-necked flask was tried, but only traces of product were detected. ${ }^{5} \mathrm{Mp}: 246-248{ }^{\circ} \mathrm{C}$. IR $v_{\max }\left(\mathrm{neat}\right.$, $\mathrm{cm}^{-}$ 1) $3053,1665,1590,1491,1229,1074,1029 .{ }^{1} \mathrm{H}$ NMR $\left(400 \mathrm{MHz} \mathrm{CDCl}_{3}\right) \delta 7.52-7.48(4 \mathrm{H}, \mathrm{m}, \mathrm{ArH}), 7.43(4 \mathrm{H}, \mathrm{t}, J=7.3, \mathrm{Ar} H), 7.39-$ $7.35(2 \mathrm{H}, \mathrm{m}, \mathrm{Ar} H), 7.33-7.26(12 \mathrm{H}, \mathrm{m}, \mathrm{Ar} H), 7.20-7.17(8 \mathrm{H}, \mathrm{m}, \mathrm{Ar} H), 7.09(4 \mathrm{H}, \mathrm{s}, \mathrm{Ar} H) \mathrm{ppm} .{ }^{13} \mathrm{C} \mathrm{NMR}(101 \mathrm{MHz}, \mathrm{CDCl} 3) \delta 193.7$, $143.4,141.2,140.9,139.4,136.2,129.8,128.7,128.3,127.3,126.7,126.7,126.2$ ppm. $m / z$ (APCI) calcd. for $\mathrm{C}_{49} \mathrm{H}_{35} \mathrm{O}[\mathrm{M}+\mathrm{H}]^{+}: 639.2682$, found: 639.2678 .

\title{
(2,4-Dichloro-6-hydroxyphenyl)(2,6-dichlorophenyl)methanone, 41
}

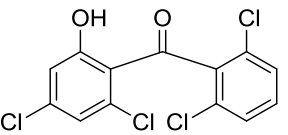 \\ (2,4-dichloro-6-hydroxyphenyl)(2,6-dichlorophenyl)methanone \\ Chemical Formula: $\mathrm{C}_{13} \mathrm{H}_{6} \mathrm{Cl}_{4} \mathrm{O}_{2}$ \\ Exact Mass: 333.9122 \\ Molecular Weight: 335.9890
}

Aluminium chloride $(1.8 \mathrm{~g}, 13.2 \mathrm{mmol})$ and 3,5-dichloroanisole $(1.0 \mathrm{~g}, 6 \mathrm{mmol})$ were added to a flask under inert atmosphere and this was then cooled at $0{ }^{\circ} \mathrm{C}$. 2,6-Dichlorobenzoyl chloride $(1.5 \mathrm{~g} \mathrm{mg}, 7.2 \mathrm{mmol})$ was then added. The reaction mixture was stirred at $110^{\circ} \mathrm{C}$ for 15 h. The mixture was extracted with ethyl acetate, dried over sodium sulfate and concentrated in vacuo. Purification with silica gel chromatography using pure hexane as eluent afforded $41\left(1.91 \mathrm{~g}, 5.72 \mathrm{mmol}, 72 \%\right.$ yield). $\mathrm{Mp}: 98-100{ }^{\circ} \mathrm{C}$. IR $v_{\max }\left(\mathrm{neat}, \mathrm{cm}^{-1}\right) 3080$, $1618,1593,1545,1425,1396,1296,1223,1175,956,912,846,804 .{ }^{1} \mathrm{H} \mathrm{NMR}\left(400 \mathrm{MHz} \mathrm{CDCl}_{3}\right) \delta 12.70(1 \mathrm{H}, \mathrm{s}, \mathrm{OH}), 7.37-7.31(3 \mathrm{H}$, m, $\mathrm{Ar} H), 7.05(1 \mathrm{H}, \mathrm{d}, J=2.0, \mathrm{Ar} H), 6.94(1 \mathrm{H}, \mathrm{d}, J=2.1, \mathrm{Ar} H) \mathrm{ppm} .{ }^{13} \mathrm{C} \mathrm{NMR}\left(101 \mathrm{MHz}, \mathrm{CDCl}_{3}\right) \delta 196.0,165.3,142.1,138.5,136.1$, $131.2,130.9,130.5,127.7,122.3,120.3,117.6,116.5$ pm. $\mathrm{m} / z$ (APCI) calcd. for $\mathrm{C}_{13} \mathrm{H}_{7} \mathrm{Cl}_{4} \mathrm{O}_{2}[\mathrm{M}+\mathrm{H}]^{+}$: 334.9200, found 334.9209 . Analogous demethylation of anisole using $\mathrm{AlCl}_{3}$ was previously reported in the literature. ${ }^{6}$

\section{3,5-Dichloro-2-(2,6-dichlorobenzoyl)phenyl trifluoromethanesulfonate, 42}

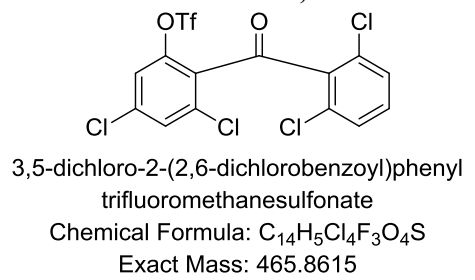

Ketone 41 (1.6 g, $4.8 \mathrm{mmol})$, anhydrous DCM ( $8 \mathrm{~mL})$ and pyridine $(758.4 \mathrm{mg}, 9.6 \mathrm{mmol})$ were added to a round-bottomed flask, under argon atmosphere. The solution was cooled to $0^{\circ} \mathrm{C}$ in an ice bath and then was treated with dropwise addition of triflic anhydride (1.62 g, $5.76 \mathrm{mmol}$ ). The resulting mixture was allowed to warm to RT and stirred for additional $4 \mathrm{~h}$. At the end of the reaction (monitored by TLC), the mixture was filtered and concentrated in vacuo. The product was purified by chromatography (hexane), affording ketone 42 (2.0 g, $4.40 \mathrm{mmol}, 92 \%$ ) as a white solid. Mp: $95-97^{\circ} \mathrm{C}$. IR $v_{\max }$ (neat, $\mathrm{cm}^{-1}$ ) 1690, 1591, 1429, 1211, 1138, 955, 910, 868, 800, 781. ${ }^{1} \mathrm{H} \mathrm{NMR}$ $\left(400 \mathrm{MHz} \mathrm{CDCl}_{3}\right) \delta 7.46(1 \mathrm{H}, \mathrm{d}, J=1.8, \mathrm{Ar} H), 7.38(1 \mathrm{H}, \mathrm{d}, J=1.8, \mathrm{Ar} H), 7.36-7.34(3 \mathrm{H}, \mathrm{m}, \mathrm{Ar} H) \mathrm{ppm} .{ }^{13} \mathrm{C} \mathrm{NMR}\left(101 \mathrm{MHz}, \mathrm{CDCl}_{3}\right)$ $\delta 186.0,147.9,137.9,135.8,134.0,133.2,131.7,129.9,129.7,128.6,120.7,117.9\left(\mathrm{q}, J=320 \mathrm{~Hz}, C \mathrm{~F}_{3}\right) \mathrm{ppm} . \mathrm{m} / z(\mathrm{APCI}) \mathrm{calcd}$. for $\mathrm{C}_{14} \mathrm{H}_{9} \mathrm{Cl}_{4} \mathrm{~F}_{3} \mathrm{NO}_{4} \mathrm{~S}\left[\mathrm{M}+\mathrm{NH}_{4}\right]^{+}: 483.8953$, found 483.8950 .

\section{[1,1':3',1'-Terphenyl]-2'-yl(5'-phenyl-[1,1':3',1'-terphenyl]-2'-yl)methanone, 29

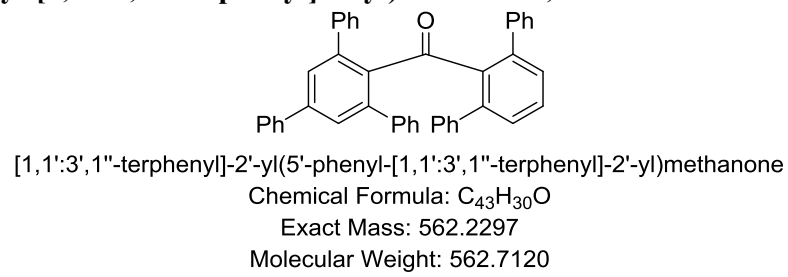

Six oven-dried microwave vials were charged, independently, with ketone 42 (93.6 mg, $0.2 \mathrm{mmol}$ ), bis(acetonitrile)dichloropalladium(II) (2.59 mg, $0.01 \mathrm{mmol}, 5 \%$ ), Sphos ( $8.2 \mathrm{mg}, 0.02 \mathrm{mmol}, 10 \%)$ phenylboronic acid (244 mg, $2 \mathrm{mmol})$ and $\mathrm{K}_{3} \mathrm{PO}_{4}(424 \mathrm{mg}, 2 \mathrm{mmol})$. The mixture was then introduced in the glovebox and anhydrous toluene $(10 \mathrm{~mL})$ was added. The vials were then closed, removed from the glovebox and placed in the fumehood, where they were heated at $110^{\circ} \mathrm{C}$ for 5 days (monitored via NMR). The cooled reaction mixture was diluted with water and extracted with toluene. The combined organic layers were combined, dried over sodium sulfate, filtered and the filtrate was concentrated in vacuo. The mixture was purified via chromatography (hexane : ethyl acetate as $9.5: 0.5$ ), affording the product (420 mg, $0.75 \mathrm{mmol}, 62 \%$ combined yield) as a white powder. The reaction was found to work better in a system under pressure such as a microwave vial. A bigger scale in a normal three-necked flask was tried but only traces of product were detected. Reaction conditions were inspired by prior literature. ${ }^{5} \mathrm{Mp}: 90-93{ }^{\circ} \mathrm{C}$. IR $v_{\max }\left(\right.$ neat $\left./ \mathrm{cm}^{-1}\right) 3048,1667,1589,1491,1231,926,885,756,694 .{ }^{1} \mathrm{H} \mathrm{NMR}(400 \mathrm{MHz}$ 
$\left.\mathrm{CDCl}_{3}\right) \delta 7.51-7.47(2 \mathrm{H}, \mathrm{m}), 7.45-7.39(2 \mathrm{H}, \mathrm{m}), 7.39-7.33(1 \mathrm{H}, \mathrm{m}), 7.33-7.23(13 \mathrm{H}, \mathrm{m}), 7.18-7.13(4 \mathrm{H}, \mathrm{m}), 7.13-7.09(4 \mathrm{H}$, m), $7.06(2 \mathrm{H}, \mathrm{s}), 6.87(2 \mathrm{H}, \mathrm{d}, J=7.6) \mathrm{ppm} .{ }^{13} \mathrm{C} \mathrm{NMR}\left(101 \mathrm{MHz}, \mathrm{CDCl}_{3}\right) \delta 193.9,143.4,142.6,141.1,140.9,140.9,139.4,137.3,135.8$, $130.2,129.8,128.8,128.6,128.30,127.3,126.8,126.7,126.6,126.2,126.0 \mathrm{ppm} . \mathrm{m} / z$ (APCI) calcd. for $\mathrm{C}_{43} \mathrm{H}_{31} \mathrm{O}[\mathrm{M}+\mathrm{H}]^{+}: 563.2375$, found 563.2388 .

\section{Potassium 3-ethylpentan-3-olate, 43}

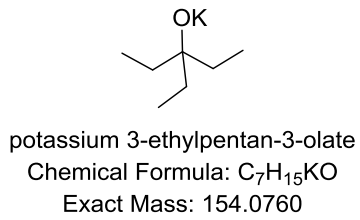

In the glovebox, previously washed potassium hydride $(400 \mathrm{mg}, 10 \mathrm{mmol}$ ) was added to a flame-dried three-necked flask, equipped with a vacuum tap. The flask was then sealed, removed from the glovebox and placed in a $-78{ }^{\circ} \mathrm{C}$ bath in a fumehood. A solution of triethylcarbinol $(1160 \mathrm{mg}, 10 \mathrm{mmol})$ in anhydrous diethyl ether $(20 \mathrm{~mL})$ was added. The reaction mixture was stirred at $-78{ }^{\circ} \mathrm{C}$ for $1 \mathrm{~h}$, then at RT overnight. The solvent was removed on the house vacuum line and the crude material was dried for $3 \mathrm{~h}$, put under an argon atmosphere and transferred into the glove box immediately giving rise to $43(1.3 \mathrm{~g}, 8.4 \mathrm{mmol}, 84 \%)$. ${ }^{1} \mathrm{H} \mathrm{NMR}\left(400 \mathrm{MHz}, \mathrm{C}_{6} \mathrm{D}_{6}\right) \delta 1.22(6$ $\left.\mathrm{H}, \mathrm{q}, J=7.5, \mathrm{CH}_{2} \mathrm{CH}_{3}\right), 0.85\left(9 \mathrm{H}, \mathrm{t}, J=7.5, \mathrm{CH}_{2} \mathrm{CH}_{3}\right) \mathrm{ppm} .{ }^{13} \mathrm{C} \mathrm{NMR}\left(101 \mathrm{MHz}, \mathrm{C}_{6} \mathrm{D}_{6}\right) \delta 71.8,33.1,8.1 \mathrm{ppm}$. 


\section{Qualitative evaluation of formation of ketyl radicals of aromatic ketones}

General procedure for testing the reduction of benzophenone and benzophenone derivatives with $\mathrm{Na}$ or $\mathrm{KO} t \mathrm{Bu}$.<smiles>[R]c1cc([R])c(C(=O)c2c([R])cc([R])cc2[R])c([R])c1</smiles>

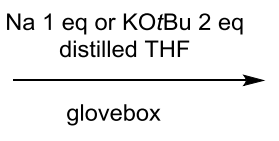<smiles>[R]c1cc([R])c(C(C)[O-])c([R])c1</smiles>

The aromatic ketone ( 1 eq, $0.77 \mathrm{mmol})$ was added to distilled THF $(5 \mathrm{~mL})$ into a pressure tube containing sodium $(18 \mathrm{mg}, 0.77 \mathrm{mmol})$ or KOIBu (172 mg $1.54 \mathrm{mmol})$ in the glovebox. The sealed pressure tube was then removed from the glovebox and placed on a stirrer hotplate in the fumehood. Where specified, the reaction was heated to $70^{\circ} \mathrm{C}$ behind a blast shield. The ketyl radical formation was detected through development of a blue coloration in the solution. The reaction was quenched with isopropyl alcohol and the blue coloration disappeared soon after the addition.

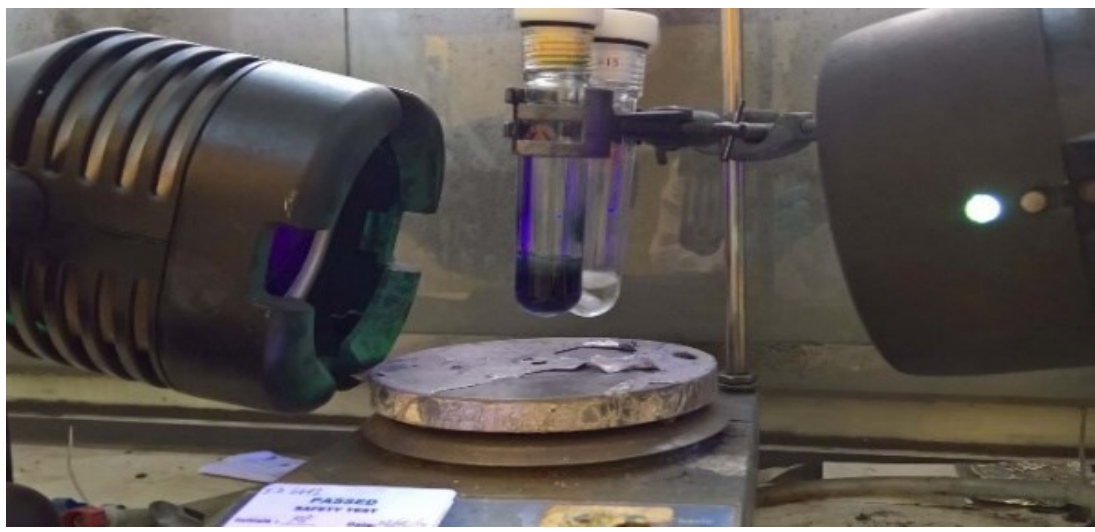

Figure S1 Above is a typical example of reaction performed under UV lamps (365 nm, $100 \mathrm{~W}$ x 2) at RT. Left: THF $+\mathbf{1 7}(0.5 \mathrm{mmol})+\mathrm{KO} t \mathrm{Bu}(2 \mathrm{eq})$. Right: blank reaction THF $+\mathbf{1 7}(0.5 \mathrm{mmol})$. Picture taken after $30 \mathrm{~min}$.

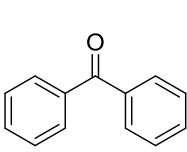

17

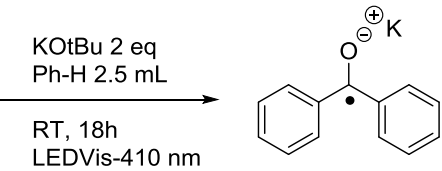

18
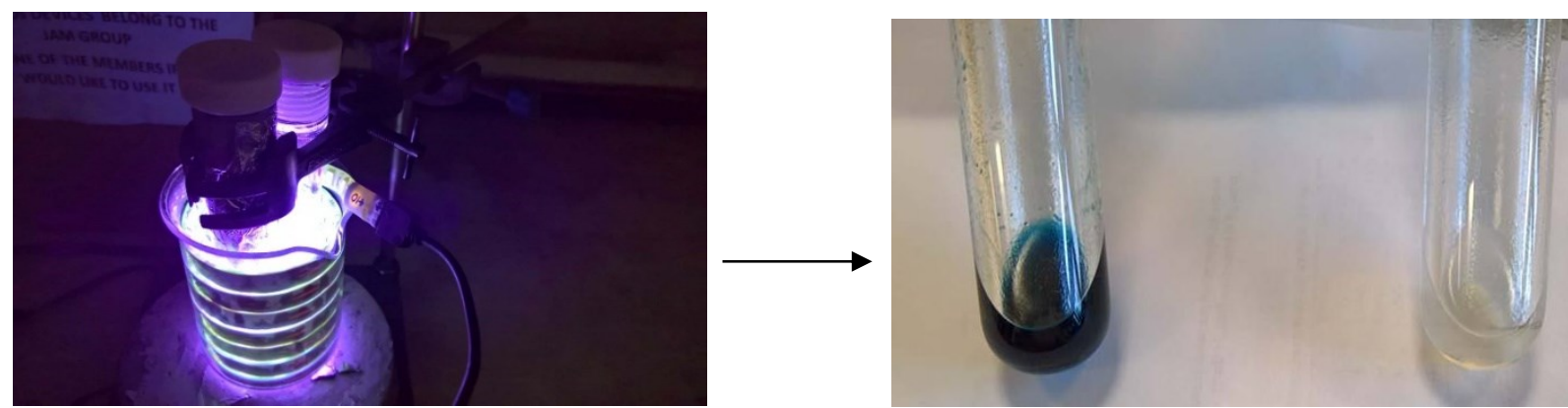

Figure S2. Above is a typical example of reaction $\mathbf{1 7}+\mathrm{KO} t \mathrm{Bu} 2$ eq in benzene $2.5 \mathrm{~mL}$ performed under Vis LEDs light (400 $\mathrm{nm}, 14.4 \mathrm{~W})$ at RT. Only the tube with a direct exposition to the light gives the typical blue coloration of the ketyl radical, afterwards confirmed by UV measurement. 


\section{LED Output Spectra}

These spectra were produced using a BWTEK Inc, Exemplar LS (Low Straylight Smart CCD Spectrometer, http://bwtek.com/products/exemplar-ls/ )

(i) Reference spectrum taken of a Ushio Opto Semiconductors Inc. 450 nm: SMBB450H-1100-02

(Full details in SI of https://doi.org/10.1002/cptc.201800082 page S10)

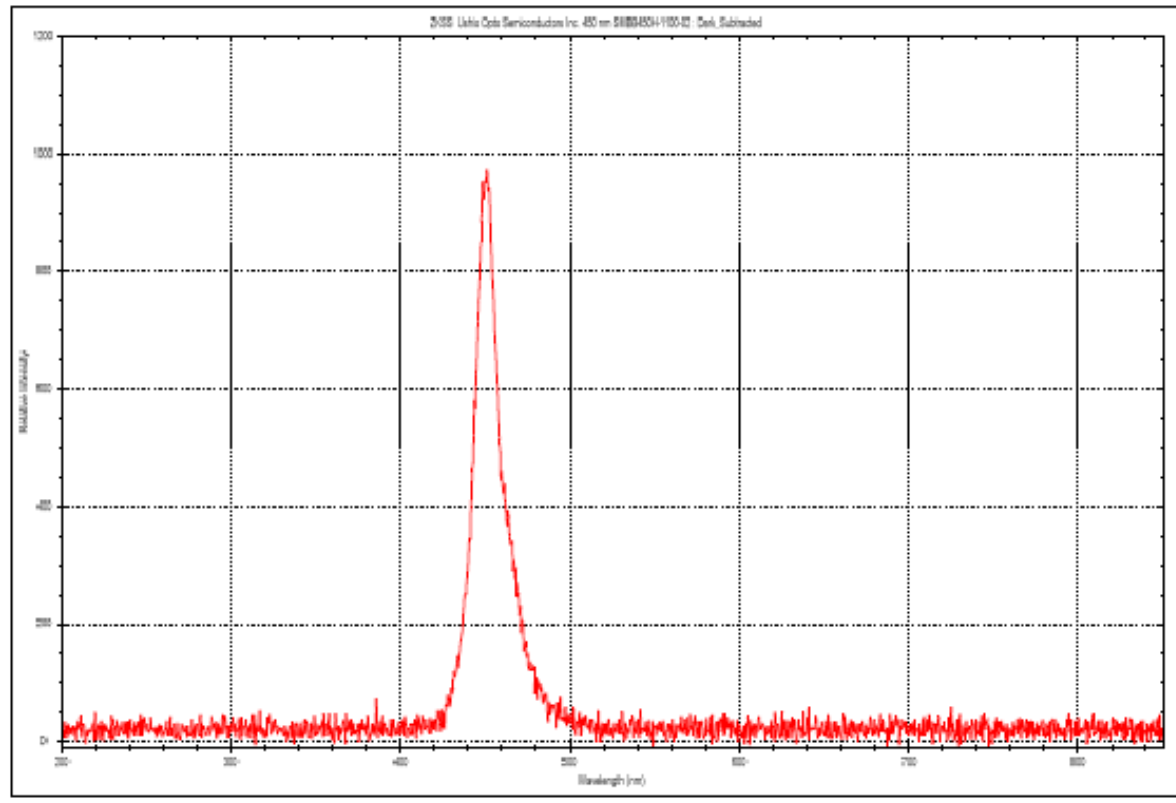

(ii) Spectrumof SMD5050;60LEDs/M; Color: UV('410nm’)

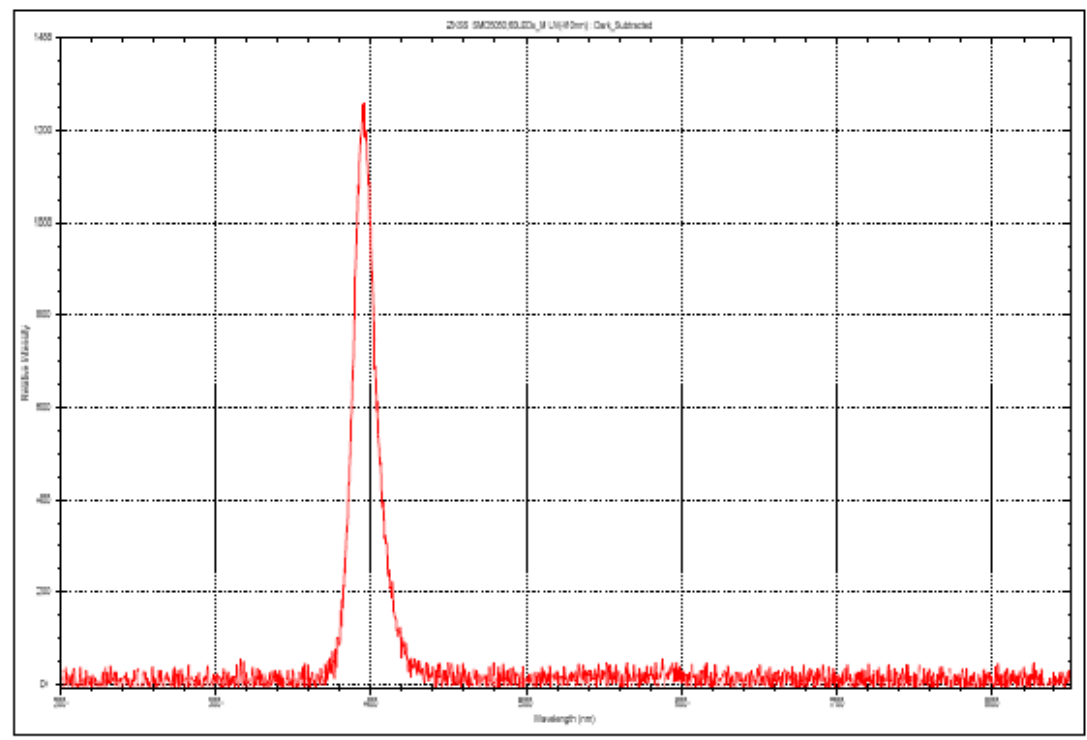




\section{Luminous flux measurements}

\section{Luminous flux}

Luminous flux measurements were taken with a Traceable ${ }^{\circledR}$ Dual-Display Light Meter (https://traceable.com/3252-traceable-dual-displaylight-meter.html purchased from Fisher Scientific).

The Lux sensor was placed inside the coil of SMD5050;60LEDs Figure X, and the setup covered with tin foil to remove any external light.
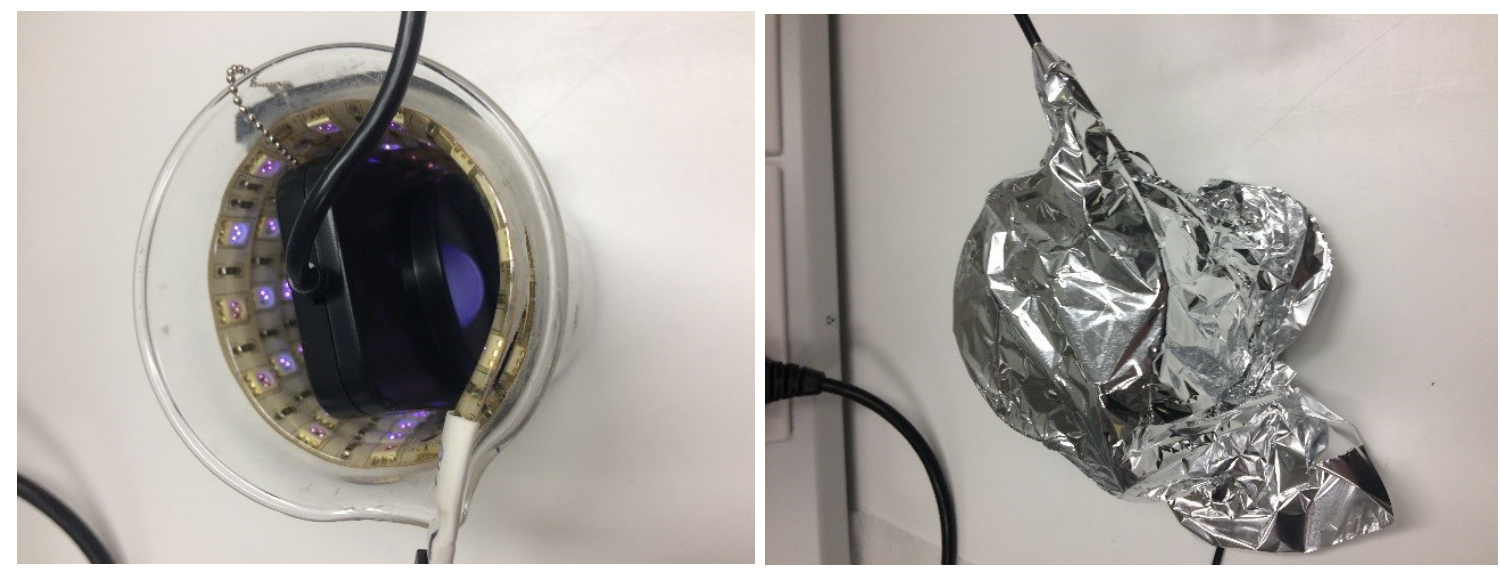

Figure X Lux measurement set up

Traceable ${ }^{\circledR}$ Dual-Display Light Meter was set to $\mathrm{F}=$ fluorescent mode, the LEDs where turned on a LUX reading taken, 39 LUX.

\section{Detection of methylated and ethylated benzophenone}

\section{$\operatorname{Phenyl}(p$-tolyl)methanone, 35}

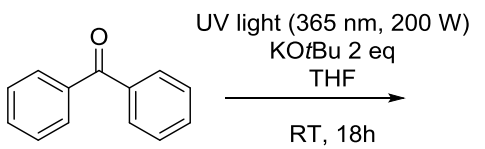

17
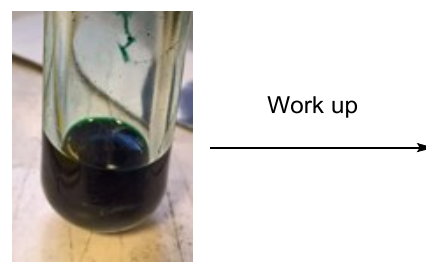

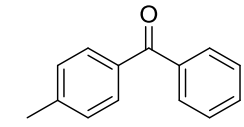

35 phenyl $(p-$ tolyl)methanone Exact Mass: 196.0888

Detected via GC-MS

Benzophenone $17(91 \mathrm{mg}, 0.5 \mathrm{mmol}), \mathrm{KO} t \mathrm{Bu}(112 \mathrm{mg}, 1 \mathrm{mmol})$ were loaded in a $15 \mathrm{~mL}$ pressure tube with THF (2.5 mL). The sealed tube was then moved out from the glovebox and placed under UV light for $18 \mathrm{~h}$. The dark green/blue colour gradually developed from the start of the reaction. After $18 \mathrm{~h}$ the tube was opened and water was added. The dark coloration disappear after few seconds of air exposure or water contact. The mixture was then extracted with ether, dried over sodium sulfate and concentrated in vacuo. The residue was analysed via TOF MS EI (see spectrum below). The fragmentation pattern is consistent with the literature data for the ketone 35. (lit: GCMS (EI) (\%): 196 (M+ , 43), 181(9), $165(4), 152(4), 119(100), 105(32), 91(46), 77(43)) .^{7}$ 


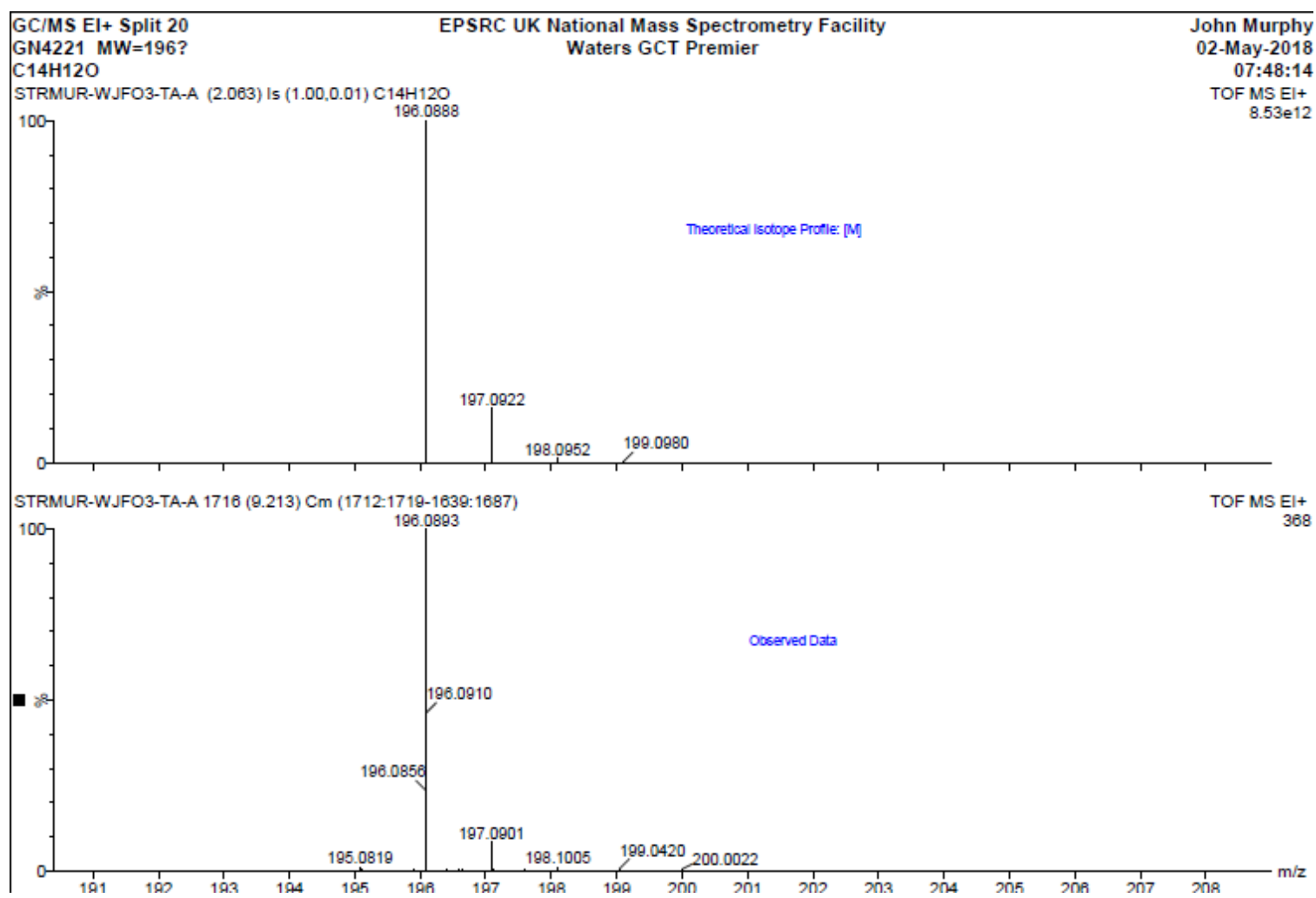

Figure S3 Calculated and observed high resolution mass spectra of phenyl( $p$-tolyl)methanone 35

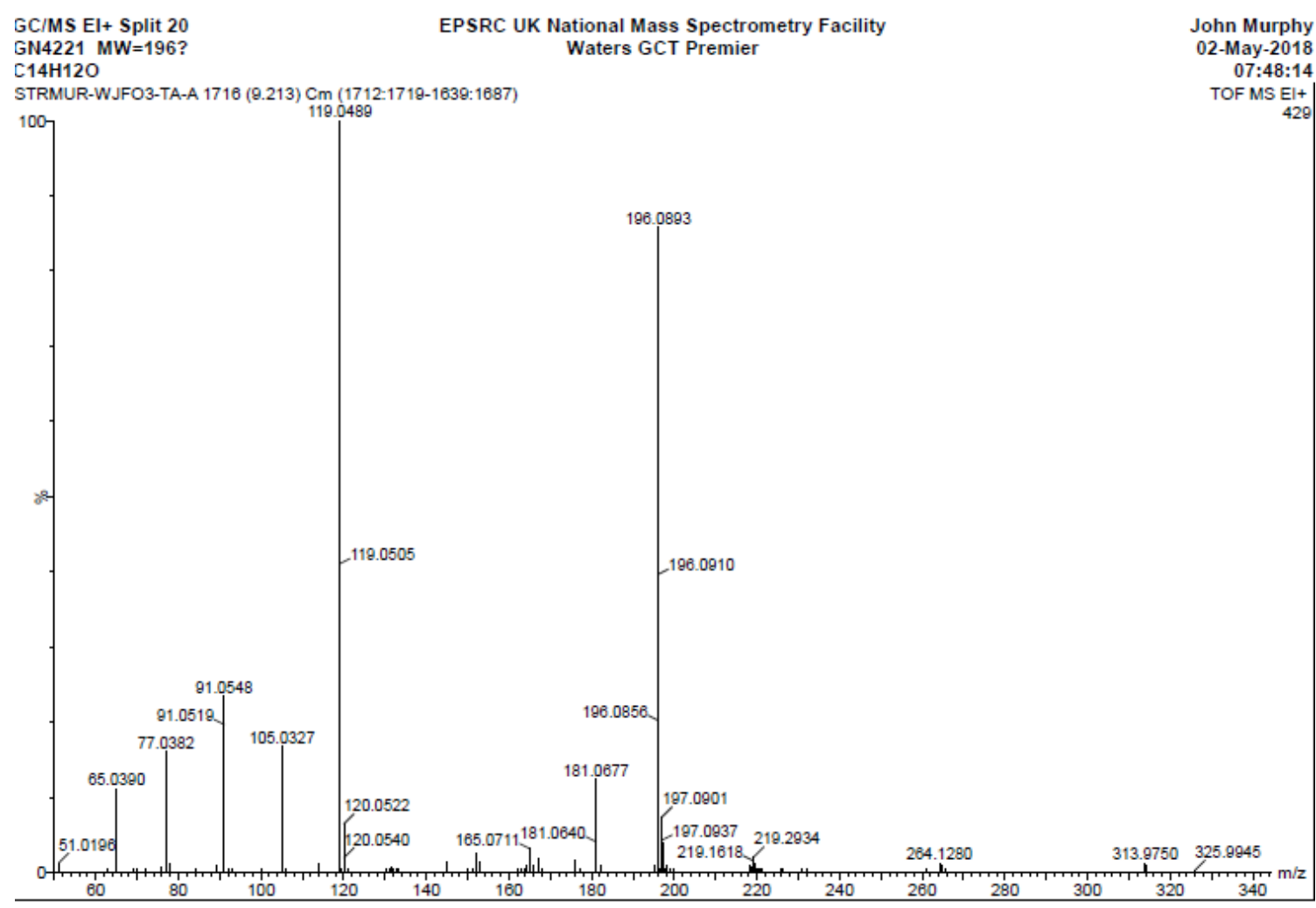

Figure S4. EI spectrum of phenyl( $p$-tolyl)methanone 35 


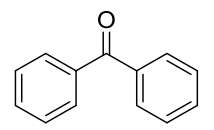

17

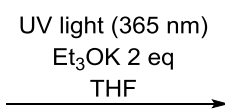

RT, $18 \mathrm{~h}$

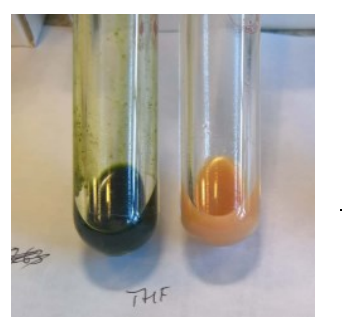

Uncovered (left) and covered (right) with foil

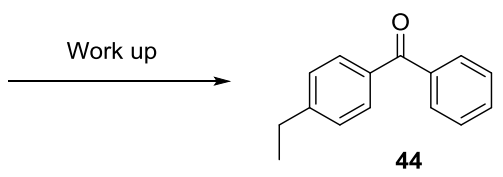

(4-ethylphenyl)(phenyl)methanone

Chemical Formula: $\mathrm{C}_{15} \mathrm{H}_{14} \mathrm{O}$

Exact Mass: 210.1045

Molecular Weight: 210.2760

Benzophenone 17 (91 mg, $0.5 \mathrm{mmol}), \mathrm{KOEt}_{3}(154 \mathrm{mg}, 1 \mathrm{mmol})$ were loaded in a $15 \mathrm{~mL}$ pressure tube with THF (2.5 mL). The sealed tube was then moved out from the glovebox and placed under UV light for $18 \mathrm{~h}$. The dark green/blue colour was gradually developed since the start of the reaction. The blank reaction (absence of any source of lights) does not give any blue/green colour throughout the entire course of the reaction. After $18 \mathrm{~h}$ the tube was opened and water was added. The dark coloration disappeared after few seconds of air exposure or water contact. The mixture was then extracted with ether, dried over sodium sulfate and concentrated in vacuo. The residue was analyzed via TOF MS EI+ (see spectra below).

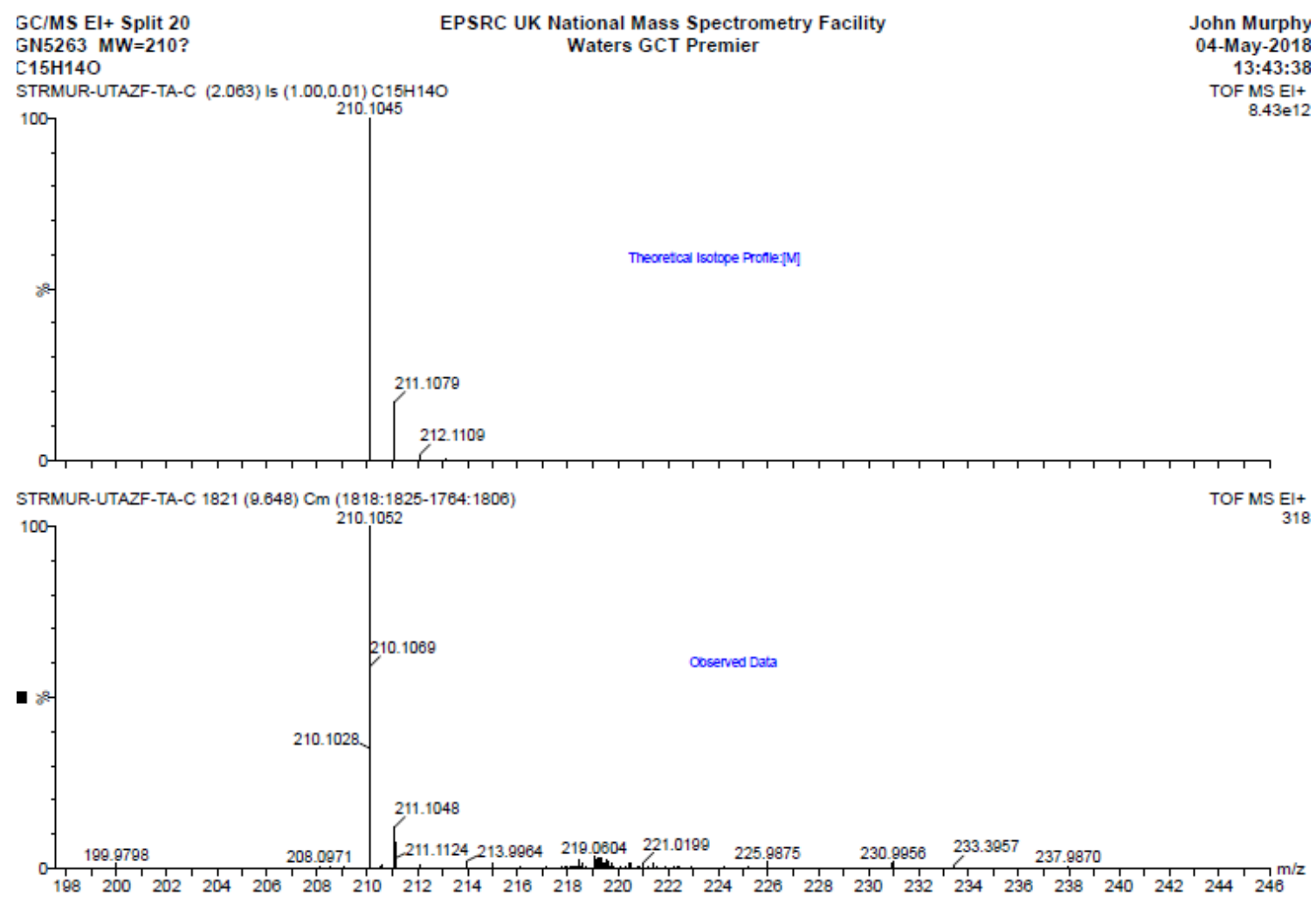

Figure S5. Calculated and observed high resolution mass spectra of of 4-ethylphenyl)(phenyl)methanone 44 


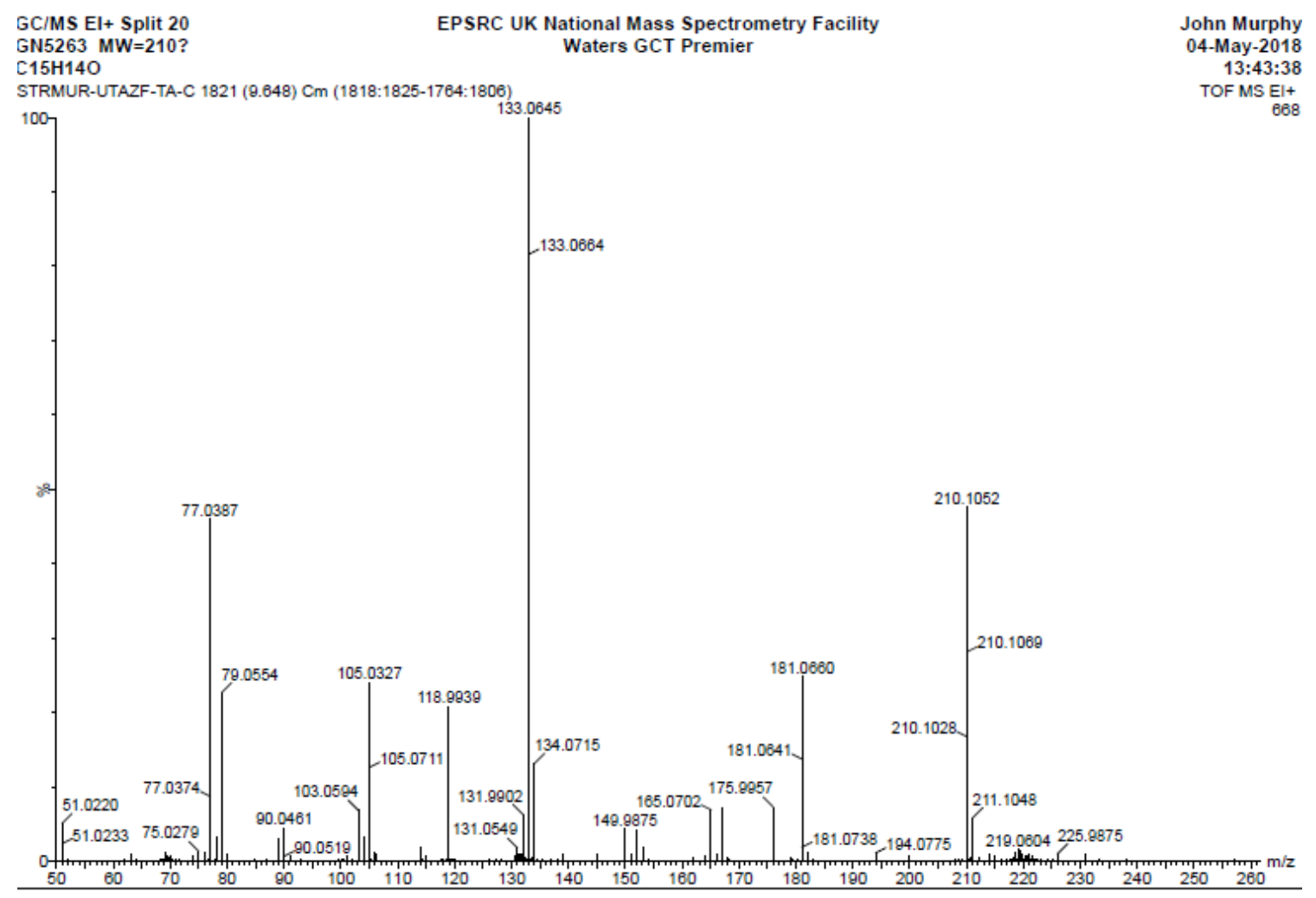

Figure S6. EI spectrum of 4-ethylphenyl)(phenyl)methanone 44 


\section{UV measurements}

Every solution was prepared in the glovebox using distilled THF $(3 \mathrm{~mL})$ and a quartz standard cuvette.

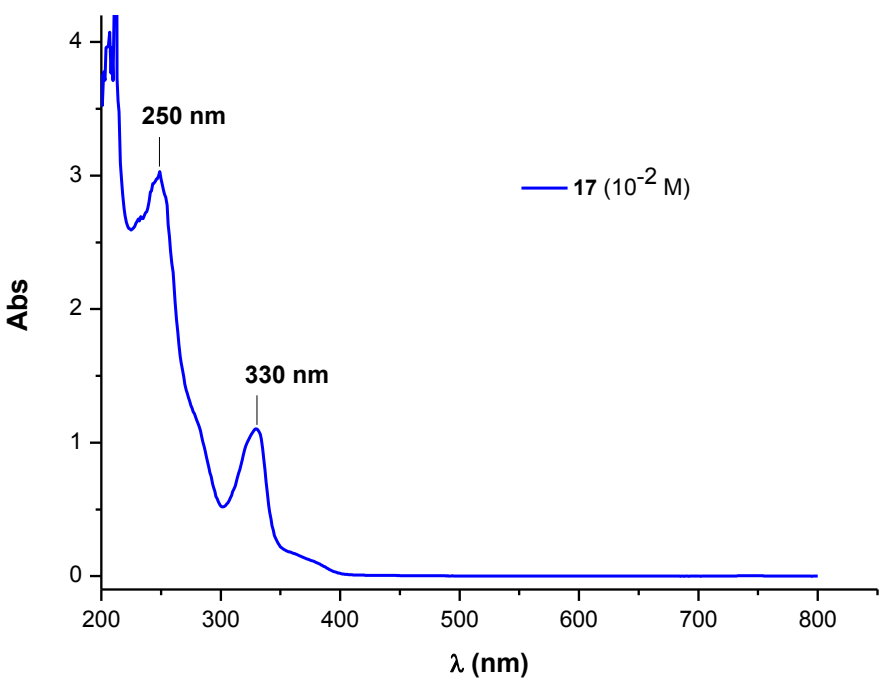

Figure S7. UV spectrum of benzophenone $17\left(10^{-2} \mathbf{M}\right)$ in THF

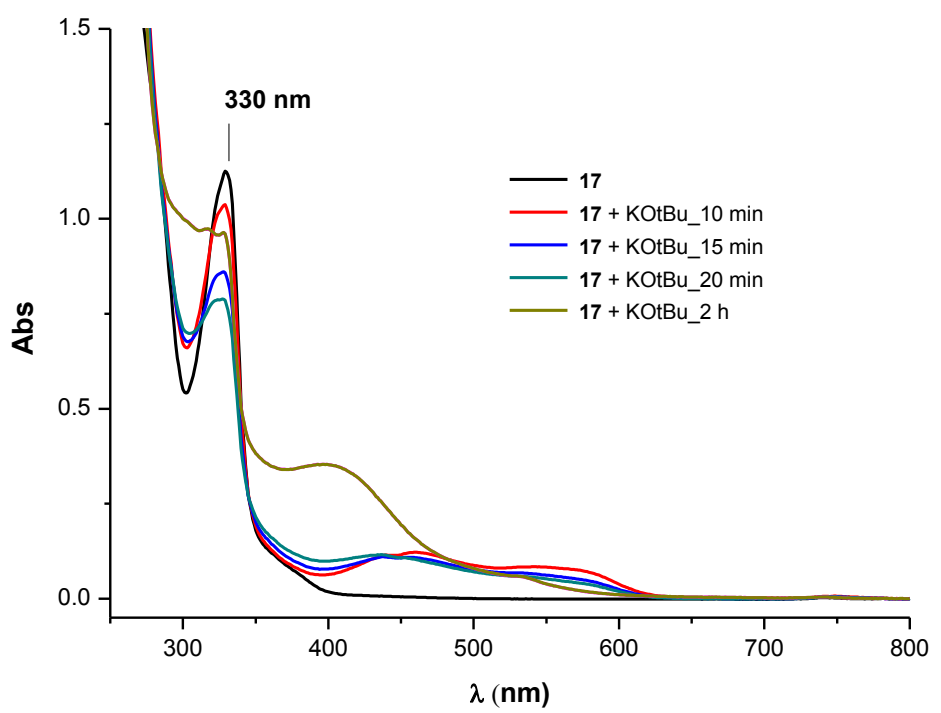

Figure S8. UV spectrum of benzophenone $17\left(10^{-2} \mathbf{M}\right)$ in THF; In the presence of $\mathrm{KO} t \mathrm{Bu}$, a bathochromic expansion of the absorption occurs with the time. 


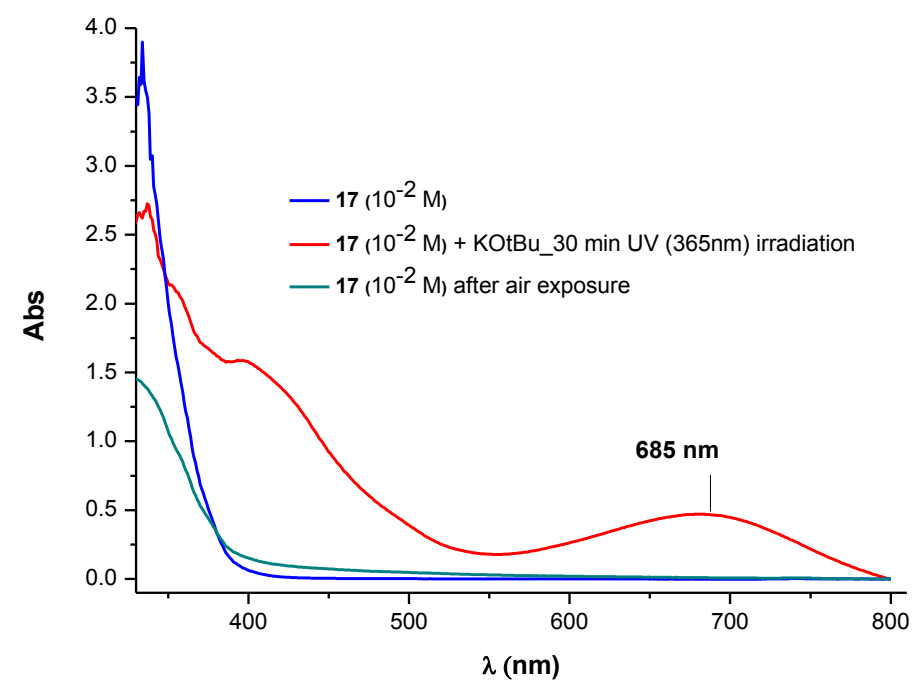

Figure S9. Formation of the ketyl radical 18 after irradiating the complex 17+KOtBu with UV light (365 nm, 100W x 2).

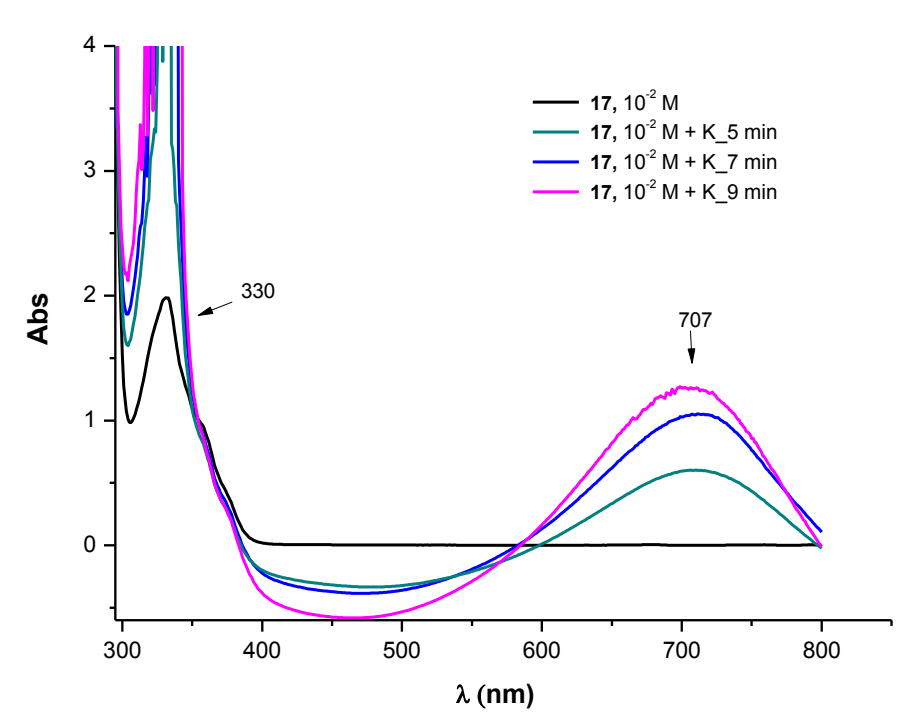

Figure S10. UV spectrum of $\mathbf{1 7} 10^{-2} \mathbf{M}$ in presence of an excess of potassium metal. In the first 10 minutes formation of the ketyl radical peak around $700 \mathrm{~nm}$ was observed. The concentration of BZP used needs to be around $10^{-2}-10^{-3} \mathbf{M}$ to make evident the development of the ketyl radical anion 18 peak. This spectrum is consistent with the literature. ${ }^{8}$ 


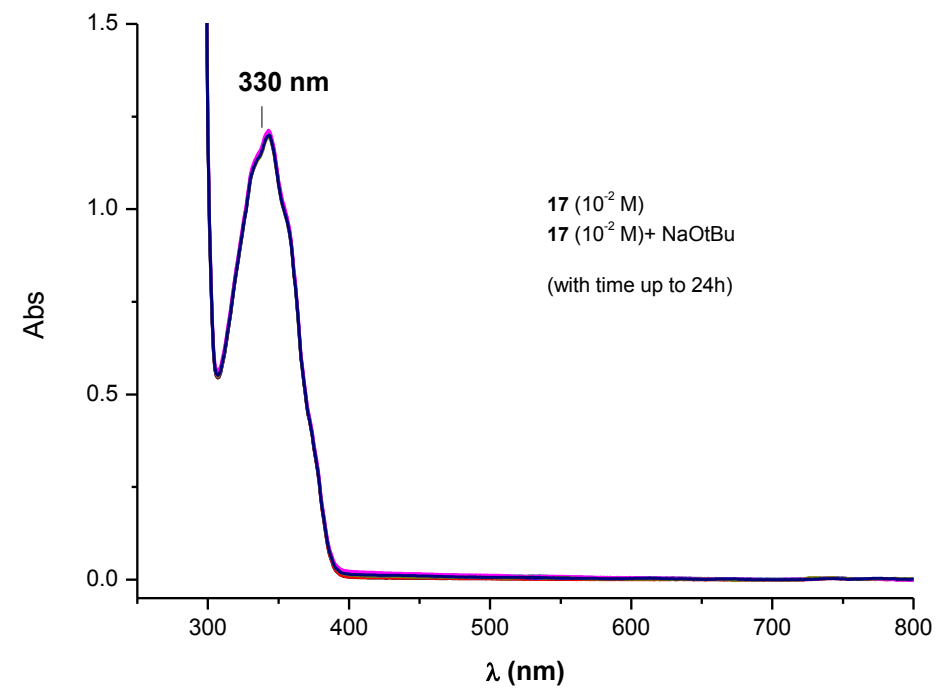

Figure S 11. UV measurements of $\mathbf{1 7}\left(10^{-2} \mathbf{M}\right)$ before and after adding $\mathrm{NaO} t \mathrm{Bu}$. The cuvette was agitated and measurements were taken every $10 \mathrm{~min}$ for $1 \mathrm{~h}$. The cuvette was then left overnight and no shift was observed the following day. No colour change in the cuvette was observed.

\section{NMR tests throughout the reaction}

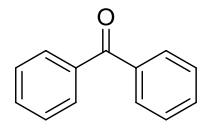

17
KOtBu 2 eq

Benzene $d^{6}$

RT, hv, 5 min

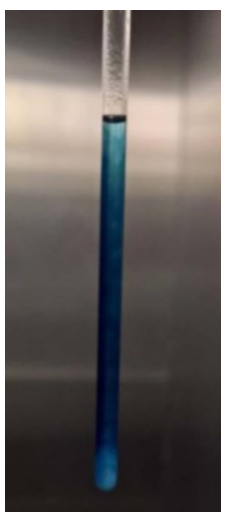

Figure S 12. The signals from structure 17 disappear just after 5 minutes UV exposure, indicating that radical species and macromolecular structures are formed in the reaction. ${ }^{8}$ 
${ }^{1} \mathrm{H}$ NMR spectrum of benzophenone $\mathbf{1 7}$

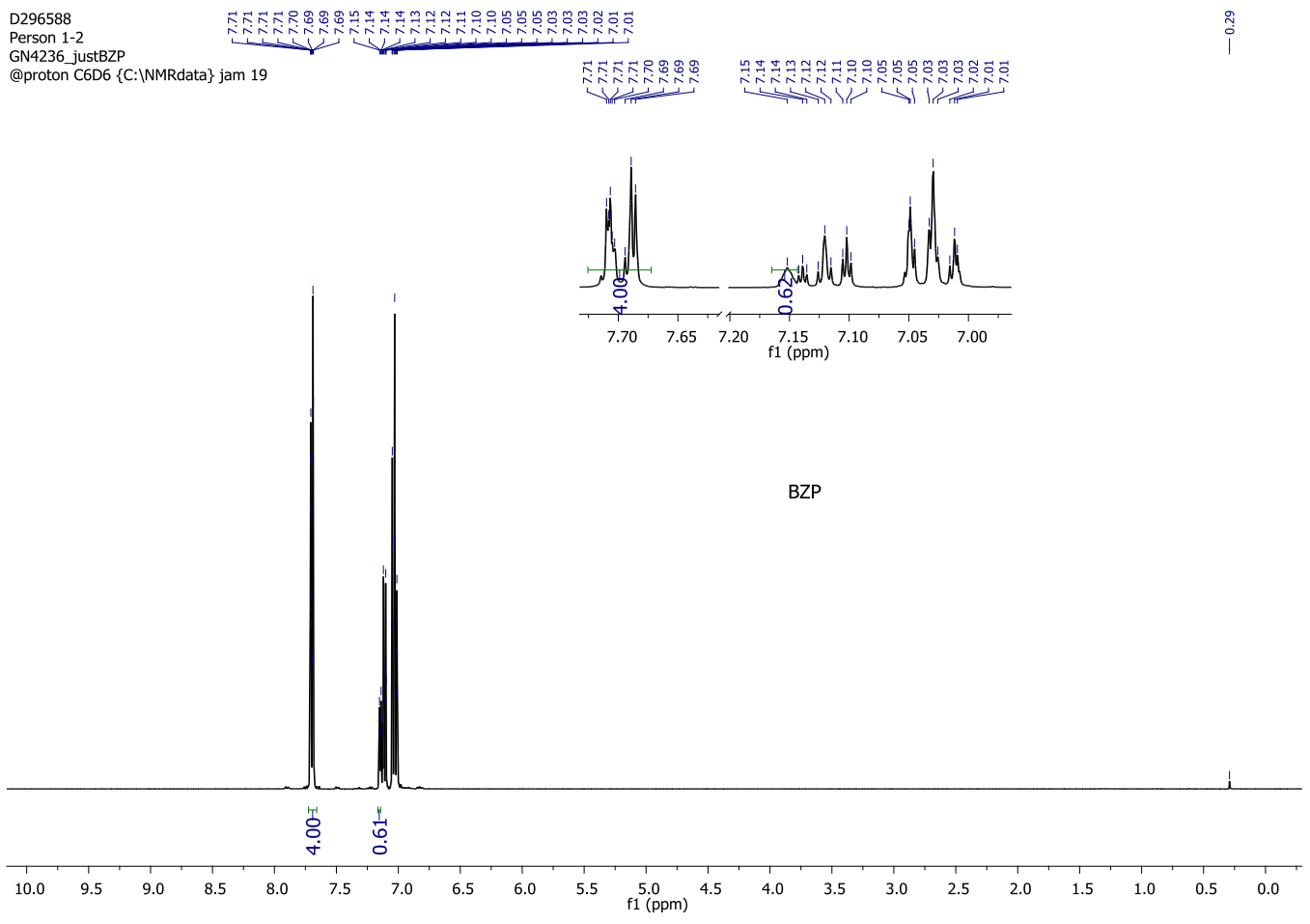

${ }^{1} \mathrm{H}$ NMR spectrum of benzophenone $\mathbf{1 7}+\mathrm{KO} t \mathrm{Bu}$

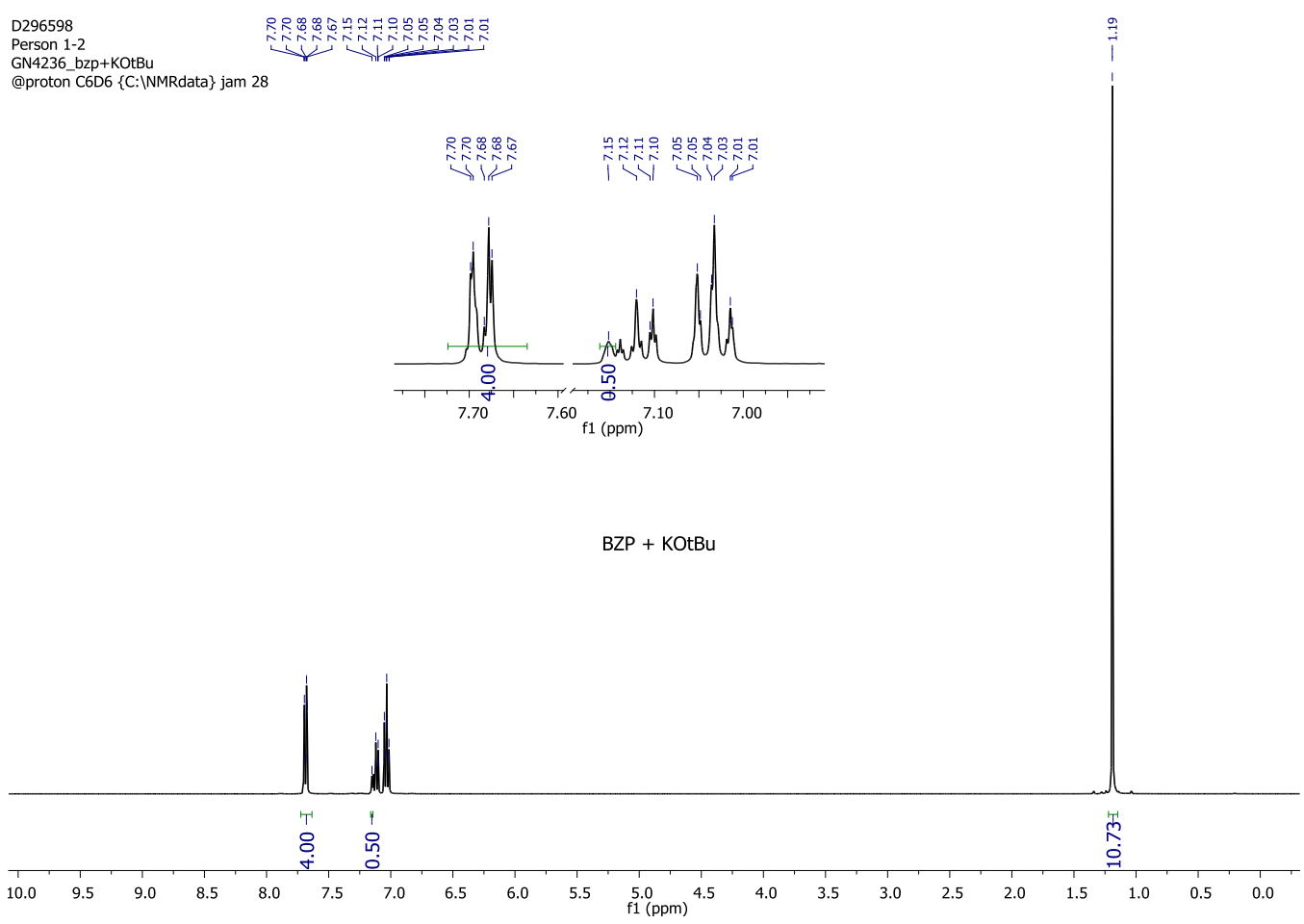


${ }^{1} \mathrm{H}$ NMR spectrum of benzophenone $\mathbf{1 7}+\mathrm{KO} t \mathrm{Bu}$ after 5 min irradiation with $\mathrm{UV}(365 \mathrm{~nm})$

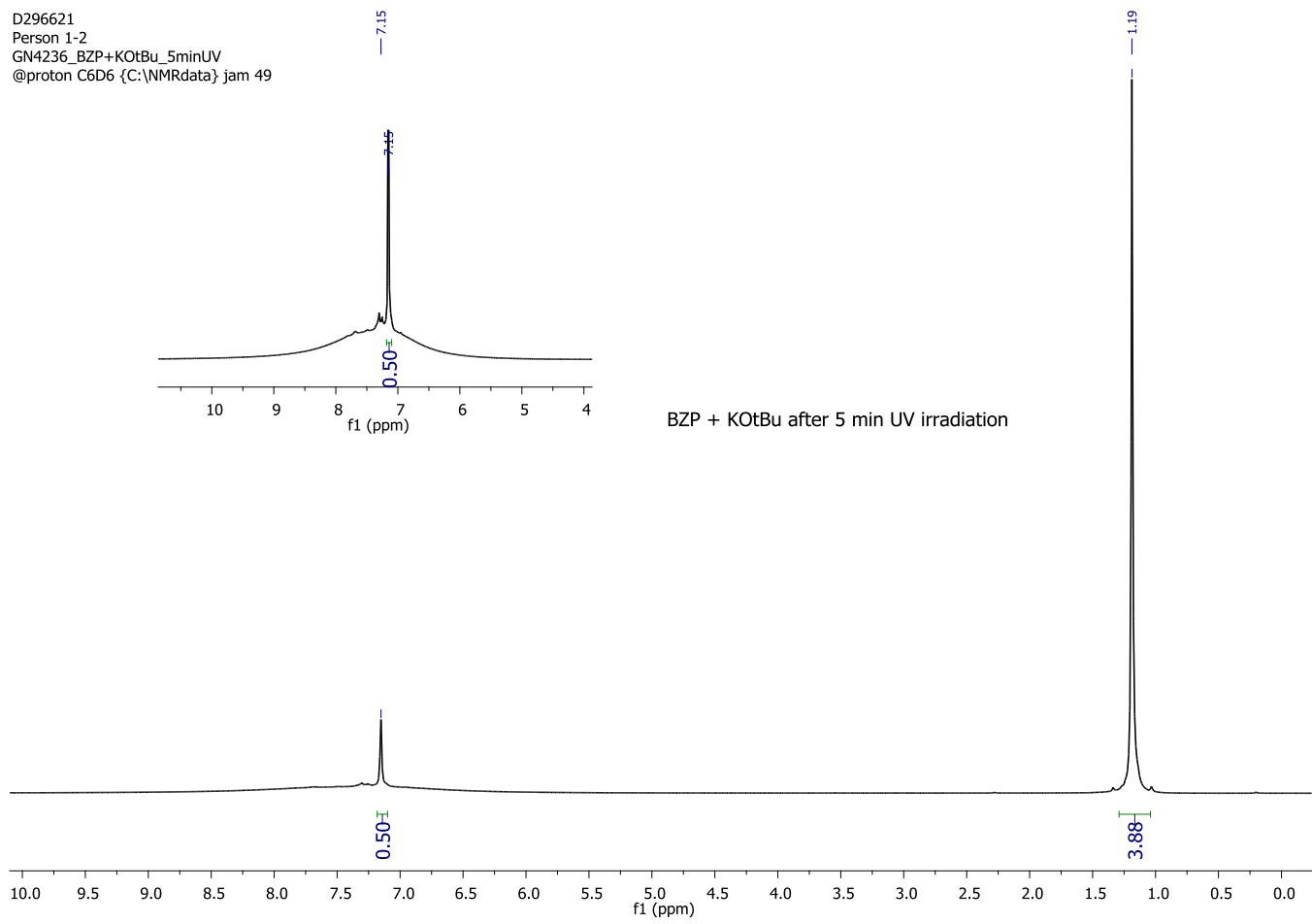

${ }^{1} \mathrm{H}$ NMR spectrum of benzophenone $\mathbf{1 7}+\mathrm{KO} t \mathrm{Bu}$ after 5 min irradiation with $\mathrm{UV}(365 \mathrm{~nm})$, then standing for $24 \mathrm{~h}$

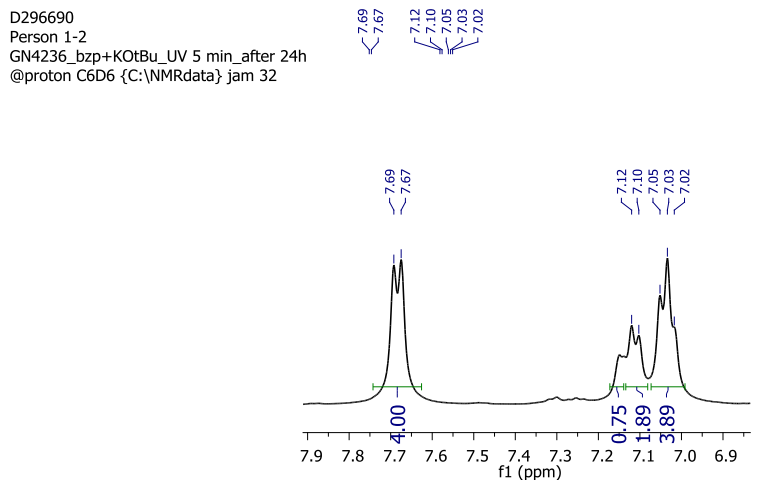

BZP+ KOtBu after 5 min Uv irradiation_after 24h

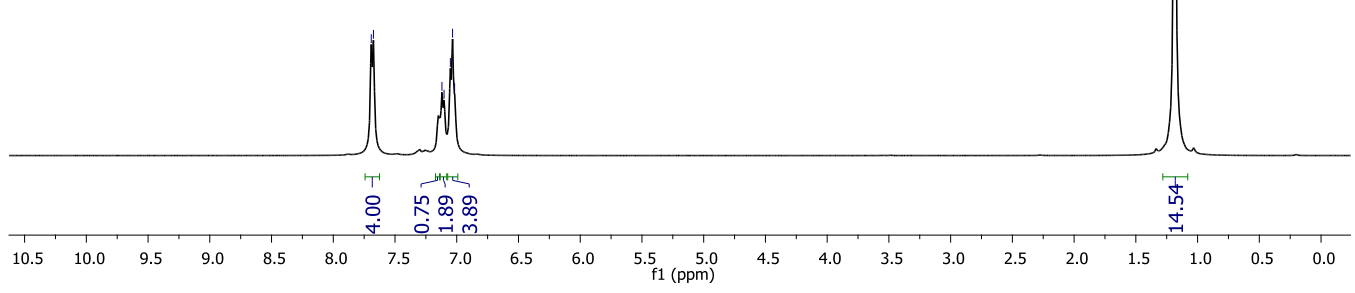




\section{General conditions and yield calculations for cross coupling reactions}

Reactions with iodo- $m$-xylene using the aromatic ketones as additives.

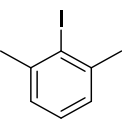

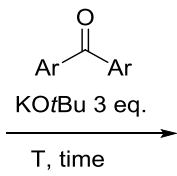

T, time

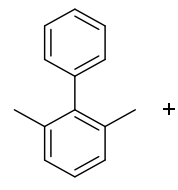

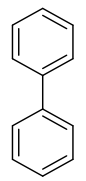

7

A mixture of iodo- $m$-xylene $6(0.5 \mathrm{mmol}), \mathrm{KO} t \mathrm{Bu}(3.0$ eq.) and the desired aromatic ketone $(0.2 \mathrm{eq})$ in benzene $(5 \mathrm{~mL}) \mathrm{was}$ sealed in a 15 $\mathrm{mL}$ pressure tube in a glovebox. The tube was removed from the glovebox and heated at $130{ }^{\circ} \mathrm{C}$ for $18 \mathrm{~h}$ behind a blast shield. After cooling to room temperature, the reaction was quenched by water $(15 \mathrm{~mL})$ and acidified with $1 \mathrm{~N}$ hydrochloric acid until neutral $\mathrm{pH}$. The mixture was extracted with diethyl ether $(3 \times 15 \mathrm{~mL})$. The organic layer was dried over sodium sulfate, filtered and concentrated to give rise to the residue. Since the coupled products 9 and 7 are inseparable, the yields were calculated from NMR spectra via internal standard. 1,3,5-trimethoxybenzene $8.4 \mathrm{mg},(0.050 \mathrm{mmol}, 10 \mathrm{~mol} \%)$ which was added as a solid to the reaction mixture, $\sim 1 \mathrm{~mL} \mathrm{CDCl} 3 \mathrm{mas}$ added to form a homogeneous solution and the solution stirred. A portion of the solution was taken and diluted for NMR analysis.

Cross coupling reaction using 17 as additive.

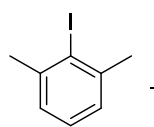

6

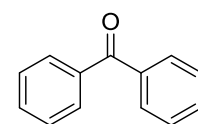

17

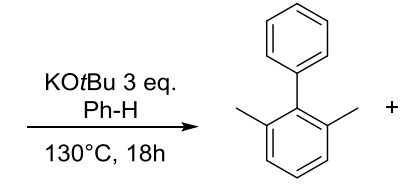

9

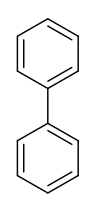

7

A mixture of 1-iodo-2,6-dimethylbenzene 6 (116 mg, $0.5 \mathrm{mmol}), \mathrm{KO} t \mathrm{Bu}$ (168 mg, $1.5 \mathrm{mmol}$ ) and 17 (18.2 mg; $0.01 \mathrm{mmol})$ in benzene ( 5 $\mathrm{mL}$ ) was sealed in a $15 \mathrm{~mL}$ pressure tube in a glovebox. The tube was removed from the glovebox and heated at $130{ }^{\circ} \mathrm{C}$ for $18 \mathrm{~h} \mathrm{behind} \mathrm{a}$ blast shield. After cooling to room temperature, the reaction was quenched by water $(15 \mathrm{~mL})$ and acidified with $1 \mathrm{~N} \mathrm{HCl} \mathrm{until} \mathrm{neutral} \mathrm{pH}$. The mixture was extracted with diethyl ether $(15 \mathrm{~mL})$. The organic layer was dried over sodium sulfate, filtered and concentrated to give the residue as a dark yellow oil. The yield was calculated using 1,3,5-trimethoxybenzene (10\%) as internal standard. The quantity of each product was determined as following (also see annotated example spectrum below):

For the recovered starting material 6 the integration of methoxy signal of the internal standard in the ${ }^{1} \mathrm{H}-\mathrm{NMR}$ spectrum was set to 9 units. The integration of the methyl signal of $6(2.50 \mathrm{ppm})$ was then measured and the following calculation gave the amount of 6 present:

$(3.11 / 6) \times 10=5.2 \%$

For the hetero-coupled product 9 , the integration of the methoxy signal of the internal standard in the ${ }^{1} \mathrm{H}-\mathrm{NMR}$ spectrum was set to 9 units. The integration of the methyl signal of $\mathbf{9}(2.04 \mathrm{ppm})$ was then measured and the following calculation gave the amount of 9 present:

$(0.65 / 6) \times 10=1.1 \%$

For the biphenyl product 7 the integration of the aromatic signal of the internal standard was set to 3 units. The integration of the aromatic signals of 7 at 7.64-7.59 ppm $(4 \mathrm{H})$ was then measured and the following calculation gave the amount of 7 present:

$($ int $/ 4) \times 10=$ yield $\%$ but see text below the next spectrum $* *$ 


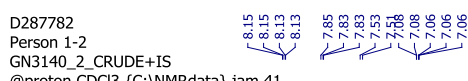<smiles>Cc1cccc(C)c1-c1ccccc1</smiles>

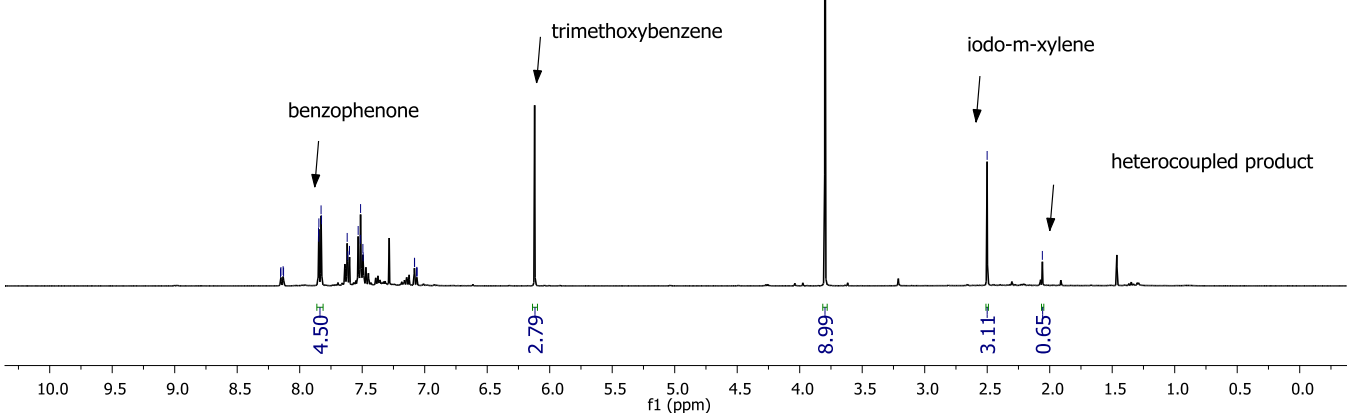

**In this particular case the diagnostic peak of biphenyl overlaps with one of the benzophenone peak. In the BHAS mediated mechanism the ratio between biphenyl and heterocoupled product is always 3:1. In fact, after purification by chromatography the inseparable mixture was indeed in 3:1 ratio. Integrating the methyl group $(6 \mathrm{H}, 2.06 \mathrm{ppm})$ as 6 the ratio of biphenyl $(4 \mathrm{H}, 7.62 \mathrm{ppm})$ is:

$(12.15 / 4)=3.0$

Since the ratio was found to be $3: 1$, the tiled of biphenyl present in the mixture was $3.3 \%$.

Number of runs: (a) Biphenyl $3.3 \%$; 1,3-dimethylbiphenyl $1.1 \%$. (b) Biphenyl 3.6 \% ; 1,3-dimethylbiphenyl 1.2\%. (c) Biphenyl 3.6 \% ; 1,3-dimethylbiphenyl $1.2 \%$

Average of 3 runs: Biphenyl $3.5 \%$; 1,3-dimethylbiphenyl 1.2\%.

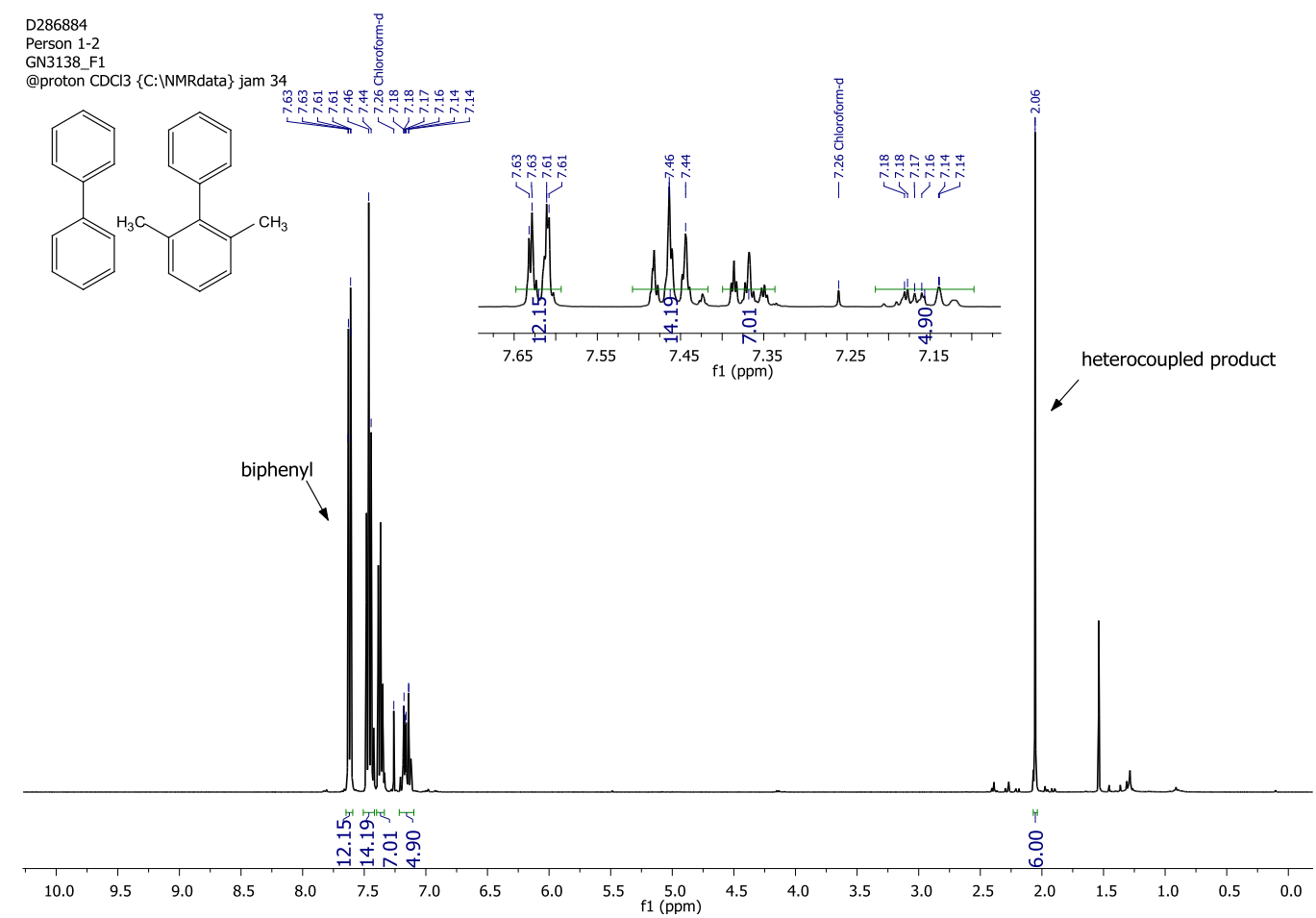


Cross coupling reaction using 27 as additive.

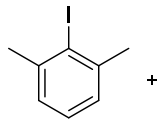

6

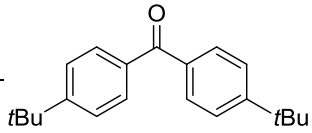

27

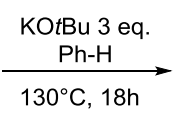

$130^{\circ} \mathrm{C}, 18 \mathrm{~h}$

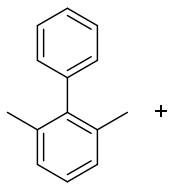

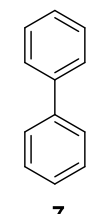

A mixture of 1-iodo-2,6-dimethylbenzene 6 (116 mg, $0.5 \mathrm{mmol}), \mathrm{KO} t \mathrm{Bu}(168 \mathrm{mg}, 1.5 \mathrm{mmol})$ and 27 (29.4 mg; $0.1 \mathrm{mmol})$ in benzene ( 5 $\mathrm{mL}$ ) was sealed in a $15 \mathrm{~mL}$ pressure tube in a glovebox. The tube was removed from the glovebox and heated at $130{ }^{\circ} \mathrm{C}$ for $18 \mathrm{~h}$ behind a blast shield. After cooling to room temperature, the reaction was quenched by water $(15 \mathrm{~mL})$ and acidified with $1 \mathrm{~N} \mathrm{HCl} \mathrm{until} \mathrm{neutral} \mathrm{pH}$. The mixture was extracted with diethyl ether $(15 \mathrm{~mL})$. The organic layer was dried over sodium sulfate, filtered and concentrated to give the residue as a dark yellow oil which yielded $1.0 \%$ of 9 and $3.2 \%$ of 7 . The yield was calculated using $1,3,5$-trimethoxybenzene (10\%) as internal standard.

Cross coupling reaction using $\mathbf{2 8}$ as additive.

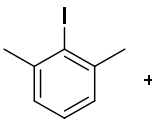

6<smiles>Cc1cc(C)c(C(=O)c2c(C)cc(C)cc2C)c(C)c1</smiles>

27
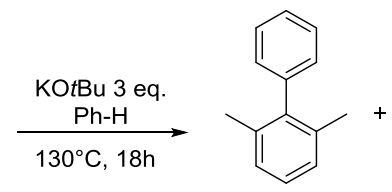

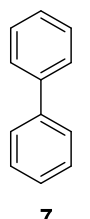

7

A mixture of 1-iodo-2,6-dimethylbenzene 6 (116 mg, $0.5 \mathrm{mmol}), \mathrm{KO} t \mathrm{Bu}(168 \mathrm{mg}, 1.5 \mathrm{mmol})$ and 28 (26.6 mg; $0.1 \mathrm{mmol})$ in benzene ( 5 $\mathrm{mL}$ ) was sealed in a $15 \mathrm{~mL}$ pressure tube in a glovebox. The tube was removed from the glovebox and heated at $130{ }^{\circ} \mathrm{C}$ for $18 \mathrm{~h} \mathrm{behind} \mathrm{a}$ blast shield. After cooling to room temperature, the reaction was quenched by water $(15 \mathrm{~mL})$ and acidified with $1 \mathrm{~N} \mathrm{HCl} \mathrm{until} \mathrm{neutral} \mathrm{pH}$. The mixture was extracted with diethyl ether $(15 \mathrm{~mL})$. The organic layer was dried over sodium sulfate, filtered and concentrated to give the residue as a dark yellow oil which yielded $0.7 \%$ of 9 and $1.8 \%$ of 7 . The yield was calculated using $1,3,5$-trimethoxybenzene (10\%) as internal standard.

Cross coupling reaction using $\mathbf{2 9}$ as additive.

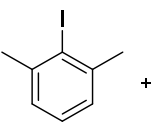

6<smiles>O=C(c1ccc(-c2ccccc2)cc1-c1ccccc1)c1c(-c2ccccc2)cccc1-c1ccccc1</smiles>

29

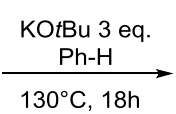

$130^{\circ} \mathrm{C}, 18 \mathrm{~h}$

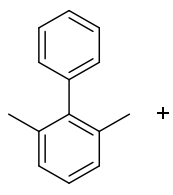

9

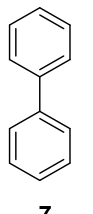

7

A mixture of 1-iodo-2,6-dimethylbenzene 6 (116 mg, $0.5 \mathrm{mmol}), \mathrm{KO} t \mathrm{Bu}(168 \mathrm{mg}, 1.5 \mathrm{mmol})$ and 28 (56.2 $\mathrm{mg}$; $0.1 \mathrm{mmol}) \mathrm{in} \mathrm{benzene} \mathrm{(} 5$ $\mathrm{mL}$ ) was sealed in a $15 \mathrm{~mL}$ pressure tube in a glovebox. The tube was removed from the glovebox and heated at $130{ }^{\circ} \mathrm{C}$ for $18 \mathrm{~h} \mathrm{behind} \mathrm{a}$ blast shield. After cooling to room temperature, the reaction was quenched by water $(15 \mathrm{~mL})$ and acidified with $1 \mathrm{~N} \mathrm{HCl}$ until neutral $\mathrm{pH}$. The mixture was extracted with diethyl ether $(15 \mathrm{~mL})$. The organic layer was dried over sodium sulfate, filtered and concentrated to give the residue as a dark yellow oil which yielded $0.8 \%$ of 9 and $2.4 \%$ of 7 . The yield was calculated using $1,3,5$-trimethoxybenzene (10\%) as internal standard. 
Cross coupling reaction using $\mathbf{3 0}$ as additive.

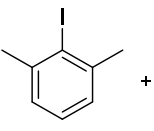

6

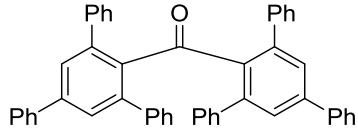

30

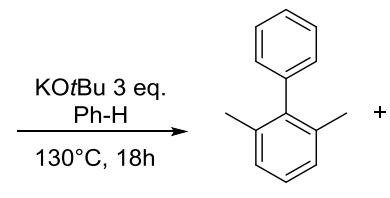

9

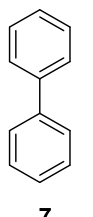

7

A mixture of 1-iodo-2,6-dimethylbenzene 6 (116 mg, $0.5 \mathrm{mmol}), \mathrm{KO} t \mathrm{Bu}(168 \mathrm{mg}, 1.5 \mathrm{mmol})$ and 28 (63.8 mg; $0.1 \mathrm{mmol})$ in benzene ( 5 $\mathrm{mL}$ ) was sealed in a $15 \mathrm{~mL}$ pressure tube in a glovebox. The tube was removed from the glovebox and heated at $130{ }^{\circ} \mathrm{C}$ for $18 \mathrm{~h}$ behind a blast shield. After cooling to room temperature, the reaction was quenched by water $(15 \mathrm{~mL})$ and acidified with $1 \mathrm{~N} \mathrm{HCl} \mathrm{until} \mathrm{neutral} \mathrm{pH}$. The mixture was extracted with diethyl ether $(15 \mathrm{~mL})$. The organic layer was dried over sodium sulfate, filtered and concentrated to give the residue as a dark yellow oil which yielded $0.4 \%$ of 9 and $1.2 \%$ of 7 . The yield was calculated using $1,3,5$-trimethoxybenzene (10\%) as internal standard.

Reactions with iodo-para-toluene using 17 as additive

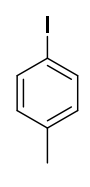

36

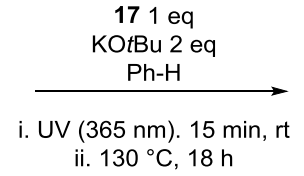

ii. $130^{\circ} \mathrm{C}, 18 \mathrm{~h}$

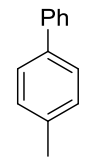

37

A mixture of iodo-p-toluene $36(0.5 \mathrm{mmol}), \mathrm{KO} t \mathrm{Bu}(112 \mathrm{mg}, 1 \mathrm{mmol}), 17$ (91 mg, $0.5 \mathrm{mmol}$, if added) in benzene (2.5 mL) was sealed in a $15 \mathrm{~mL}$ pressure tube in glovebox. The tube was removed from the glovebox and placed RT for 15 min under UV (365 nm) irradiation and then transferred into an oil bath at $130{ }^{\circ} \mathrm{C}$ for $18 \mathrm{~h}$. After cooling to room temperature, the reaction was quenched by water $(15 \mathrm{~mL})$ and acidified with $1 \mathrm{~N} \mathrm{HCl}$ until neutral $\mathrm{pH}$. The mixture was extracted with diethyl ether $(3 \mathrm{x} 15 \mathrm{~mL})$. The organic layer was dried over sodium sulfate, filtered and concentrated to give rise to the residue. 1,3,5-Trimethoxybenzene $8.4 \mathrm{mg},(0.050 \mathrm{mmol}, 10 \mathrm{~mol} \%)$ was added as a solid to the reaction mixture, $\sim 1 \mathrm{~mL} \mathrm{CDCl}_{3}$ was added and the solution stirred. A portion of the solution was taken and diluted for NMR analysis. The quantity of product was determined as following. For the recovered starting material the integration of methoxy signal $(3.81 \mathrm{ppm})$ of the internal standard in the ${ }^{1} \mathrm{H}-\mathrm{NMR}$ spectrum was set to 9 units. The integration of the methyl signal of $\mathbf{3 6}(3 \mathrm{H}, 2.33 \mathrm{ppm})$ was then measured and the following calculation gave the amount of $\mathbf{3 6}$ present:

$(6.24 / 3) \times 10=21 \%$

For the product 37 the integration of methoxy signal of the internal standard in the ${ }^{1} \mathrm{H}-\mathrm{NMR}$ spectrum was set to 9 . The integration of the methyl signal of $\mathbf{3 7}(3 \mathrm{H}, 2.46 \mathrm{ppm})$ was then measured and the following calculation gave the amount of $\mathbf{3 7}$ present.

$(22.25 / 3) \times 10=74 \%$ 


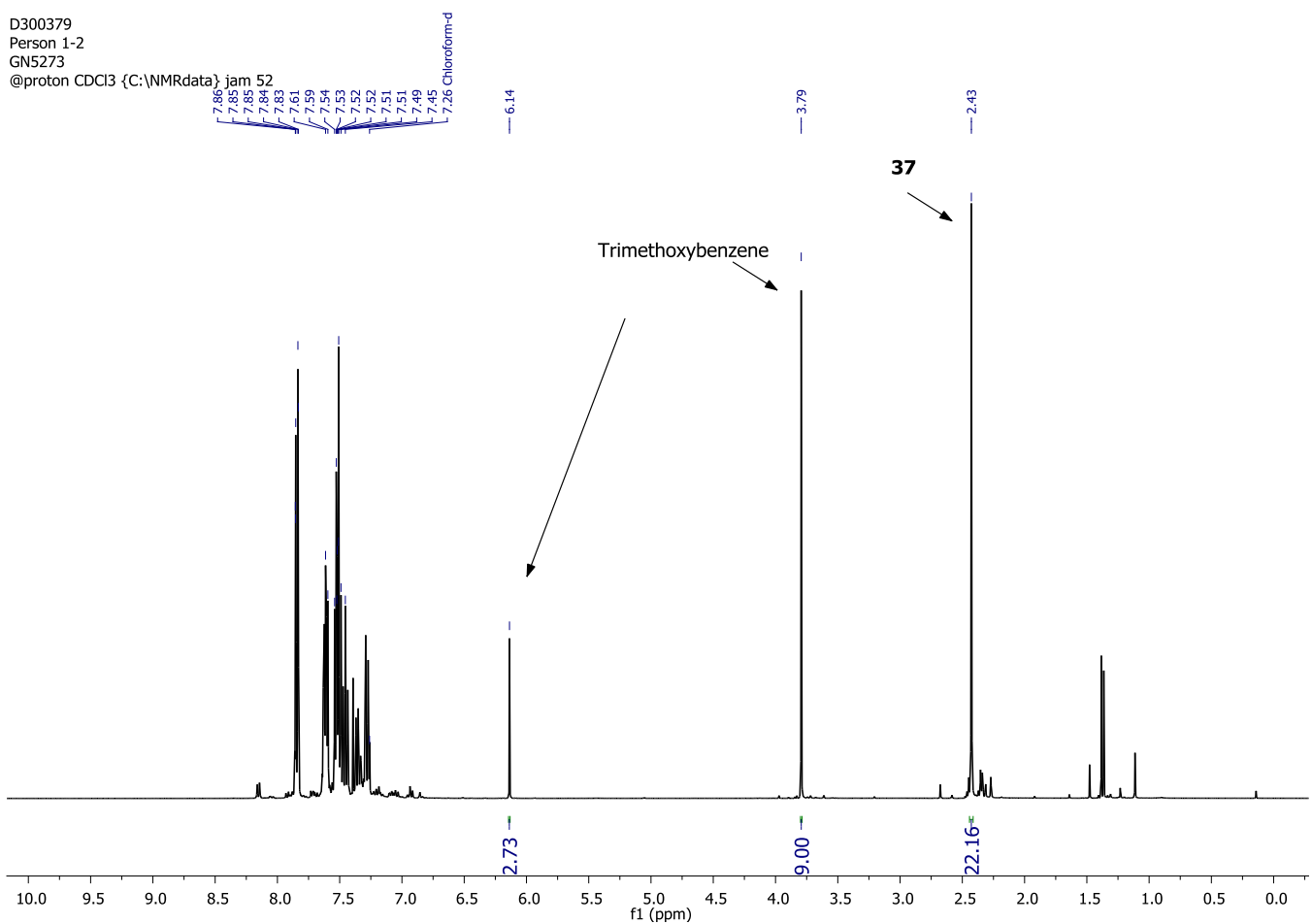

Reactions with iodo- $p$-toluene with no additive (blank reaction)
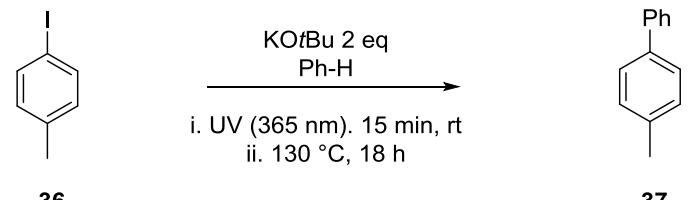

36

37

A mixture of iodo- $p$-toluene $36(0.5 \mathrm{mmol}), \mathrm{KO} t \mathrm{Bu}(112 \mathrm{mg}, 1 \mathrm{mmol})$ in benzene $(2.5 \mathrm{~mL})$ was sealed in a $15 \mathrm{~mL}$ pressure tube in glovebox. The tube was removed from the glovebox and placed RT for 15 min under UV (365 nm) irradiation and then transferred into an oil bath at $130{ }^{\circ} \mathrm{C}$ for $18 \mathrm{~h}$. After cooling to room temperature, the reaction was quenched by water $(15 \mathrm{~mL})$ and acidified with $1 \mathrm{~N} \mathrm{HCl}$ until neutral $\mathrm{pH}$. The mixture was extracted with diethyl ether $(3 \mathrm{x} 15 \mathrm{~mL})$. The organic layer was dried over sodium sulfate, filtered and concentrated to give rise to the residue. 1,3,5-Trimethoxybenzene $8.4 \mathrm{mg},(0.050 \mathrm{mmol}, 10 \mathrm{~mol} \%)$ was added as a solid to the reaction mixture, $\sim 1 \mathrm{~mL} \mathrm{CDCl} 3$ was added and the solution stirred. A portion of the solution was taken and diluted for NMR analysis. The quantity of product was determined as following. For the recovered starting material the integration of methoxy signal (3.81 ppm) of the internal standard in the ${ }^{1} \mathrm{H}-\mathrm{NMR}$ spectrum was set to 9 units. The integration of the methyl signal of $\mathbf{3 6}(3 \mathrm{H}, 2.33 \mathrm{ppm})$ was then measured and the following calculation gave the amount of $\mathbf{3 6}$ present:

$(9.78 / 3) \times 10=33 \%$

For the product 37 the integration of methoxy signal of the internal standard in the ${ }^{1} \mathrm{H}-\mathrm{NMR}$ spectrum was set to 9 units. The integration of the methyl signal of $\mathbf{3 7}(3 \mathrm{H}, 2.46 \mathrm{ppm})$ was then measured and the following calculation gave the amount of 37 present.

$(3.68 / 3) \times 10=12 \%$ 


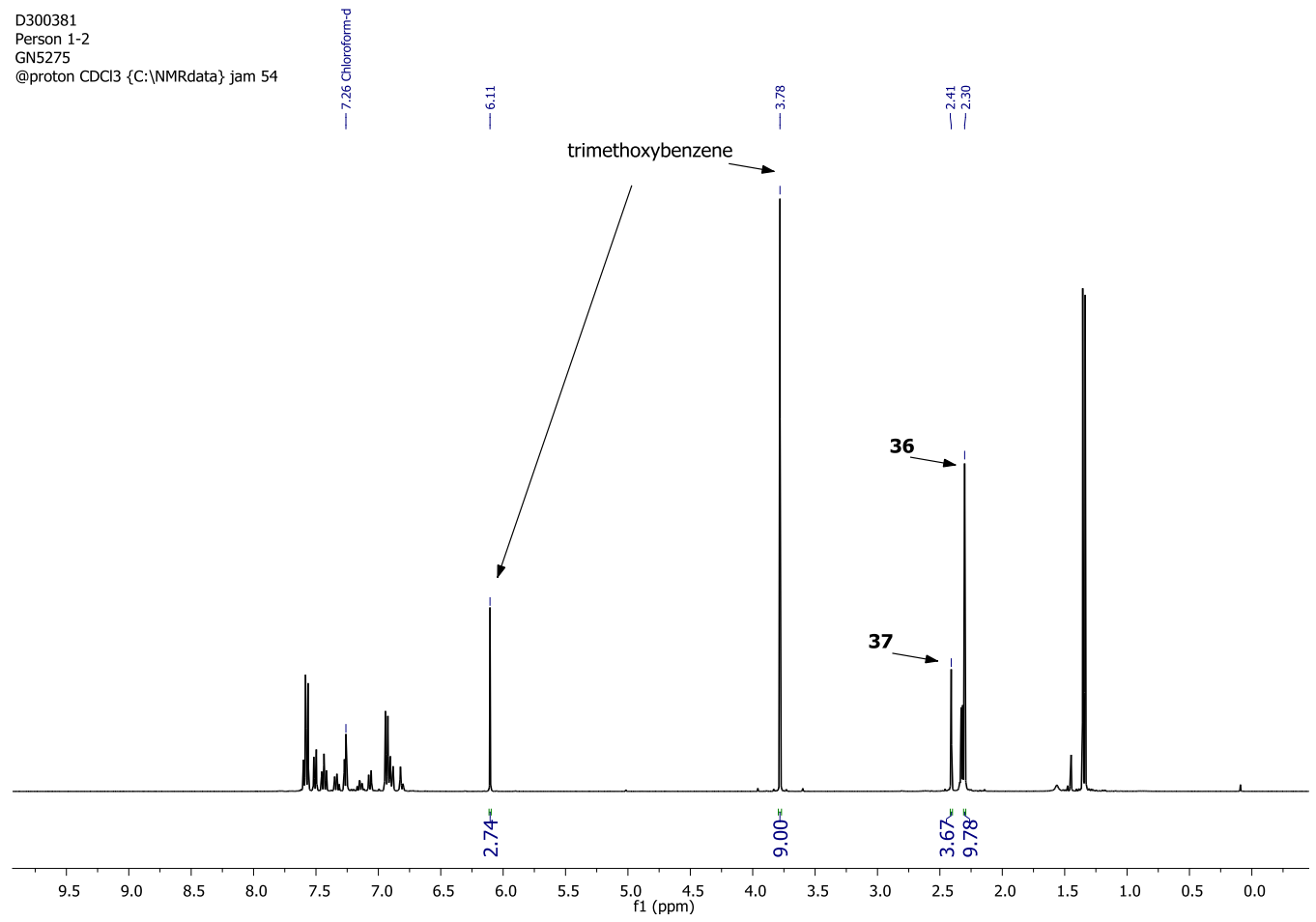

S22 
NMR Spectra:
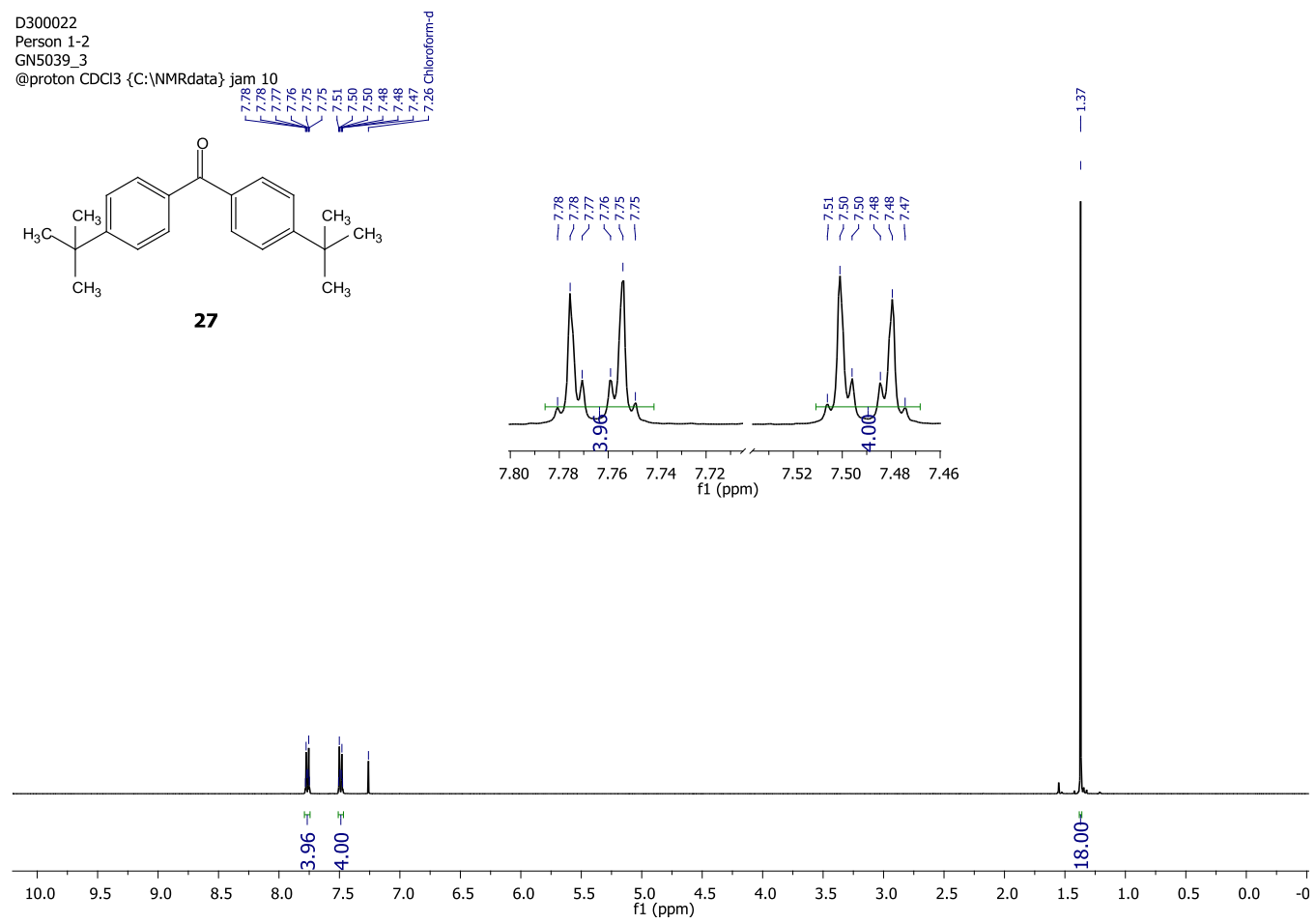

D30\%22

Persên 1-2

13C_@ CDCl3 \{C:|NMRdata $\}$ jam 10

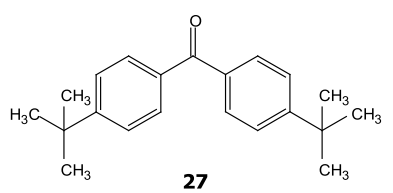

岤

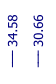

$\stackrel{m}{1}$

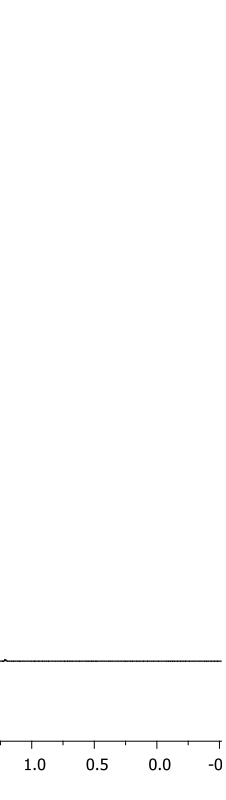

|
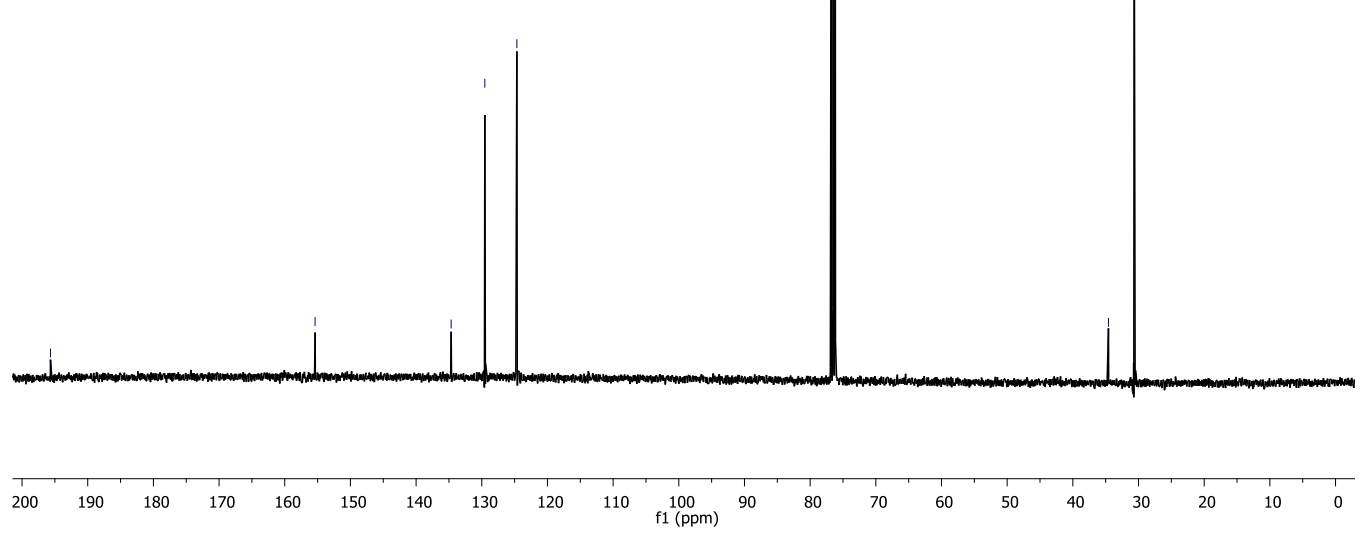

$\mathrm{S} 23$ 

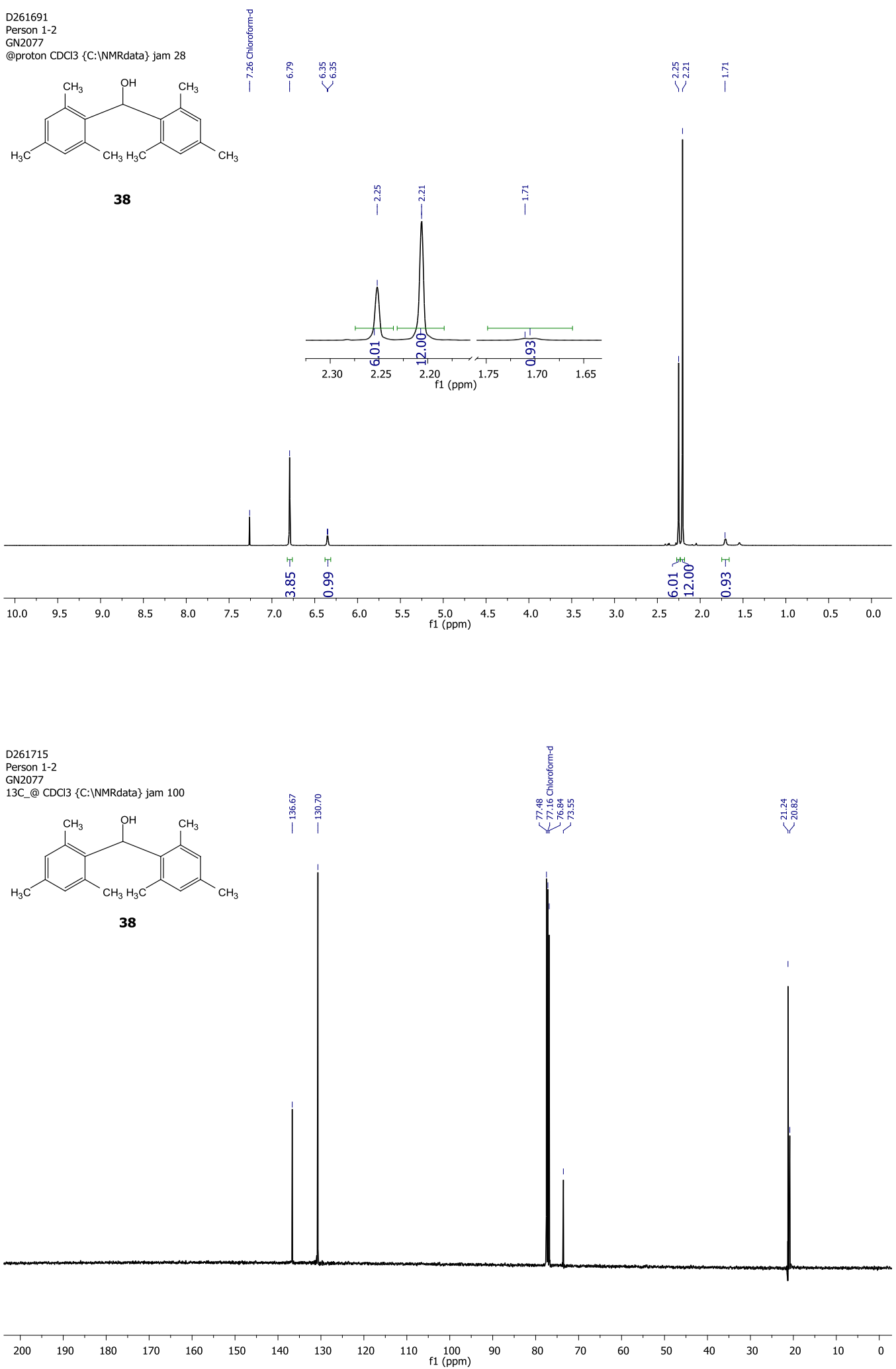


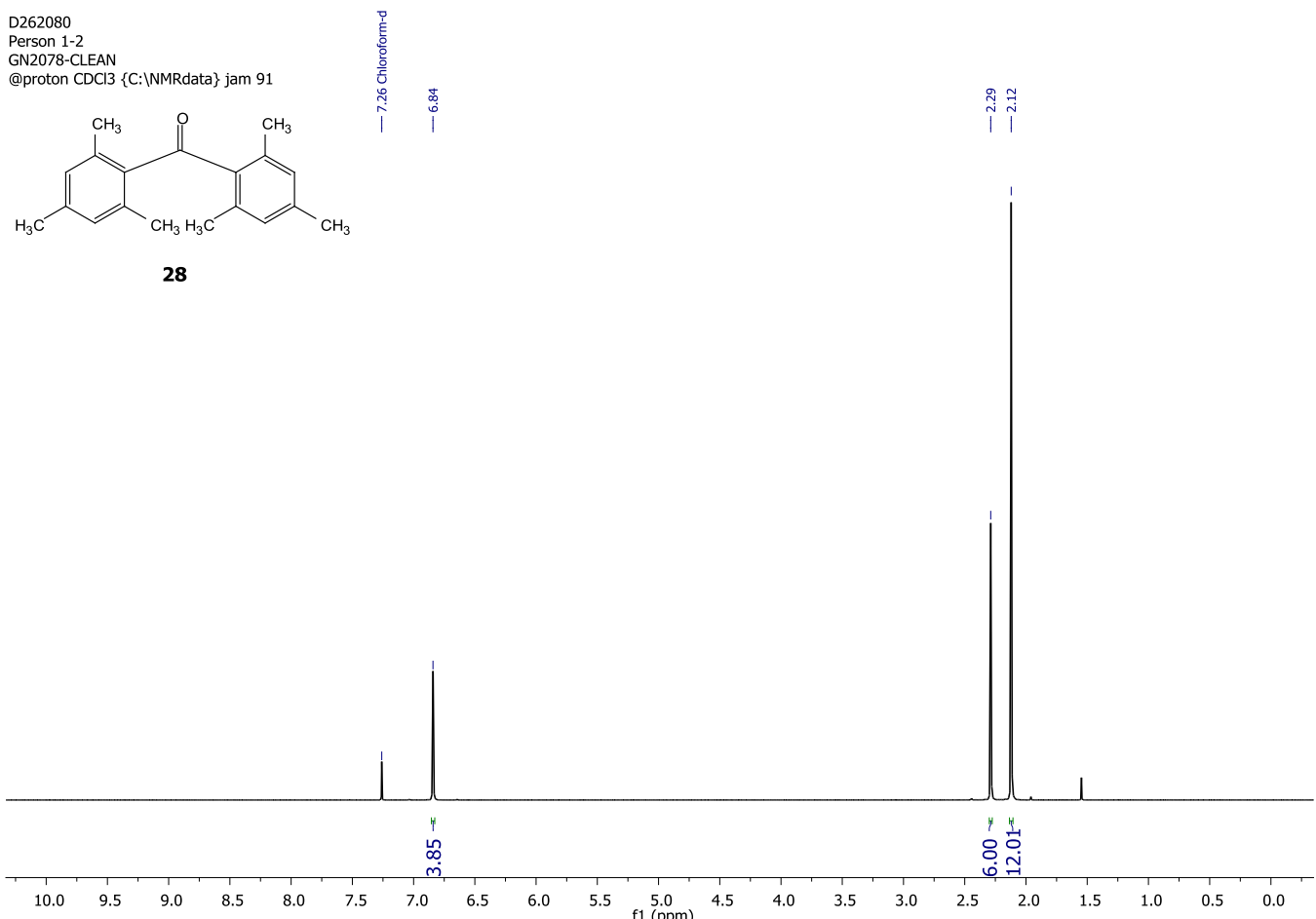

Person $1-2$ 虫

GN2078-CLFAN

13C_@ CDCI3 \{C:INMRdata $\}$ jam 91

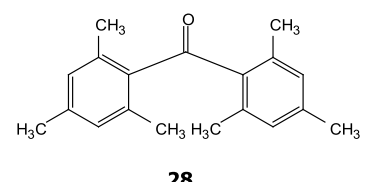

28

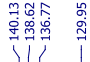

闭

活:

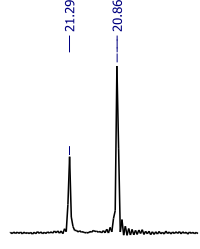

$21.5 \underset{\mathrm{f} 1(\mathrm{ppm})}{21.0} 20.5$

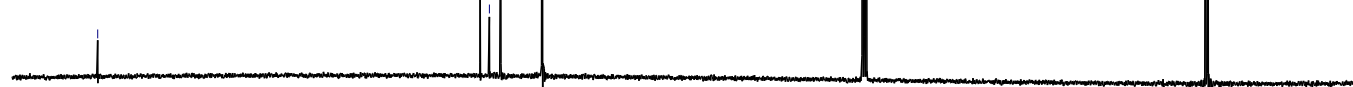

$\begin{array}{lllllllllllllllllllllllll}210 & 200 & 190 & 180 & 170 & 160 & 150 & 140 & 130 & 120 & \underset{\mathrm{f} 1}{110}(\mathrm{ppm}) & 100 & 90 & 80 & 70 & 60 & 50 & 40 & 30 & 20 & 10 & 0\end{array}$ 
D281047

Person 1-2

@proton $\mathrm{CDCl} 3\{\mathrm{C}:$ NMRdata $\}$ jam 3

(a)

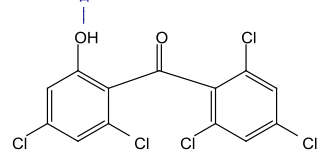

39

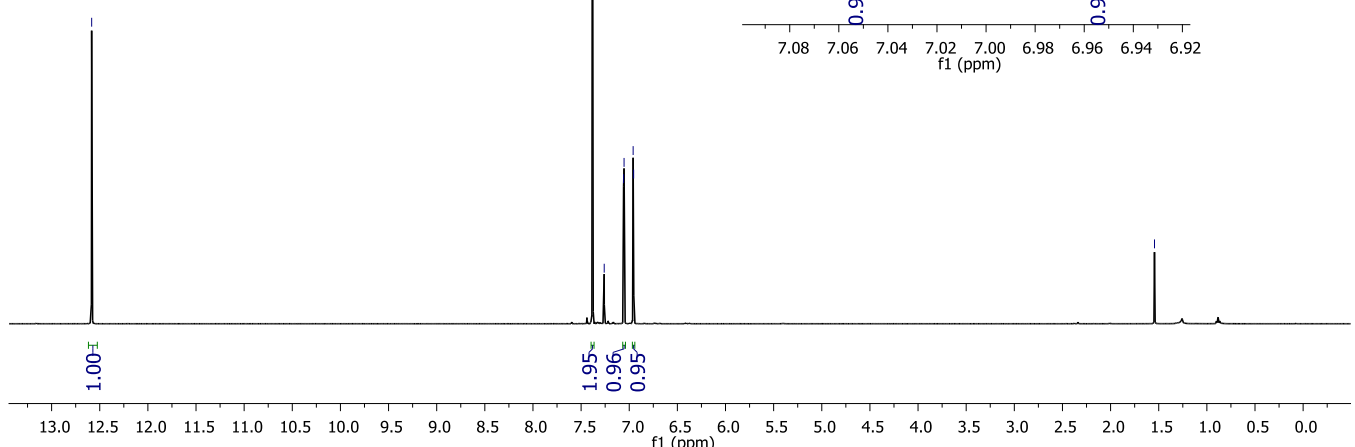

D281 47 Persôn 1-2

13C_@ CDCI3 \{C:|NMRdata\} jam 3

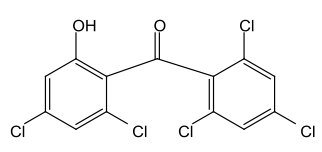

39

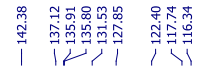

몰

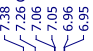

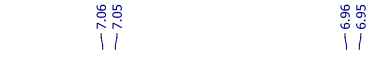

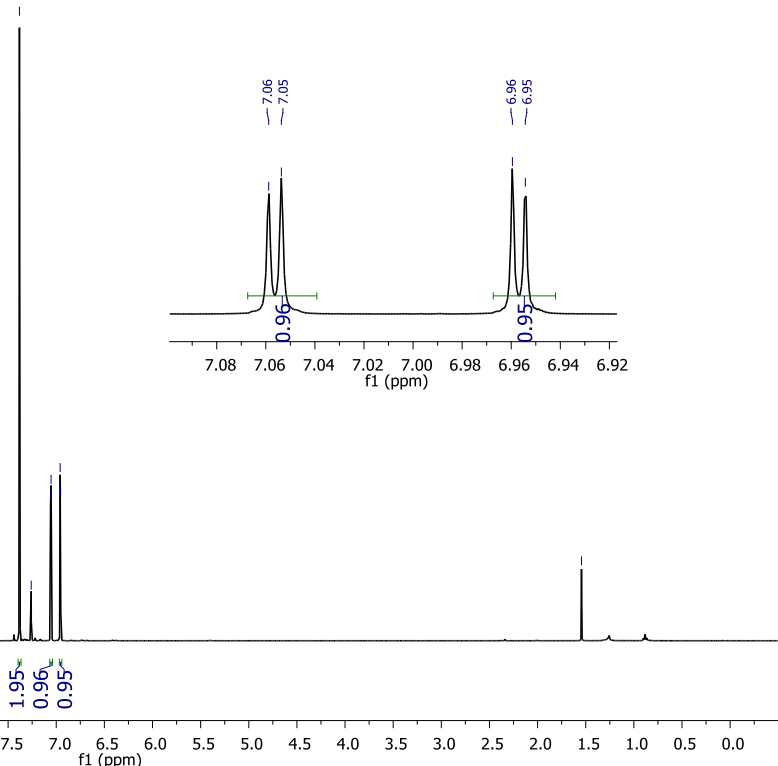

f1 (ppm)

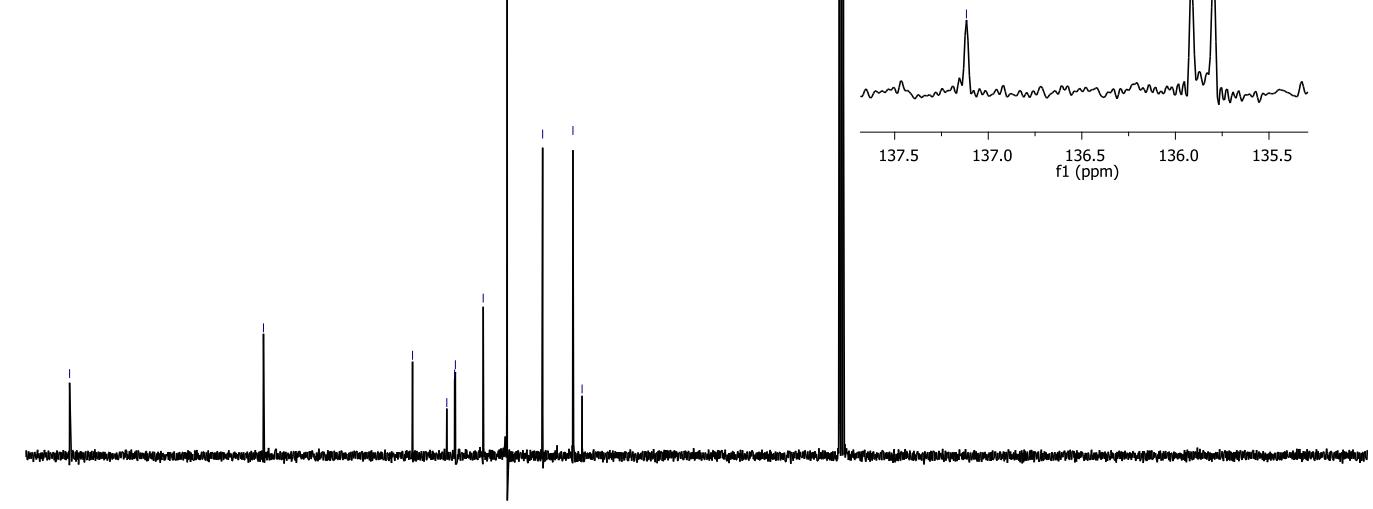

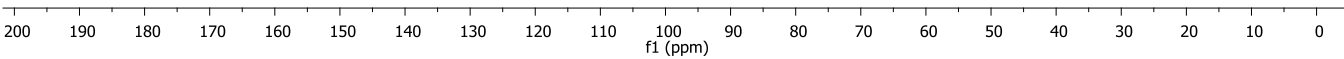




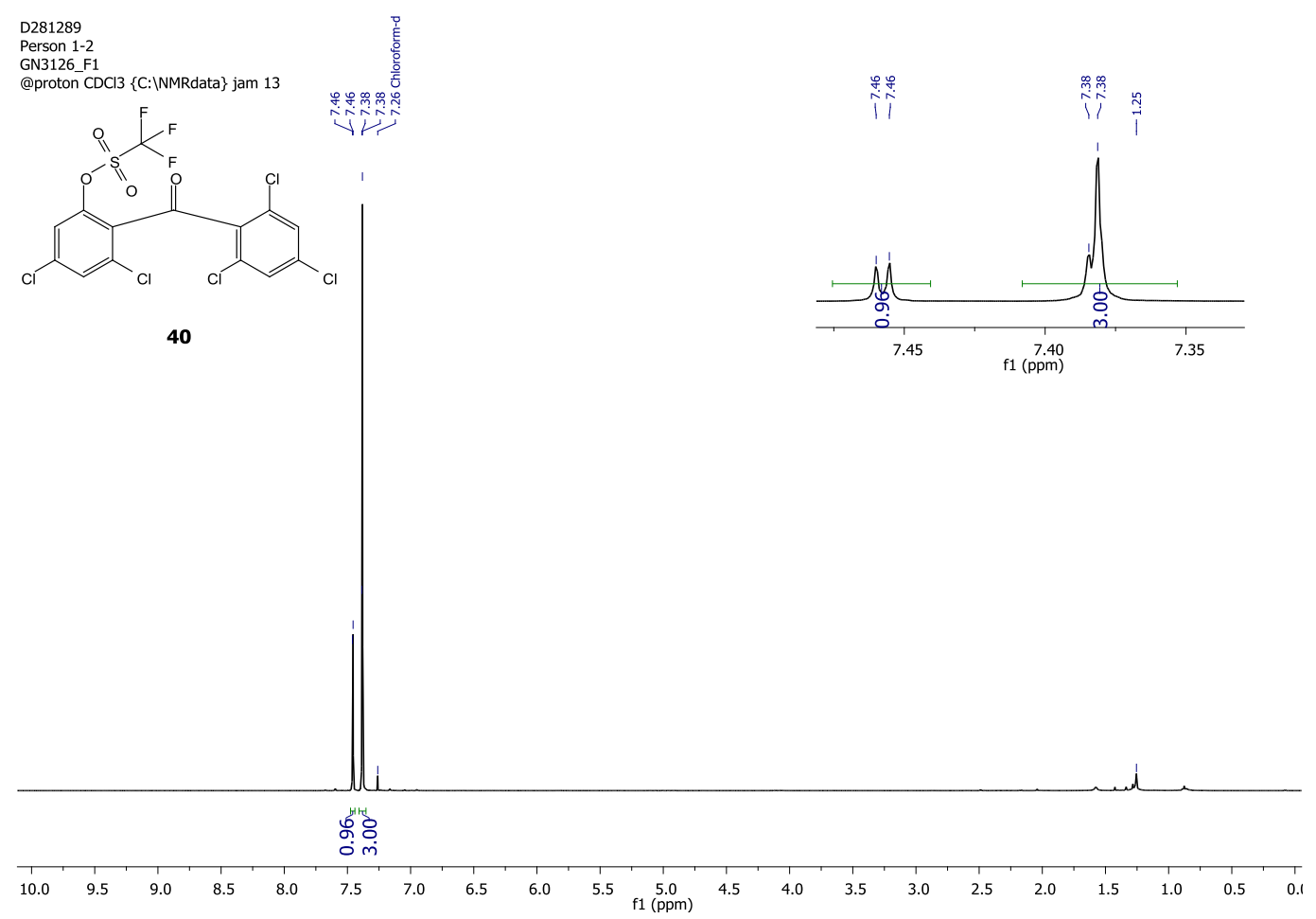

D281289
Person 1-2
GN3126 11

| रोसा 行।

13C_@ CDCl3 \{C:INMRdata $\}$ jam 13
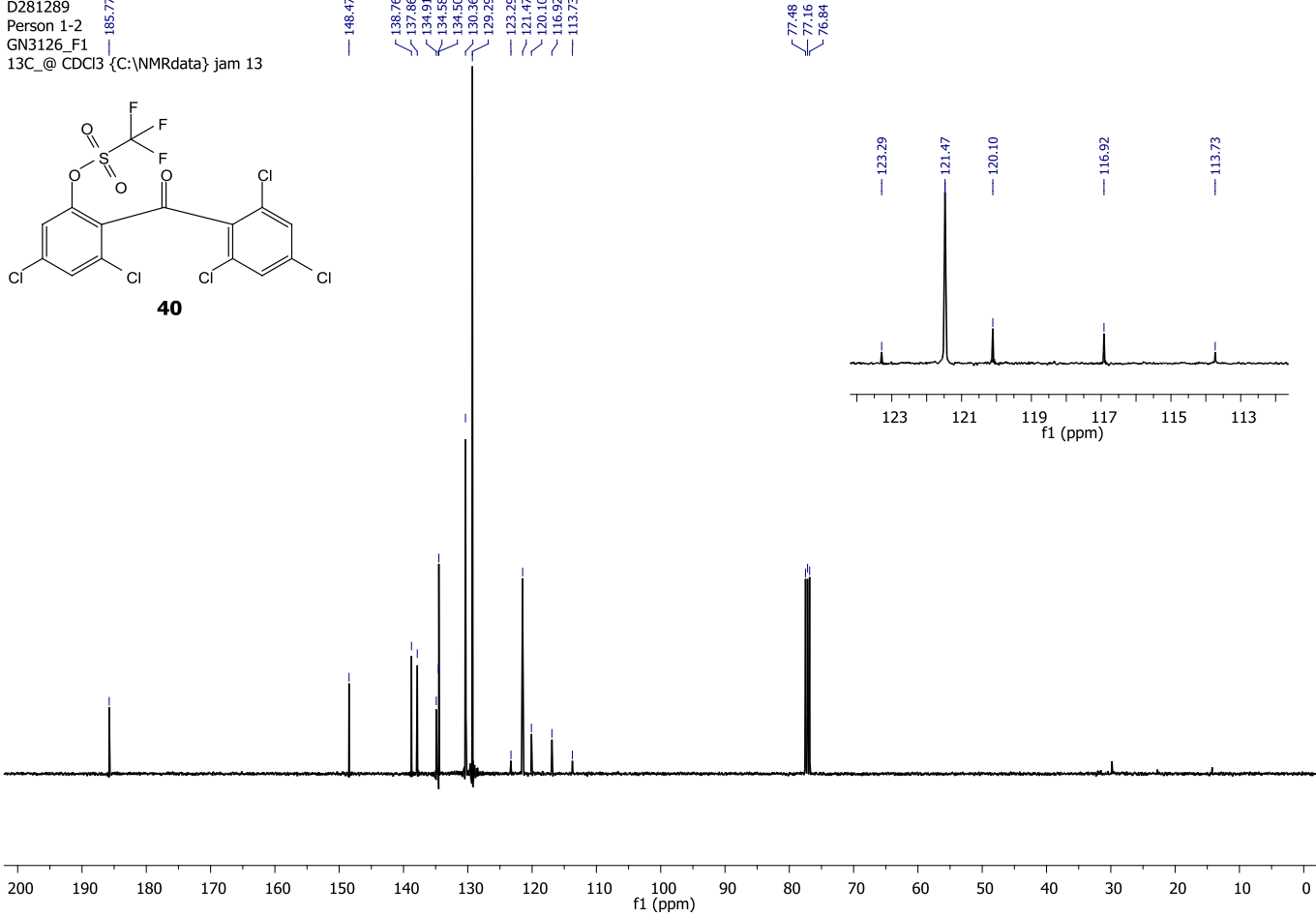

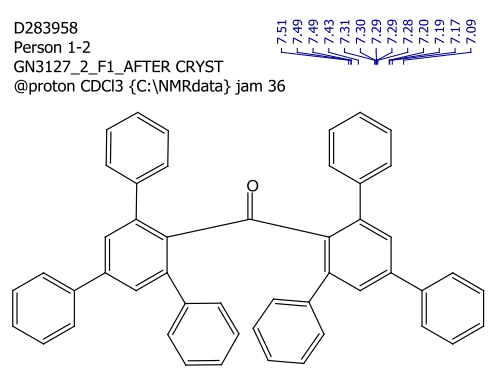

30
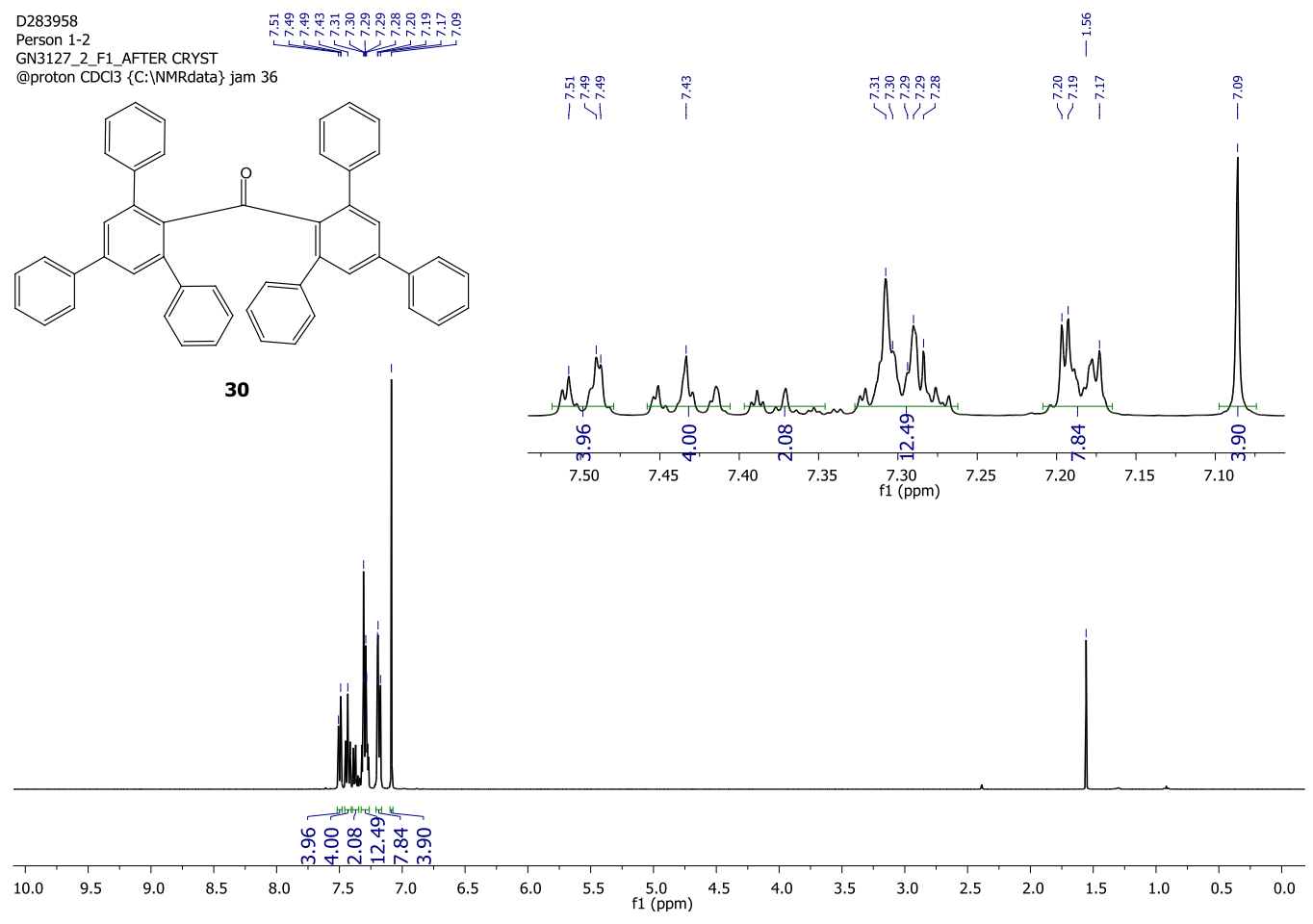

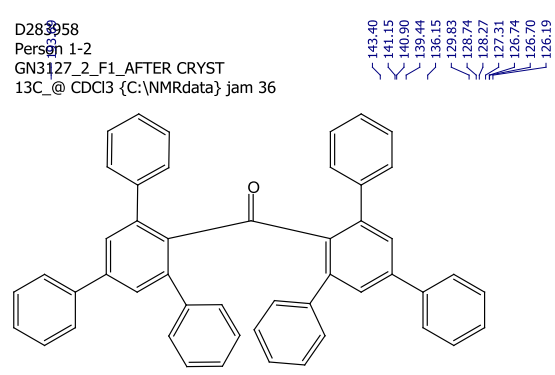

30
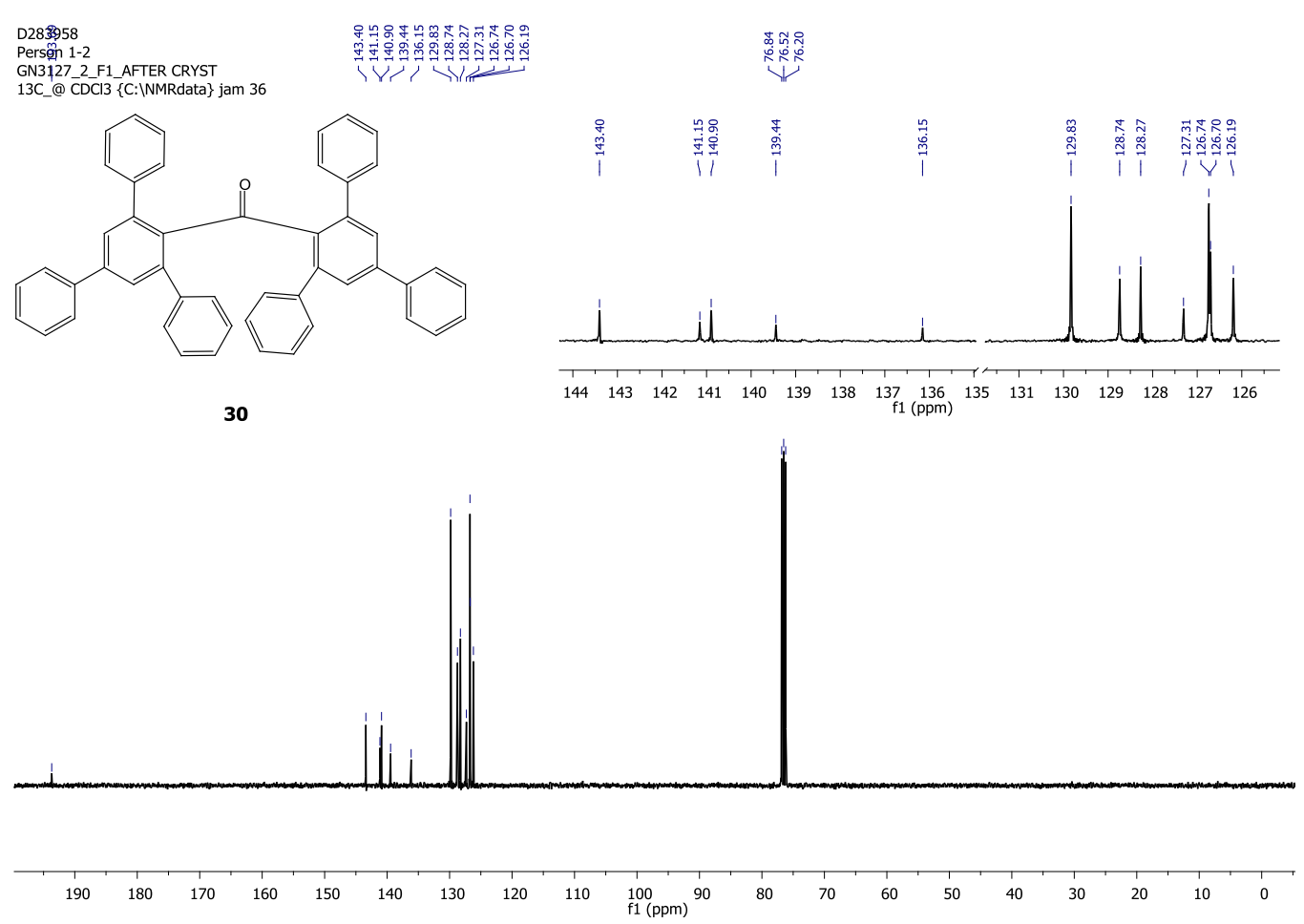

S28 
D284481

GN3128_3_F1

@proton CDCl3 $\{$ \{: $:$ NMRdata $\}$ jam 32

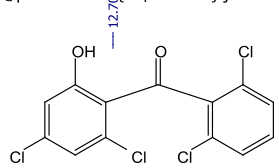

41

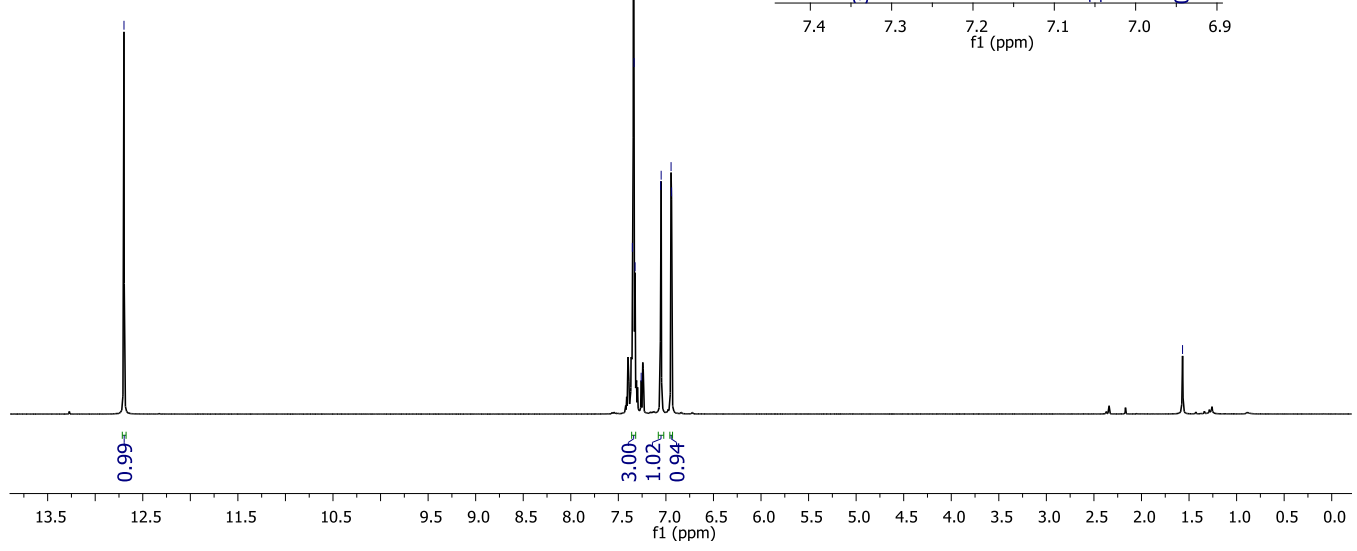

D2844 1

Persorn1-2

| 114 1111

13C@CDCl3 \{C:NMRdata\} jam 32

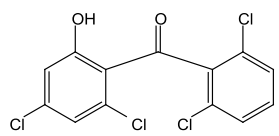

41

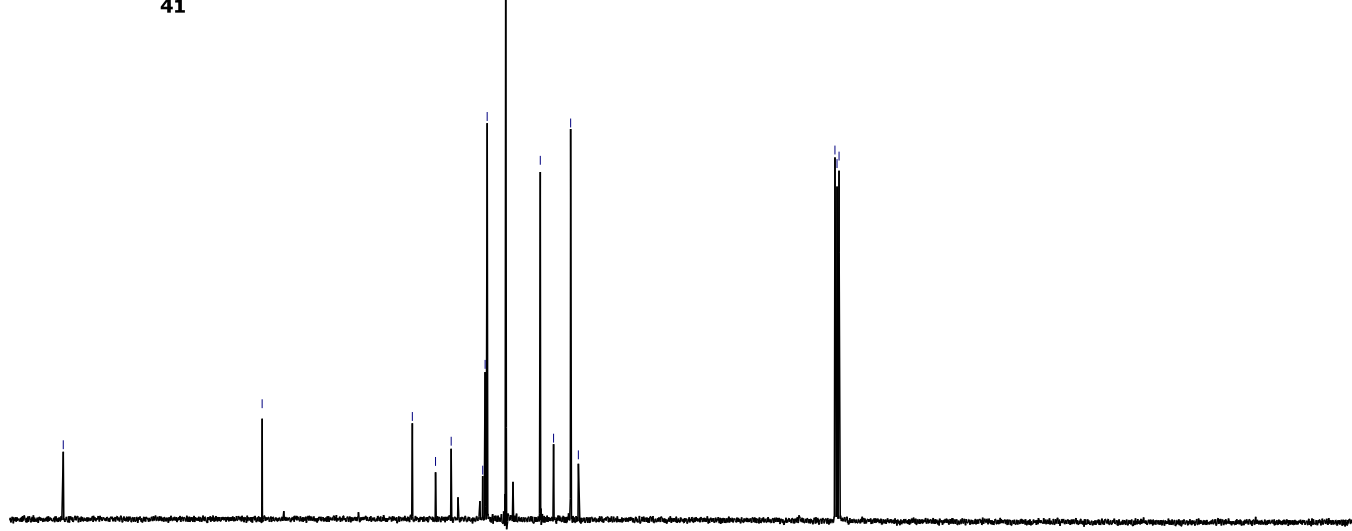

180

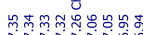

ivitivi

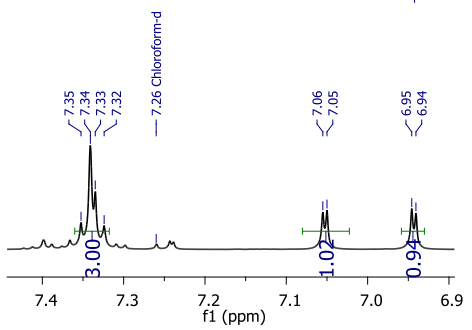

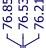

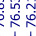



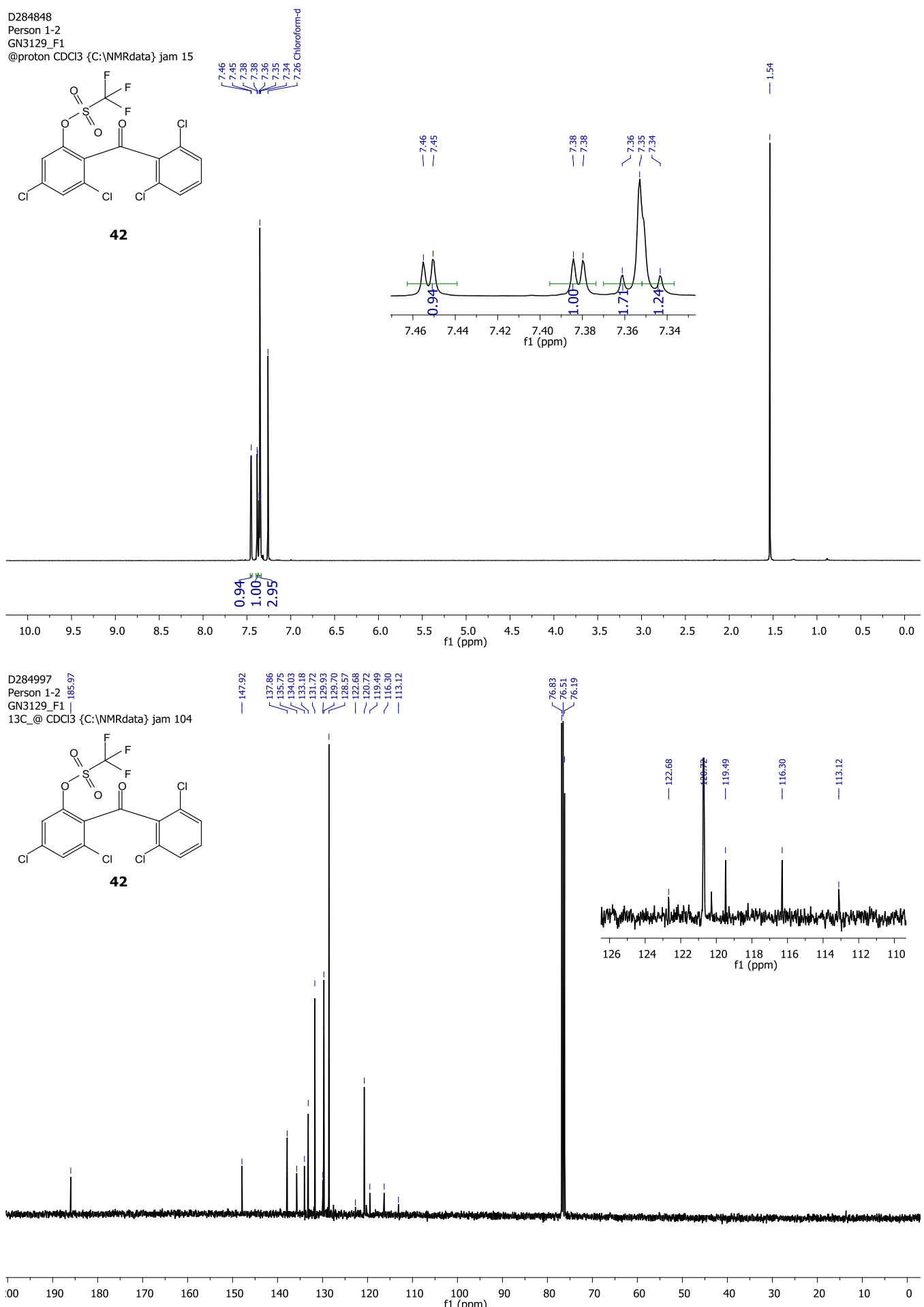

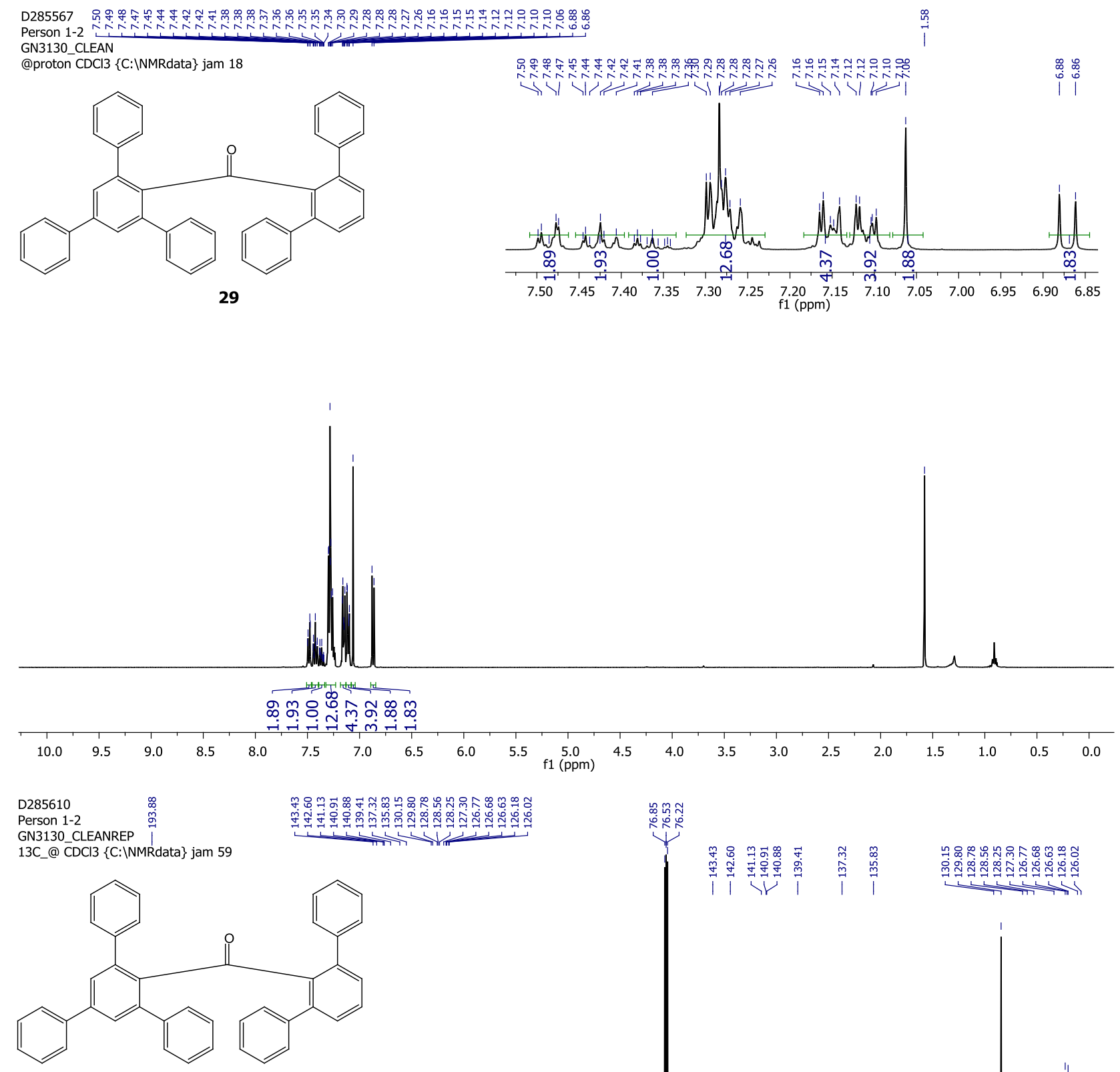

29
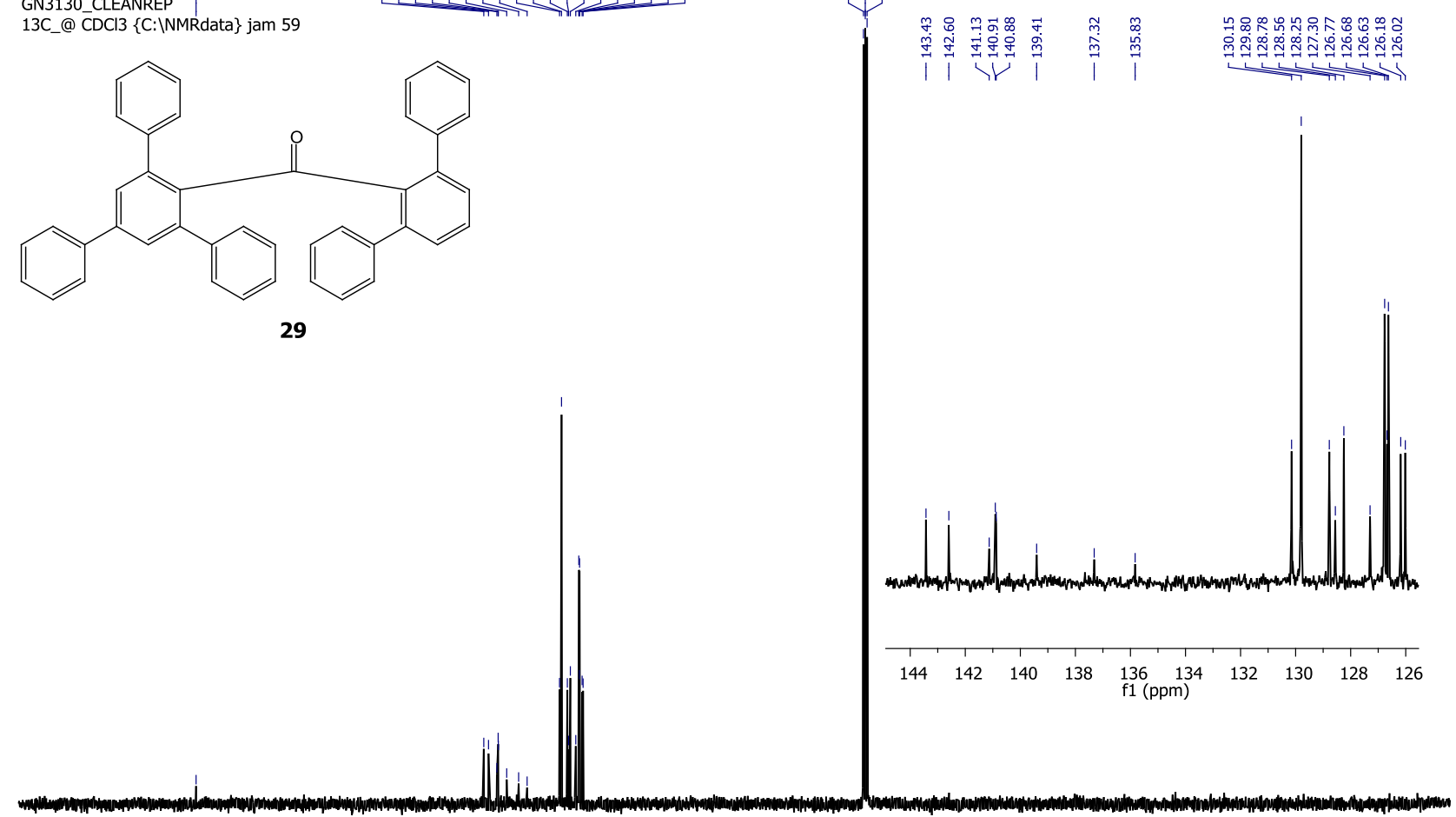

$\begin{array}{lllllllllllllllllllllllll}220 & 210 & 200 & 190 & 180 & 170 & 160 & 150 & 140 & 130 & 120 & 110 & \begin{array}{c}100 \\ \mathrm{f} 1(\mathrm{ppm})\end{array} & 90 & 80 & 70 & 60 & 50 & 40 & 30 & 20 & 10 & 0 & -10 & -20\end{array}$ 


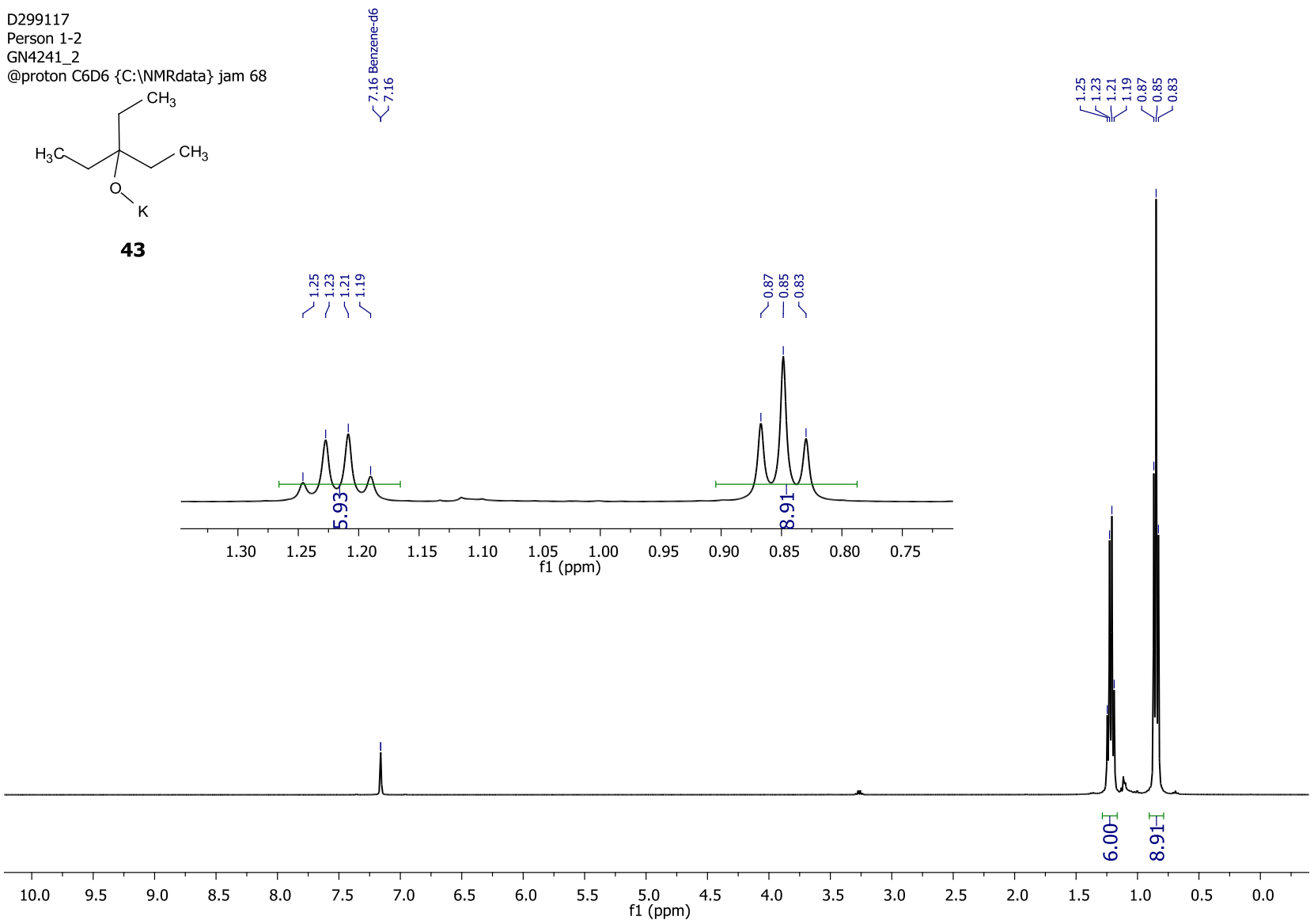

D299117

Person $1-2$

13C_@ C6D6 \{C:|NMRdata $\}$ jam 68

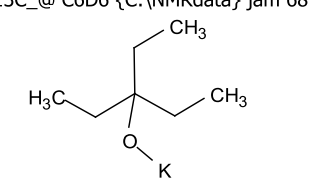

43

\begin{tabular}{|c|c|c|c|c|c|c|c|c|c|c|c|c|c|c|c|c|c|c|c|}
\hline 200 & 190 & 180 & 170 & 160 & 150 & 140 & 130 & 120 & 110 & $\begin{array}{c}100 \\
\mathrm{f} 1(\mathrm{ppm})\end{array}$ & 90 & 80 & 70 & 60 & 50 & 40 & 30 & 20 & 10 \\
\hline
\end{tabular}




\section{Computational Results}

\section{Computational Methods}

Density Functional Theory (DFT) was used for the geometry optimizations of all reactant complexes, transition states, intermediates and product complexes. The final optimized geometries were characterized as minima or transition states by performing frequency calculations, which also enabled calculation of the zero-point energies (ZPE), enthalpies (H), entropies (S) and Gibbs free energies (G) at $298 \mathrm{~K}$. Geometry optimizations and frequency calculations were performed using the Gaussian $09^{9}$ software package, using the M06-2X functional ${ }^{10}$ and $6-31++\mathrm{G}(\mathrm{d}, \mathrm{p})$ basis set, ${ }^{11}$ unless otherwise stated. Implicit solvation was modelled using the Conductor-Like Polarisable Continuum Model (CPCM $)^{12}$ with the associated parameters of THF solvent, unless otherwise stated. Gibbs free energy barriers and relative free energies were calculated between reactant complexes and transition states or reactant complexes and product complexes, respectively and are reported in $\mathrm{kcal} / \mathrm{mol}$ throughout. Time dependent DFT (TD-DFT) ${ }^{13}$ calculations were performed on the M06-2X/6-31++G(d,p) optimised geometries, with the CAM-B3LYP functional, ${ }^{14}$ due to its good performance with intermolecular charge transfer (CT) excitations, ${ }^{15}$ whilst maintaining the $6-31++\mathrm{G}(\mathrm{d}, \mathrm{p})$ basis set and CPCM solvent model.

Naked monomeric tert-butoxide anion is used throughout this work as a simple representation of tetrameric $\mathrm{KO} t \mathrm{Bu}$; see Table S1 where it can be seen that the naked monomer is found to more closely reproduce the thermodynamics of the reaction utilising a $\mathrm{KO} t \mathrm{Bu}$ tetramer, whilst underestimating the kinetics. This approach has also previously been utilised by Grubbs et al.. ${ }^{16-17}$ after having shown that tetramer is the most stable structure in solution by DFT calculations.

\section{Marcus Theory Calculations}

In order to model a single electron transfer reaction computationally, Marcus-Hush Theory ${ }^{18}$ is employed with the 4-point method of Nelsen et al. ${ }^{19}$ or the complexation method of Anderson, Tuttle and co-workers ${ }^{20}$ allowing calculation of the reorganisation energy $(\lambda), \Delta \mathrm{G}_{\text {rel }}$ and $\Delta \mathrm{G}^{*}$. The Nelsen 4-point method requires optimisation of the individual electron donor and acceptor species, before and after single electron transfer. Single point energy calculations are then performed on these optimised geometries using the charge and multiplicity of their other state in the electron transfer reaction. The complexation method requires optimisation of the electron donor and acceptor as a complex in both the reactant and product electronic states. Single point energy calculations are then performed on these optimized geometries with the alternative electronic configuration.

$\underline{\mathrm{KO} t \mathrm{Bu} \text { Representation }}$

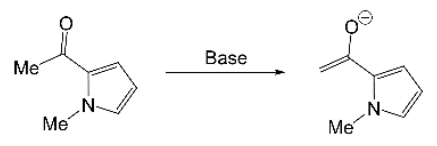

Figure S15. Deprotonation reaction studied using various forms of $\mathrm{KO} t \mathrm{Bu}$.

Table S1. Results of DFT Calculations for the reaction depicted in Figure S1, energies calculated relative to reactant and product complexes. (Computational Method: M06-2X/6-311++G(d,p), CPCM solvation method with parameters for benzene)

$\begin{array}{ccc}\text { Base } & \Delta \mathbf{G}^{*}(\mathbf{K c a l} / \mathbf{m o l}) & \Delta \mathbf{G}_{\mathbf{r e l}}(\mathbf{K c a l} / \mathbf{m o l}) \\ \mathrm{O} t \text { Bu anion } & 0.4 & -12.1 \\ \mathrm{KO} t \mathrm{Bu} \text { monomer } & 4.8 & -4.1 \\ \mathrm{KO} t \mathrm{Bu} \text { dimer } & 7.8 & -3.0 \\ \mathrm{KO} t \mathrm{Bu} \text { tetramer } & 3.9 & -14.5\end{array}$

Feasibility of forming organic electron donors (Scheme 3 (a) main paper)

Given our group's previous evidence showing $\mathrm{KO} t \mathrm{Bu}$ is a poor single electron donor, our initial investigations focused on the possible formation of in situ organic electron donor species resulting from reaction of $\mathrm{KO} t \mathrm{Bu}$ with benzophenone (17). We proposed that tert-butoxide anion might add to the ortho, meta or para positions of a phenyl moiety in benzophenone generating anions 45,47 and 20 , which could then be followed by a deprotonation, generating dianionic species 46,48 and 24. Dianions 46, 48 and 24 have the structural characteristics ${ }^{21}$ to act as electron donors towards benzophenone, should they be accessible.

As shown in Table S2, addition in the meta position has an accessible free energy barrier $(21.1 \mathrm{kcal} / \mathrm{mol})$ but is highly endergonic $(18.6 \mathrm{kcal} / \mathrm{mol})$ thus disfavouring the addition reaction and we therefore disregarded any further reactivity through a meta-adduct. Addition in the ortho and para positions exhibits accessible free energy barriers at the reported 
experimental conditions (room temperature), ${ }^{22-25}$ whilst being endergonic by 5.8 and $5.0 \mathrm{kcal} / \mathrm{mol}$, respectively. Subsequent deprotonation of ortho (45) and para (20) adducts to form dianions $\mathbf{4 6}$ and 24 respectively, occurs with accessible free energy barriers, with both reactions being endergonic $(9.7$ and $7.0 \mathrm{kcal} / \mathrm{mol}$, calculated relative to reactant complex of $\mathbf{4 5}$ or 20 with tert-butoxide anion). Whilst bearing in mind the observation of $3 \%$ benzophenone ketyl radical anion 18, by Ashby et al. these results suggest it is unlikely for even such a small amount of dianionic species such as $\mathbf{4 6}$ or $\mathbf{2 4}$ to be formed $(<<1 \%$ of product would be formed in both addition and deprotonation steps).

Table S2. Calculated Gibbs free energies for addition and deprotonation.

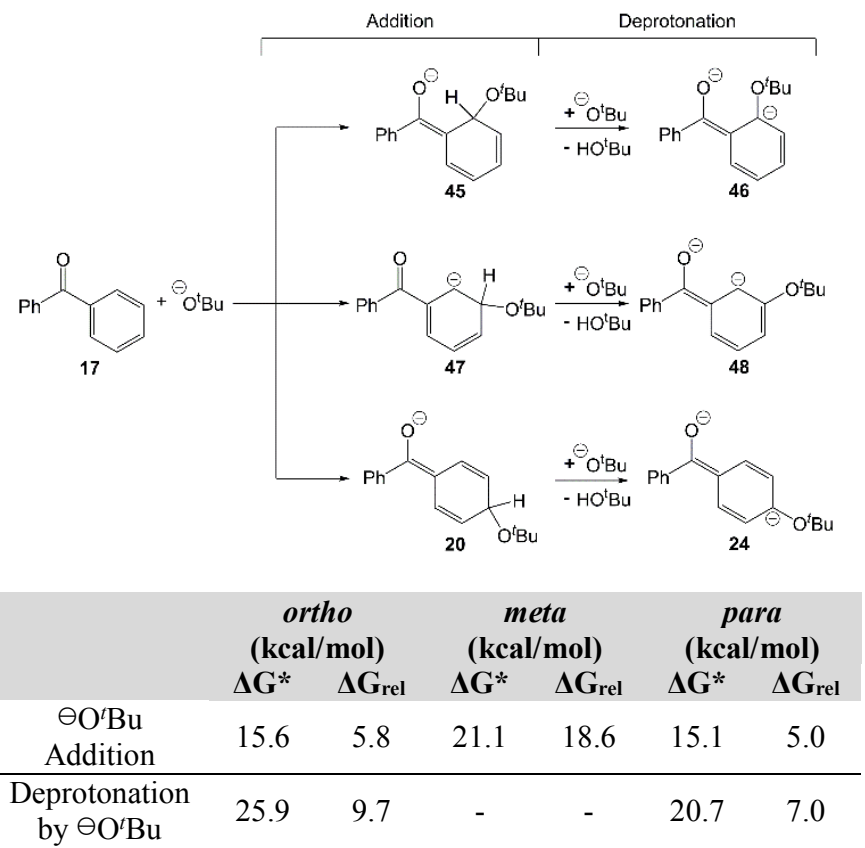

Despite the lack of possibility for forming dianions $\mathbf{4 6}$ and $\mathbf{2 4}$, their ability to act as single electron donors to a molecule of neutral benzophenone was still examined. Marcus Theory calculations were performed to calculate the free energy of activation for SET, as well as the relative free energy, utilising the complexation method of Anderson et al. ${ }^{20}$ and the Nelsen Four Point method. ${ }^{19}$ Marcus Theory calculations utilising the method of Anderson et al. were carried out with and without potassium counter cations (see below for images of optimised complexes), and the results are presented in Table S3.

The calculated low activation energies and exergonic relative energies, from the complexation method, suggest that single electron transfer from a dianionic species such as $\mathbf{4 6}$ or $\mathbf{2 4}$ to benzophenone would occur readily. Results utilising the Nelsen 4-point method are also included and show similar overall exergonic SET reactions, however the predicted activation energy is higher for both $\mathbf{4 6}$ and 24. Previous work in the group has shown the complexation method with counterions to be the most accurate for predicting SET energies, ${ }^{20}$ (however, we include here the Nelsen 4-point results to allow comparison with results from later calculations which require the use of this methodology).

Table S3. Calculated Gibbs free energies for SET from dianions $\mathbf{4 6}$ and $\mathbf{2 4}$ to benzophenone (17).
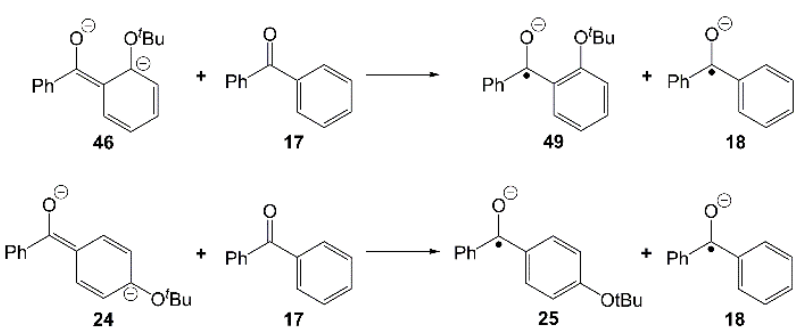

\begin{tabular}{ccc} 
Complexation Method ${ }^{\mathbf{2 0}}$ & $\boldsymbol{\Delta G}^{*}(\mathbf{k c a l} / \mathbf{m o l})$ & $\begin{array}{c}\Delta \mathbf{G}_{\text {rel }} \\
(\mathbf{k c a l} / \mathbf{m o l})\end{array}$ \\
\hline $\mathbf{4 6}+\mathbf{1 7} \rightarrow \mathbf{4 9}+\mathbf{1 8}$ & 0.3 & -20.3 \\
\hline $\begin{array}{c}\mathbf{4 6}+\mathbf{1 7} \rightarrow \mathbf{4 9}+\mathbf{1 8} \\
\text { (with 2 potassium cations) }\end{array}$ & 0.1 & -26.5 \\
\hline $\mathbf{2 4}+\mathbf{1 7} \rightarrow \mathbf{2 5}+\mathbf{1 8}$ & 0.4 & -17.8 \\
\hline $\mathbf{2 4}+\mathbf{1 7} \rightarrow \mathbf{2 5}+\mathbf{1 8}$ & 3.3 & -7.9 \\
\hline \begin{tabular}{c} 
(with 2 potassium cations) \\
\hline
\end{tabular}
\end{tabular}




\begin{tabular}{ccc} 
Nelsen 4-Point Method $^{\mathbf{1 9}}$ & $\boldsymbol{\Delta G}^{*}(\mathbf{k c a l} / \mathbf{m o l})$ & $\begin{array}{c}\Delta \mathbf{G}_{\text {rel }} \\
(\mathbf{k c a l} / \mathbf{m o l})\end{array}$ \\
\hline $\mathbf{4 6}+\mathbf{1 7} \rightarrow \mathbf{4 9}+\mathbf{1 8}$ & 9.1 & -36.7 \\
\hline $\mathbf{2 4}+\mathbf{1 7} \rightarrow \mathbf{2 5}+\mathbf{1 8}$ & 8.3 & -32.9
\end{tabular}

With these results in hand, we wanted to probe alternative mechanisms that could be operating. We therefore investigated the possibility of a hydride transfer from either species $\mathbf{4 5}$ or $\mathbf{2 0}$ to benzophenone, forming $\mathbf{2 1}$. Hydride transfer from anion 45 to benzophenone (17) exhibited an unfavourable free energy barrier of $34.3 \mathrm{kcal} / \mathrm{mol}$ and was slightly exergonic $(0.7$ $\mathrm{kcal} / \mathrm{mol})$, Table S4. On the other hand, anion 20 exhibited a comparable barrier to deprotonation $(22.4 \mathrm{kcal} / \mathrm{mol})$ and was exergonic by $3.8 \mathrm{kcal} / \mathrm{mol}$; these results suggest hydride transfer from $\mathbf{2 0}$ would be possible. In order to achieve an electron donor species from 21 it would be necessary to deprotonate and access dianion 23 (SET from 23 to benzophenone (17) has an activation free energy of $6.9 \mathrm{kcal} / \mathrm{mol}$ and is exergonic by $31.6 \mathrm{kcal} / \mathrm{mol}$, see Figure $\mathbf{S 1 6}$ for results); this exhibits an accessible barrier of $23.0 \mathrm{kcal} / \mathrm{mol}$ whilst being endergonic by $10.2 \mathrm{kcal} / \mathrm{mol}$. The combination of hydride transfer followed by deprotonation of $\mathbf{2 1}$ to form electron donor $\mathbf{2 3}$ can also be dismissed, on the basis of unfavourable kinetics.

Table S4. Calculated Gibbs free energies for hydride transfer from anions 45 and 20 to benzophenone (17) and deprotonation of product 21.
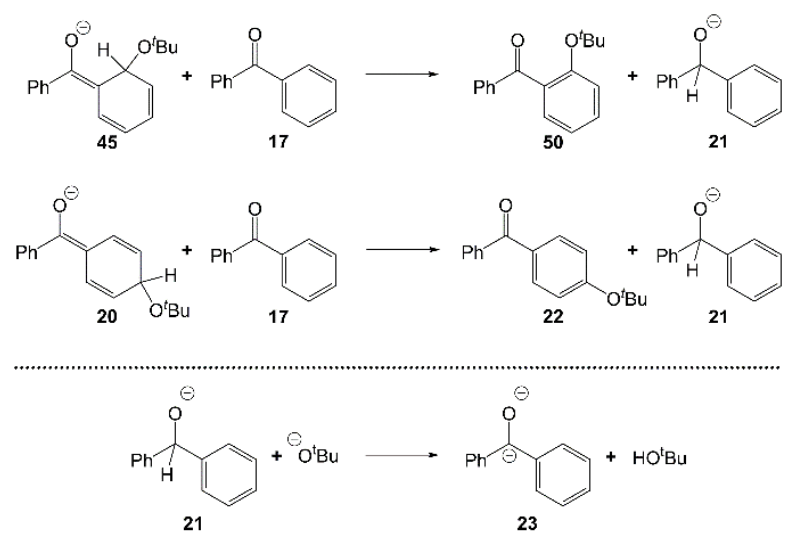

\begin{tabular}{|c|c|c|}
\hline Reaction & $\Delta \mathrm{G}^{*}(\mathrm{kcal} / \mathrm{mol})$ & $\Delta \mathrm{G}_{\text {rel }}(\mathrm{kcal} / \mathrm{mol})$ \\
\hline $45+17 \rightarrow 50+21$ & 34.3 & -0.7 \\
\hline $20+17 \rightarrow 22+21$ & 22.4 & -3.8 \\
\hline $\begin{array}{c}21+\ominus \text { OtBu } \rightarrow 23+ \\
\text { HOtBu }\end{array}$ & 23.0 & 10.2 \\
\hline
\end{tabular}

The above computational data indicates tert-butoxy substitution could not occur; similarly there has been no experimental evidence for formation of such tert-butoxy (or other alkoxy) substituted benzophenone products.

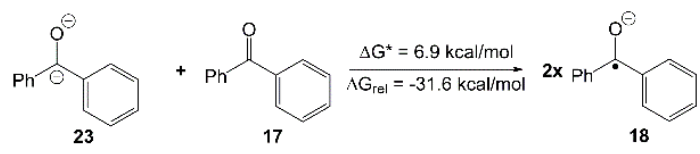

Figure S16. SET from 23 to 17 - Calculated using the Nelsen 4-point method

of this reaction and the ease of reverse reaction we decided not to further probe this as a route to potential electron donor species. 
Benzophenone (17)<smiles>O=C(c1ccccc1)c1ccccc1</smiles>

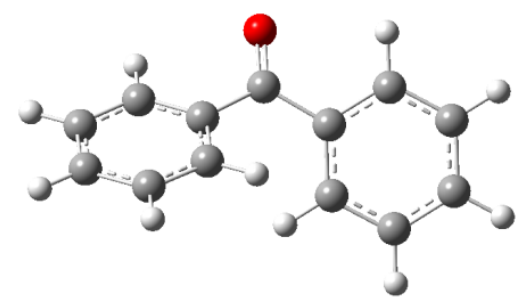

24

$-576.4217964$

$\begin{array}{lrrr}\mathrm{C} & -3.77491 & -0.91946 & 0.13834 \\ \mathrm{C} & -2.66005 & -1.51373 & 0.72891 \\ \mathrm{C} & -1.41870 & -0.88307 & 0.66828 \\ \mathrm{C} & -1.29468 & 0.35659 & 0.03049 \\ \mathrm{C} & -2.42112 & 0.95791 & -0.54344 \\ \mathrm{C} & -3.65452 & 0.31666 & -0.50056 \\ \mathrm{H} & -4.73880 & -1.41734 & 0.17881 \\ \mathrm{H} & -2.75616 & -2.46854 & 1.23558 \\ \mathrm{H} & -0.55385 & -1.34456 & 1.13523 \\ \mathrm{H} & -2.31247 & 1.92559 & -1.02326 \\ \mathrm{H} & -4.52237 & 0.77910 & -0.95960 \\ \mathrm{C} & 0.00001 & 1.10670 & 0.00012 \\ \mathrm{C} & 1.29469 & 0.35658 & -0.03038 \\ \mathrm{C} & 1.41863 & -0.88309 & -0.66815 \\ \mathrm{C} & 2.42119 & 0.95790 & 0.54342 \\ \mathrm{C} & 2.65996 & -1.51377 & -0.72891 \\ \mathrm{H} & 0.55373 & -1.34459 & -1.13500 \\ \mathrm{C} & 3.65458 & 0.31663 & 0.50042 \\ \mathrm{H} & 2.31261 & 1.92559 & 1.02323 \\ \mathrm{C} & 3.77490 & -0.91950 & -0.13847 \\ \mathrm{H} & 2.75601 & -2.46859 & -1.23556 \\ \mathrm{H} & 4.52249 & 0.77908 & 0.95936 \\ \mathrm{H} & 4.73877 & -1.41739 & -0.17902 \\ \mathrm{O} & 0.00001 & 2.32919 & -0.00004\end{array}$

Single Point Radical Anion using Optimised Geometry

17

24

$-576.4969276$

$\begin{array}{llll}\text { C } & -3.77491100 & -0.91946000 & 0.13834000\end{array}$

$\begin{array}{llll}\text { C } & -2.66004800 & -1.51372800 & 0.72891100\end{array}$

$\begin{array}{llll}\text { C } & -1.41869800 & -0.88306600 & 0.66827600\end{array}$

$\begin{array}{lllll}\text { C } & -1.29467500 & 0.35658600 & 0.03049100\end{array}$

$\begin{array}{lllll}\text { C } & -2.42111600 & 0.95791000 & -0.54343500\end{array}$

$\begin{array}{llll}\text { C } & -3.65451800 & 0.31665800 & -0.50055600\end{array}$

$\begin{array}{llll}\mathrm{H} & -4.73879700 & -1.41733800 & 0.17880600\end{array}$

$\mathrm{H} \quad-2.75615900 \quad-2.46854300 \quad 1.23557600$

$\mathrm{H} \quad-\quad-0.55385200 \quad-1.34456400 \quad 1.13522700$

$\mathrm{H} \quad-2.31247100 \quad 1.92559200 \quad-1.02325800$

$\mathrm{H} \quad \begin{array}{llll}\mathrm{H} & -4.52236900 & 0.77910400 & -0.95959900\end{array}$

$\begin{array}{llll}\text { C } & 0.00000900 & 1.10669700 & 0.00012000\end{array}$

$\begin{array}{llll}\text { C } & 1.29468600 & 0.35657700 & -0.03037700\end{array}$

$\begin{array}{llll}\text { C } & 1.41862700 & -0.88308900 & -0.66815100\end{array}$

$\begin{array}{llll}\mathrm{C} & 2.42119400 & 0.95790000 & 0.54341800\end{array}$

$\begin{array}{llll}\mathrm{C} & 2.65996300 & -1.51376800 & -0.72890500\end{array}$

$\begin{array}{lllll}\mathrm{H} & 0.55372600 & -1.34458800 & -1.13499700\end{array}$

$\begin{array}{llll}\mathrm{C} & 3.65458400 & 0.31663200 & 0.50042000\end{array}$

$\begin{array}{llll}\mathrm{H} & 2.31261200 & 1.92559200 & 1.02323500\end{array}$

$\begin{array}{llll}\mathrm{C} & 3.77489600 & -0.91949800 & -0.13846700\end{array}$

$\mathrm{H} \quad \begin{array}{llll}\mathrm{H} & 2.75600900 & -2.46859300 & -1.23556100\end{array}$

$\begin{array}{llll}\mathrm{H} & 4.52248800 & 0.77907700 & 0.95936400\end{array}$ 


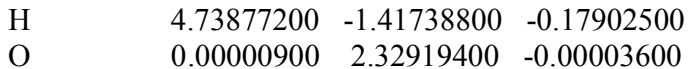

Benzophenone Radical Anion (18)<smiles>[O-]C(c1ccccc1)c1ccccc1</smiles>

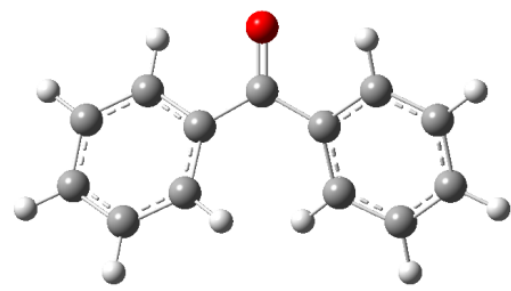

24 $-576.5066700$

$\begin{array}{lrrr}\mathrm{C} & 3.87258 & -0.87217 & -0.07837 \\ \mathrm{C} & 2.74326 & -1.58592 & -0.49682 \\ \mathrm{C} & 1.47967 & -1.00708 & -0.46971 \\ \mathrm{C} & 1.28461 & 0.32117 & -0.01271 \\ \mathrm{C} & 2.44758 & 1.03748 & 0.36951 \\ \mathrm{C} & 3.70662 & 0.45123 & 0.34648 \\ \mathrm{H} & 4.85658 & -1.33022 & -0.09921 \\ \mathrm{H} & 2.85244 & -2.60291 & -0.86540 \\ \mathrm{H} & 0.63747 & -1.57669 & -0.84842 \\ \mathrm{H} & 2.32393 & 2.06687 & 0.68988 \\ \mathrm{H} & 4.57160 & 1.03022 & 0.66107 \\ \mathrm{C} & 0.00000 & 1.02918 & 0.00001 \\ \mathrm{C} & -1.28461 & 0.32117 & 0.01272 \\ \mathrm{C} & -1.47968 & -1.00708 & 0.46972 \\ \mathrm{C} & -2.44758 & 1.03748 & -0.36951 \\ \mathrm{C} & -2.74327 & -1.58592 & 0.49682 \\ \mathrm{H} & -0.63748 & -1.57669 & 0.84844 \\ \mathrm{C} & -3.70661 & 0.45123 & -0.34649 \\ \mathrm{H} & -2.32392 & 2.06687 & -0.68988 \\ \mathrm{C} & -3.87258 & -0.87216 & 0.07835 \\ \mathrm{H} & -2.85245 & -2.60291 & 0.86540 \\ \mathrm{H} & -4.57159 & 1.03023 & -0.66109 \\ \mathrm{H} & -4.85658 & -1.33021 & 0.09919 \\ \mathrm{O} & 0.00000 & 2.31424 & -0.00000\end{array}$


Single Point Singlet using

Optimised Geometry

Benzophenone Radical Anion

24

$-576.4126038$

$\begin{array}{lrrr}\mathrm{C} & 3.87257800 & -0.87216700 & -0.07836500 \\ \mathrm{C} & 2.74326400 & -1.58592400 & -0.49682400 \\ \mathrm{C} & 1.47967100 & -1.00708400 & -0.46970900 \\ \mathrm{C} & 1.28460700 & 0.32116900 & -0.01271100 \\ \mathrm{C} & 2.44758200 & 1.03748100 & 0.36951200 \\ \mathrm{C} & 3.70661900 & 0.45122700 & 0.34647600 \\ \mathrm{H} & 4.85658400 & -1.33021700 & -0.09921400 \\ \mathrm{H} & 2.85244400 & -2.60290900 & -0.86539600 \\ \mathrm{H} & 0.63747300 & -1.57669300 & -0.84842200 \\ \mathrm{H} & 2.32392700 & 2.06687100 & 0.68988000 \\ \mathrm{H} & 4.57159700 & 1.03022500 & 0.66106700 \\ \mathrm{C} & 0.00000100 & 1.02918100 & 0.00001100 \\ \mathrm{C} & -1.28460700 & 0.32116900 & 0.01272300 \\ \mathrm{C} & -1.47967500 & -1.00708300 & 0.46972000 \\ \mathrm{C} & -2.44757700 & 1.03748100 & -0.36951200 \\ \mathrm{C} & -2.74326900 & -1.58592200 & 0.49682300 \\ \mathrm{H} & -0.63748100 & -1.57669200 & 0.84844200 \\ \mathrm{C} & -3.70661400 & 0.45122900 & -0.34648800 \\ \mathrm{H} & -2.32391800 & 2.06687200 & -0.68988000 \\ \mathrm{C} & -3.87257900 & -0.87216500 & 0.07835200 \\ \mathrm{H} & -2.85245300 & -2.60290600 & 0.86539500 \\ \mathrm{H} & -4.57158900 & 1.03022700 & -0.66108900 \\ \mathrm{H} & -4.85658500 & -1.33021400 & 0.09919300 \\ \mathrm{O} & 0.00000000 & 2.31423600 & -0.00000200\end{array}$

Single Point Dianion using

Optimised Geometry

Benzophenone Radical Anion

24

$-576.5350689$

$\begin{array}{lrrr}\mathrm{C} & 3.87257800 & -0.87216700 & -0.07836500 \\ \mathrm{C} & 2.74326400 & -1.58592400 & -0.49682400 \\ \mathrm{C} & 1.47967100 & -1.00708400 & -0.46970900 \\ \mathrm{C} & 1.28460700 & 0.32116900 & -0.01271100 \\ \mathrm{C} & 2.44758200 & 1.03748100 & 0.36951200 \\ \mathrm{C} & 3.70661900 & 0.45122700 & 0.34647600 \\ \mathrm{H} & 4.85658400 & -1.33021700 & -0.09921400 \\ \mathrm{H} & 2.85244400 & -2.60290900 & -0.86539600 \\ \mathrm{H} & 0.63747300 & -1.57669300 & -0.84842200 \\ \mathrm{H} & 2.32392700 & 2.06687100 & 0.68988000 \\ \mathrm{H} & 4.57159700 & 1.03022500 & 0.66106700 \\ \mathrm{C} & 0.00000100 & 1.02918100 & 0.00001100 \\ \mathrm{C} & -1.28460700 & 0.32116900 & 0.01272300 \\ \mathrm{C} & -1.47967500 & -1.00708300 & 0.46972000 \\ \mathrm{C} & -2.44757700 & 1.03748100 & -0.36951200 \\ \mathrm{C} & -2.74326900 & -1.58592200 & 0.49682300 \\ \mathrm{H} & -0.63748100 & -1.57669200 & 0.84844200 \\ \mathrm{C} & -3.70661400 & 0.45122900 & -0.34648800 \\ \mathrm{H} & -2.32391800 & 2.06687200 & -0.68988000 \\ \mathrm{C} & -3.87257900 & -0.87216500 & 0.07835200 \\ \mathrm{H} & -2.85245300 & -2.60290600 & 0.86539500 \\ \mathrm{H} & -4.57158900 & 1.03022700 & -0.66108900 \\ \mathrm{H} & -4.85658500 & -1.33021400 & 0.09919300 \\ \mathrm{O} & 0.00000000 & 2.31423600 & -0.00000200\end{array}$


tert-Butoxide Anion
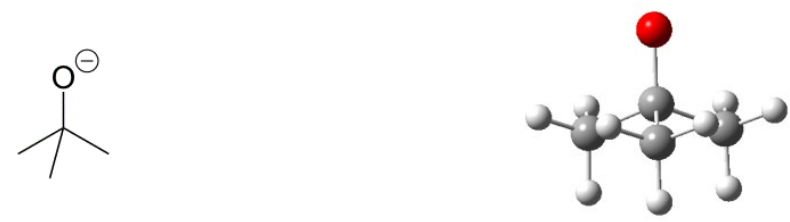

14 $-233.0544325$

$\begin{array}{lrrr}\mathrm{C} & 1.44067 & -0.06139 & -0.43463 \\ \mathrm{C} & 0.00048 & -0.00003 & 0.12965 \\ \mathrm{H} & 2.01123 & 0.80195 & -0.07121 \\ \mathrm{H} & 1.93541 & -0.97065 & -0.07217 \\ \mathrm{H} & 1.47391 & -0.06232 & -1.53300 \\ \mathrm{C} & -0.77523 & -1.21695 & -0.43101 \\ \mathrm{C} & -0.66855 & 1.27897 & -0.43026 \\ \mathrm{H} & -1.80900 & -1.19007 & -0.06549 \\ \mathrm{H} & -0.79611 & -1.24637 & -1.52932 \\ \mathrm{H} & -0.31234 & -2.14272 & -0.06828 \\ \mathrm{H} & -0.68742 & 1.30985 & -1.52855 \\ \mathrm{H} & -1.70061 & 1.34069 & -0.06418 \\ \mathrm{H} & -0.12759 & 2.16163 & -0.06827 \\ \mathrm{O} & 0.00353 & -0.00071 & 1.49975\end{array}$

tert-Butanol $\left(\mathrm{HO}^{t} \mathrm{Bu}\right)$<smiles>CC(C)(C)O</smiles>

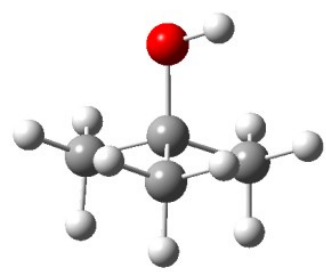

15 $-233.5806428$

$\begin{array}{lccc}\mathrm{C} & -1.49270 & -0.00002 & -0.31732 \\ \mathrm{C} & -0.00606 & 0.00000 & 0.01498 \\ \mathrm{H} & -1.97347 & -0.88876 & 0.10226 \\ \mathrm{H} & -1.97350 & 0.88872 & 0.10223 \\ \mathrm{H} & -1.64200 & -0.00005 & -1.40068 \\ \mathrm{C} & 0.67162 & 1.25791 & -0.52689 \\ \mathrm{C} & 0.67166 & -1.25789 & -0.52689 \\ \mathrm{H} & 1.73360 & 1.27098 & -0.25667 \\ \mathrm{H} & 0.59949 & 1.29843 & -1.61812 \\ \mathrm{H} & 0.19631 & 2.15130 & -0.11123 \\ \mathrm{H} & 0.59956 & -1.29840 & -1.61812 \\ \mathrm{H} & 1.73363 & -1.27094 & -0.25665 \\ \mathrm{H} & 0.19636 & -2.15130 & -0.11124 \\ \mathrm{O} & 0.05936 & 0.00000 & 1.44873 \\ \mathrm{H} & 0.98799 & 0.00002 & 1.71513\end{array}$


Reactant Complex for formation of $\mathbf{4 5}$ from $\mathbf{1 7}$ and $\mathrm{O} t \mathrm{Bu}$ anion

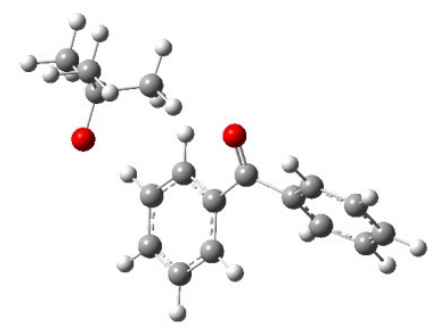

38

$-809.4818830$

$\begin{array}{llll}\text { C } & 5.75012 & -0.43125 & 0.87668\end{array}$

$\begin{array}{llll}\mathrm{C} & 4.74081 & 0.27793 & 1.52733\end{array}$

$\begin{array}{llll}\mathrm{C} & 3.43543 & 0.24017 & 1.03985\end{array}$

$\begin{array}{llll}\text { C } & 3.13285 & -0.52599 & -0.09143\end{array}$

$\begin{array}{llll}\text { C } & 4.14609 & -1.25151 & -0.72891\end{array}$

$\begin{array}{lllll}\text { C } & 5.45254 & -1.19473 & -0.25437\end{array}$

$\begin{array}{llll}\mathrm{H} & 6.76811 & -0.39192 & 1.25185\end{array}$

$\begin{array}{llll}\mathrm{H} & 4.96966 & 0.86115 & 2.41343\end{array}$

$\begin{array}{llll}\mathrm{H} & 2.64934 & 0.78691 & 1.55171\end{array}$

$\begin{array}{llll}\mathrm{H} & 3.89440 & -1.85102 & -1.59820\end{array}$

$\begin{array}{llll}\mathrm{H} & 6.23842 & -1.74576 & -0.76103\end{array}$

$\begin{array}{llll}\text { C } & 1.73281 & -0.65782 & -0.60991\end{array}$

$\begin{array}{llll}\mathrm{C} & 0.78155 & 0.48671 & -0.48134\end{array}$

$\begin{array}{llll}\mathrm{C} & 1.21869 & 1.81657 & -0.52179\end{array}$

$\begin{array}{llll}\text { C } & -0.58800 & 0.20876 & -0.38002\end{array}$

$\begin{array}{llll}\mathrm{C} & 0.28886 & 2.85304 & -0.46424\end{array}$

$\begin{array}{llll}\mathrm{H} & 2.27664 & 2.04065 & -0.62171\end{array}$

$\begin{array}{llll}\mathrm{C} & -1.52047 & 1.24045 & -0.29914\end{array}$

$\begin{array}{llll}\mathrm{H} & -0.90924 & -0.82943 & -0.35637\end{array}$

$\begin{array}{llll}\text { C } & -1.07095 & 2.56398 & -0.34541\end{array}$

$\begin{array}{llll}\mathrm{H} & 0.62718 & 3.88358 & -0.51076\end{array}$

$\begin{array}{llll}\mathrm{H} & -2.59293 & 1.02871 & -0.19787\end{array}$

$\begin{array}{llll}\mathrm{H} & -1.79138 & 3.37533 & -0.28890\end{array}$

$\begin{array}{llll}\mathrm{O} & 1.37780 & -1.70367 & -1.13584\end{array}$

$\begin{array}{llll}\mathrm{O} & -4.65328 & 0.80218 & 0.05679\end{array}$

$\begin{array}{llll}\text { C } & -4.81929 & -0.54029 & 0.28655\end{array}$

$\begin{array}{llll}\text { C } & -6.30695 & -0.89171 & 0.52227\end{array}$

$\begin{array}{llll}\text { C } & -4.32392 & -1.37679 & -0.91856\end{array}$

$\begin{array}{llll}\text { C } & -4.02291 & -0.99562 & 1.53466\end{array}$

$\begin{array}{llll}\mathrm{H} & -6.68252 & -0.32872 & 1.38539\end{array}$

$\begin{array}{llll}\mathrm{H} & -6.89410 & -0.59729 & -0.35615\end{array}$

$\begin{array}{llll}\mathrm{H} & -6.47163 & -1.96222 & 0.70755\end{array}$

$\begin{array}{llll}\mathrm{H} & -3.26540 & -1.15830 & -1.10670\end{array}$

$\begin{array}{llll}\mathrm{H} & -4.43264 & -2.45923 & -0.76507\end{array}$

$\begin{array}{llll}\mathrm{H} & -4.88899 & -1.09369 & -1.81492\end{array}$

$\begin{array}{llll}\mathrm{H} & -4.13618 & -2.06713 & 1.74922\end{array}$

$\begin{array}{llll}\mathrm{H} & -2.95657 & -0.78347 & 1.38792\end{array}$

$\begin{array}{llll}\mathrm{H} & -4.36193 & -0.42757 & 2.40960\end{array}$ 
Transition State for formation of $\mathbf{4 5}$ from $\mathbf{1 7}$ and

$\mathrm{OtBu}$ anion

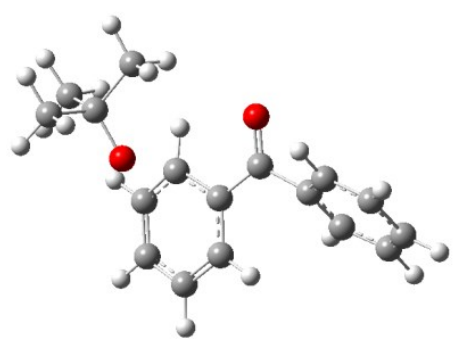

38

$-809.4594074$

$\begin{array}{lrrr}\mathrm{C} & -5.10676 & -0.68944 & 0.37800 \\ \mathrm{C} & -4.63181 & 0.47287 & -0.22909 \\ \mathrm{C} & -3.27433 & 0.60620 & -0.51979 \\ \mathrm{C} & -2.38391 & -0.43043 & -0.22151 \\ \mathrm{C} & -2.87105 & -1.60334 & 0.36448 \\ \mathrm{C} & -4.22292 & -1.72792 & 0.67640 \\ \mathrm{H} & -6.16204 & -0.78810 & 0.61365 \\ \mathrm{H} & -5.31740 & 1.27787 & -0.47566 \\ \mathrm{H} & -2.90698 & 1.51233 & -0.99330 \\ \mathrm{H} & -2.17865 & -2.41309 & 0.57628 \\ \mathrm{H} & -4.58870 & -2.63593 & 1.14617 \\ \mathrm{C} & -0.92247 & -0.36473 & -0.59182 \\ \mathrm{C} & -0.12721 & 0.80604 & -0.22909 \\ \mathrm{C} & -0.61645 & 1.83045 & 0.61240 \\ \mathrm{C} & 1.21147 & 0.87633 & -0.70544 \\ \mathrm{C} & 0.11949 & 2.97893 & 0.83758 \\ \mathrm{H} & -1.59007 & 1.72199 & 1.08120 \\ \mathrm{C} & 1.87747 & 2.13091 & -0.60911 \\ \mathrm{H} & 1.50402 & 0.16378 & -1.46708 \\ \mathrm{C} & 1.35775 & 3.13917 & 0.17336 \\ \mathrm{H} & -0.26605 & 3.76395 & 1.47997 \\ \mathrm{H} & 2.83408 & 2.26301 & -1.10580 \\ \mathrm{H} & 1.90255 & 4.07475 & 0.27689 \\ \mathrm{O} & -0.45147 & -1.32119 & -1.21422 \\ \mathrm{O} & 2.25590 & -0.23500 & 0.68946 \\ \mathrm{C} & 3.27430 & -1.06397 & 0.24335 \\ \mathrm{C} & 4.09660 & -1.54901 & 1.45419 \\ \mathrm{C} & 2.70977 & -2.30053 & -0.48538 \\ \mathrm{C} & 4.23711 & -0.32453 & -0.71331 \\ \mathrm{H} & 4.54504 & -0.69078 & 1.96782 \\ \mathrm{H} & 3.43727 & -2.06467 & 2.16129 \\ \mathrm{H} & 4.89978 & -2.23787 & 1.15997 \\ \mathrm{H} & 2.07524 & -1.98863 & -1.32082 \\ \mathrm{H} & 3.50411 & -2.95851 & -0.86174 \\ \mathrm{H} & 2.08025 & -2.87568 & 0.20412 \\ \mathrm{H} & 5.08348 & -0.95831 & -1.00675 \\ \mathrm{H} & 3.71812 & -0.01269 & -1.62712 \\ \mathrm{H} & 4.62820 & 0.57417 & -0.22244 \\ & & & \end{array}$


45<smiles>CCCCOC1C=CC=CC1=C([O-])c1ccccc1</smiles>

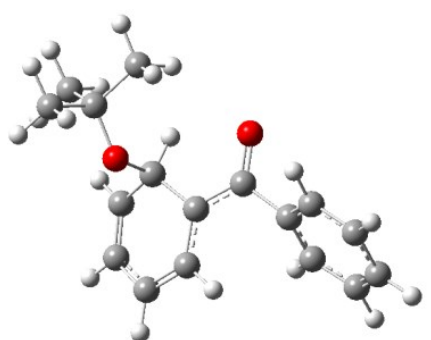

38

$-809.4797478$

$\begin{array}{lccc}\mathrm{C} & -5.12994 & -0.47372 & 0.29764 \\ \mathrm{C} & -4.55389 & 0.63735 & -0.31762 \\ \mathrm{C} & -3.17948 & 0.67168 & -0.55762 \\ \mathrm{C} & -2.36537 & -0.40805 & -0.19792 \\ \mathrm{C} & -2.95745 & -1.52718 & 0.39929 \\ \mathrm{C} & -4.32617 & -1.55756 & 0.65770 \\ \mathrm{H} & -6.19815 & -0.49805 & 0.49134 \\ \mathrm{H} & -5.17387 & 1.47917 & -0.61182 \\ \mathrm{H} & -2.73321 & 1.53784 & -1.03822 \\ \mathrm{H} & -2.33063 & -2.37550 & 0.65958 \\ \mathrm{H} & -4.76858 & -2.42711 & 1.13509 \\ \mathrm{C} & -0.88442 & -0.44785 & -0.50926 \\ \mathrm{C} & -0.05308 & 0.63349 & -0.12283 \\ \mathrm{C} & -0.50295 & 1.73619 & 0.65971 \\ \mathrm{C} & 1.39830 & 0.57215 & -0.49606 \\ \mathrm{C} & 0.24269 & 2.88106 & 0.79872 \\ \mathrm{H} & -1.47689 & 1.67738 & 1.14149 \\ \mathrm{C} & 1.96422 & 1.95531 & -0.66761 \\ \mathrm{H} & 1.50775 & -0.03059 & -1.40411 \\ \mathrm{C} & 1.45213 & 3.00441 & 0.02430 \\ \mathrm{H} & -0.11460 & 3.71477 & 1.39453 \\ \mathrm{H} & 2.84830 & 2.08534 & -1.28761 \\ \mathrm{H} & 1.93740 & 3.97758 & -0.04007 \\ \mathrm{O} & -0.47819 & -1.46891 & -1.12563 \\ \mathrm{O} & 2.13877 & -0.11883 & 0.57171 \\ \mathrm{C} & 3.19686 & -1.00635 & 0.20197 \\ \mathrm{C} & 3.91569 & -1.31213 & 1.51473 \\ \mathrm{C} & 2.62805 & -2.29912 & -0.39045 \\ \mathrm{C} & 4.18524 & -0.35931 & -0.77590 \\ \mathrm{H} & 4.33732 & -0.39481 & 1.93763 \\ \mathrm{H} & 3.21105 & -1.73590 & 2.23667 \\ \mathrm{H} & 4.72592 & -2.03086 & 1.35353 \\ \mathrm{H} & 2.01911 & -2.09661 & -1.27508 \\ \mathrm{H} & 3.43918 & -2.98411 & -0.66131 \\ \mathrm{H} & 1.98359 & -2.79061 & 0.34545 \\ \mathrm{H} & 5.02217 & -1.04169 & -0.95806 \\ \mathrm{H} & 3.71743 & -0.13960 & -1.74067 \\ \mathrm{H} & 4.57943 & 0.57305 & -0.35974\end{array}$


Reactant Complex for formation of $\mathbf{4 7}$ from $\mathbf{1 7}$ and

$\mathrm{O} t \mathrm{Bu}$ anion

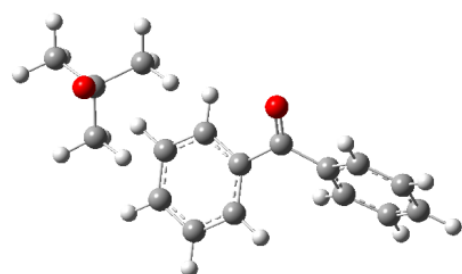

38

$-809.4818921$

\begin{tabular}{lccc}
$\mathrm{C}$ & -1.31648 & 1.76606 & -0.92637 \\
$\mathrm{C}$ & -0.03380 & 2.31452 & -0.89947 \\
$\mathrm{C}$ & 1.07756 & 1.48021 & -0.79390 \\
$\mathrm{C}$ & 0.90251 & 0.09195 & -0.73691 \\
$\mathrm{C}$ & -0.38965 & -0.44798 & -0.78282 \\
$\mathrm{C}$ & -1.50556 & 0.38170 & -0.86543 \\
$\mathrm{H}$ & -2.18186 & 2.41998 & -0.99649 \\
$\mathrm{H}$ & 0.10334 & 3.38983 & -0.95920 \\
$\mathrm{H}$ & 2.07665 & 1.90571 & -0.77991 \\
$\mathrm{H}$ & -0.50640 & -1.52750 & -0.74409 \\
$\mathrm{H}$ & -2.52188 & -0.03314 & -0.88081 \\
$\mathrm{C}$ & 2.06432 & -0.84605 & -0.69612 \\
$\mathrm{C}$ & 3.33468 & -0.43144 & -0.01781 \\
$\mathrm{C}$ & 3.33729 & 0.40958 & 1.10063 \\
$\mathrm{C}$ & 4.54132 & -0.96206 & -0.48896 \\
$\mathrm{C}$ & 4.53736 & 0.71449 & 1.74085 \\
$\mathrm{H}$ & 2.40226 & 0.80736 & 1.48330 \\
$\mathrm{C}$ & 5.74043 & -0.63909 & 0.13783 \\
$\mathrm{H}$ & 4.52346 & -1.62137 & -1.35119 \\
$\mathrm{C}$ & 5.73870 & 0.19825 & 1.25568 \\
$\mathrm{H}$ & 4.53369 & 1.35418 & 2.61743 \\
$\mathrm{H}$ & 6.67534 & -1.04031 & -0.24028 \\
$\mathrm{H}$ & 6.67335 & 0.44478 & 1.74993 \\
$\mathrm{O}$ & 1.98609 & -1.95243 & -1.21230 \\
$\mathrm{O}$ & -4.52486 & -0.58824 & -0.87041 \\
$\mathrm{C}$ & -4.97974 & -0.37810 & 0.40732 \\
$\mathrm{C}$ & -4.83469 & 1.10870 & 0.81535 \\
$\mathrm{C}$ & -6.47280 & -0.75910 & 0.54479 \\
$\mathrm{C}$ & -4.18087 & -1.22273 & 1.43026 \\
$\mathrm{H}$ & -3.77873 & 1.40068 & 0.76436 \\
$\mathrm{H}$ & -5.39521 & 1.73623 & 0.11157 \\
$\mathrm{H}$ & -5.20186 & 1.31198 & 1.83089 \\
$\mathrm{H}$ & -6.60596 & -1.81573 & 0.28234 \\
$\mathrm{H}$ & -6.86436 & -0.60142 & 1.55923 \\
$\mathrm{H}$ & -7.06879 & -0.15929 & -0.15382 \\
$\mathrm{H}$ & -4.51751 & -1.07363 & 2.46554 \\
$\mathrm{H}$ & -4.28124 & -2.28670 & 1.18351 \\
$\mathrm{H}$ & -3.11761 & -0.95969 & 1.36985 \\
& & & \\
\hline
\end{tabular}


Transition State for formation of $\mathbf{4 7}$ from 17 and $\mathrm{O} t \mathrm{Bu}$ anion

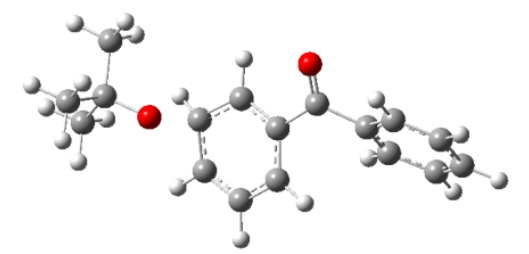

38

$-809.4503761$

$\mathrm{C}$

$\quad 1.57376$

$\begin{array}{ll}\mathrm{C} & 0.40222\end{array}$

C $\quad-0.64972$

C $\quad-0.50268$

$\begin{array}{ll}\text { C } & 0.67574\end{array}$

C $\quad 1.82982$

$\begin{array}{ll}\mathrm{C} & 1.82982 \\ \mathrm{H} & 2.35085\end{array}$

$\mathrm{H} \quad 0.28245$

$-1.55871$

0.73568

2.57021

$-1.60210$

$-3.03157$

$-3.49191$

$-3.93695$

$-4.84213$

$-2.79483$

$-5.28012$

$-3.57127$

$-5.73480$

$-5.19637$

$-5.97391$

$-6.78396$

$-1.37855$

2.91253

4.24769

4.96905

4.95597

4.36537

4.52435

4.88542

6.03252

4.46147

6.01264

4.89895

5.41299

3.86496

3.88901
1.97195

2.22196

1.29731

0.11478

$-0.15339$

0.68288

2.73146

3.17521

1.50100

$-1.05433$

0.63363

$-0.88418$

$-0.44581$

0.78414

$-1.33773$

1.11643

1.47165

$-0.99618$

$-2.29560$

0.23233

2.06625

$-1.68663$

0.49705

$-2.07221$

$-0.20338$

$-0.41629$

0.91068

$-1.07608$

$-1.36281$

1.41057

1.58632

0.74779

$-2.02167$

$-1.28021$

$-0.42013$

$-1.57285$

$-2.31068$

$-0.93407$
$-0.10672$

0.59235

0.61613

$-0.13691$

$-0.83020$

$-0.68696$

$-0.15013$

1.10364

1.17075

$-1.43445$

$-1.47984$

$-0.22392$

$-0.06128$

$-0.54450$

0.52514

$-0.43828$

$-1.01312$

0.65143

0.88239

0.16699

$-0.82651$

1.12096

0.25764

$-0.43576$

0.52699

0.17342

$-0.14138$

1.36721

$-1.03875$

$-1.00867$

0.71744

$-0.35500$

1.61427

1.15112

2.24250

$-1.28705$

$-0.81152$

$-1.92689$ 
<smiles>CCCCOC1C=CC=C(C(=O)c2ccccc2)[CH-]1</smiles>

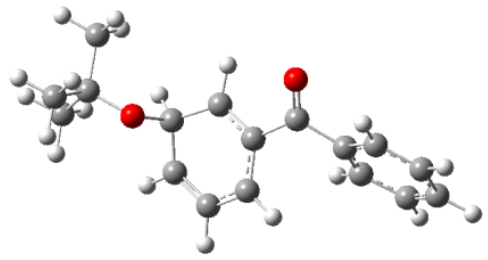

38

$-809.4555653$

$\begin{array}{lrrr}\mathrm{C} & 1.61390 & 1.90790 & -0.10802 \\ \mathrm{C} & 0.45450 & 2.16663 & 0.59449 \\ \mathrm{C} & -0.59546 & 1.23259 & 0.69188 \\ \mathrm{C} & -0.45718 & 0.03794 & -0.05718 \\ \mathrm{C} & 0.70163 & -0.25512 & -0.75955 \\ \mathrm{C} & 1.94230 & 0.53414 & -0.57169 \\ \mathrm{H} & 2.36441 & 2.68717 & -0.22758 \\ \mathrm{H} & 0.32333 & 3.15108 & 1.04453 \\ \mathrm{H} & -1.50052 & 1.45464 & 1.24452 \\ \mathrm{H} & 0.73321 & -1.14513 & -1.38372 \\ \mathrm{H} & 2.54842 & 0.54320 & -1.48351 \\ \mathrm{C} & -1.58237 & -0.93088 & -0.14808 \\ \mathrm{C} & -3.00188 & -0.44084 & -0.04375 \\ \mathrm{C} & -3.39821 & 0.79133 & -0.57520 \\ \mathrm{C} & -3.96148 & -1.28320 & 0.52927 \\ \mathrm{C} & -4.73861 & 1.17447 & -0.52987 \\ \mathrm{H} & -2.65650 & 1.43992 & -1.03008 \\ \mathrm{C} & -5.29534 & -0.89061 & 0.59581 \\ \mathrm{H} & -3.64474 & -2.24464 & 0.92243 \\ \mathrm{C} & -5.68574 & 0.33996 & 0.06285 \\ \mathrm{H} & -5.04307 & 2.12580 & -0.95540 \\ \mathrm{H} & -6.03097 & -1.54317 & 1.05596 \\ \mathrm{H} & -6.72709 & 0.64491 & 0.10583 \\ \mathrm{O} & -1.39886 & -2.13293 & -0.32434 \\ \mathrm{O} & 2.81151 & -0.16256 & 0.44710 \\ \mathrm{C} & 4.18080 & -0.37290 & 0.11834 \\ \mathrm{C} & 4.89188 & 0.94380 & -0.22498 \\ \mathrm{C} & 4.80495 & -0.96647 & 1.38065 \\ \mathrm{C} & 4.32103 & -1.37697 & -1.03469 \\ \mathrm{H} & 4.49315 & 1.39636 & -1.13818 \\ \mathrm{H} & 4.76796 & 1.65937 & 0.59420 \\ \mathrm{H} & 5.96237 & 0.76698 & -0.37765 \\ \mathrm{H} & 4.29258 & -1.89510 & 1.65049 \\ \mathrm{H} & 5.86717 & -1.18406 & 1.22497 \\ \mathrm{H} & 4.70838 & -0.26266 & 2.21318 \\ \mathrm{H} & 5.37707 & -1.59675 & -1.22694 \\ \mathrm{H} & 3.81114 & -2.31028 & -0.77467 \\ \mathrm{H} & 3.88414 & -0.99446 & -1.96206 \\ & & & \\ & & & \end{array}$


Reactant Complex for formation of $\mathbf{2 0}$ from $\mathbf{1 7}$ and

$\mathrm{O} t \mathrm{Bu}$ anion

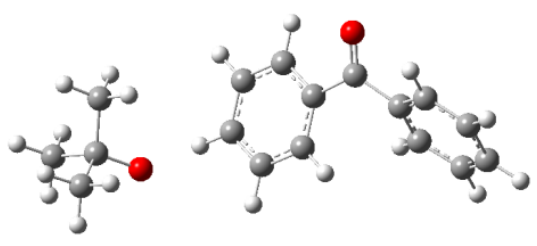

38

$-809.4824518$

$\begin{array}{lrrc}\mathrm{C} & 5.90193 & -1.42010 & 0.02160 \\ \mathrm{C} & 4.79318 & -1.73406 & -0.76399 \\ \mathrm{C} & 3.66907 & -0.90974 & -0.74735 \\ \mathrm{C} & 3.65923 & 0.24456 & 0.04389 \\ \mathrm{C} & 4.78326 & 0.56600 & 0.81397 \\ \mathrm{C} & 5.89572 & -0.26930 & 0.81297 \\ \mathrm{H} & 6.77226 & -2.06887 & 0.01567 \\ \mathrm{H} & 4.80152 & -2.62126 & -1.38880 \\ \mathrm{H} & 2.80972 & -1.15419 & -1.36418 \\ \mathrm{H} & 4.76749 & 1.47110 & 1.41317 \\ \mathrm{H} & 6.75856 & -0.02337 & 1.42362 \\ \mathrm{C} & 2.50307 & 1.19815 & 0.04776 \\ \mathrm{C} & 1.11253 & 0.68398 & -0.12574 \\ \mathrm{C} & 0.73332 & -0.59745 & 0.29423 \\ \mathrm{C} & 0.14899 & 1.54451 & -0.66902 \\ \mathrm{C} & -0.59270 & -1.00795 & 0.16686 \\ \mathrm{H} & 1.46582 & -1.26323 & 0.74098 \\ \mathrm{C} & -1.16774 & 1.12001 & -0.80902 \\ \mathrm{H} & 0.45199 & 2.53944 & -0.98113 \\ \mathrm{C} & -1.55131 & -0.15970 & -0.39218 \\ \mathrm{H} & -0.88248 & -1.99785 & 0.50725 \\ \mathrm{H} & -1.90793 & 1.78775 & -1.24142 \\ \mathrm{O} & 2.70894 & 2.39553 & 0.19672 \\ \mathrm{H} & -2.59566 & -0.48531 & -0.49750 \\ \mathrm{O} & -4.54872 & -1.03841 & -0.73092 \\ \mathrm{C} & -5.37456 & -0.33290 & 0.10741 \\ \mathrm{C} & -6.84924 & -0.41518 & -0.35246 \\ \mathrm{C} & -5.29875 & -0.87962 & 1.55316 \\ \mathrm{C} & -4.97885 & 1.16412 & 0.15015 \\ \mathrm{H} & -6.93694 & -0.01654 & -1.37043 \\ \mathrm{H} & -7.16895 & -1.46412 & -0.37135 \\ \mathrm{H} & -7.53362 & 0.14473 & 0.29990 \\ \mathrm{H} & -4.26500 & -0.81113 & 1.91369 \\ \mathrm{H} & -5.94771 & -0.33615 & 2.25379 \\ \mathrm{H} & -5.59002 & -1.93705 & 1.55871 \\ \mathrm{H} & -5.63203 & 1.76183 & 0.80071 \\ \mathrm{H} & -3.94814 & 1.26411 & 0.51111 \\ \mathrm{H} & -5.02358 & 1.58126 & -0.86369 \\ & & & \\ & & & \end{array}$


Transition State for formation of $\mathbf{2 0}$ from $\mathbf{1 7}$ and

$\mathrm{O} t \mathrm{Bu}$ anion

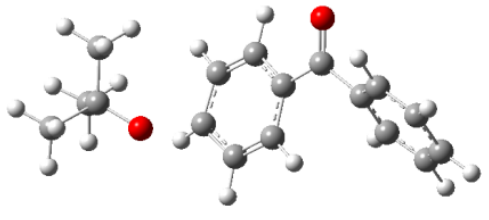

38

$-809.4600997$

$\begin{array}{lrrr}\mathrm{C} & 5.54083 & -0.87473 & 0.67246 \\ \mathrm{C} & 4.70913 & -1.43198 & -0.29855 \\ \mathrm{C} & 3.49667 & -0.82040 & -0.61415 \\ \mathrm{C} & 3.11460 & 0.36270 & 0.02706 \\ \mathrm{C} & 3.96482 & 0.92910 & 0.98288 \\ \mathrm{C} & 5.16588 & 0.30683 & 1.31482 \\ \mathrm{H} & 6.48066 & -1.35642 & 0.92465 \\ \mathrm{H} & 5.00346 & -2.34258 & -0.81114 \\ \mathrm{H} & 2.85111 & -1.25270 & -1.37314 \\ \mathrm{H} & 3.67065 & 1.85855 & 1.46169 \\ \mathrm{H} & 5.81284 & 0.74436 & 2.06903 \\ \mathrm{C} & 1.85371 & 1.09626 & -0.35089 \\ \mathrm{C} & 0.62102 & 0.34939 & -0.58157 \\ \mathrm{C} & 0.41122 & -0.96918 & -0.11147 \\ \mathrm{C} & -0.42354 & 0.95545 & -1.31889 \\ \mathrm{C} & -0.78423 & -1.62289 & -0.31925 \\ \mathrm{H} & 1.20499 & -1.47992 & 0.42688 \\ \mathrm{C} & -1.61291 & 0.30095 & -1.54958 \\ \mathrm{H} & -0.24791 & 1.94090 & -1.74326 \\ \mathrm{C} & -1.88447 & -0.95768 & -0.93565 \\ \mathrm{H} & -0.91840 & -2.63474 & 0.05073 \\ \mathrm{H} & -2.37668 & 0.77053 & -2.16339 \\ \mathrm{O} & 1.91654 & 2.32615 & -0.46613 \\ \mathrm{H} & -2.70292 & -1.55677 & -1.31458 \\ \mathrm{O} & -3.02614 & -0.64814 & 0.70359 \\ \mathrm{C} & -4.26385 & -0.02389 & 0.59785 \\ \mathrm{C} & -5.12218 & -0.41166 & 1.81777 \\ \mathrm{C} & -4.11003 & 1.51117 & 0.58044 \\ \mathrm{C} & -5.02550 & -0.45663 & -0.67361 \\ \mathrm{H} & -5.26698 & -1.49780 & 1.83918 \\ \mathrm{H} & -4.60656 & -0.11668 & 2.73845 \\ \mathrm{H} & -6.10752 & 0.07279 & 1.79911 \\ \mathrm{H} & -3.50731 & 1.81781 & -0.28012 \\ \mathrm{H} & -5.07922 & 2.02472 & 0.53059 \\ \mathrm{H} & -3.59067 & 1.83540 & 1.48975 \\ \mathrm{H} & -6.03563 & -0.03003 & -0.69919 \\ \mathrm{H} & -4.50195 & -0.12898 & -1.57884 \\ \mathrm{H} & -5.11221 & -1.54942 & -0.70414 \\ & & & \end{array}$


<smiles>CCCCOC1C=CC(=C([O-])c2ccccc2)C=C1</smiles>

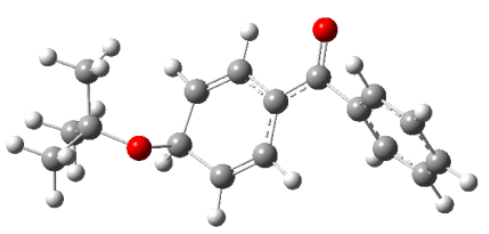

38

$-809.4795644$

\begin{tabular}{lrrr}
$\mathrm{C}$ & 5.43204 & -1.12117 & 0.51928 \\
$\mathrm{C}$ & 4.72102 & -1.30372 & -0.66650 \\
$\mathrm{C}$ & 3.54569 & -0.58682 & -0.89767 \\
$\mathrm{C}$ & 3.07364 & 0.32988 & 0.04798 \\
$\mathrm{C}$ & 3.80682 & 0.52124 & 1.22452 \\
$\mathrm{C}$ & 4.97006 & -0.20569 & 1.46723 \\
$\mathrm{H}$ & 6.34284 & -1.68347 & 0.70223 \\
$\mathrm{H}$ & 5.08192 & -2.00419 & -1.41407 \\
$\mathrm{H}$ & 2.99547 & -0.72991 & -1.82409 \\
$\mathrm{H}$ & 3.45228 & 1.24944 & 1.94865 \\
$\mathrm{H}$ & 5.51918 & -0.05602 & 2.39232 \\
$\mathrm{C}$ & 1.85189 & 1.19115 & -0.18644 \\
$\mathrm{C}$ & 0.61265 & 0.58761 & -0.51060 \\
$\mathrm{C}$ & 0.36875 & -0.83273 & -0.54524 \\
$\mathrm{C}$ & -0.50916 & 1.41761 & -0.86879 \\
$\mathrm{C}$ & -0.85493 & -1.36055 & -0.79822 \\
$\mathrm{H}$ & 1.19955 & -1.51501 & -0.37942 \\
$\mathrm{C}$ & -1.74431 & 0.92285 & -1.12673 \\
$\mathrm{H}$ & -0.32092 & 2.48341 & -0.98296 \\
$\mathrm{C}$ & -2.09349 & -0.52104 & -0.90262 \\
$\mathrm{H}$ & -0.98624 & -2.43947 & -0.83873 \\
$\mathrm{H}$ & -2.52909 & 1.59199 & -1.47339 \\
$\mathrm{O}$ & 2.02509 & 2.43361 & -0.05019 \\
$\mathrm{H}$ & -2.74414 & -0.89353 & -1.70586 \\
$\mathrm{O}$ & -2.82505 & -0.76348 & 0.34530 \\
$\mathrm{C}$ & -4.14885 & -0.24466 & 0.52930 \\
$\mathrm{C}$ & -4.79432 & -1.20422 & 1.53041 \\
$\mathrm{C}$ & -4.09057 & 1.15913 & 1.14439 \\
$\mathrm{C}$ & -4.97243 & -0.22886 & -0.76125 \\
$\mathrm{H}$ & -4.86294 & -2.20881 & 1.10176 \\
$\mathrm{H}$ & -4.18798 & -1.25561 & 2.44001 \\
$\mathrm{H}$ & -5.80003 & -0.86611 & 1.80037 \\
$\mathrm{H}$ & -3.66558 & 1.88407 & 0.44734 \\
$\mathrm{H}$ & -5.09577 & 1.49311 & 1.42530 \\
$\mathrm{H}$ & -3.46622 & 1.14060 & 2.04316 \\
$\mathrm{H}$ & -5.99919 & 0.06868 & -0.52567 \\
$\mathrm{H}$ & -4.57909 & 0.48289 & -1.49330 \\
$\mathrm{H}$ & -5.00134 & -1.22320 & -1.21880 \\
& & & \\
\hline
\end{tabular}


Reactant Complex for formation of 46 from 45 and

$\mathrm{O} t \mathrm{Bu}$ anion

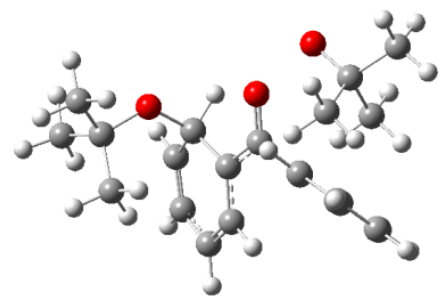

52

$-1042.5207433$

\begin{tabular}{|c|c|c|c|}
\hline & 1.07281 & 5.10002 & 0.36101 \\
\hline & 1.68861 & 3.98540 & 0.93030 \\
\hline C & 1.23665 & 2.70132 & 0.62325 \\
\hline & 0.17238 & 2.51272 & -0.26521 \\
\hline $\mathrm{C}$ & -0.42299 & 3.63716 & -0.84853 \\
\hline & 0.01229 & 4.92224 & -0.52979 \\
\hline 11 & 1.41922 & 6.09989 & 0.60542 \\
\hline $\mathrm{H}$ & 2.52172 & 4.11439 & 1.61530 \\
\hline $\mathrm{H}$ & 1.71598 & 1.83406 & 1.06937 \\
\hline & -1.23300 & 3.49181 & -1.55827 \\
\hline $\mathrm{H}$ & -0.47041 & 5.78514 & -0.97972 \\
\hline C & -0.29778 & 1.13567 & -0.68885 \\
\hline & -0.68291 & 0.18653 & 0.28928 \\
\hline C & -0.71291 & 0.49054 & 1.67968 \\
\hline C & -0.99605 & -1.20924 & -0.19207 \\
\hline C & -0.85428 & -0.47171 & 2.64813 \\
\hline$H$ & -0.61717 & 1.53019 & 1.98694 \\
\hline $\mathrm{C}$ & -0.95642 & -2.20762 & 0.92822 \\
\hline $\mathrm{H}$ & -0.25661 & -1.48103 & -0.95873 \\
\hline g & -0.92092 & -1.85193 & 2.23437 \\
\hline H & -0.86948 & -0.21203 & 3.70175 \\
\hline $\mathrm{H}$ & -0.96816 & -3.25983 & 0.64851 \\
\hline $\mathrm{H}$ & -0.91888 & -2.63041 & 2.99682 \\
\hline $\mathrm{O}$ & -0.30219 & 0.92201 & -1.93067 \\
\hline $\mathrm{O}$ & -2.20986 & -1.33190 & -1.01793 \\
\hline $\mathrm{C}$ & -3.53968 & -1.30445 & -0.49775 \\
\hline $\mathrm{C}$ & -4.39441 & -0.94070 & -1.71511 \\
\hline $\mathrm{C}$ & -3.96176 & -2.69222 & 0.00739 \\
\hline $\mathrm{C}$ & -3.75453 & $\begin{array}{l}-0.25994 \\
\end{array}$ & 0.59827 \\
\hline $\mathrm{H}$ & -4.10082 & 0.04189 & -2.09758 \\
\hline $\mathrm{H}$ & -4.25112 & -1.67882 & -2.51083 \\
\hline $\mathrm{H}$ & -5.45678 & -0.91492 & -1.44955 \\
\hline $\mathrm{H}$ & -3.43306 & -2.95731 & 0.92527 \\
\hline $\mathrm{H}$ & -5.03948 & -2.71068 & 0.20812 \\
\hline $\mathrm{H}$ & -3.73806 & -3.44585 & -0.75525 \\
\hline $\mathrm{H}$ & -4.81339 & -0.25578 & 0.88240 \\
\hline $\mathrm{H}$ & -3.15692 & -0.47942 & 1.48609 \\
\hline $\mathrm{H}$ & -3.48241 & 0.73740 & 0.23934 \\
\hline $\mathrm{O}$ & 3.40051 & -3.28512 & -0.99105 \\
\hline $\mathrm{C}$ & 3.88156 & -2.12610 & -0.43806 \\
\hline C & 2.73857 & -1.14255 & -0.09320 \\
\hline $\mathrm{C}$ & 4.66464 & -2.41500 & 0.86680 \\
\hline 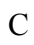 & 4.84563 & -1.40351 & -1.41089 \\
\hline $\mathrm{H}$ & 2.17864 & -0.88050 & -1.00003 \\
\hline 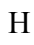 & 2.03181 & -1.61457 & 0.60078 \\
\hline H & 3.10172 & -0.21112 & 0.36481 \\
\hline 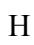 & 5.49227 & -3.10173 & 0.64867 \\
\hline & 5.07740 & -1.50881 & 1.33184 \\
\hline$H$ & 4.00039 & -2.90402 & 1.58978 \\
\hline & 5.25244 & -0.46897 & -0.999 \\
\hline & 5.68289 & -2.06836 & \\
\hline & & -1.17017 & -2.34 \\
\hline
\end{tabular}


Transition State for formation of $\mathbf{4 6}$ from 45 and

$\mathrm{O} t \mathrm{Bu}$ anion

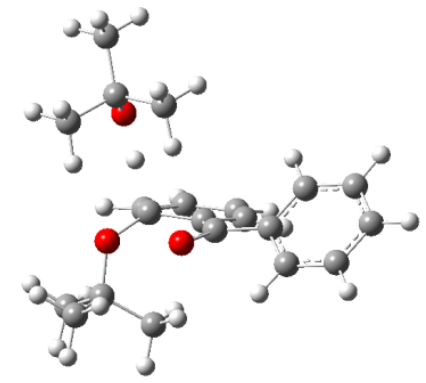

52

$-1042.4790474$

\begin{tabular}{|c|c|c|c|}
\hline & -5.37397 & 0.13865 & -0.18284 \\
\hline & -4.54667 & 0.80351 & 0.72458 \\
\hline & -3.16229 & 0.64500 & 0.66699 \\
\hline & -2.55514 & -0.18413 & -0.29411 \\
\hline & -3.40535 & -0.81563 & -1.2202 \\
\hline & -4.78969 & -0.67198 & -1.16019 \\
\hline & -6.45229 & 0.26163 & -0.13906 \\
\hline & -4.98015 & 1.46138 & 1.47380 \\
\hline & -2.53238 & 1.18868 & 1.36620 \\
\hline & -2.94952 & -1.42352 & -1.996 \\
\hline & -5.41783 & -1.19014 & -1.88081 \\
\hline & -1.06324 & -0.32483 & -0.46547 \\
\hline & -0.23878 & -0.46391 & 0.65471 \\
\hline & -0.79431 & -0.76309 & 1.96065 \\
\hline & 1.28272 & -0.35874 & 0.60340 \\
\hline & -0.05937 & -0.94428 & 3.09580 \\
\hline & -1.86645 & -0.93080 & 2.03297 \\
\hline & 1.98694 & -0.70780 & 1.83577 \\
\hline & 1.59283 & 1.03005 & 0.58765 \\
\hline & 1.39234 & -0.88904 & 3.04372 \\
\hline & -0.55935 & -1.20275 & 4.02686 \\
\hline & 3.07599 & -0.71482 & 1.76298 \\
\hline & 1.98059 & -1.01851 & 3.94955 \\
\hline & -0.66675 & -0.33243 & -1.70247 \\
\hline & 1.96121 & -0.84414 & -0.56368 \\
\hline & 2.05422 & -2.24805 & -0.84641 \\
\hline & 2.13176 & -2.31453 & -2.37125 \\
\hline & 3.33795 & -2.82143 & -0.23075 \\
\hline & 0.84841 & -3.05714 & -0.36653 \\
\hline & 1.21788 & -1.87238 & -2.77949 \\
\hline & 2.99499 & -1.74124 & -2.72850 \\
\hline & 2.23187 & -3.34909 & -2.71925 \\
\hline & 3.27342 & -2.83860 & 0.86106 \\
\hline & 3.50743 & -3.84692 & -0.58110 \\
\hline & 4.19916 & -2.20883 & -0.51947 \\
\hline & 0.99612 & -4.10928 & -0.63972 \\
\hline & 0.73334 & -2.98957 & 0.72024 \\
\hline & -0.06238 & -2.67916 & -0.83822 \\
\hline & 1.93276 & 2.20597 & 0.74563 \\
\hline & 1.63442 & 3.04320 & -0.33396 \\
\hline & 0.13173 & 2.98967 & -0.65760 \\
\hline & 2.01345 & 4.48271 & 0.04252 \\
\hline & 2.44658 & 2.62211 & -1.57193 \\
\hline & -0.16843 & 1.96337 & -0.89485 \\
\hline & -0.43952 & 3.31822 & 0.22011 \\
\hline & -0.12636 & 3.64276 & -1.50156 \\
\hline & 3.08126 & 4.53961 & 0.28285 \\
\hline & 1.80312 & 5.18473 & -0.77485 \\
\hline & 1.44594 & 4.79723 & 0.92570 \\
\hline & 2.20323 & 3.23144 & -2.45163 \\
\hline & 3.51 & 2.72971 & -1.361 \\
\hline & & 1.56989 & \\
\hline
\end{tabular}


Product Complex of 46 and $\mathrm{HO}^{t} \mathrm{Bu}$

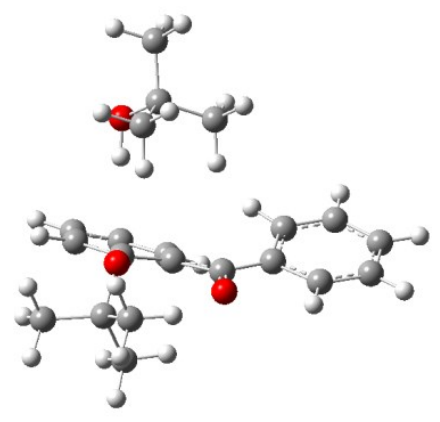


46<smiles>CCCCO[C]1C=CC=CC1=C([O-])c1ccccc1</smiles>

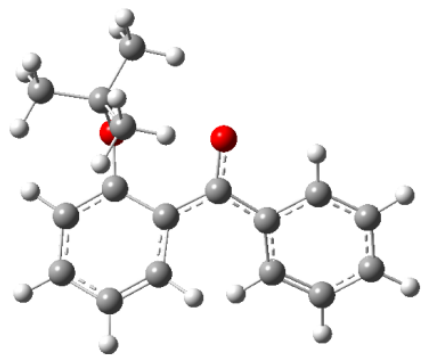

37

$-808.9107073$

\begin{tabular}{lrrr}
$\mathrm{C}$ & -5.09273 & -0.40979 & -0.11715 \\
$\mathrm{C}$ & -4.36586 & 0.77381 & -0.36630 \\
$\mathrm{C}$ & -2.98319 & 0.81716 & -0.30598 \\
$\mathrm{C}$ & -2.18053 & -0.34127 & 0.01404 \\
$\mathrm{C}$ & -2.95579 & -1.54818 & 0.19609 \\
$\mathrm{C}$ & -4.34177 & -1.56767 & 0.14772 \\
$\mathrm{H}$ & -6.17765 & -0.42811 & -0.15316 \\
$\mathrm{H}$ & -4.90106 & 1.68619 & -0.62911 \\
$\mathrm{H}$ & -2.49893 & 1.75416 & -0.55951 \\
$\mathrm{H}$ & -2.40064 & -2.46135 & 0.38060 \\
$\mathrm{H}$ & -4.85764 & -2.51342 & 0.31667 \\
$\mathrm{C}$ & -0.74659 & -0.46026 & 0.03630 \\
$\mathrm{C}$ & 0.09885 & 0.71198 & 0.02797 \\
$\mathrm{C}$ & -0.33415 & 1.98764 & 0.54559 \\
$\mathrm{C}$ & 1.47571 & 0.74059 & -0.42306 \\
$\mathrm{C}$ & 0.41382 & 3.15243 & 0.48422 \\
$\mathrm{H}$ & -1.29254 & 2.02962 & 1.05221 \\
$\mathrm{C}$ & 2.20425 & 1.91917 & -0.50513 \\
$\mathrm{C}$ & 1.69919 & 3.15968 & -0.07928 \\
$\mathrm{H}$ & -0.00436 & 4.06722 & 0.90265 \\
$\mathrm{H}$ & 3.20258 & 1.85078 & -0.93248 \\
$\mathrm{H}$ & 2.28966 & 4.06697 & -0.15735 \\
$\mathrm{O}$ & -0.22876 & -1.69128 & 0.06450 \\
$\mathrm{O}$ & 2.09847 & -0.40260 & -0.90163 \\
$\mathrm{C}$ & 2.91605 & -1.17213 & 0.01309 \\
$\mathrm{C}$ & 2.79152 & -2.60737 & -0.48613 \\
$\mathrm{C}$ & 4.36247 & -0.68120 & -0.09312 \\
$\mathrm{C}$ & 2.42404 & -1.07492 & 1.45548 \\
$\mathrm{H}$ & 1.74084 & -2.89765 & -0.40297 \\
$\mathrm{H}$ & 3.10504 & -2.66740 & -1.53479 \\
$\mathrm{H}$ & 3.42389 & -3.28037 & 0.10349 \\
$\mathrm{H}$ & 4.44950 & 0.34781 & 0.26968 \\
$\mathrm{H}$ & 5.02376 & -1.31293 & 0.51069 \\
$\mathrm{H}$ & 4.70099 & -0.71585 & -1.13444 \\
$\mathrm{H}$ & 3.02221 & -1.74771 & 2.08072 \\
$\mathrm{H}$ & 2.53560 & -0.05638 & 1.84266 \\
$\mathrm{H}$ & 1.36937 & -1.36845 & 1.47553 \\
& & & \\
\hline
\end{tabular}


Single Point Radical Anion using Optimised Geometry

\section{6}

37

$-808.8706291$

C $\quad-5.09273100 \quad-0.40979100 \quad-0.11715000$

$\begin{array}{llll}\text { C } & -4.36585900 & 0.77381000 & -0.36630500\end{array}$

$\begin{array}{lllll}\text { C } & & -2.98319200 & 0.81716000 & -0.30597700\end{array}$

$\begin{array}{llll}\text { C } & -2.18053100 & -0.34126600 & 0.01404400\end{array}$

$\begin{array}{llll}\text { C } & -2.95578500 & -1.54817800 & 0.19608700\end{array}$

$\begin{array}{llll}\mathrm{C} & -4.34176800 & -1.56767000 & 0.14771600\end{array}$

$\mathrm{H} \quad-6.17765200 \quad-0.42811000 \quad-0.15316300$

$\mathrm{H} \quad-4.90106100 \quad 1.68619100 \quad-0.62911300$

$\mathrm{H} \quad-2.49893200 \quad 1.75416200 \quad-0.55951500$

$\mathrm{H} \quad-2.40064000 \quad-2.46134800 \quad 0.38059500$

$\mathrm{H} \quad-4.85764100 \quad-2.51342200 \quad 0.31667100$

$\begin{array}{llll}\text { C } & -0.74659400 & -0.46026300 & 0.03629600\end{array}$

$\begin{array}{lllll}\mathrm{C} & 0.09885300 & 0.71197600 & 0.02796500\end{array}$

$\begin{array}{lllll}\text { C } & -0.33415200 & 1.98763800 & 0.54559200\end{array}$

$\begin{array}{lllll}\text { C } & 1.47570900 & 0.74058600 & -0.42306000\end{array}$

$\begin{array}{llll}\text { C } & 0.41382500 & 3.15243300 & 0.48421600\end{array}$

$\begin{array}{llll}\mathrm{H} & -1.29254200 & 2.02962200 & 1.05221200\end{array}$

$\begin{array}{llll}\mathrm{C} & 2.20424600 & 1.91916700 & -0.50513000\end{array}$

C $\quad 1.69918900 \quad 3.15967600 \quad-0.07928100$

$\mathrm{H} \quad-\quad-0.00436100 \quad 4.06722000 \quad 0.90265500$

$\mathrm{H} \quad 3.20258300 \quad 1.85078400 \quad-0.93248100$

$\begin{array}{lllll}\mathrm{H} & 2.28966200 & 4.06696900 & -0.15735400\end{array}$

$\begin{array}{lllll}\mathrm{O} & -0.22875800 & -1.69128000 & 0.06449700\end{array}$

$\begin{array}{llll}\text { O } & 2.09846900 & -0.40259600 & -0.90163000\end{array}$

$\begin{array}{llll}\text { C } & 2.91604600 & -1.17213500 & 0.01308800\end{array}$

$\begin{array}{llll}\text { C } & 2.79151900 & -2.60737400 & -0.48612900\end{array}$

$\begin{array}{llll}\text { C } & 4.36246900 & -0.68119800 & -0.09312000\end{array}$

$\begin{array}{llll}\mathrm{C} & 2.42403600 & -1.07492500 & 1.45548100\end{array}$

$\mathrm{H} \quad \begin{array}{llll}\mathrm{H} & 1.74084000 & -2.89764900 & -0.40297300\end{array}$

$\mathrm{H} \quad 3.10504100 \quad-2.66739600 \quad-1.53479200$

$\mathrm{H} \quad 3.42389100 \quad-3.28037300 \quad 0.10348900$

$\mathrm{H} \quad 4.44950100 \quad 0.34781400 \quad 0.26967800$

$\mathrm{H} \quad \begin{array}{llll}\mathrm{H} & 5.02376100 & -1.31293000 & 0.51069300\end{array}$

$\mathrm{H} \quad 4.70099300 \quad-0.71584700 \quad-1.13444500$

$\begin{array}{llll}\mathrm{H} & 3.02220900 & -1.74771000 & 2.08072100\end{array}$

$\begin{array}{llll}\mathrm{H} & 2.53560000 & -0.05637700 & 1.84266200\end{array}$

$\mathrm{H} \quad 1.36937300 \quad-1.36845300 \quad 1.47553300$ 


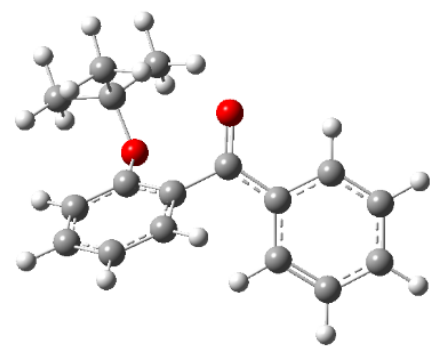

37

$-808.8808189$

$\begin{array}{lrrr}\mathrm{C} & -4.87949000 & -0.42050500 & -0.63585500 \\ \mathrm{C} & -4.04384100 & 0.63688300 & -1.03822500 \\ \mathrm{C} & -2.71673200 & 0.69602200 & -0.64534400 \\ \mathrm{C} & -2.13944000 & -0.31170400 & 0.18834400 \\ \mathrm{C} & -3.00330300 & -1.38500700 & 0.57242400 \\ \mathrm{C} & -4.32935800 & -1.42858500 & 0.17128400 \\ \mathrm{H} & -5.91823900 & -0.45902000 & -0.94804000 \\ \mathrm{H} & -4.44040300 & 1.42271500 & -1.67747200 \\ \mathrm{H} & -2.09965400 & 1.51890000 & -0.99476400 \\ \mathrm{H} & -2.58828100 & -2.17165800 & 1.19452000 \\ \mathrm{H} & -4.95281800 & -2.26164500 & 0.48971600 \\ \mathrm{C} & -0.76400200 & -0.33218600 & 0.61315400 \\ \mathrm{C} & 0.11345500 & 0.84941900 & 0.33623000 \\ \mathrm{C} & -0.25291600 & 2.13361900 & 0.77352600 \\ \mathrm{C} & 1.35792900 & 0.71827200 & -0.31305500 \\ \mathrm{C} & 0.56972200 & 3.24199600 & 0.59024400 \\ \mathrm{H} & -1.20829900 & 2.25054400 & 1.27979900 \\ \mathrm{C} & 2.17770200 & 1.83077300 & -0.51814600 \\ \mathrm{C} & 1.79583700 & 3.09073600 & -0.05944500 \\ \mathrm{H} & 0.25641300 & 4.21671500 & 0.95243900 \\ \mathrm{H} & 3.11088200 & 1.70057200 & -1.05765800 \\ \mathrm{H} & 2.44568700 & 3.94567100 & -0.22073000 \\ \mathrm{O} & -0.26809100 & -1.32522900 & 1.25366100 \\ \mathrm{O} & 1.70715200 & -0.49604100 & -0.84827500 \\ \mathrm{C} & 2.75596700 & -1.29979000 & -0.23306200 \\ \mathrm{C} & 2.25650900 & -2.73285900 & -0.38164200 \\ \mathrm{C} & 4.04916500 & -1.09201300 & -1.02039700 \\ \mathrm{C} & 2.94716600 & -0.95676600 & 1.24069700 \\ \mathrm{H} & 1.32098100 & -2.83808100 & 0.17436900 \\ \mathrm{H} & 2.07483600 & -2.95816000 & -1.43767600 \\ \mathrm{H} & 2.99908800 & -3.43952800 & 0.00230600 \\ \mathrm{H} & 4.43118800 & -0.07468600 & -0.89482200 \\ \mathrm{H} & 4.81834000 & -1.78716100 & -0.66788300 \\ \mathrm{H} & 3.87657200 & -1.27432000 & -2.08555700 \\ \mathrm{H} & 3.65718100 & -1.66631100 & 1.67713600 \\ \mathrm{H} & 3.35217800 & 0.05142700 & 1.37168300 \\ \mathrm{H} & 1.98563000 & -1.03564500 & 1.75515300\end{array}$


Single Point Dianion using

Optimised Geometry 49

37

$-808.9011778$

$\begin{array}{lrrr}\mathrm{C} & -4.87949000 & -0.42050500 & -0.63585500 \\ \mathrm{C} & -4.04384100 & 0.63688300 & -1.03822500 \\ \mathrm{C} & -2.71673200 & 0.69602200 & -0.64534400 \\ \mathrm{C} & -2.13944000 & -0.31170400 & 0.18834400 \\ \mathrm{C} & -3.00330300 & -1.38500700 & 0.57242400 \\ \mathrm{C} & -4.32935800 & -1.42858500 & 0.17128400 \\ \mathrm{H} & -5.91823900 & -0.45902000 & -0.94804000 \\ \mathrm{H} & -4.44040300 & 1.42271500 & -1.67747200 \\ \mathrm{H} & -2.09965400 & 1.51890000 & -0.99476400 \\ \mathrm{H} & -2.58828100 & -2.17165800 & 1.19452000 \\ \mathrm{H} & -4.95281800 & -2.26164500 & 0.48971600 \\ \mathrm{C} & -0.76400200 & -0.33218600 & 0.61315400 \\ \mathrm{C} & 0.11345500 & 0.84941900 & 0.33623000 \\ \mathrm{C} & -0.25291600 & 2.13361900 & 0.77352600 \\ \mathrm{C} & 1.35792900 & 0.71827200 & -0.31305500 \\ \mathrm{C} & 0.56972200 & 3.24199600 & 0.59024400 \\ \mathrm{H} & -1.20829900 & 2.25054400 & 1.27979900 \\ \mathrm{C} & 2.17770200 & 1.83077300 & -0.51814600 \\ \mathrm{C} & 1.79583700 & 3.09073600 & -0.05944500 \\ \mathrm{H} & 0.25641300 & 4.21671500 & 0.95243900 \\ \mathrm{H} & 3.11088200 & 1.70057200 & -1.05765800 \\ \mathrm{H} & 2.44568700 & 3.94567100 & -0.22073000 \\ \mathrm{O} & -0.26809100 & -1.32522900 & 1.25366100 \\ \mathrm{O} & 1.70715200 & -0.49604100 & -0.84827500 \\ \mathrm{C} & 2.75596700 & -1.29979000 & -0.23306200 \\ \mathrm{C} & 2.25650900 & -2.73285900 & -0.38164200 \\ \mathrm{C} & 4.04916500 & -1.09201300 & -1.02039700 \\ \mathrm{C} & 2.94716600 & -0.95676600 & 1.24069700 \\ \mathrm{H} & 1.32098100 & -2.83808100 & 0.17436900 \\ \mathrm{H} & 2.07483600 & -2.95816000 & -1.43767600 \\ \mathrm{H} & 2.99908800 & -3.43952800 & 0.00230600 \\ \mathrm{H} & 4.43118800 & -0.07468600 & -0.89482200 \\ \mathrm{H} & 4.81834000 & -1.78716100 & -0.66788300 \\ \mathrm{H} & 3.87657200 & -1.27432000 & -2.08555700 \\ \mathrm{H} & 3.65718100 & -1.66631100 & 1.67713600 \\ \mathrm{H} & 3.35217800 & 0.05142700 & 1.37168300 \\ \mathrm{H} & 1.98563000 & -1.03564500 & 1.75515300\end{array}$


Reactant Complex for formation of $\mathbf{2 4}$ from $\mathbf{2 0}$ and

$\mathrm{O} t \mathrm{Bu}$ anion

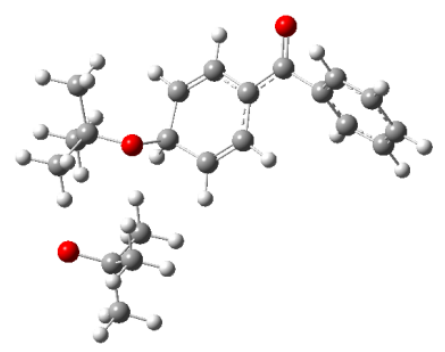

52

$-1042.5299146$

\begin{tabular}{|c|c|c|c|}
\hline 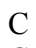 & -6.20090 & 2.02091 & 0.9515 \\
\hline $\mathrm{C}$ & -5.19761 & 2.46783 & 0.0919 \\
\hline $\mathrm{C}$ & -4.28256 & 1.56288 & $-0.448^{\circ}$ \\
\hline $\mathrm{C}$ & -4.36398 & 0.19923 & -0.146 \\
\hline $\mathrm{C}$ & -5.38998 & -0.24139 & 0.697 \\
\hline $\mathrm{C}$ & -6.29448 & 0.66087 & 1.254 \\
\hline $\mathrm{H}$ & -6.90877 & 2.72568 & 1.377 \\
\hline $\mathrm{H}$ & -5.12643 & 3.52212 & -0.159 \\
\hline $\mathrm{H}$ & -3.50269 & 1.91441 & -1.119 \\
\hline $\mathrm{H}$ & -5.46938 & -1.30313 & 0.914 \\
\hline $\mathrm{H}$ & -7.07479 & 0.30444 & 1.920 \\
\hline $\mathrm{C}$ & -3.44191 & -0.82747 & -0.767 \\
\hline $\mathrm{C}$ & -2.04136 & -0.66037 & -0.676 \\
\hline $\mathrm{C}$ & -1.37771 & 0.37039 & 0.086 \\
\hline $\mathrm{C}$ & -1.16865 & -1.55071 & -1.40 \\
\hline $\mathrm{C}$ & -0.02888 & 0.45577 & 0.188 \\
\hline $\mathrm{H}$ & -1.98010 & 1.11828 & $0.59^{\prime}$ \\
\hline $\mathrm{C}$ & 0.18263 & -1.49162 & -1.32 \\
\hline $\mathrm{H}$ & -1.63867 & -2.26372 & -2.07 \\
\hline $\mathrm{C}$ & 0.90073 & -0.58472 & -0.36 \\
\hline $\mathrm{H}$ & 0.42866 & 1.25979 & 0.76 \\
\hline $\mathrm{H}$ & 0.78485 & -2.14027 & -1.95 \\
\hline $\mathrm{O}$ & -4.01354 & -1.80342 & -1.33 \\
\hline $\mathrm{H}$ & 1.76196 & -0.10513 & -0.84 \\
\hline $\mathrm{O}$ & 1.43592 & -1.28049 & 0.802 \\
\hline $\mathrm{C}$ & 2.52872 & -2.20309 & 0.664 \\
\hline $\mathrm{C}$ & 3.26009 & -2.12434 & 2.00 \\
\hline $\mathrm{C}$ & 1.98152 & -3.62213 & 0.46 \\
\hline $\mathrm{C}$ & 3.50246 & -1.83778 & -0.458 \\
\hline $\mathrm{H}$ & 3.67462 & -1.12117 & 2.14 \\
\hline $\mathrm{H}$ & 2.56427 & -2.33586 & 2.824 \\
\hline $\mathrm{H}$ & 4.07780 & -2.85177 & 2.04 \\
\hline $\mathrm{H}$ & 1.47434 & -3.72085 & -0.49 \\
\hline $\mathrm{H}$ & 2.79579 & -4.35454 & 0.50 \\
\hline $\mathrm{H}$ & 1.26249 & -3.85544 & 1.25 \\
\hline $\mathrm{H}$ & 4.32616 & -2.56061 & -0.45 \\
\hline $\mathrm{H}$ & 3.03020 & -1.89102 & -1.4 \\
\hline $\mathrm{H}$ & 3.93604 & -0.84016 & \\
\hline $\mathrm{O}$ & 5.58503 & 1.05348 & \\
\hline $\mathrm{C}$ & 4.64513 & 2.04276 & -0.136 \\
\hline $\mathrm{C}$ & 3.52141 & 1.89341 & 0.919 \\
\hline $\mathrm{C}$ & 5.27489 & 3.44660 & 0.04 \\
\hline $\mathrm{C}$ & 3.98281 & 2.00556 & -1.53 \\
\hline $\mathrm{H}$ & 3.03578 & 0.91566 & 0.8114 \\
\hline $\mathrm{H}$ & 3.95883 & 1.94288 & 1.924 \\
\hline $\mathrm{H}$ & 2.75033 & 2.67275 & 0.837 \\
\hline $\mathrm{H}$ & 6.06435 & 3.59104 & -0.703 \\
\hline $\mathrm{H}$ & 4.54455 & 4.26143 & -0.059 \\
\hline $\mathrm{H}$ & 5.73315 & 3.51698 & 1.038 \\
\hline $\mathrm{H}$ & 3.20385 & 2.77007 & -1.664 \\
\hline $\mathrm{H}$ & 4.74909 & 2.15586 & -2.30 \\
\hline $\mathrm{H}$ & 3.53006 & 1.02023 & -1.698 \\
\hline
\end{tabular}


Transition State for formation of $\mathbf{2 4}$ from $\mathbf{2 0}$ and $\mathrm{O} t \mathrm{Bu}$ anion

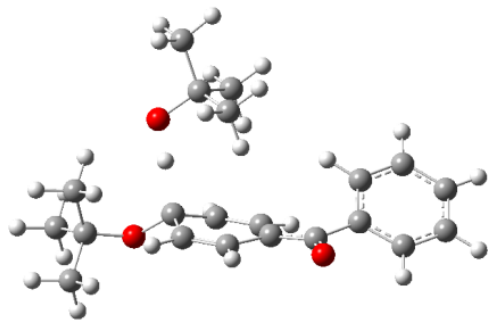

52

$-1042.4942279$

C $\quad 5.78637$

C $\quad 4.56433$

C $\quad 3.45989$

0.41966

$-1.15973$

$\begin{array}{ll}1.09537 & -1.12938\end{array}$

$\begin{array}{ll}0.52878 & -0.49443\end{array}$

$\begin{array}{lll}3.54209 & -0.72998 & 0.12591\end{array}$

$\begin{array}{llll}\text { C } & 4.78754 & -1.37928 & 0.11420\end{array}$

$\begin{array}{llll}\mathrm{C} & 5.89113 & -0.82260 & -0.52953\end{array}$

$\begin{array}{llll}\mathrm{H} & 6.64696 & 0.86117 & -1.65393\end{array}$

$\mathrm{H} \quad 4.47336 \quad 2.07521 \quad-1.59114$

$\begin{array}{llll}\mathrm{H} & 2.52083 & 1.07533 & -0.45775\end{array}$

$\begin{array}{llll}\mathrm{H} & 4.87148 & -2.33317 & 0.62678\end{array}$

$\begin{array}{llll}\mathrm{H} & 6.83861 & -1.35550 & -0.53509\end{array}$

$\begin{array}{llll}\text { C } & 2.40167 & -1.34314 & 0.89360\end{array}$

$\begin{array}{llll}\mathrm{C} & 1.09680 & -1.21430 & 0.42137\end{array}$

$\begin{array}{llll}\text { C } & 0.69680 & -0.74582 & -0.90622\end{array}$

$\begin{array}{llll}\text { C } & -0.02799 & -1.65507 & 1.24430\end{array}$

$\begin{array}{llll}\text { C } & -0.60051 & -0.51529 & -1.22599\end{array}$

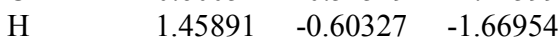

$\begin{array}{llll}\mathrm{C} & -1.32037 & -1.40514 & 0.91038\end{array}$

$\begin{array}{llll}\mathrm{H} & 0.20836 & -2.16514 & 2.17533\end{array}$

$\begin{array}{llll}\text { C } & -1.71768 & -0.58995 & -0.26193\end{array}$

$\begin{array}{llll}\mathrm{H} & -0.85226 & -0.19495 & -2.23840\end{array}$

$\begin{array}{llll}\mathrm{H} & -2.10194 & -1.74913 & 1.58809\end{array}$

$\begin{array}{llll}\mathrm{O} & 2.73043 & -1.95449 & 1.99021\end{array}$

$\begin{array}{llll}\mathrm{H} & -1.95906 & 0.86199 & 0.04933\end{array}$

$\begin{array}{llll}\mathrm{O} & -2.85772 & -1.13635 & -1.01053\end{array}$

$\begin{array}{llll}\text { C } & -4.17420 & -1.15363 & -0.46491\end{array}$

$\begin{array}{llll}\text { C } & -5.10196 & -0.84028 & -1.64300\end{array}$

$\begin{array}{llll}\text { C } & -4.48334 & -2.56798 & 0.04975\end{array}$

$\begin{array}{llll}\text { C } & -4.40909 & -0.12815 & 0.64475\end{array}$

$\begin{array}{llll}\mathrm{H} & -4.90798 & 0.17237 & -2.01144\end{array}$

$\mathrm{H} \quad-4.91907 \quad-1.54706 \quad-2.45926$

$\begin{array}{llll}\mathrm{H} & -6.15469 & -0.91260 & -1.34847\end{array}$

$\begin{array}{llll}\mathrm{H} & -3.82996 & -2.83337 & 0.88502\end{array}$

$\mathrm{H} \quad-5.52382 \quad-2.64088 \quad 0.38755$

$\begin{array}{llll}\mathrm{H} & -4.32648 & -3.29685 & -0.75223\end{array}$

$\begin{array}{llll}\mathrm{H} & -5.46138 & -0.17348 & 0.94828\end{array}$

$\begin{array}{llll}\mathrm{H} & -3.79028 & -0.33289 & 1.52296\end{array}$

$\begin{array}{llll}\mathrm{H} & -4.17283 & 0.88118 & 0.30269\end{array}$

$\begin{array}{llll}\text { O } & -2.18940 & 2.00964 & 0.18741\end{array}$

$\begin{array}{llll}\text { C } & -1.05391 & 2.79682 & 0.43933\end{array}$

$\begin{array}{llll}\text { C } & -0.27656 & 3.06761 & -0.85974\end{array}$

$\begin{array}{llll}\text { C } & -1.52813 & 4.13292 & 1.02495\end{array}$

$\begin{array}{llll}\text { C } & -0.12562 & 2.10050 & 1.44538\end{array}$

$\begin{array}{llll}\mathrm{H} & 0.06092 & 2.11871 & -1.28925\end{array}$

$\begin{array}{llll}\mathrm{H} & -0.92741 & 3.56992 & -1.58522\end{array}$

$\begin{array}{llll}\mathrm{H} & 0.59992 & 3.70365 & -0.68066\end{array}$

$\begin{array}{llll}\mathrm{H} & -2.07412 & 3.95806 & 1.95870\end{array}$

$\begin{array}{llll}\mathrm{H} & -0.68639 & 4.80463 & 1.23490\end{array}$

$\begin{array}{llll}\mathrm{H} & -2.20363 & 4.63186 & 0.32062\end{array}$

$\begin{array}{llll}\mathrm{H} & 0.74611 & 2.72357 & 1.68328\end{array}$

$\begin{array}{llll}\mathrm{H} & -0.67109 & 1.89911 & 2.37540\end{array}$

$\begin{array}{llll}\mathrm{H} & 0.22686 & 1.14490 & 1.04235\end{array}$ 
Product Complex of 24 and $\mathrm{HO}^{t} \mathrm{Bu}$

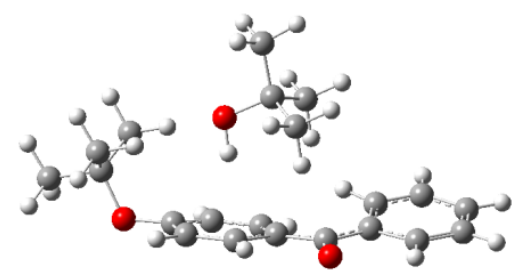

52

$-1042.5214805$

\begin{tabular}{|c|c|c|c|}
\hline $\mathrm{C}$ & 5.49302 & -0.79425 & -1.43145 \\
\hline $\mathrm{C}$ & 4.20920 & -0.89572 & -1.99563 \\
\hline $\mathrm{C}$ & 3.05680 & -0.89344 & -1.22192 \\
\hline $\mathrm{C}$ & 3.09117 & -0.79258 & 0.21819 \\
\hline $\mathrm{C}$ & 4.42263 & -0.62602 & 0.75421 \\
\hline $\mathrm{C}$ & 5.56122 & -0.64100 & -0.03494 \\
\hline $\mathrm{H}$ & 6.38653 & -0.80790 & -2.04793 \\
\hline $\mathrm{H}$ & 4.10231 & -0.96489 & -3.07795 \\
\hline $\mathrm{H}$ & 2.11436 & -0.91082 & -1.75274 \\
\hline $\mathrm{H}$ & 4.50156 & -0.49598 & 1.82758 \\
\hline $\mathrm{H}$ & 6.53317 & -0.52680 & 0.44514 \\
\hline $\mathrm{C}$ & 1.99714 & -0.76605 & 1.14669 \\
\hline $\mathrm{C}$ & 0.62852 & -1.03036 & 0.79838 \\
\hline $\mathrm{C}$ & 0.10469 & -1.60502 & -0.41591 \\
\hline $\mathrm{C}$ & -0.37866 & -0.78054 & 1.80242 \\
\hline $\mathrm{C}$ & -1.25479 & -1.78303 & -0.63008 \\
\hline $\mathrm{H}$ & 0.77325 & -1.98197 & -1.17803 \\
\hline $\mathrm{C}$ & -1.73696 & -0.96430 & 1.57161 \\
\hline $\mathrm{H}$ & -0.03239 & -0.42849 & 2.76729 \\
\hline $\mathrm{C}$ & -2.20602 & -1.42824 & 0.33729 \\
\hline $\mathrm{H}$ & -1.59857 & -2.22838 & -1.56239 \\
\hline $\mathrm{H}$ & -2.45703 & -0.74471 & 2.35854 \\
\hline $\mathrm{O}$ & 2.26235 & -0.46806 & 2.42553 \\
\hline $\mathrm{H}$ & -0.90555 & 1.06098 & 0.42430 \\
\hline $\mathrm{O}$ & -3.56237 & -1.65624 & 0.11620 \\
\hline $\mathrm{C}$ & -4.34686 & -0.56858 & -0.42872 \\
\hline $\mathrm{C}$ & -5.73157 & -1.17724 & -0.61933 \\
\hline $\mathrm{C}$ & -4.40247 & 0.59667 & 0.55793 \\
\hline $\mathrm{C}$ & -3.77347 & -0.10513 & -1.76664 \\
\hline $\mathrm{H}$ & -5.68089 & -2.02227 & -1.31304 \\
\hline $\mathrm{H}$ & -6.12096 & -1.53592 & 0.33863 \\
\hline $\mathrm{H}$ & -6.42544 & -0.43372 & -1.02272 \\
\hline $\mathrm{H}$ & -3.41176 & 1.03992 & 0.69266 \\
\hline $\mathrm{H}$ & -5.07634 & 1.37210 & 0.17843 \\
\hline $\mathrm{H}$ & -4.77642 & 0.25391 & 1.52850 \\
\hline $\mathrm{H}$ & -4.42880 & 0.65413 & -2.20594 \\
\hline $\mathrm{H}$ & -2.77958 & 0.33136 & -1.63162 \\
\hline $\mathrm{H}$ & -3.70010 & -0.94768 & -2.46234 \\
\hline $\mathrm{O}$ & -1.13420 & 1.94238 & 0.08095 \\
\hline $\mathrm{C}$ & 0.07747 & 2.68807 & -0.09801 \\
\hline $\mathrm{C}$ & 0.89043 & 2.06543 & -1.23180 \\
\hline $\mathrm{C}$ & -0.36498 & 4.10152 & -0.45783 \\
\hline $\mathrm{C}$ & 0.88604 & 2.67634 & 1.19923 \\
\hline $\mathrm{H}$ & 1.16678 & 1.04069 & -0.96327 \\
\hline $\mathrm{H}$ & 0.30232 & 2.05121 & -2.15609 \\
\hline $\mathrm{H}$ & 1.81176 & 2.63134 & -1.41114 \\
\hline $\mathrm{H}$ & -0.95763 & 4.53402 & 0.35488 \\
\hline $\mathrm{H}$ & 0.50563 & 4.74093 & -0.63391 \\
\hline $\mathrm{H}$ & -0.97615 & 4.08778 & -1.36633 \\
\hline $\mathrm{H}$ & 1.79709 & 3.27542 & 1.08775 \\
\hline $\mathrm{H}$ & 0.29105 & 3.10003 & 2.01607 \\
\hline $\mathrm{H}$ & 1.18036 & 1.65198 & 1.46223 \\
\hline
\end{tabular}


<smiles>CCCCO[Ge]1C=CC(=C([O-])c2ccccc2)C=C1</smiles>

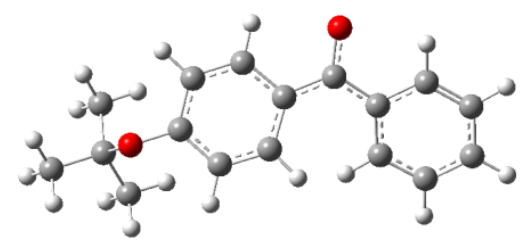

37

$-808.9229047$

\begin{tabular}{lrrr}
$\mathrm{C}$ & -5.45312 & -1.52396 & 0.16393 \\
$\mathrm{C}$ & -4.14562 & -2.04807 & 0.18962 \\
$\mathrm{C}$ & -3.02194 & -1.23778 & 0.14052 \\
$\mathrm{C}$ & -3.10816 & 0.20324 & 0.04794 \\
$\mathrm{C}$ & -4.46341 & 0.70752 & 0.11245 \\
$\mathrm{C}$ & -5.57214 & -0.12124 & 0.14823 \\
$\mathrm{H}$ & -6.32499 & -2.17024 & 0.19022 \\
$\mathrm{H}$ & -4.00160 & -3.12561 & 0.27037 \\
$\mathrm{H}$ & -2.05665 & -1.71947 & 0.24091 \\
$\mathrm{H}$ & -4.58352 & 1.78516 & 0.11932 \\
$\mathrm{H}$ & -6.56393 & 0.33148 & 0.17049 \\
$\mathrm{C}$ & -2.04132 & 1.15131 & 0.00044 \\
$\mathrm{C}$ & -0.66494 & 0.79507 & -0.23020 \\
$\mathrm{C}$ & -0.15238 & -0.44020 & -0.76060 \\
$\mathrm{C}$ & 0.34119 & 1.80300 & -0.02021 \\
$\mathrm{C}$ & 1.20558 & -0.66735 & -0.94157 \\
$\mathrm{H}$ & -0.83434 & -1.20969 & -1.10126 \\
$\mathrm{C}$ & 1.69674 & 1.55944 & -0.19495 \\
$\mathrm{H}$ & -0.00109 & 2.78330 & 0.29223 \\
$\mathrm{C}$ & 2.15884 & 0.30900 & -0.62223 \\
$\mathrm{H}$ & 1.54398 & -1.61360 & -1.36116 \\
$\mathrm{H}$ & 2.42273 & 2.34918 & -0.00618 \\
$\mathrm{O}$ & -2.32538 & 2.44767 & 0.19524 \\
$\mathrm{O}$ & 3.51722 & 0.08234 & -0.84345 \\
$\mathrm{C}$ & 4.29390 & -0.46312 & 0.24760 \\
$\mathrm{C}$ & 5.70195 & -0.57785 & -0.32562 \\
$\mathrm{C}$ & 4.28068 & 0.48492 & 1.44587 \\
$\mathrm{C}$ & 3.76810 & -1.84055 & 0.64863 \\
$\mathrm{H}$ & 5.70008 & -1.23520 & -1.20055 \\
$\mathrm{H}$ & 6.06596 & 0.40772 & -0.63187 \\
$\mathrm{H}$ & 6.38874 & -0.98882 & 0.42031 \\
$\mathrm{H}$ & 3.27107 & 0.58597 & 1.85373 \\
$\mathrm{H}$ & 4.93602 & 0.09939 & 2.23356 \\
$\mathrm{H}$ & 4.63670 & 1.47685 & 1.14915 \\
$\mathrm{H}$ & 4.41575 & -2.27786 & 1.41535 \\
$\mathrm{H}$ & 2.75367 & -1.77041 & 1.05073 \\
$\mathrm{H}$ & 3.75300 & -2.50849 & -0.21887 \\
& & & \\
\hline
\end{tabular}


Single Point Radical Anion using Optimised Geometry

24

37

$-808.8795541$

$\begin{array}{llll}\text { C } & -5.45312300 & -1.52395700 & 0.16393200\end{array}$

$\begin{array}{llll}\text { C } & -4.14562400 & -2.04807000 & 0.18961700\end{array}$

$\begin{array}{llll}\text { C } & -3.02194000 & -1.23777500 & 0.14052100\end{array}$

$\begin{array}{lllll}\text { C } & -3.10815800 & 0.20323700 & 0.04794100\end{array}$

$\begin{array}{llll}\text { C } & -4.46341400 & 0.70752300 & 0.11245500\end{array}$

$\begin{array}{llll}\mathrm{C} & -5.57214000 & -0.12123600 & 0.14823300\end{array}$

$\mathrm{H} \quad-6.32499400 \quad-2.17024000 \quad 0.19022300$

$\begin{array}{llll}\mathrm{H} & -4.00160300 & -3.12561300 & 0.27037100\end{array}$

$\begin{array}{llll}\mathrm{H} & -2.05664600 & -1.71946800 & 0.24090800\end{array}$

$\begin{array}{llll}\mathrm{H} & -4.58352000 & 1.78515800 & 0.11932000\end{array}$

$\begin{array}{lllll}\mathrm{H} & -6.56393000 & 0.33148000 & 0.17049200\end{array}$

$\begin{array}{llll}\text { C } & -2.04131600 & 1.15130600 & 0.00043700\end{array}$

$\begin{array}{llll}\mathrm{C} & -0.66493800 & 0.79507300 & -0.23020100\end{array}$

$\begin{array}{llll}\text { C } & -0.15237800 & -0.44020200 & -0.76060000\end{array}$

$\begin{array}{lllll}\mathrm{C} & 0.34119000 & 1.80300400 & -0.02020800\end{array}$

$\begin{array}{llll}\mathrm{C} & 1.20558300 & -0.66735400 & -0.94156900\end{array}$

$\mathrm{H} \quad-0.83434000 \quad-1.20969200 \quad-1.10125900$

$\begin{array}{llll}\mathrm{C} & 1.69674500 & 1.55943900 & -0.19494600\end{array}$

$\begin{array}{llll}\mathrm{H} & -0.00108600 & 2.78330500 & 0.29223300\end{array}$

$\begin{array}{llll}\mathrm{C} & 2.15883800 & 0.30899900 & -0.62222600\end{array}$

$\mathrm{H} \quad \begin{array}{llll}\mathrm{H} & 1.54397900 & -1.61360500 & -1.36116000\end{array}$

$\mathrm{H} \quad \begin{array}{llll}\mathrm{H} & 2.42272800 & 2.34918400 & -0.00618200\end{array}$

$\begin{array}{llll}\mathrm{O} & -2.32537900 & 2.44767000 & 0.19524300\end{array}$

$\begin{array}{llll}\text { O } & 3.51721500 & 0.08233500 & -0.84344800\end{array}$

$\begin{array}{llll}\mathrm{C} & 4.29390000 & -0.46311900 & 0.24759600\end{array}$

$\begin{array}{llll}\mathrm{C} & 5.70195200 & -0.57784900 & -0.32562000\end{array}$

$\begin{array}{llll}\mathrm{C} & 4.28068300 & 0.48492200 & 1.44586800\end{array}$

$\begin{array}{llll}\mathrm{C} & 3.76809600 & -1.84055500 & 0.64863000\end{array}$

$\mathrm{H} \quad \begin{array}{llll}\mathrm{H} & 5.70008300 & -1.23520100 & -1.20055400\end{array}$

$\mathrm{H} \quad \begin{array}{llll}\mathrm{H} & 6.06595800 & 0.40772000 & -0.63186500\end{array}$

$\begin{array}{llll}\mathrm{H} & 6.38874400 & -0.98882400 & 0.42031400\end{array}$

$\begin{array}{llll}\mathrm{H} & 3.27106600 & 0.58597100 & 1.85373100\end{array}$

$\begin{array}{llll}\mathrm{H} & 4.93602000 & 0.09939500 & 2.23355800\end{array}$

$\mathrm{H} \quad 4.63669800 \quad 1.47685100 \quad 1.14915000$

$\begin{array}{llll}\mathrm{H} & 4.41574600 & -2.27786000 & 1.41534800\end{array}$

$\begin{array}{llll}\mathrm{H} & 2.75367300 & -1.77041300 & 1.05072700\end{array}$

$\mathrm{H} \quad 3.75300200 \quad-2.50848700 \quad-0.21887200$ 


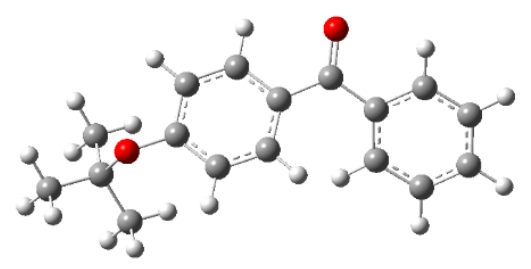

37

$-808.8876265$

\begin{tabular}{lccc}
$\mathrm{C}$ & -5.30743 & -1.62581 & 0.17207 \\
$\mathrm{C}$ & -3.99279 & -2.06245 & 0.37983 \\
$\mathrm{C}$ & -2.92481 & -1.17485 & 0.32528 \\
$\mathrm{C}$ & -3.12072 & 0.20545 & 0.05412 \\
$\mathrm{C}$ & -4.46551 & 0.63123 & -0.11331 \\
$\mathrm{C}$ & -5.52643 & -0.26318 & -0.06608 \\
$\mathrm{H}$ & -6.13713 & -2.32466 & 0.21071 \\
$\mathrm{H}$ & -3.79923 & -3.10925 & 0.60150 \\
$\mathrm{H}$ & -1.92848 & -1.54746 & 0.53913 \\
$\mathrm{H}$ & -4.64224 & 1.68750 & -0.28737 \\
$\mathrm{H}$ & -6.53949 & 0.10311 & -0.21541 \\
$\mathrm{C}$ & -2.06691 & 1.21913 & 0.02667 \\
$\mathrm{C}$ & -0.65164 & 0.87227 & -0.17069 \\
$\mathrm{C}$ & -0.18503 & -0.28980 & -0.83136 \\
$\mathrm{C}$ & 0.33238 & 1.80812 & 0.23030 \\
$\mathrm{C}$ & 1.17155 & -0.52334 & -1.02520 \\
$\mathrm{H}$ & -0.89504 & -0.99982 & -1.24217 \\
$\mathrm{C}$ & 1.68896 & 1.57348 & 0.04174 \\
$\mathrm{H}$ & -0.00343 & 2.73013 & 0.69363 \\
$\mathrm{C}$ & 2.12369 & 0.39390 & -0.56941 \\
$\mathrm{H}$ & 1.50662 & -1.41146 & -1.55445 \\
$\mathrm{H}$ & 2.42668 & 2.30495 & 0.36151 \\
$\mathrm{O}$ & -2.38155 & 2.45535 & 0.18532 \\
$\mathrm{O}$ & 3.46756 & 0.18562 & -0.81997 \\
$\mathrm{C}$ & 4.25410 & -0.50302 & 0.18762 \\
$\mathrm{C}$ & 5.64306 & -0.58312 & -0.43291 \\
$\mathrm{C}$ & 4.29070 & 0.30567 & 1.48268 \\
$\mathrm{C}$ & 3.69597 & -1.90172 & 0.44023 \\
$\mathrm{H}$ & 5.60734 & -1.14729 & -1.36953 \\
$\mathrm{H}$ & 6.02074 & 0.42176 & -0.64399 \\
$\mathrm{H}$ & 6.33625 & -1.08139 & 0.25094 \\
$\mathrm{H}$ & 3.29670 & 0.37913 & 1.93278 \\
$\mathrm{H}$ & 4.95647 & -0.18061 & 2.20230 \\
$\mathrm{H}$ & 4.66471 & 1.31627 & 1.29044 \\
$\mathrm{H}$ & 4.34861 & -2.43833 & 1.13560 \\
$\mathrm{H}$ & 2.69440 & -1.85476 & 0.87740 \\
$\mathrm{H}$ & 3.64378 & -2.46727 & -0.49542 \\
& & & \\
\hline
\end{tabular}


Single Point Dianion using

Optimised Geometry 25

37

$-808.9145670$

$\begin{array}{lccc}\mathrm{C} & -5.30742700 & -1.62580700 & 0.17206800 \\ \mathrm{C} & -3.99279400 & -2.06244900 & 0.37983400 \\ \mathrm{C} & -2.92480900 & -1.17485200 & 0.32528100 \\ \mathrm{C} & -3.12072300 & 0.20545400 & 0.05411800 \\ \mathrm{C} & -4.46550700 & 0.63122500 & -0.11330900 \\ \mathrm{C} & -5.52643200 & -0.26318000 & -0.06607900 \\ \mathrm{H} & -6.13712800 & -2.32465700 & 0.21071100 \\ \mathrm{H} & -3.79923400 & -3.10924700 & 0.60150300 \\ \mathrm{H} & -1.92847900 & -1.54745800 & 0.53912700 \\ \mathrm{H} & -4.64224300 & 1.68750100 & -0.28737300 \\ \mathrm{H} & -6.53948900 & 0.10310600 & -0.21541000 \\ \mathrm{C} & -2.06691500 & 1.21912500 & 0.02667200 \\ \mathrm{C} & -0.65163700 & 0.87226800 & -0.17069000 \\ \mathrm{C} & -0.18503000 & -0.28979700 & -0.83135800 \\ \mathrm{C} & 0.33237800 & 1.80811600 & 0.23030000 \\ \mathrm{C} & 1.17154600 & -0.52334500 & -1.02519600 \\ \mathrm{H} & -0.89503900 & -0.99982400 & -1.24217300 \\ \mathrm{C} & 1.68895600 & 1.57348300 & 0.04174400 \\ \mathrm{H} & -0.00342600 & 2.73012600 & 0.69363400 \\ \mathrm{C} & 2.12368600 & 0.39389800 & -0.56941200 \\ \mathrm{H} & 1.50662200 & -1.41145600 & -1.55444600 \\ \mathrm{H} & 2.42668500 & 2.30494800 & 0.36151300 \\ \mathrm{O} & -2.38155300 & 2.45535000 & 0.18532500 \\ \mathrm{O} & 3.46755600 & 0.18561600 & -0.81997300 \\ \mathrm{C} & 4.25409700 & -0.50301600 & 0.18762400 \\ \mathrm{C} & 5.64306000 & -0.58312200 & -0.43290800 \\ \mathrm{C} & 4.29069900 & 0.30567500 & 1.48267700 \\ \mathrm{C} & 3.69596900 & -1.90172300 & 0.44023200 \\ \mathrm{H} & 5.60733700 & -1.14728500 & -1.36953300 \\ \mathrm{H} & 6.02073500 & 0.42176300 & -0.64399300 \\ \mathrm{H} & 6.33625400 & -1.08139100 & 0.25094000 \\ \mathrm{H} & 3.29669800 & 0.37913000 & 1.93278400 \\ \mathrm{H} & 4.95646900 & -0.18060800 & 2.20229700 \\ \mathrm{H} & 4.66471100 & 1.31626600 & 1.29044100 \\ \mathrm{H} & 4.34861500 & -2.43833300 & 1.13560500 \\ \mathrm{H} & 2.69439500 & -1.85475600 & 0.87739500 \\ \mathrm{H} & 3.64377700 & -2.46727400 & -0.49542400 \\ & & & \\ & & & \\ \mathrm{H} & & & \end{array}$


Singlet Complex between 46 and $\mathbf{1 7}$ (no counterions)

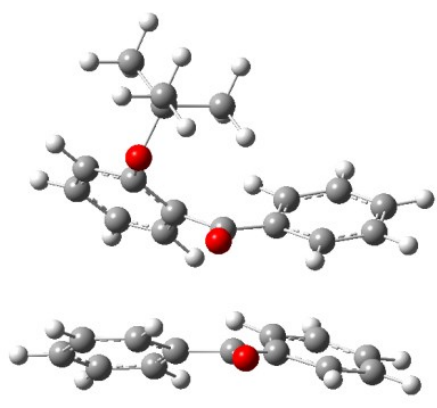

61

$-1385.3661018$

\begin{tabular}{|c|c|c|c|}
\hline $\mathrm{C}$ & 2.10253 & -3.76954 & 0.78342 \\
\hline $\mathrm{C}$ & 1.39720 & -3.00080 & 1.72273 \\
\hline $\mathrm{C}$ & 0.58367 & -1.94848 & 1.32329 \\
\hline $\mathrm{C}$ & 0.42428 & -1.61693 & -0.05019 \\
\hline $\mathrm{C}$ & 1.14512 & -2.40603 & -0.98594 \\
\hline $\mathrm{C}$ & 1.96408 & -3.44836 & -0.57520 \\
\hline $\mathrm{H}$ & 2.72950 & -4.59784 & 1.09980 \\
\hline $\mathrm{H}$ & 1.47877 & -3.23342 & 2.78256 \\
\hline $\mathrm{H}$ & 0.02522 & -1.40803 & 2.08153 \\
\hline $\mathrm{H}$ & 1.03270 & -2.16232 & -2.03662 \\
\hline $\mathrm{H}$ & 2.50757 & -4.02313 & -1.32283 \\
\hline $\mathrm{C}$ & -0.54220 & -0.64943 & -0.56822 \\
\hline $\mathrm{C}$ & -1.33043 & 0.18656 & 0.39015 \\
\hline $\mathrm{C}$ & -0.69362 & 0.90351 & 1.41773 \\
\hline $\mathrm{C}$ & -2.72927 & 0.35487 & 0.27123 \\
\hline $\mathrm{C}$ & -1.37441 & 1.77149 & 2.26102 \\
\hline $\mathrm{H}$ & 0.38173 & 0.79607 & 1.51077 \\
\hline $\mathrm{C}$ & -3.41303 & 1.25139 & 1.09826 \\
\hline $\mathrm{C}$ & -2.74772 & 1.96717 & 2.09105 \\
\hline $\mathrm{H}$ & -0.82826 & 2.32412 & 3.02049 \\
\hline $\mathrm{H}$ & -4.48245 & 1.36991 & 0.94749 \\
\hline $\mathrm{H}$ & -3.29392 & 2.66292 & 2.72134 \\
\hline $\mathrm{O}$ & -0.85046 & -0.63462 & -1.78819 \\
\hline $\mathrm{O}$ & -3.47182 & -0.30979 & -0.68268 \\
\hline $\mathrm{C}$ & -4.02768 & -1.60594 & -0.34906 \\
\hline $\mathrm{C}$ & -4.73116 & -2.03086 & -1.63259 \\
\hline $\mathrm{C}$ & -2.93220 & -2.60635 & 0.01316 \\
\hline $\mathrm{C}$ & -5.03665 & -1.48084 & 0.79314 \\
\hline $\mathrm{H}$ & -5.50158 & -1.30159 & -1.90179 \\
\hline $\mathrm{H}$ & -4.00888 & -2.09630 & -2.45131 \\
\hline $\mathrm{H}$ & -5.20366 & -3.00871 & -1.50055 \\
\hline $\mathrm{H}$ & -2.39539 & -2.30264 & 0.91785 \\
\hline $\mathrm{H}$ & -3.38481 & -3.58650 & 0.19637 \\
\hline $\mathrm{H}$ & -2.20668 & -2.68921 & -0.80039 \\
\hline $\mathrm{H}$ & -5.51561 & -2.44970 & 0.96600 \\
\hline $\mathrm{H}$ & -4.54850 & -1.17105 & 1.72186 \\
\hline $\mathrm{H}$ & -5.81166 & -0.74873 & 0.54353 \\
\hline $\mathrm{C}$ & 5.07151 & -0.86219 & 0.95012 \\
\hline $\mathrm{C}$ & 4.13341 & -0.07029 & 1.63389 \\
\hline $\mathrm{C}$ & 3.09671 & 0.56066 & 0.95986 \\
\hline $\mathrm{C}$ & 2.94245 & 0.45461 & -0.45052 \\
\hline $\mathrm{C}$ & 3.88111 & -0.38842 & -1.11248 \\
\hline $\mathrm{C}$ & 4.91927 & -1.01292 & -0.43371 \\
\hline $\mathrm{H}$ & 5.88549 & -1.34689 & 1.48111 \\
\hline $\mathrm{H}$ & 4.20139 & 0.03735 & 2.71461 \\
\hline $\mathrm{H}$ & 2.37985 & 1.12279 & 1.54733 \\
\hline $\mathrm{H}$ & 3.76668 & -0.51360 & -2.18370 \\
\hline $\mathrm{H}$ & 5.61832 & -1.63657 & -0.98826 \\
\hline $\mathrm{C}$ & 1.90285 & 1.06991 & -1.27272 \\
\hline $\mathrm{C}$ & 1.13047 & 2.23977 & -0.82753 \\
\hline $\mathrm{C}$ & 1.50163 & 3.12910 & 0.21229 \\
\hline $\mathrm{C}$ & -0.02384 & 2.59422 & -1.57454 \\
\hline
\end{tabular}




$\begin{array}{lrrc}\mathrm{C} & 0.74713 & 4.26017 & 0.51103 \\ \mathrm{H} & 2.42179 & 2.96797 & 0.76281 \\ \mathrm{C} & -0.78115 & 3.71489 & -1.26184 \\ \mathrm{H} & -0.31533 & 1.92808 & -2.37993 \\ \mathrm{C} & -0.41194 & 4.56615 & -0.20943 \\ \mathrm{H} & 1.07918 & 4.92107 & 1.30922 \\ \mathrm{H} & -1.67474 & 3.93398 & -1.84338 \\ \mathrm{H} & -0.99893 & 5.44877 & 0.02744 \\ \mathrm{O} & 1.77896 & 0.69448 & -2.49333\end{array}$


Single Point Triplet, Using Singlet Complex (of $\mathbf{4 6}$ and 17 , no counterions)

Optimised Geometry

61

$-1385.3661697$

\begin{tabular}{|c|c|c|c|}
\hline & 2.10253 & -3.76954 & 0.78342 \\
\hline $\mathrm{C}$ & 1.39720 & -3.00080 & 1.72273 \\
\hline $\mathrm{C}$ & 0.58367 & -1.94848 & 1.32329 \\
\hline $\mathrm{C}$ & 0.42428 & -1.61693 & -0.05019 \\
\hline $\mathrm{C}$ & 1.14512 & -2.40603 & -0.98594 \\
\hline $\mathrm{C}$ & 1.96408 & -3.44836 & -0.57520 \\
\hline $\mathrm{H}$ & 2.72950 & -4.59784 & 1.09980 \\
\hline $\mathrm{H}$ & 1.47877 & -3.23342 & 2.78256 \\
\hline $\mathrm{H}$ & 0.02522 & -1.40803 & 2.0815 \\
\hline $\mathrm{H}$ & 1.03270 & -2.16232 & -2.03662 \\
\hline $\mathrm{H}$ & 2.50757 & -4.02313 & -1.32283 \\
\hline $\mathrm{C}$ & -0.54220 & -0.64943 & -0.56822 \\
\hline $\mathrm{C}$ & -1.33043 & 0.18656 & 0.39015 \\
\hline $\mathrm{C}$ & -0.69362 & 0.90351 & 1.4177 \\
\hline $\mathrm{C}$ & -2.72927 & 0.35487 & 0.2712 \\
\hline $\mathrm{C}$ & -1.37441 & 1.77149 & 2.26102 \\
\hline $\mathrm{H}$ & 0.38173 & 0.79607 & 1.51077 \\
\hline $\mathrm{C}$ & -3.41303 & 1.25139 & 1.09826 \\
\hline $\mathrm{C}$ & -2.74772 & 1.96717 & 2.0910 \\
\hline $\mathrm{H}$ & -0.82826 & 2.32412 & 3.0204 \\
\hline $\mathrm{H}$ & -4.48245 & 1.36991 & 0.9474 \\
\hline $\mathrm{H}$ & -3.29392 & 2.66292 & 2.7213 \\
\hline $\mathrm{O}$ & -0.85046 & -0.63462 & -1.7881 \\
\hline $\mathrm{O}$ & -3.47182 & -0.30979 & -0.6826 \\
\hline $\mathrm{C}$ & -4.02768 & -1.60594 & -0.3490 \\
\hline $\mathrm{C}$ & -4.73116 & -2.03086 & -1.6325 \\
\hline $\mathrm{C}$ & -2.93220 & -2.60635 & 0.01316 \\
\hline $\mathrm{C}$ & -5.03665 & -1.48084 & 0.79314 \\
\hline $\mathrm{H}$ & -5.50158 & -1.30159 & -1.90179 \\
\hline $\mathrm{H}$ & -4.00888 & -2.09630 & -2.45131 \\
\hline $\mathrm{H}$ & -5.20366 & -3.00871 & -1.5005 \\
\hline $\mathrm{H}$ & -2.39539 & -2.30264 & 0.91785 \\
\hline $\mathrm{H}$ & -3.38481 & -3.58650 & 0.19637 \\
\hline $\mathrm{H}$ & -2.20668 & -2.68921 & -0.80039 \\
\hline $\mathrm{H}$ & -5.51561 & -2.44970 & 0.96600 \\
\hline $\mathrm{H}$ & -4.54850 & -1.17105 & 1.72186 \\
\hline $\mathrm{H}$ & -5.81166 & -0.74873 & 0.54353 \\
\hline $\mathrm{C}$ & 5.07151 & -0.86219 & 0.95012 \\
\hline $\mathrm{C}$ & 4.13341 & -0.07029 & 1.6338 \\
\hline $\mathrm{C}$ & 3.09671 & 0.56066 & 0.95986 \\
\hline $\mathrm{C}$ & 2.94245 & 0.45461 & -0.45052 \\
\hline $\mathrm{C}$ & 3.88111 & -0.38842 & -1.1124 \\
\hline $\mathrm{C}$ & 4.91927 & -1.01292 & -0.4337 \\
\hline $\mathrm{H}$ & 5.88549 & -1.34689 & 1.4811 \\
\hline $\mathrm{H}$ & 4.20139 & 0.03735 & 2.7146 \\
\hline $\mathrm{H}$ & 2.37985 & 1.12279 & 1.5473 \\
\hline $\mathrm{H}$ & 3.76668 & -0.51360 & -2.183 \\
\hline $\mathrm{H}$ & 5.61832 & -1.63657 & -0.9882 \\
\hline C & 1.90285 & 1.06991 & -1.2727 \\
\hline $\mathrm{C}$ & 1.13047 & 2.23977 & -0.8275 \\
\hline $\mathrm{C}$ & 1.50163 & 3.12910 & 0.2122 \\
\hline C & -0.02384 & 2.59422 & -1.5745 \\
\hline$C$ & 0.74713 & 4.26017 & 0.5110 \\
\hline 11 & 2.42179 & 2.96797 & 0.7628 \\
\hline & -0.78115 & 3.71489 & -1.2618 \\
\hline & -0.31533 & 1.92808 & -2.3799 \\
\hline & -0.41194 & 4.56615 & -0.2094 \\
\hline & 1.07918 & 4.92107 & 1.3092 \\
\hline & -1.67474 & 3.93398 & -1.8433 \\
\hline & -0.99893 & 5.44877 & 0.027 \\
\hline
\end{tabular}


Triplet Complex between 46 and $\mathbf{1 7}$ (no counterions)

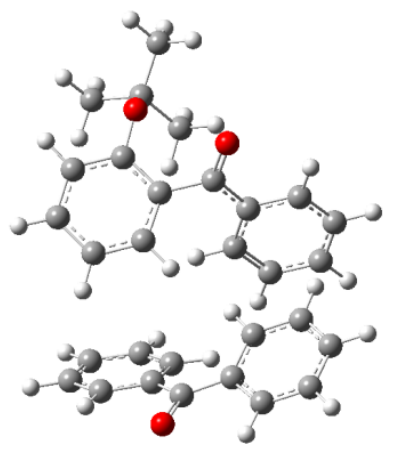

61

$-1385.3909734$

\begin{tabular}{|c|c|c|c|}
\hline C & -0.32054 & 3.28662 & 2.37139 \\
\hline $\mathrm{C}$ & -0.21122 & 1.88413 & 2.36881 \\
\hline $\mathrm{C}$ & 0.39681 & 1.21017 & 1.32235 \\
\hline C & 0.92311 & 1.90722 & 0.19123 \\
\hline C & 0.82347 & 3.33348 & 0.22639 \\
\hline C & 0.21881 & 3.99367 & 1.28554 \\
\hline $\mathrm{H}$ & -0.80278 & 3.80620 & 3.1933 \\
\hline $\mathrm{H}$ & -0.61023 & 1.30982 & 3.2033 \\
\hline $\mathrm{H}$ & 0.46433 & 0.12627 & 1.3677 \\
\hline $\mathrm{H}$ & 1.23526 & 3.89132 & -0.608 \\
\hline $\mathrm{H}$ & 0.15728 & 5.08017 & 1.2676 \\
\hline C & 1.60460 & 1.27876 & -0.9115 \\
\hline 0 & 1.68977 & -0.21477 & $-0.971 \mathrm{~s}$ \\
\hline $\mathrm{C}$ & 0.52507 & -1.00170 & -0.9367 \\
\hline C & 2.91599 & -0.89452 & -1.1341 \\
\hline C & 0.55465 & -2.38759 & -1.063 \\
\hline $\mathrm{H}$ & -0.43464 & -0.50595 & -0.817 \\
\hline $\mathrm{C}$ & 2.94817 & -2.28208 & -1.2967 \\
\hline $\mathrm{C}$ & 1.77543 & -3.03493 & $-1.256^{\circ}$ \\
\hline $\mathrm{H}$ & -0.37480 & -2.94828 & -1.013 \\
\hline $\mathrm{H}$ & 3.91111 & -2.76044 & -1.4503 \\
\hline $\mathrm{H}$ & 1.81777 & -4.11354 & -1.3770 \\
\hline $\mathrm{O}$ & 2.15890 & 1.96505 & -1.8395 \\
\hline $\mathrm{O}$ & 4.10772 & -0.20402 & -1.199 \\
\hline $\mathrm{C}$ & 4.87802 & -0.01866 & 0.0146 \\
\hline $\mathrm{C}$ & 6.04037 & 0.85665 & -0.4378 \\
\hline $\mathrm{C}$ & 4.05891 & 0.69584 & 1.0867 \\
\hline $\mathrm{C}$ & 5.39105 & -1.35991 & 0.5391 \\
\hline $\mathrm{H}$ & 6.61915 & 0.34636 & -1.2139 \\
\hline $\mathrm{H}$ & 5.65930 & 1.79716 & $-0.846 ?$ \\
\hline $\mathrm{H}$ & 6.70095 & 1.07858 & 0.4054 \\
\hline $\mathrm{H}$ & 3.18492 & 0.10576 & 1.3820 \\
\hline $\mathrm{H}$ & 4.68180 & 0.85172 & 1.9737 \\
\hline$H$ & 3.70637 & 1.66420 & 0.7219 \\
\hline H & 6.05863 & -1.18935 & 1.3896 \\
\hline & 4.56742 & -1.99607 & 0.875 \\
\hline & 5.94849 & -1.88855 & -0.2407 \\
\hline & -4.01173 & 3.08433 & -1.047 \\
\hline 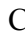 & -2.85430 & 2.49392 & -0.527 \\
\hline 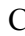 & -2.79134 & 1.12157 & -0.31013 \\
\hline C & -3.88740 & 0.27074 & -0.5962 \\
\hline $\mathrm{C}$ & -5.03641 & 0.88767 & -1.1523 \\
\hline & -5.09821 & 2.26017 & -1.3638 \\
\hline & -4.06107 & 4.15610 & -1.214 \\
\hline & -1.97805 & 3.09540 & -0.292 \\
\hline & -1.85756 & 0.71881 & 0.0618 \\
\hline & -5.87739 & 0.25218 & -1.409 \\
\hline & -6.00332 & 2.69515 & -1.781 \\
\hline & -3.89504 & -1.19199 & -0.441 \\
\hline
\end{tabular}




$\begin{array}{llll}\mathrm{C} & -2.95486 & -1.90242 & 0.43006 \\ \mathrm{C} & -2.21782 & -1.32408 & 1.49677 \\ \mathrm{C} & -2.82561 & -3.30787 & 0.26513 \\ \mathrm{C} & -1.37371 & -2.08785 & 2.29391 \\ \mathrm{H} & -2.32699 & -0.27031 & 1.72871 \\ \mathrm{C} & -1.98050 & -4.06436 & 1.06663 \\ \mathrm{H} & -3.40515 & -3.77845 & -0.52241 \\ \mathrm{C} & -1.23025 & -3.46490 & 2.08523 \\ \mathrm{H} & -0.82706 & -1.60059 & 3.09874 \\ \mathrm{H} & -1.89836 & -5.13515 & 0.89356 \\ \mathrm{H} & -0.56497 & -4.05538 & 2.70773 \\ \mathrm{O} & -4.76940 & -1.87314 & -1.09315\end{array}$


Single Point Singlet, Using Triplet Complex (of $\mathbf{4 6}$ and

17 , no counterions)

Optimised Geometry

61

$-1385.3505837$

\begin{tabular}{|c|c|c|c|}
\hline $\mathrm{C}$ & -0.32054 & 3.28662 & 2.37139 \\
\hline $\mathrm{C}$ & -0.21122 & 1.88413 & 2.36881 \\
\hline $\mathrm{C}$ & 0.39681 & 1.21017 & 1.32235 \\
\hline $\mathrm{C}$ & 0.92311 & 1.90722 & 0.19123 \\
\hline $\mathrm{C}$ & 0.82347 & 3.33348 & 0.22639 \\
\hline $\mathrm{C}$ & 0.21881 & 3.99367 & 1.28554 \\
\hline $\mathrm{H}$ & -0.80278 & 3.80620 & 3.19335 \\
\hline $\mathrm{H}$ & -0.61023 & 1.30982 & 3.20335 \\
\hline $\mathrm{H}$ & 0.46433 & 0.12627 & 1.36772 \\
\hline $\mathrm{H}$ & 1.23526 & 3.89132 & -0.60891 \\
\hline $\mathrm{H}$ & 0.15728 & 5.08017 & 1.26766 \\
\hline $\mathrm{C}$ & 1.60460 & 1.27876 & -0.91153 \\
\hline $\mathrm{C}$ & 1.68977 & -0.21477 & -0.97196 \\
\hline $\mathrm{C}$ & 0.52507 & -1.00170 & -0.93673 \\
\hline $\mathrm{C}$ & 2.91599 & -0.89452 & -1.13417 \\
\hline $\mathrm{C}$ & 0.55465 & -2.38759 & -1.06306 \\
\hline $\mathrm{H}$ & -0.43464 & -0.50595 & -0.81708 \\
\hline $\mathrm{C}$ & 2.94817 & -2.28208 & -1.29677 \\
\hline $\mathrm{C}$ & 1.77543 & -3.03493 & -1.25676 \\
\hline $\mathrm{H}$ & -0.37480 & -2.94828 & -1.01394 \\
\hline $\mathrm{H}$ & 3.91111 & -2.76044 & -1.45031 \\
\hline $\mathrm{H}$ & 1.81777 & -4.11354 & -1.37701 \\
\hline $\mathrm{O}$ & 2.15890 & 1.96505 & -1.83958 \\
\hline $\mathrm{O}$ & 4.10772 & -0.20402 & -1.19966 \\
\hline $\mathrm{C}$ & 4.87802 & -0.01866 & 0.01465 \\
\hline $\mathrm{C}$ & 6.04037 & 0.85665 & -0.43789 \\
\hline $\mathrm{C}$ & 4.05891 & 0.69584 & 1.08674 \\
\hline $\mathrm{C}$ & 5.39105 & -1.35991 & 0.53914 \\
\hline $\mathrm{H}$ & 6.61915 & 0.34636 & -1.21391 \\
\hline $\mathrm{H}$ & 5.65930 & 1.79716 & -0.84634 \\
\hline $\mathrm{H}$ & 6.70095 & 1.07858 & 0.40540 \\
\hline $\mathrm{H}$ & 3.18492 & 0.10576 & 1.38202 \\
\hline $\mathrm{H}$ & 4.68180 & 0.85172 & 1.97370 \\
\hline $\mathrm{H}$ & 3.70637 & 1.66420 & 0.72194 \\
\hline $\mathrm{H}$ & 6.05863 & -1.18935 & 1.38962 \\
\hline $\mathrm{H}$ & 4.56742 & -1.99607 & 0.87595 \\
\hline $\mathrm{H}$ & 5.94849 & -1.88855 & -0.24073 \\
\hline $\mathrm{C}$ & -4.01173 & 3.08433 & -1.04743 \\
\hline $\mathrm{C}$ & -2.85430 & 2.49392 & -0.52758 \\
\hline $\mathrm{C}$ & -2.79134 & 1.12157 & -0.31013 \\
\hline $\mathrm{C}$ & -3.88740 & 0.27074 & -0.59621 \\
\hline $\mathrm{C}$ & -5.03641 & 0.88767 & -1.15233 \\
\hline $\mathrm{C}$ & -5.09821 & 2.26017 & -1.36384 \\
\hline $\mathrm{H}$ & -4.06107 & 4.15610 & -1.21480 \\
\hline $\mathrm{H}$ & -1.97805 & 3.09540 & -0.29241 \\
\hline $\mathrm{H}$ & -1.85756 & 0.71881 & 0.06180 \\
\hline $\mathrm{H}$ & -5.87739 & 0.25218 & -1.40981 \\
\hline $\mathrm{H}$ & -6.00332 & 2.69515 & -1.78153 \\
\hline $\mathrm{C}$ & -3.89504 & -1.19199 & -0.44141 \\
\hline $\mathrm{C}$ & -2.95486 & -1.90242 & 0.43006 \\
\hline $\mathrm{C}$ & -2.21782 & -1.32408 & 1.49677 \\
\hline $\mathrm{C}$ & -2.82561 & -3.30787 & 0.26513 \\
\hline $\mathrm{C}$ & -1.37371 & -2.08785 & 2.29391 \\
\hline $\mathrm{H}$ & -2.32699 & -0.27031 & 1.72871 \\
\hline $\mathrm{C}$ & -1.98050 & -4.06436 & 1.06663 \\
\hline $\mathrm{H}$ & -3.40515 & -3.77845 & -0.52241 \\
\hline $\mathrm{C}$ & -1.23025 & -3.46490 & 2.08523 \\
\hline $\mathrm{H}$ & -0.82706 & -1.60059 & 3.09874 \\
\hline $\mathrm{H}$ & -1.89836 & -5.13515 & 0.89356 \\
\hline $\mathrm{H}$ & -0.56497 & -4.05538 & 2.70773 \\
\hline
\end{tabular}


$\begin{array}{lll}-4.76940 & -1.87314 & -1.09315\end{array}$ 
Singlet Complex between $\mathbf{4 6}$ and 17 (counterions)

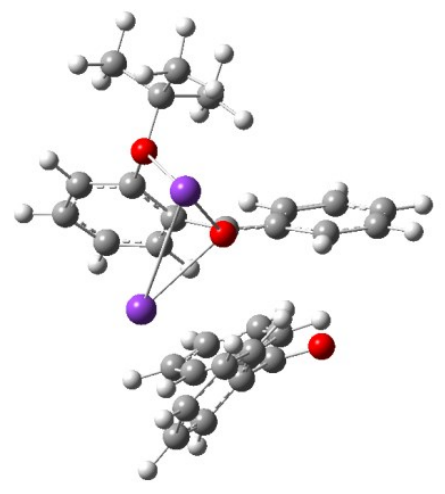

63

$-2585.0745194$

$\begin{array}{llll}\mathrm{C} & 0.84795900 & -3.29825300 & -3.26774500\end{array}$

$\begin{array}{llll}\mathrm{C} & 0.53231300 & -3.64211700 & -1.94275600\end{array}$

C $\quad 0.11927600 \quad-2.68372500 \quad-1.03084300$

$\begin{array}{llll}\text { C } & -0.00776500 & -1.30897600 & -1.39430500\end{array}$

$\begin{array}{llll}\text { C } & 0.32516300 & -0.98573300 & -2.74259900\end{array}$

C $\quad 0.72775200 \quad-1.95809900 \quad-3.64906200$

$\mathrm{H} \quad \begin{array}{llll}\mathrm{C} & 1.16959900 & -4.05471600 & -3.97717700\end{array}$

$\mathrm{H} \quad \begin{array}{llll}1.60425900 & -4.67898600 & -1.62069300\end{array}$

$\mathrm{H} \quad-0.15424200 \quad-3.00602300 \quad-0.03094700$

$\mathrm{H} \quad \begin{array}{llll}\mathrm{H} & 0.22719500 & 0.04712500 & -3.05826500\end{array}$

$\mathrm{H} \quad 0.96615300 \quad-1.66527300 \quad-4.66968300$

$\begin{array}{llll}\text { C } & -0.54563700 & -0.28369100 & -0.54555900\end{array}$

$\begin{array}{llll}\mathrm{C} & -0.98688900 & -0.57553800 & 0.82709100\end{array}$

$\begin{array}{lllll}\text { C } & & -0.16853800 & -1.24201200 & 1.77087800\end{array}$

$\begin{array}{llll}\text { C } & -2.21947800 & -0.05441700 & 1.33195900\end{array}$

$\begin{array}{llll}\text { C } & -0.47472000 & -1.27824100 & 3.12826300\end{array}$

$\mathrm{H} \quad \begin{array}{llll}\mathrm{H} & 0.76111100 & -1.67785400 & 1.42422300\end{array}$

$\begin{array}{llll}\text { C } & -2.49964300 & -0.05477600 & 2.69481700\end{array}$

$\begin{array}{llll}\mathrm{C} & -1.62647700 & -0.65061100 & 3.61227400\end{array}$

$\begin{array}{llll}\mathrm{H} & 0.21376800 & -1.76853400 & 3.81188300\end{array}$

$\mathrm{H} \quad \begin{array}{llll}\mathrm{H} & -3.43550500 & 0.38649800 & 3.02764800\end{array}$

$\mathrm{H} \quad-1.85587200 \quad-0.64080600 \quad 4.67279800$

$\begin{array}{lllll}\mathrm{O} & -0.84456000 & 0.90260600 & -1.02369300\end{array}$

$\begin{array}{lllll}\mathrm{O} & -3.19201100 & 0.43687900 & 0.46729900\end{array}$

$\begin{array}{lllll}\text { C } & -4.18303800 & -0.52993500 & -0.00412500\end{array}$

$\begin{array}{lllll}\text { C } & -5.00347800 & 0.24401300 & -1.02947400\end{array}$

$\begin{array}{llll}\text { C } & -3.50988300 & -1.72790700 & -0.66849900\end{array}$

$\begin{array}{llll}\text { C } & -5.08052700 & -0.97928000 & 1.14740400\end{array}$

$\mathrm{H} \quad-5.38824400 \quad 1.17301500 \quad-0.59471500$

$\mathrm{H} \quad-4.40635000 \quad 0.46540700 \quad-1.92032700$

$\mathrm{H} \quad-\quad-5.85773000 \quad-0.35529500 \quad-1.35489500$

$\mathrm{H} \quad-2.92351100 \quad-2.30722000 \quad 0.05108600$

$\mathrm{H} \quad-4.27879700 \quad-2.38205200 \quad-1.09141600$

$\mathrm{H} \quad-\quad-2.83795300 \quad-1.40058700 \quad-1.46728600$

$\mathrm{H} \quad-\quad-5.87329200 \quad-1.62500600 \quad 0.75809400$

$\mathrm{H} \quad-\quad-4.51766300 \quad-1.54588500 \quad 1.89326600$

$\begin{array}{llll}\mathrm{H} & -5.54358600 & -0.11515600 & 1.63472000\end{array}$

$\begin{array}{llll}\mathrm{C} & 3.16934700 & -2.79780400 & 2.26519700\end{array}$

$\begin{array}{llll}\text { C } & 3.10285200 & -1.45203100 & 2.64281700\end{array}$

$\begin{array}{llll}\mathrm{C} & 2.98854400 & -0.45040400 & 1.68605400\end{array}$

$\begin{array}{llll}\mathrm{C} & 2.96587100 & -0.75369800 & 0.30232100\end{array}$

$\begin{array}{llll}\mathrm{C} & 3.03834200 & -2.12033500 & -0.06020400\end{array}$

$\begin{array}{llll}\mathrm{C} & 3.12931000 & -3.11733500 & 0.90312700\end{array}$

$\mathrm{H} \quad 3.25026000 \quad-3.57848500 \quad 3.01522000$

$\mathrm{H} \quad 3.11491400 \quad-1.18063300 \quad 3.69511400$

$\mathrm{H} \quad 2.89779000 \quad 0.57007200 \quad 2.03803300$

$\mathrm{H} \quad 2.98918600 \quad-2.37117300 \quad-1.11418800$

$\mathrm{H} \quad 3.16159200 \quad-4.15796500 \quad 0.58967900$

$\begin{array}{llll}\mathrm{C} & 2.83845900 & 0.22276500 & -0.79799400\end{array}$

$\begin{array}{llll}\mathrm{C} & 2.64539800 & 1.67569400 & -0.54236800\end{array}$ 


$\begin{array}{lrrr}\mathrm{C} & 3.30126700 & 2.41416400 & 0.46651300 \\ \mathrm{C} & 1.78955400 & 2.37505400 & -1.41902300 \\ \mathrm{C} & 3.05268000 & 3.77460200 & 0.63446500 \\ \mathrm{H} & 4.04192200 & 1.93545500 & 1.09773800 \\ \mathrm{C} & 1.53549900 & 3.73295900 & -1.24081900 \\ \mathrm{H} & 1.30154100 & 1.81714200 & -2.20891500 \\ \mathrm{C} & 2.15176300 & 4.44145400 & -0.20409400 \\ \mathrm{H} & 3.57739200 & 4.32109100 & 1.41255400 \\ \mathrm{H} & 0.85278400 & 4.24369700 & -1.91486500 \\ \mathrm{H} & 1.95604900 & 5.50020000 & -0.06701800 \\ \mathrm{O} & 2.88215200 & -0.15624000 & -1.98904300 \\ \mathrm{~K} & -2.70145800 & 2.54503200 & -1.26602500 \\ \mathrm{~K} & 0.25361200 & 2.03240300 & 1.21810700\end{array}$


Single Point Triplet, Using Singlet Complex (of $\mathbf{4 6}$ and

17, counterions) Optimised Geometry

63

$-2585.0749126$

\begin{tabular}{|c|c|c|c|}
\hline $\mathrm{C}$ & 0.84795900 & -3.29825300 & -3.26774500 \\
\hline $\mathrm{C}$ & 0.53231300 & -3.64211700 & -1.94275600 \\
\hline $\mathrm{C}$ & 0.11927600 & -2.68372500 & -1.03084300 \\
\hline $\mathrm{C}$ & -0.00776500 & -1.30897600 & -1.39430500 \\
\hline $\mathrm{C}$ & 0.32516300 & -0.98573300 & -2.74259900 \\
\hline $\mathrm{C}$ & 0.72775200 & -1.95809900 & -3.64906200 \\
\hline $\mathrm{H}$ & 1.16959900 & -4.05471600 & -3.97717700 \\
\hline $\mathrm{H}$ & 0.60425900 & -4.67898600 & -1.62069300 \\
\hline $\mathrm{H}$ & -0.15424200 & -3.00602300 & -0.03094700 \\
\hline $\mathrm{H}$ & 0.22719500 & 0.04712500 & -3.05826500 \\
\hline $\mathrm{H}$ & 0.96615300 & -1.66527300 & -4.66968300 \\
\hline $\mathrm{C}$ & -0.54563700 & -0.28369100 & -0.54555900 \\
\hline $\mathrm{C}$ & -0.98688900 & -0.57553800 & 0.82709100 \\
\hline $\mathrm{C}$ & -0.16853800 & -1.24201200 & 1.77087800 \\
\hline $\mathrm{C}$ & -2.21947800 & -0.05441700 & 1.33195900 \\
\hline $\mathrm{C}$ & -0.47472000 & -1.27824100 & 3.12826300 \\
\hline $\mathrm{H}$ & 0.76111100 & -1.67785400 & 1.42422300 \\
\hline $\mathrm{C}$ & -2.49964300 & -0.05477600 & 2.69481700 \\
\hline $\mathrm{C}$ & -1.62647700 & -0.65061100 & 3.61227400 \\
\hline $\mathrm{H}$ & 0.21376800 & -1.76853400 & 3.81188300 \\
\hline $\mathrm{H}$ & -3.43550500 & 0.38649800 & 3.02764800 \\
\hline $\mathrm{H}$ & -1.85587200 & -0.64080600 & 4.67279800 \\
\hline $\mathrm{O}$ & -0.84456000 & 0.90260600 & -1.02369300 \\
\hline $\mathrm{O}$ & -3.19201100 & 0.43687900 & 0.46729900 \\
\hline $\mathrm{C}$ & -4.18303800 & -0.52993500 & -0.00412500 \\
\hline $\mathrm{C}$ & -5.00347800 & 0.24401300 & -1.02947400 \\
\hline $\mathrm{C}$ & -3.50988300 & -1.72790700 & -0.66849900 \\
\hline $\mathrm{C}$ & -5.08052700 & -0.97928000 & 1.14740400 \\
\hline $\mathrm{H}$ & -5.38824400 & 1.17301500 & -0.59471500 \\
\hline $\mathrm{H}$ & -4.40635000 & 0.46540700 & -1.92032700 \\
\hline $\mathrm{H}$ & -5.85773000 & -0.35529500 & -1.35489500 \\
\hline $\mathrm{H}$ & -2.92351100 & -2.30722000 & 0.05108600 \\
\hline $\mathrm{H}$ & -4.27879700 & -2.38205200 & -1.09141600 \\
\hline $\mathrm{H}$ & -2.83795300 & -1.40058700 & -1.46728600 \\
\hline $\mathrm{H}$ & -5.87329200 & -1.62500600 & 0.75809400 \\
\hline $\mathrm{H}$ & -4.51766300 & -1.54588500 & 1.89326600 \\
\hline $\mathrm{H}$ & -5.54358600 & -0.11515600 & 1.63472000 \\
\hline $\mathrm{C}$ & 3.16934700 & -2.79780400 & 2.26519700 \\
\hline $\mathrm{C}$ & 3.10285200 & -1.45203100 & 2.64281700 \\
\hline $\mathrm{C}$ & 2.98854400 & -0.45040400 & 1.68605400 \\
\hline $\mathrm{C}$ & 2.96587100 & -0.75369800 & 0.30232100 \\
\hline $\mathrm{C}$ & 3.03834200 & -2.12033500 & -0.06020400 \\
\hline $\mathrm{C}$ & 3.12931000 & -3.11733500 & 0.90312700 \\
\hline $\mathrm{H}$ & 3.25026000 & -3.57848500 & 3.01522000 \\
\hline $\mathrm{H}$ & 3.11491400 & -1.18063300 & 3.69511400 \\
\hline $\mathrm{H}$ & 2.89779000 & 0.57007200 & 2.03803300 \\
\hline $\mathrm{H}$ & 2.98918600 & -2.37117300 & -1.11418800 \\
\hline $\mathrm{H}$ & 3.16159200 & -4.15796500 & 0.58967900 \\
\hline $\mathrm{C}$ & 2.83845900 & 0.22276500 & -0.79799400 \\
\hline $\mathrm{C}$ & 2.64539800 & 1.67569400 & -0.54236800 \\
\hline $\mathrm{C}$ & 3.30126700 & 2.41416400 & 0.46651300 \\
\hline $\mathrm{C}$ & 1.78955400 & 2.37505400 & -1.41902300 \\
\hline $\mathrm{C}$ & 3.05268000 & 3.77460200 & 0.63446500 \\
\hline $\mathrm{H}$ & 4.04192200 & 1.93545500 & 1.09773800 \\
\hline $\mathrm{C}$ & 1.53549900 & 3.73295900 & -1.24081900 \\
\hline $\mathrm{H}$ & 1.30154100 & 1.81714200 & -2.20891500 \\
\hline $\mathrm{C}$ & 2.15176300 & 4.44145400 & -0.20409400 \\
\hline $\mathrm{H}$ & 3.57739200 & 4.32109100 & 1.41255400 \\
\hline $\mathrm{H}$ & 0.85278400 & 4.24369700 & -1.91486500 \\
\hline $\mathrm{H}$ & 1.95604900 & 5.50020000 & -0.06701800 \\
\hline
\end{tabular}


O $\quad 2.88215200 \quad-0.15624000 \quad-1.98904300$

$\begin{array}{llll}\mathrm{K} & -2.70145800 & 2.54503200 & -1.26602500\end{array}$

$\begin{array}{llll}\mathrm{K} & 0.25361200 & 2.03240300 & 1.21810700\end{array}$ 
Triplet Complex between 46 and 17 (counterions)

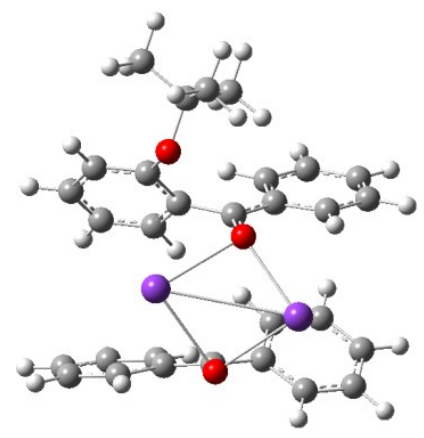

63

$-2585.1100546$

$\begin{array}{llll}\text { C } & -0.00789200 & 4.27420500 & -2.22961300\end{array}$

$\begin{array}{llll}\text { C } & -0.47176300 & 3.11282900 & -2.86804400\end{array}$

$\begin{array}{llll}\mathrm{C} & -0.78548100 & 1.97159500 & -2.14556000\end{array}$

$\begin{array}{lllll}\text { C } & -0.62693800 & 1.92397100 & -0.72995600\end{array}$

$\begin{array}{llll}\text { C } & -0.18540000 & 3.12361700 & -0.10134000\end{array}$

$\begin{array}{llll}\mathrm{C} & 0.11424600 & 4.26231900 & -0.83471300\end{array}$

$\mathrm{H} \quad 0.23528200 \quad 5.16331100 \quad-2.80221100$

$\mathrm{H} \quad-0.59710400 \quad 3.10501400 \quad-3.94806900$

$\mathrm{H} \quad-1.16137300 \quad 1.10048800 \quad-2.67455400$

$\begin{array}{llll}\mathrm{H} & -0.10962900 & 3.14464000 & 0.98085800\end{array}$

$\begin{array}{llll}\mathrm{H} & 0.44939300 & 5.15675600 & -0.31433600\end{array}$

$\begin{array}{lllll}\mathrm{C} & -0.92076400 & 0.77163700 & 0.07370600\end{array}$

$\begin{array}{llll}\text { C } & -1.48707200 & -0.47045300 & -0.53914300\end{array}$

$\begin{array}{lllll}\text { C } & & -0.77228900 & -1.19743500 & -1.50802300\end{array}$

$\begin{array}{lllll}\text { C } & -2.69427300 & -1.03677300 & -0.07018400\end{array}$

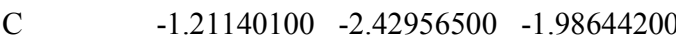

$\mathrm{H} \quad \begin{array}{llll}\mathrm{H} & 0.17403500 & -0.80086200 & -1.86441600\end{array}$

C $\quad-3.12466100 \quad-2.28436800 \quad-0.53209900$

C $\quad-2.39211200 \quad-2.98252000 \quad-1.48975500$

$\mathrm{H} \quad-0.61287700 \quad-2.96710900-2.71591300$

$\mathrm{H} \quad-4.04065000 \quad-2.69889900 \quad-0.12249200$

$\mathrm{H} \quad-2.73678800 \quad-3.95183100 \quad-1.83590400$

$\begin{array}{llll}\mathrm{O} & -0.72149500 & 0.76699900 & 1.35523900\end{array}$

$\begin{array}{lllll}\mathrm{O} & -3.41730900 & -0.42351200 & 0.92619800\end{array}$

$\begin{array}{lllll}\mathrm{C} & -4.52085800 & 0.45417500 & 0.56212000\end{array}$

$\begin{array}{lllll}\mathrm{C} & & -5.03655400 & 0.94439600 & 1.90884200\end{array}$

$\begin{array}{llll}\text { C } & -4.02540900 & 1.62338800 & -0.28330800\end{array}$

$\begin{array}{lllll}\mathrm{C} & & -5.60623800 & -0.32487400 & -0.17791900\end{array}$

$\begin{array}{llll}\mathrm{H} & -5.37672100 & 0.09989900 & 2.51558000\end{array}$

$\begin{array}{lllll}\mathrm{H} & -4.23999700 & 1.46642300 & 2.44680200\end{array}$

$\mathrm{H} \quad-5.87392700 \quad 1.63306000 \quad 1.76536600$

$\mathrm{H} \quad-3.57859000 \quad 1.27665800 \quad-1.22107700$

$\mathrm{H} \quad-4.86918800 \quad 2.27623100 \quad-0.52795500$

$\mathrm{H} \quad-3.27235700 \quad 2.20223000 \quad 0.25870200$

$\mathrm{H} \quad-6.46930600 \quad 0.32604600 \quad-0.34659300$

$\mathrm{H} \quad-\quad-5.25277500 \quad-0.67675200 \quad-1.15142000$

$\begin{array}{llll}\mathrm{H} & -5.93200800 & -1.18661700 & 0.41302000\end{array}$

$\begin{array}{llll}\mathrm{C} & 3.87552600 & 2.95228000 & -0.53037400\end{array}$

$\begin{array}{llll}\mathrm{C} & 2.97627800 & 2.22818400 & -1.31470000\end{array}$

$\begin{array}{llll}\text { C } & 2.54826300 & 0.96581800 & -0.91544200\end{array}$

$\begin{array}{llll}\mathrm{C} & 2.99773900 & 0.38586400 & 0.28520100\end{array}$

$\begin{array}{llll}\text { C } & 3.89315200 & 1.13945700 & 1.07325900\end{array}$

$\begin{array}{llll}\mathrm{C} & 4.32998200 & 2.39922700 & 0.66964400\end{array}$

$\mathrm{H} \quad 4.20395700 \quad 3.93957100 \quad-0.84021700$

$\mathrm{H} \quad 2.56917700 \quad 2.66229800 \quad-2.22398700$

$\mathrm{H} \quad \begin{array}{llll}\mathrm{H} & 1.80314500 & 0.45493500 & -1.51460600\end{array}$

$\mathrm{H} \quad 4.24950100 \quad 0.71096100 \quad 2.00709500$

$\begin{array}{llll}\mathrm{H} & 5.02966300 & 2.95054900 & 1.29187100\end{array}$

$\begin{array}{lllll}\mathrm{C} & 2.51863400 & -0.91761600 & 0.81032900\end{array}$

$\begin{array}{llll}\mathrm{C} & 2.41340700 & -2.09702700 & -0.02462300\end{array}$

$\begin{array}{llll}\text { C } & 2.69141400 & -2.13652100 & -1.42175200\end{array}$ 
$\begin{array}{llll}\mathrm{C} & 2.06698200 & -3.34034400 & 0.58085100\end{array}$

$\begin{array}{llll}\mathrm{C} & 2.54477000 & -3.30314000 & -2.15525400\end{array}$

$\mathrm{H} \quad 3.04108100 \quad-1.24534000 \quad-1.93045400$

$\begin{array}{llll}\mathrm{C} & 1.92364400 & -4.50352600 & -0.16586800\end{array}$

$\begin{array}{llll}\mathrm{H} & 1.96273900 & -3.37889800 & 1.66148900\end{array}$

$\begin{array}{llll}\mathrm{C} & 2.13764800 & -4.50056600 & -1.54746300\end{array}$

$\mathrm{H} \quad 2.76046000 \quad-3.28549700 \quad-3.22059400$

$\mathrm{H} \quad \begin{array}{llll}\mathrm{H} & 1.65652500 & -5.42877700 & 0.33877100\end{array}$

$\mathrm{H} \quad 2.02018500 \quad-5.40784200 \quad-2.13101800$

$\begin{array}{llll}\mathrm{O} & 2.28697900 & -0.99744700 & 2.08591200\end{array}$

$\begin{array}{llll}\mathrm{K} & 1.33593900 & 1.43415900 & 2.77617500\end{array}$

$\begin{array}{llll}\mathrm{K} & -0.29345100 & -1.82670600 & 1.87715200\end{array}$ 
Single Point Singlet, Using Triplet Complex (of $\mathbf{4 6}$ and

17, counterions) Optimised Geometry

63

$-2585.0741665$

\begin{tabular}{|c|c|c|c|}
\hline $\mathrm{C}$ & 0.00789200 & -4.27420500 & 1300 \\
\hline $\mathrm{C}$ & 0.47176300 & -3.11282900 & -2.86804400 \\
\hline $\mathrm{C}$ & 0.78548100 & -1.97159500 & -2.14556000 \\
\hline $\mathrm{C}$ & 0.62693800 & -1.92397100 & -0.72995600 \\
\hline $\mathrm{C}$ & 0.18540000 & -3.12361700 & -0.10134000 \\
\hline $\mathrm{C}$ & -0.11424600 & -4.26231900 & -0.83471300 \\
\hline $\mathrm{H}$ & -0.23528200 & -5.16331100 & -2.80221100 \\
\hline $\mathrm{H}$ & 0.59710400 & -3.10501400 & -3.94806900 \\
\hline $\mathrm{H}$ & 1.16137300 & -1.10048800 & -2.67455400 \\
\hline $\mathrm{H}$ & 0.10962900 & -3.14464000 & 0.98085800 \\
\hline $\mathrm{H}$ & -0.44939300 & -5.15675600 & -0.31433600 \\
\hline $\mathrm{C}$ & 0.92076400 & -0.77163700 & 0.07370600 \\
\hline $\mathrm{C}$ & 1.48707200 & 0.47045300 & -0.53914300 \\
\hline $\mathrm{C}$ & 0.77228900 & 1.19743500 & -1.50802300 \\
\hline $\mathrm{C}$ & 2.69427300 & 1.03677300 & -0.07018400 \\
\hline $\mathrm{C}$ & 1.21140100 & 2.42956500 & -1.98644200 \\
\hline $\mathrm{H}$ & -0.17403500 & 0.80086200 & -1.86441600 \\
\hline $\mathrm{C}$ & 3.12466100 & 2.28436800 & -0.53209900 \\
\hline $\mathrm{C}$ & 2.39211200 & 2.98252000 & -1.48975500 \\
\hline $\mathrm{H}$ & 0.61287700 & 2.96710900 & -2.71591300 \\
\hline $\mathrm{H}$ & 4.04065000 & 2.69889900 & -0.12249200 \\
\hline $\mathrm{H}$ & 2.73678800 & 3.95183100 & -1.83590400 \\
\hline $\mathrm{O}$ & 0.72149500 & -0.76699900 & 1.35523900 \\
\hline $\mathrm{O}$ & 3.41730900 & 0.42351200 & 0.92619800 \\
\hline $\mathrm{C}$ & 4.52085800 & -0.45417500 & 0.56212000 \\
\hline $\mathrm{C}$ & 5.03655400 & -0.94439600 & 1.90884200 \\
\hline $\mathrm{C}$ & 4.02540900 & -1.62338800 & -0.28330800 \\
\hline $\mathrm{C}$ & 5.60623800 & 0.32487400 & -0.17791900 \\
\hline $\mathrm{H}$ & 5.37672100 & -0.09989900 & 2.51558000 \\
\hline $\mathrm{H}$ & 4.23999700 & -1.46642300 & 2.44680200 \\
\hline $\mathrm{H}$ & 5.87392700 & -1.63306000 & 1.76536600 \\
\hline $\mathrm{H}$ & 3.57859000 & -1.27665800 & -1.22107700 \\
\hline $\mathrm{H}$ & 4.86918800 & -2.27623100 & -0.52795500 \\
\hline $\mathrm{H}$ & 3.27235700 & -2.20223000 & 0.25870200 \\
\hline $\mathrm{H}$ & 6.46930600 & -0.32604600 & -0.34659300 \\
\hline $\mathrm{H}$ & 5.25277500 & 0.67675200 & -1.15142000 \\
\hline $\mathrm{H}$ & 5.93200800 & 1.18661700 & 0.41302000 \\
\hline $\mathrm{C}$ & -3.87552600 & -2.95228000 & -0.53037400 \\
\hline $\mathrm{C}$ & -2.97627800 & -2.22818400 & -1.31470000 \\
\hline $\mathrm{C}$ & -2.54826300 & -0.96581800 & -0.91544200 \\
\hline $\mathrm{C}$ & -2.99773900 & -0.38586400 & 0.28520100 \\
\hline $\mathrm{C}$ & -3.89315200 & -1.13945700 & 1.07325900 \\
\hline $\mathrm{C}$ & -4.32998200 & -2.39922700 & 0.66964400 \\
\hline $\mathrm{H}$ & -4.20395700 & -3.93957100 & -0.84021700 \\
\hline $\mathrm{H}$ & -2.56917700 & -2.66229800 & -2.22398700 \\
\hline $\mathrm{H}$ & -1.80314500 & -0.45493500 & -1.51460600 \\
\hline $\mathrm{H}$ & -4.24950100 & -0.71096100 & 2.00709500 \\
\hline $\mathrm{H}$ & -5.02966300 & -2.95054900 & 1.29187100 \\
\hline $\mathrm{C}$ & -2.51863400 & 0.91761600 & 0.81032900 \\
\hline $\mathrm{C}$ & -2.41340700 & 2.09702700 & -0.02462300 \\
\hline $\mathrm{C}$ & -2.69141400 & 2.13652100 & -1.42175200 \\
\hline $\mathrm{C}$ & -2.06698200 & 3.34034400 & 0.58085100 \\
\hline $\mathrm{C}$ & -2.54477000 & 3.30314000 & -2.15525400 \\
\hline $\mathrm{H}$ & -3.04108100 & 1.24534000 & -1.93045400 \\
\hline $\mathrm{C}$ & -1.92364400 & 4.50352600 & -0.16586800 \\
\hline $\mathrm{H}$ & -1.96273900 & 3.37889800 & 1.66148900 \\
\hline $\mathrm{C}$ & -2.13764800 & 4.50056600 & -1.54746300 \\
\hline $\mathrm{H}$ & -2.76046000 & 3.28549700 & -3.22059400 \\
\hline $\mathrm{H}$ & -1.65652500 & 5.42877700 & 0.33877100 \\
\hline $\mathrm{H}$ & -2.02018500 & 5.40784200 & -2.1310180 \\
\hline
\end{tabular}




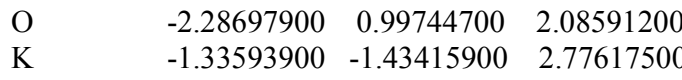

$\begin{array}{llll}\mathrm{K} & 0.29345100 & 1.82670600 & 1.87715200\end{array}$ 
Singlet Complex between $\mathbf{2 4}$ and $\mathbf{1 7}$ (no counterions)

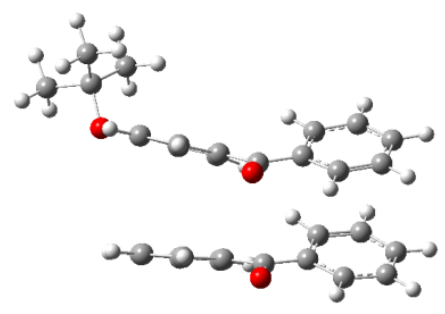

61

$-1385.3732444$

C -5.10017

C -3.76676

C $\quad-2.73692$

C $\quad-2.98117$

C $\quad-4.33016$

C $\quad-5.36184$

$\mathrm{H} \quad-5.90346$

$\mathrm{H} \quad-3.52580$

$\mathrm{H} \quad-1.71899$

$\mathrm{H} \quad-4.53687$

$\mathrm{H} \quad-6.38324$

C $\quad-1.96905$

$\begin{array}{ll}0.10807 & -1.78301 \\ 0.02184 & -2.21120\end{array}$

$\begin{array}{ll}0.02184 & -2.21120\end{array}$

$\begin{array}{ll}0.57166 & -1.46555\end{array}$

$\begin{array}{ll}1.25385 & -0.24409\end{array}$

$\begin{array}{ll}1.27894 & 0.19597\end{array}$

$\begin{array}{ll}0.73713 & -0.56205\end{array}$

$-0.32088-2.37523$

$\begin{array}{ll}-0.52089 & -3.12278 \\ 0.41086 & -1.80230\end{array}$

$\begin{array}{ll}0.41086 & -1.80230\end{array}$

$\begin{array}{ll}1.75243 & 1.15040\end{array}$

$\begin{array}{ll}0.79465 & -0.19061\end{array}$

$\begin{array}{lll}-1.96905 & 1.85084 & 0.63146\end{array}$

$\begin{array}{llll}\mathrm{C} & -0.64410 & 2.26220 & 0.14329\end{array}$

$\begin{array}{llll}\text { C } & -0.28313 & 2.45291 & -1.21365\end{array}$

$\begin{array}{llll}\text { C } & 0.33815 & 2.61285 & 1.10695\end{array}$

$\begin{array}{llll}\mathrm{C} & 0.97589 & 2.92314 & -1.57549\end{array}$

$\begin{array}{llll}\mathrm{H} & -1.01203 & 2.28629 & -1.99862\end{array}$

$\begin{array}{llll}\mathrm{C} & 1.59841 & 3.06167 & 0.73998\end{array}$

$\begin{array}{llll}\mathrm{H} & 0.07742 & 2.50569 & 2.15480\end{array}$

$\begin{array}{llll}\mathrm{C} & 1.94118 & 3.22136 & -0.60815\end{array}$

$\begin{array}{llll}\mathrm{H} & 1.20241 & 3.06709 & -2.62992\end{array}$

$\begin{array}{llll}\mathrm{H} & 2.33019 & 3.28548 & 1.51370\end{array}$

$\begin{array}{llll}\mathrm{H} & 2.92740 & 3.57442 & -0.89550\end{array}$

$\begin{array}{llll}\mathrm{O} & -2.29962 & 2.16431 & 1.82861\end{array}$

$\begin{array}{llll}\text { C } & -3.90161 & -3.09579 & -0.56226\end{array}$

$\begin{array}{llll}\text { C } & -2.60549 & -3.07430 & -1.08985\end{array}$

$\begin{array}{llll}\text { C } & -1.58218 & -2.37755 & -0.45570\end{array}$

$\begin{array}{llll}\text { C } & -1.80414 & -1.67092 & 0.75355\end{array}$

$\begin{array}{llll}\text { C } & -3.11929 & -1.73718 & 1.28822\end{array}$

$\begin{array}{llll}\text { C } & -4.13827 & -2.41630 & 0.63972\end{array}$

$\begin{array}{llll}\mathrm{H} & -4.69982 & -3.63426 & -1.06498\end{array}$

$\mathrm{H} \quad-2.38472 \quad-3.61527 \quad-2.00771$

$\begin{array}{llll}\mathrm{H} & -0.58568 & -2.43308 & -0.87966\end{array}$

$\begin{array}{llll}\mathrm{H} & -3.30901 & -1.22314 & 2.22497\end{array}$

$\begin{array}{llll}\mathrm{H} & -5.13775 & -2.41244 & 1.07023\end{array}$

$\begin{array}{llll}\text { C } & -0.77718 & -0.99086 & 1.54770\end{array}$

$\begin{array}{llll}\text { C } & 0.57383 & -0.72137 & 1.01895\end{array}$

$\begin{array}{llll}\text { C } & 0.89696 & -0.52239 & -0.34298\end{array}$

$\begin{array}{llll}\text { C } & 1.62604 & -0.55506 & 1.94589\end{array}$

$\begin{array}{llll}\mathrm{C} & 2.19377 & -0.25619 & -0.75409\end{array}$

$\begin{array}{llll}\mathrm{H} & 0.10644 & -0.50421 & -1.08494\end{array}$

$\begin{array}{llll}\mathrm{C} & 2.93156 & -0.29645 & 1.53748\end{array}$

$\begin{array}{llll}\mathrm{H} & 1.39098 & -0.64142 & 3.00193\end{array}$

$\begin{array}{llll}\text { C } & 3.23064 & -0.16716 & 0.18172\end{array}$

$\begin{array}{llll}\mathrm{H} & 2.41038 & -0.06828 & -1.80251\end{array}$

$\begin{array}{llll}\mathrm{H} & 3.72869 & -0.18154 & 2.26794\end{array}$

$\begin{array}{llll}\mathrm{O} & -0.99641 & -0.77195 & 2.78427\end{array}$

$\begin{array}{llll}\mathrm{O} & 4.51887 & 0.14295 & -0.22581\end{array}$

$\begin{array}{llll}\mathrm{C} & 5.41036 & -0.95125 & -0.55668\end{array}$

$\begin{array}{llll}\text { C } & 6.71110 & -0.25486 & -0.93742\end{array}$

$\begin{array}{llll}\text { C } & 5.62259 & -1.85762 & 0.65446\end{array}$

$\begin{array}{llll}\text { C } & 4.86605 & -1.75178 & -1.73842\end{array}$

$\begin{array}{llll}\mathrm{H} & 6.54752 & 0.41004 & -1.79080\end{array}$

$\begin{array}{llll}\mathrm{H} & 7.08034 & 0.33965 & -0.09642\end{array}$

$\begin{array}{llll}\mathrm{H} & 7.47270 & -0.99227 & -1.20752\end{array}$ 


$\begin{array}{llll}\mathrm{H} & 4.69266 & -2.35546 & 0.94392 \\ \mathrm{H} & 6.36369 & -2.62667 & 0.41511 \\ \mathrm{H} & 5.98640 & -1.27568 & 1.50731 \\ \mathrm{H} & 5.59255 & -2.51558 & -2.03318 \\ \mathrm{H} & 3.92875 & -2.25181 & -1.47912 \\ \mathrm{H} & 4.68559 & -1.09284 & -2.59372\end{array}$


Single Point Triplet, Using

Singlet Complex (of $\mathbf{2 4}$ and

17 , no counterions)

Optimised Geometry

61

$-1385.3745736$

\begin{tabular}{|c|c|c|c|}
\hline C & -5.10016900 & 0.10807000 & 00600 \\
\hline $\mathrm{C}$ & -3.76676100 & 0.02184000 & -2.21120200 \\
\hline $\mathrm{C}$ & -2.73691900 & 0.57166000 & -1.46554700 \\
\hline $\mathrm{C}$ & -2.98116900 & 1.25384800 & -0.24408700 \\
\hline $\mathrm{C}$ & -4.33016200 & 1.27893900 & 0.19597200 \\
\hline $\mathrm{C}$ & -5.36183500 & 0.73712800 & -0.56204600 \\
\hline $\mathrm{H}$ & -5.90346300 & -0.32088200 & -2.37522800 \\
\hline $\mathrm{H}$ & -3.52579900 & -0.52089200 & -3.12278300 \\
\hline $\mathrm{H}$ & -1.71898600 & 0.41086400 & -1.80230200 \\
\hline $\mathrm{H}$ & -4.53687400 & 1.75243200 & 1.15039700 \\
\hline $\mathrm{H}$ & -6.38323800 & 0.79464800 & -0.19061300 \\
\hline $\mathrm{C}$ & -1.96905300 & 1.85083600 & 0.63146300 \\
\hline $\mathrm{C}$ & -0.64409600 & 2.26219800 & 0.14329100 \\
\hline $\mathrm{C}$ & -0.28312700 & 2.45290600 & -1.21364600 \\
\hline $\mathrm{C}$ & 0.33815300 & 2.61285400 & 1.10695300 \\
\hline $\mathrm{C}$ & 0.97589500 & 2.92314400 & -1.57549000 \\
\hline $\mathrm{H}$ & -1.01203300 & 2.28629400 & -1.99861500 \\
\hline $\mathrm{C}$ & 1.59841000 & 3.06166700 & 0.73997900 \\
\hline $\mathrm{H}$ & 0.07741700 & 2.50569000 & 2.15479900 \\
\hline $\mathrm{C}$ & 1.94117600 & 3.22136300 & -0.60815100 \\
\hline $\mathrm{H}$ & 1.20240600 & 3.06709200 & -2.62991500 \\
\hline $\mathrm{H}$ & 2.33018500 & 3.28548500 & 1.51369600 \\
\hline $\mathrm{H}$ & 2.92739700 & 3.57442400 & -0.89550200 \\
\hline $\mathrm{O}$ & -2.29962500 & 2.16431100 & 1.82861300 \\
\hline $\mathrm{C}$ & -3.90160600 & -3.09578900 & -0.56225800 \\
\hline $\mathrm{C}$ & -2.60548900 & -3.07429500 & -1.08984700 \\
\hline $\mathrm{C}$ & -1.58218300 & -2.37754700 & -0.45569800 \\
\hline $\mathrm{C}$ & -1.80413600 & -1.67091700 & 0.75355500 \\
\hline $\mathrm{C}$ & -3.11928900 & -1.73717900 & 1.28821800 \\
\hline $\mathrm{C}$ & -4.13826600 & -2.41629700 & 0.63972500 \\
\hline $\mathrm{H}$ & -4.69981900 & -3.63426100 & -1.06497600 \\
\hline $\mathrm{H}$ & -2.38472200 & -3.61526900 & -2.00770500 \\
\hline $\mathrm{H}$ & -0.58567900 & -2.43308300 & -0.87966200 \\
\hline $\mathrm{H}$ & -3.30901400 & -1.22313600 & 2.22497200 \\
\hline $\mathrm{H}$ & -5.13774800 & -2.41244400 & 1.07022800 \\
\hline $\mathrm{C}$ & -0.77717600 & -0.99086500 & 1.54770300 \\
\hline $\mathrm{C}$ & 0.57383100 & -0.72136800 & 1.01894900 \\
\hline $\mathrm{C}$ & 0.89696400 & -0.52239300 & -0.34297700 \\
\hline $\mathrm{C}$ & 1.62604300 & -0.55505700 & 1.94588500 \\
\hline $\mathrm{C}$ & 2.19377100 & -0.25618800 & -0.75409500 \\
\hline $\mathrm{H}$ & 0.10643600 & -0.50421300 & -1.08493700 \\
\hline $\mathrm{C}$ & 2.93156300 & -0.29645200 & 1.53748100 \\
\hline $\mathrm{H}$ & 1.39098500 & -0.64142000 & 3.00192700 \\
\hline $\mathrm{C}$ & 3.23064000 & -0.16715900 & 0.18171800 \\
\hline $\mathrm{H}$ & 2.41038400 & -0.06827600 & -1.80251200 \\
\hline $\mathrm{H}$ & 3.72868800 & -0.18154300 & 2.26794300 \\
\hline $\mathrm{O}$ & -0.99641100 & -0.77195300 & 2.78427000 \\
\hline $\mathrm{O}$ & 4.51886800 & 0.14294900 & -0.22581200 \\
\hline $\mathrm{C}$ & 5.41035600 & -0.95124500 & -0.55667900 \\
\hline $\mathrm{C}$ & 6.71109800 & -0.25485600 & -0.93742300 \\
\hline $\mathrm{C}$ & 5.62259100 & -1.85761900 & 0.65445900 \\
\hline $\mathrm{C}$ & 4.86605000 & -1.75178300 & -1.73842300 \\
\hline $\mathrm{H}$ & 6.54751600 & 0.41004400 & -1.79080000 \\
\hline $\mathrm{H}$ & 7.08034300 & 0.33965200 & -0.09642500 \\
\hline $\mathrm{H}$ & 7.47270300 & -0.99227200 & -1.20752200 \\
\hline $\mathrm{H}$ & 4.69266200 & -2.35546400 & 0.94391600 \\
\hline $\mathrm{H}$ & 6.36368800 & -2.62667300 & 0.41511200 \\
\hline $\mathrm{H}$ & 5.98640200 & -1.27568000 & 1.50730600 \\
\hline $\mathrm{H}$ & 5.59254500 & -2.51558200 & -2.03318000 \\
\hline $\mathrm{H}$ & 3.92874600 & -2.25181000 & -1.4791230 \\
\hline
\end{tabular}


Triplet Complex between $\mathbf{2 4}$ and $\mathbf{1 7}$ (no counterions)

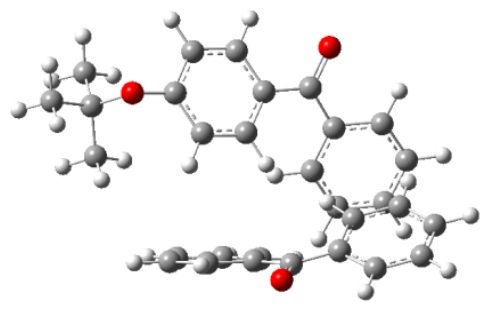

61

$-1385.3969055$

\begin{tabular}{|c|c|c|c|}
\hline & -5.18824500 & -0.51908900 & -1.54246600 \\
\hline 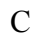 & -4.06327300 & 0.06402900 & -0.94806600 \\
\hline $\mathrm{C}$ & -2.96486300 & -0.71104200 & -0.59161900 \\
\hline $\mathrm{C}$ & -2.94200600 & -2.11075800 & -0.80562900 \\
\hline $\mathrm{C}$ & -4.07861300 & -2.67333100 & -1.43751500 \\
\hline $\mathrm{C}$ & -5.17712500 & -1.89676100 & -1.78860500 \\
\hline $\mathrm{H}$ & -6.04617200 & 0.08651400 & -1.81862800 \\
\hline $\mathrm{H}$ & -4.02590200 & 1.13550600 & -0.76201700 \\
\hline $\mathrm{H}$ & -2.10498400 & -0.20374200 & -0.16970800 \\
\hline $\mathrm{H}$ & -4.07005500 & -3.73958700 & -1.63950200 \\
\hline $\mathrm{H}$ & -6.03542900 & -2.36869700 & -2.26117900 \\
\hline $\mathrm{C}$ & -1.80497300 & -2.99490200 & -0.50637800 \\
\hline $\mathrm{C}$ & -0.78170800 & -2.65136000 & 0.48241000 \\
\hline $\mathrm{C}$ & -0.93801500 & -1.70815100 & 1.53194900 \\
\hline $\mathrm{C}$ & 0.43825100 & -3.38012200 & 0.46460000 \\
\hline $\mathrm{C}$ & 0.07292500 & -1.48052000 & 2.45830200 \\
\hline $\mathrm{H}$ & -1.87148900 & -1.16578300 & 1.64174400 \\
\hline $\mathrm{C}$ & 1.44197800 & -3.14854100 & 1.39538600 \\
\hline $\mathrm{H}$ & 0.56712500 & -4.12911900 & -0.30988100 \\
\hline $\mathrm{C}$ & 1.28123300 & -2.18590700 & 2.40003500 \\
\hline $\mathrm{H}$ & -0.08770600 & -0.74601500 & 3.24501300 \\
\hline $\mathrm{H}$ & 2.36593400 & -3.71982900 & 1.33745200 \\
\hline $\mathrm{H}$ & 2.07057700 & -1.99781200 & 3.12156600 \\
\hline $\mathrm{O}$ & -1.71610100 & -4.11542800 & -1.13051400 \\
\hline $\mathrm{C}$ & -3.64670400 & 2.36329500 & 2.21569500 \\
\hline $\mathrm{C}$ & -2.43072100 & 1.68621800 & 2.38093100 \\
\hline $\mathrm{C}$ & -1.37236400 & 1.88417400 & 1.50429300 \\
\hline $\mathrm{C}$ & -1.47981400 & 2.76876200 & 0.39583400 \\
\hline $\mathrm{C}$ & -2.70995300 & 3.47311600 & 0.27093900 \\
\hline $\mathrm{C}$ & -3.76254000 & 3.26841800 & 1.15283500 \\
\hline $\mathrm{H}$ & -4.47236100 & 2.19785300 & 2.90071200 \\
\hline $\mathrm{H}$ & -2.30271000 & 0.99827300 & 3.21447400 \\
\hline $\mathrm{H}$ & -0.43879200 & 1.36685600 & 1.69848000 \\
\hline $\mathrm{H}$ & -2.80768700 & 4.17830800 & -0.54804000 \\
\hline $\mathrm{H}$ & -4.69182700 & 3.81549400 & 1.00916000 \\
\hline $\mathrm{C}$ & -0.40755100 & 3.07059500 & -0.54713300 \\
\hline $\mathrm{C}$ & 0.78378700 & 2.21087800 & -0.68046100 \\
\hline $\mathrm{C}$ & 0.82183600 & 0.82805900 & -0.38847700 \\
\hline $\mathrm{C}$ & 1.96297900 & 2.77354900 & -1.22190300 \\
\hline $\mathrm{C}$ & 1.97271500 & 0.06945600 & -0.56993800 \\
\hline $\mathrm{H}$ & -0.06762500 & 0.31341900 & -0.04424300 \\
\hline $\mathrm{C}$ & 3.11819900 & 2.02057300 & -1.39985700 \\
\hline $\mathrm{H}$ & 1.94670700 & 3.82291900 & -1.49825400 \\
\hline $\mathrm{C}$ & 3.13957000 & 0.66598100 & -1.05621300 \\
\hline $\mathrm{H}$ & 1.95967700 & -0.99405300 & -0.34086500 \\
\hline $\mathrm{H}$ & 4.01798500 & 2.47295300 & -1.80916100 \\
\hline $\mathrm{O}$ & -0.48044700 & 4.13198500 & -1.26896900 \\
\hline $\mathrm{O}$ & 4.27575900 & -0.08917000 & -1.28713500 \\
\hline $\mathrm{C}$ & 5.21309700 & -0.26131100 & -0.19241000 \\
\hline $\mathrm{C}$ & 6.32828300 & -1.10129900 & -0.80256600 \\
\hline $\mathrm{C}$ & 5.75037600 & 1.09295200 & 0.26696400 \\
\hline $\mathrm{C}$ & 4.55534700 & -1.00388800 & 0.96817900 \\
\hline & 5.93079600 & -2.05784400 & -1.1545520 \\
\hline
\end{tabular}


H $\quad \begin{array}{llll}6.77742800 & -0.57569800 & -1.65058900\end{array}$

$\mathrm{H} \quad 7.10634900 \quad-1.29660500 \quad-0.05892500$

$\begin{array}{llll}\mathrm{H} & 4.95601000 & 1.70797600 & 0.69990800\end{array}$

$\begin{array}{llll}\mathrm{H} & 6.52185500 & 0.94521000 & 1.02891600\end{array}$

$\mathrm{H} \quad \begin{array}{llll}\mathrm{H} & 6.19184300 & 1.63405000 & -0.57606800\end{array}$

$\begin{array}{llll}\mathrm{H} & 5.30007200 & -1.20540200 & 1.74486200\end{array}$

$\begin{array}{llll}\mathrm{H} & 3.74623500 & -0.41663900 & 1.41183700\end{array}$

$\mathrm{H} \quad 4.13783100 \quad-1.95604400 \quad 0.62573800$ 
Single Point Singlet, Using

Triplet Complex (of $\mathbf{2 4}$ and

17 , no counterions)

Optimised Geometry

61

$-1385.3571770$

$\begin{array}{llll}\mathrm{C} & -5.18824500 & -0.51908900 & -1.54246600\end{array}$

$\begin{array}{lllll}\text { C } & -4.06327300 & 0.06402900 & -0.94806600\end{array}$

$\begin{array}{lllll}\mathrm{C} & -2.96486300 & -0.71104200 & -0.59161900\end{array}$

$\begin{array}{llll}\mathrm{C} & -2.94200600 & -2.11075800 & -0.80562900\end{array}$

C $\quad-\quad-4.07861300 \quad-2.67333100 \quad-1.43751500$

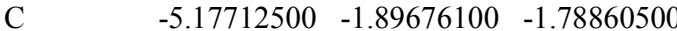

$\mathrm{H} \quad \begin{array}{llll}\mathrm{H} & -6.04617200 & 0.08651400 & -1.81862800\end{array}$

$\mathrm{H} \quad-4.02590200 \quad 1.13550600 \quad-0.76201700$

$\mathrm{H} \quad-2.10498400 \quad-0.20374200 \quad-0.16970800$

$\mathrm{H} \quad-4.07005500 \quad-3.73958700 \quad-1.63950200$

$\mathrm{H} \quad-6.03542900 \quad-2.36869700 \quad-2.26117900$

$\begin{array}{llll}\text { C } & -1.80497300 & -2.99490200 & -0.50637800\end{array}$

$\begin{array}{lllll}\mathrm{C} & & -0.78170800 & -2.65136000 & 0.48241000\end{array}$

$\begin{array}{llll}\text { C } & -0.93801500 & -1.70815100 & 1.53194900\end{array}$

$\begin{array}{llll}\text { C } & 0.43825100 & -3.38012200 & 0.46460000\end{array}$

$\begin{array}{llll}\mathrm{C} & 0.07292500 & -1.48052000 & 2.45830200\end{array}$

$\begin{array}{lllll}\mathrm{H} & & -1.87148900 & -1.16578300 & 1.64174400\end{array}$

$\begin{array}{llll}\mathrm{C} & 1.44197800 & -3.14854100 & 1.39538600\end{array}$

$\begin{array}{lllll}\mathrm{H} & 0.56712500 & -4.12911900 & -0.30988100\end{array}$

$\begin{array}{llll}\mathrm{C} & 1.28123300 & -2.18590700 & 2.40003500\end{array}$

$\mathrm{H} \quad-0.08770600 \quad-0.74601500 \quad 3.24501300$

$\mathrm{H} \quad 2.36593400 \quad-3.71982900 \quad 1.33745200$

$\mathrm{H} \quad 2.07057700 \quad-1.99781200 \quad 3.12156600$

O $\quad-1.71610100 \quad-4.11542800 \quad-1.13051400$

$\begin{array}{llll}\mathrm{C} & -3.64670400 & 2.36329500 & 2.21569500\end{array}$

$\begin{array}{llll}\text { C } & -2.43072100 & 1.68621800 & 2.38093100\end{array}$

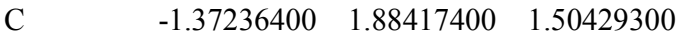

$\begin{array}{llll}\mathrm{C} & -1.47981400 & 2.76876200 & 0.39583400\end{array}$

$\begin{array}{llll}\text { C } & -2.70995300 & 3.47311600 & 0.27093900\end{array}$

$\begin{array}{llll}\mathrm{C} & -3.76254000 & 3.26841800 & 1.15283500\end{array}$

$\begin{array}{llll}\mathrm{H} & -4.47236100 & 2.19785300 & 2.90071200\end{array}$

$\mathrm{H} \quad-2.30271000 \quad 0.99827300 \quad 3.21447400$

$\begin{array}{lllll}\mathrm{H} & -0.43879200 & 1.36685600 & 1.69848000\end{array}$

$\mathrm{H} \quad-2.80768700 \quad 4.17830800 \quad-0.54804000$

$\begin{array}{llll}\mathrm{H} & -4.69182700 & 3.81549400 & 1.00916000\end{array}$

$\begin{array}{llll}\mathrm{C} & -0.40755100 & 3.07059500 & -0.54713300\end{array}$

$\begin{array}{llll}\text { C } & 0.78378700 & 2.21087800 & -0.68046100\end{array}$

$\begin{array}{lllll}\mathrm{C} & 0.82183600 & 0.82805900 & -0.38847700\end{array}$

$\begin{array}{llll}\mathrm{C} & 1.96297900 & 2.77354900 & -1.22190300\end{array}$

$\begin{array}{llll}\mathrm{C} & 1.97271500 & 0.06945600 & -0.56993800\end{array}$

$\begin{array}{lllll}\mathrm{H} & -0.06762500 & 0.31341900 & -0.04424300\end{array}$

$\begin{array}{lllll}\mathrm{C} & 3.11819900 & 2.02057300 & -1.39985700\end{array}$

$\begin{array}{llll}\mathrm{H} & 1.94670700 & 3.82291900 & -1.49825400\end{array}$

C $\quad 3.13957000 \quad 0.66598100 \quad-1.05621300$

$\mathrm{H} \quad \begin{array}{llll}\mathrm{H} & 1.95967700 & -0.99405300 & -0.34086500\end{array}$

$\mathrm{H} \quad 4.01798500 \quad 2.47295300 \quad-1.80916100$

O $\quad-0.48044700 \quad 4.13198500 \quad-1.26896900$

O $\quad 4.27575900 \quad-0.08917000 \quad-1.28713500$

$\begin{array}{llll}\text { C } & 5.21309700 & -0.26131100 & -0.19241000\end{array}$

$\begin{array}{llll}\text { C } & 6.32828300 & -1.10129900 & -0.80256600\end{array}$

$\begin{array}{llll}\mathrm{C} & 5.75037600 & 1.09295200 & 0.26696400\end{array}$

$\begin{array}{llll}\mathrm{C} & 4.55534700 & -1.00388800 & 0.96817900\end{array}$

$\mathrm{H} \quad 5.93079600 \quad-2.05784400 \quad-1.15455200$

$\mathrm{H} \quad 6.77742800 \quad-0.57569800 \quad-1.65058900$

$\mathrm{H} \quad 7.10634900 \quad-1.29660500 \quad-0.05892500$

$\begin{array}{llll}\mathrm{H} & 4.95601000 & 1.70797600 & 0.69990800\end{array}$

$\begin{array}{llll}\mathrm{H} & 6.52185500 & 0.94521000 & 1.02891600\end{array}$

$\mathrm{H} \quad \begin{array}{llll}\mathrm{H} & 6.19184300 & 1.63405000 & -0.57606800\end{array}$

$\begin{array}{llll}\mathrm{H} & 5.30007200 & -1.20540200 & 1.74486200\end{array}$

$\begin{array}{lllll}\mathrm{H} & 3.74623500 & -0.41663900 & 1.41183700\end{array}$ 
Singlet Complex between $\mathbf{2 4}$

and 17 (counterions)

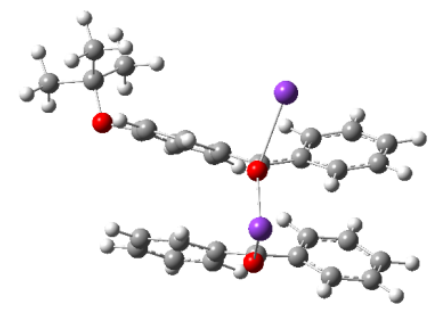

63

$-2585.0928644$

\begin{tabular}{|c|c|c|c|}
\hline $\mathrm{C}$ & -4.73708400 & 1.40014600 & -2.21282300 \\
\hline $\mathrm{C}$ & -3.39034100 & 1.39343500 & -2.59219900 \\
\hline $\mathrm{C}$ & -2.38698500 & 1.51316500 & -1.64156800 \\
\hline $\mathrm{C}$ & -2.69281300 & 1.64917600 & -0.27261000 \\
\hline $\mathrm{C}$ & -4.05103800 & 1.61541600 & 0.09634100 \\
\hline $\mathrm{C}$ & -5.05841400 & 1.50649100 & -0.85917300 \\
\hline $\mathrm{H}$ & -5.51901500 & 1.30872200 & -2.96091000 \\
\hline $\mathrm{H}$ & -3.12166600 & 1.26196800 & -3.63685500 \\
\hline $\mathrm{H}$ & -1.35175300 & 1.44189800 & -1.95786100 \\
\hline $\mathrm{H}$ & -4.29806000 & 1.69274600 & 1.15077600 \\
\hline $\mathrm{H}$ & -6.09902800 & 1.49874200 & -0.54522000 \\
\hline $\mathrm{C}$ & -1.68316700 & 1.75116300 & 0.80379600 \\
\hline $\mathrm{C}$ & -0.34491400 & 2.34876500 & 0.56987400 \\
\hline $\mathrm{C}$ & -0.02348800 & 3.17589200 & -0.52115500 \\
\hline $\mathrm{C}$ & 0.64245400 & 2.15361900 & 1.55528700 \\
\hline $\mathrm{C}$ & 1.23955800 & 3.75606700 & -0.63345500 \\
\hline $\mathrm{H}$ & -0.77246200 & 3.40447800 & -1.27165500 \\
\hline $\mathrm{C}$ & 1.90529200 & 2.71748000 & 1.43412700 \\
\hline $\mathrm{H}$ & 0.39629000 & 1.52449100 & 2.40393400 \\
\hline $\mathrm{C}$ & 2.21644900 & 3.52319700 & 0.33535000 \\
\hline $\mathrm{H}$ & 1.45730900 & 4.40013500 & -1.48110800 \\
\hline $\mathrm{H}$ & 2.65717500 & 2.52347400 & 2.19451400 \\
\hline $\mathrm{H}$ & 3.20323600 & 3.96663900 & 0.23908000 \\
\hline $\mathrm{O}$ & -2.03314700 & 1.51475700 & 1.99187000 \\
\hline $\mathrm{C}$ & -3.54913600 & -2.21212900 & -2.53144000 \\
\hline $\mathrm{C}$ & -2.22524300 & -1.93009200 & -2.89647100 \\
\hline $\mathrm{C}$ & -1.28912300 & -1.50001100 & -1.96583900 \\
\hline $\mathrm{C}$ & -1.61680700 & -1.32794200 & -0.58581300 \\
\hline $\mathrm{C}$ & -2.96540900 & -1.65989600 & -0.23804000 \\
\hline $\mathrm{C}$ & -3.89445500 & -2.07345800 & -1.18237700 \\
\hline $\mathrm{H}$ & -4.27643300 & -2.54140000 & -3.26690200 \\
\hline $\mathrm{H}$ & -1.91233200 & -2.05579400 & -3.93109300 \\
\hline $\mathrm{H}$ & -0.27314800 & -1.34150000 & -2.30782200 \\
\hline $\mathrm{H}$ & -3.25943700 & -1.56435000 & 0.80255200 \\
\hline $\mathrm{H}$ & -4.91277300 & -2.28731300 & -0.86227800 \\
\hline $\mathrm{C}$ & -0.70350700 & -0.97468700 & 0.47928700 \\
\hline $\mathrm{C}$ & 0.70747400 & -0.66421200 & 0.24783800 \\
\hline $\mathrm{C}$ & 1.22856600 & 0.00038100 & -0.89262300 \\
\hline $\mathrm{C}$ & 1.63924700 & -0.94267200 & 1.27686200 \\
\hline $\mathrm{C}$ & 2.57401600 & 0.31119200 & -1.01107600 \\
\hline $\mathrm{H}$ & 0.55442700 & 0.35550200 & -1.66401200 \\
\hline $\mathrm{C}$ & 2.99479300 & -0.64593400 & 1.15273500 \\
\hline $\mathrm{H}$ & 1.26461800 & -1.39009500 & 2.19208700 \\
\hline $\mathrm{C}$ & 3.47874100 & -0.02844100 & 0.00139500 \\
\hline $\mathrm{H}$ & 2.93376300 & 0.86212400 & -1.87642600 \\
\hline $\mathrm{H}$ & 3.68708800 & -0.87268500 & 1.96032600 \\
\hline $\mathrm{O}$ & -1.06086300 & -1.27052800 & 1.71778400 \\
\hline $\mathrm{O}$ & 4.80780500 & 0.34876800 & -0.09109300 \\
\hline $\mathrm{C}$ & 5.74151400 & -0.57455100 & -0.70839000 \\
\hline $\mathrm{C}$ & 7.07041900 & 0.16889500 & -0.65679900 \\
\hline $\mathrm{C}$ & 5.81904800 & -1.87057300 & 0.09595500 \\
\hline $\mathrm{C}$ & 5.34328300 & -0.86060600 & -2.15478500 \\
\hline $\mathrm{H}$ & 6.99915700 & 1.10863000 & -1.21249100 \\
\hline $\mathrm{H}$ & 7.33599800 & 0.39546100 & 0.38002200 \\
\hline $\mathrm{H}$ & 7.86524800 & -0.43944000 & -1.09775100 \\
\hline
\end{tabular}


H $\quad 4.86453300 \quad-2.40457300 \quad 0.07640300$

$\mathrm{H} \quad 6.58650700 \quad-2.52502400 \quad-0.32854400$

$\mathrm{H} \quad 6.07990700 \quad-1.65684300 \quad 1.13728500$

$\mathrm{H} \quad 6.10647000 \quad-1.48532300 \quad-2.62907800$

$\mathrm{H} \quad 4.38757000 \quad-1.39003900 \quad-2.20634100$

$\begin{array}{llll}\mathrm{H} & 5.25750500 & 0.07292700 & -2.71973400\end{array}$

K $\quad-\quad \begin{array}{llll}5.86901500 & -3.79725000 & 0.94225600\end{array}$

K $\quad-2.36701700 \quad-0.35660300 \quad 3.66392100$ 
Single Point Triplet, Using Singlet Complex (of $\mathbf{2 4}$ and

17, counterions) Optimised Geometry

63

$-2585.0809371$

\begin{tabular}{|c|c|c|c|}
\hline $\mathrm{C}$ & -4.73708400 & 1.40014600 & -2.2 \\
\hline $\mathrm{C}$ & -3.39034100 & 1.39343500 & -2.59219900 \\
\hline $\mathrm{C}$ & -2.38698500 & 1.51316500 & -1.64156800 \\
\hline $\mathrm{C}$ & -2.69281300 & 1.64917600 & -0.27261000 \\
\hline $\mathrm{C}$ & -4.05103800 & 1.61541600 & 0.09634100 \\
\hline $\mathrm{C}$ & -5.05841400 & 1.50649100 & -0.85917300 \\
\hline $\mathrm{H}$ & -5.51901500 & 1.30872200 & -2.96091000 \\
\hline $\mathrm{H}$ & -3.12166600 & 1.26196800 & -3.63685500 \\
\hline $\mathrm{H}$ & -1.35175300 & 1.44189800 & -1.95786100 \\
\hline $\mathrm{H}$ & -4.29806000 & 1.69274600 & 1.15077600 \\
\hline $\mathrm{H}$ & -6.09902800 & 1.49874200 & -0.54522000 \\
\hline $\mathrm{C}$ & -1.68316700 & 1.75116300 & 0.80379600 \\
\hline $\mathrm{C}$ & -0.34491400 & 2.34876500 & 0.56987400 \\
\hline $\mathrm{C}$ & -0.02348800 & 3.17589200 & -0.52115500 \\
\hline $\mathrm{C}$ & 0.64245400 & 2.15361900 & 1.55528700 \\
\hline $\mathrm{C}$ & 1.23955800 & 3.75606700 & -0.63345500 \\
\hline $\mathrm{H}$ & -0.77246200 & 3.40447800 & -1.27165500 \\
\hline $\mathrm{C}$ & 1.90529200 & 2.71748000 & 1.43412700 \\
\hline $\mathrm{H}$ & 0.39629000 & 1.52449100 & 2.40393400 \\
\hline $\mathrm{C}$ & 2.21644900 & 3.52319700 & 0.33535000 \\
\hline $\mathrm{H}$ & 1.45730900 & 4.40013500 & -1.48110800 \\
\hline $\mathrm{H}$ & 2.65717500 & 2.52347400 & 2.19451400 \\
\hline $\mathrm{H}$ & 3.20323600 & 3.96663900 & 0.23908000 \\
\hline $\mathrm{O}$ & -2.03314700 & 1.51475700 & 1.99187000 \\
\hline $\mathrm{C}$ & -3.54913600 & -2.21212900 & -2.53144000 \\
\hline $\mathrm{C}$ & -2.22524300 & -1.93009200 & -2.89647100 \\
\hline $\mathrm{C}$ & -1.28912300 & -1.50001100 & -1.96583900 \\
\hline $\mathrm{C}$ & -1.61680700 & -1.32794200 & -0.58581300 \\
\hline $\mathrm{C}$ & -2.96540900 & -1.65989600 & -0.23804000 \\
\hline $\mathrm{C}$ & -3.89445500 & -2.07345800 & -1.18237700 \\
\hline $\mathrm{H}$ & -4.27643300 & -2.54140000 & -3.26690200 \\
\hline $\mathrm{H}$ & -1.91233200 & -2.05579400 & -3.93109300 \\
\hline $\mathrm{H}$ & -0.27314800 & -1.34150000 & -2.30782200 \\
\hline $\mathrm{H}$ & -3.25943700 & -1.56435000 & 0.80255200 \\
\hline $\mathrm{H}$ & -4.91277300 & -2.28731300 & -0.86227800 \\
\hline $\mathrm{C}$ & -0.70350700 & -0.97468700 & 0.47928700 \\
\hline $\mathrm{C}$ & 0.70747400 & -0.66421200 & 0.24783800 \\
\hline $\mathrm{C}$ & 1.22856600 & 0.00038100 & -0.89262300 \\
\hline $\mathrm{C}$ & 1.63924700 & -0.94267200 & 1.27686200 \\
\hline $\mathrm{C}$ & 2.57401600 & 0.31119200 & -1.01107600 \\
\hline $\mathrm{H}$ & 0.55442700 & 0.35550200 & -1.66401200 \\
\hline $\mathrm{C}$ & 2.99479300 & -0.64593400 & 1.15273500 \\
\hline $\mathrm{H}$ & 1.26461800 & -1.39009500 & 2.19208700 \\
\hline $\mathrm{C}$ & 3.47874100 & -0.02844100 & 0.00139500 \\
\hline $\mathrm{H}$ & 2.93376300 & 0.86212400 & -1.87642600 \\
\hline $\mathrm{H}$ & 3.68708800 & -0.87268500 & 1.96032600 \\
\hline $\mathrm{O}$ & -1.06086300 & -1.27052800 & 1.71778400 \\
\hline $\mathrm{O}$ & 4.80780500 & 0.34876800 & -0.09109300 \\
\hline $\mathrm{C}$ & 5.74151400 & -0.57455100 & -0.70839000 \\
\hline $\mathrm{C}$ & 7.07041900 & 0.16889500 & -0.65679900 \\
\hline $\mathrm{C}$ & 5.81904800 & -1.87057300 & 0.09595500 \\
\hline $\mathrm{C}$ & 5.34328300 & -0.86060600 & -2.15478500 \\
\hline $\mathrm{H}$ & 6.99915700 & 1.10863000 & -1.21249100 \\
\hline $\mathrm{H}$ & 7.33599800 & 0.39546100 & 0.38002200 \\
\hline $\mathrm{H}$ & 7.86524800 & -0.43944000 & -1.09775100 \\
\hline $\mathrm{H}$ & 4.86453300 & -2.40457300 & 0.07640300 \\
\hline $\mathrm{H}$ & 6.58650700 & -2.52502400 & -0.32854400 \\
\hline $\mathrm{H}$ & 6.07990700 & -1.65684300 & 1.13728500 \\
\hline $\mathrm{H}$ & 6.10647000 & -1.48532300 & -2.62907800 \\
\hline $\mathrm{H}$ & 4.38757000 & -1.39003900 & -2.20634100 \\
\hline
\end{tabular}


H $\quad \begin{array}{llll}5.25750500 & 0.07292700 & -2.71973400\end{array}$

$\begin{array}{llll}\mathrm{K} & -0.86901500 & -3.79725000 & 0.94225600\end{array}$

$\begin{array}{llll}\mathrm{K} & -2.36701700 & -0.35660300 & 3.66392100\end{array}$ 
Triplet Complex between $\mathbf{2 4}$ and 17 (counterions)

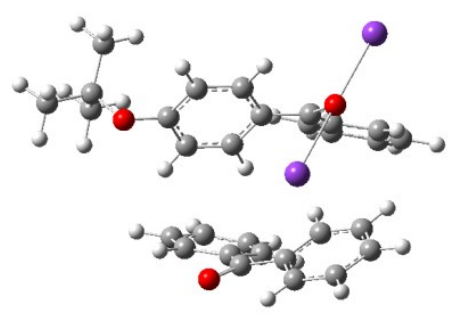

63

$-2585.0997061$

$\begin{array}{lrrr}\mathrm{C} & -3.60714300 & -1.40758700 & -2.73856900 \\ \mathrm{C} & -3.33312300 & -1.13632800 & -1.38890600 \\ \mathrm{C} & -2.19402800 & -1.63499300 & -0.76767500 \\ \mathrm{C} & -1.26500400 & -2.45774500 & -1.46841800 \\ \mathrm{C} & -1.54481100 & -2.68628200 & -2.84860000 \\ \mathrm{C} & -2.68759100 & -2.18487800 & -3.45851200 \\ \mathrm{H} & -4.50295400 & -1.02002500 & -3.21248200 \\ \mathrm{H} & -4.00434500 & -0.50468300 & -0.81380100 \\ \mathrm{H} & -2.00187700 & -1.33697900 & 0.25824400 \\ \mathrm{H} & -0.83555200 & -3.28167900 & -3.41323300 \\ \mathrm{H} & -2.86853800 & -2.40057300 & -4.50870600 \\ \mathrm{C} & -0.02336500 & -3.00173200 & -0.92958200 \\ \mathrm{C} & 0.23808700 & -3.09935500 & 0.52019900 \\ \mathrm{C} & -0.75061500 & -3.12748300 & 1.52975900 \\ \mathrm{C} & 1.58192800 & -3.23186500 & 0.93881800 \\ \mathrm{C} & -0.40660500 & -3.20651000 & 2.87670200 \\ \mathrm{H} & -1.80161200 & -3.12240700 & 1.26228800 \\ \mathrm{C} & 1.92282600 & -3.30220100 & 2.28431000 \\ \mathrm{H} & 2.34945900 & -3.26620300 & 0.17189300 \\ \mathrm{C} & 0.93235700 & -3.27418400 & 3.27150700 \\ \mathrm{H} & -1.19491400 & -3.22513200 & 3.62499500 \\ \mathrm{H} & 2.96934900 & -3.38081200 & 2.56840600 \\ \mathrm{H} & 1.19649200 & -3.32607800 & 4.32317600 \\ \mathrm{O} & 0.88225900 & -3.40504600 & -1.74160800 \\ \mathrm{C} & -3.63633400 & 0.51136500 & 3.36572800 \\ \mathrm{C} & -2.23763700 & 0.48017400 & 3.45143500 \\ \mathrm{C} & 5.19893800 & 2.64574900 & 0.26499600 \\ \mathrm{C} & 5.11175900 & 0.35764200 & 1.30348100 \\ \mathrm{H} & 6.60425800 & -0.29562700 & -0.89941100 \\ \mathrm{H} & 6.67214600 & 1.32304400 & -1.63067700 \\ \mathrm{H} & 7.42787900 & 1.02987300 & -0.04841600 \\ \mathrm{C} & -1.44403900 & 0.86384900 & 2.37965400 \\ \mathrm{C} & -2.01904300 & 1.29076900 & 1.15153100 \\ \mathrm{C} & -3.43922400 & 1.34022300 & 1.09669900 \\ \mathrm{C} & -4.22410400 & 0.95483600 & 2.17721900 \\ \mathrm{H} & -4.24889000 & 0.20591000 & 4.20755500 \\ \mathrm{H} & -1.76007800 & 0.15816900 & 4.37318800 \\ \mathrm{H} & -0.36577000 & 0.85592900 & 2.49815800 \\ \mathrm{H} & -3.90763400 & 1.65503000 & 0.16822200 \\ \mathrm{H} & -1.85761900 & 2.35885000 & -0.97254000 \\ \mathrm{H} & -5.30695400 & 0.99042500 & 2.08844400 \\ \mathrm{C} & -1.25868500 & 1.71741100 & -0.00874500 \\ \mathrm{C} & 0.18717100 & 1.46324000 & -0.15501000 \\ \mathrm{C} & 0.83423600 & 0.30249900 & 0.32030100 \\ \mathrm{C} & 0.95570800 & 2.35910400 & -0.93092400 \\ \mathrm{C} & 2.18261200 & 0.07487500 & 0.06947800 \\ \mathrm{C} & 0.26912200 & -0.46192100 & 0.84710000 \\ \mathrm{H} & 2.30834500 & 2.13942800 & -1.17020300 \\ \mathrm{H} & 2.46795300 & 3.23776700 & -1.34291600 \\ \mathrm{H} & 2.64918200 & -0.84341200 & 0.41187300 \\ \mathrm{H} & 0.75163100 & -0.96054000 \\ \mathrm{H} & 1.14359300 & 0.00412000 \\ \mathrm{H} & & & \end{array}$


$\begin{array}{llll}\mathrm{H} & 4.25789200 & 2.91946400 & 0.75167900\end{array}$

$\begin{array}{llll}\mathrm{H} & 6.02148800 & 2.94474500 & 0.92130000\end{array}$

$\mathrm{H} \quad 5.28367400 \quad 3.20081000 \quad-0.67450700$

$\begin{array}{llll}\mathrm{H} & 5.94709500 & 0.58600000 & 1.97219900\end{array}$

$\begin{array}{llll}\mathrm{H} & 4.18342800 & 0.61925600 & 1.81932200\end{array}$

$\begin{array}{llll}\mathrm{H} & 5.11135400 & -0.71818900 & 1.10201200\end{array}$

$\begin{array}{lllll}\mathrm{K} & -2.70453200 & 4.39399100 & 0.43847800\end{array}$

$\begin{array}{lllll}\text { K } & -1.01835400 & 0.49754200 & -2.77767800\end{array}$ 
Single Point Singlet, Using Triplet Complex (of $\mathbf{2 4}$ and

17, counterions) Optimised Geometry

63

$-2585.0715682$

\begin{tabular}{|c|c|c|c|}
\hline C & -3.60714300 & -1.40758700 & 6900 \\
\hline $\mathrm{C}$ & -3.33312300 & -1.13632800 & -1.38890600 \\
\hline $\mathrm{C}$ & -2.19402800 & -1.63499300 & -0.76767500 \\
\hline $\mathrm{C}$ & -1.26500400 & -2.45774500 & -1.46841800 \\
\hline $\mathrm{C}$ & -1.54481100 & -2.68628200 & -2.84860000 \\
\hline $\mathrm{C}$ & -2.68759100 & -2.18487800 & -3.45851200 \\
\hline $\mathrm{H}$ & -4.50295400 & -1.02002500 & -3.21248200 \\
\hline $\mathrm{H}$ & -4.00434500 & -0.50468300 & -0.81380100 \\
\hline $\mathrm{H}$ & -2.00187700 & -1.33697900 & 0.25824400 \\
\hline $\mathrm{H}$ & -0.83555200 & -3.28167900 & -3.41323300 \\
\hline $\mathrm{H}$ & -2.86853800 & -2.40057300 & -4.50870600 \\
\hline $\mathrm{C}$ & -0.02336500 & -3.00173200 & -0.92958200 \\
\hline $\mathrm{C}$ & 0.23808700 & -3.09935500 & 0.52019900 \\
\hline $\mathrm{C}$ & -0.75061500 & -3.12748300 & 1.52975900 \\
\hline $\mathrm{C}$ & 1.58192800 & -3.23186500 & 0.93881800 \\
\hline $\mathrm{C}$ & -0.40660500 & -3.20651000 & 2.87670200 \\
\hline $\mathrm{H}$ & -1.80161200 & -3.12240700 & 1.26228800 \\
\hline $\mathrm{C}$ & 1.92282600 & -3.30220100 & 2.28431000 \\
\hline $\mathrm{H}$ & 2.34945900 & -3.26620300 & 0.17189300 \\
\hline $\mathrm{C}$ & 0.93235700 & -3.27418400 & 3.27150700 \\
\hline $\mathrm{H}$ & -1.19491400 & -3.22513200 & 3.62499500 \\
\hline $\mathrm{H}$ & 2.96934900 & -3.38081200 & 2.56840600 \\
\hline $\mathrm{H}$ & 1.19649200 & -3.32607800 & 4.32317600 \\
\hline $\mathrm{O}$ & 0.88225900 & -3.40504600 & -1.74160800 \\
\hline $\mathrm{C}$ & -3.63633400 & 0.51136500 & 3.36572800 \\
\hline $\mathrm{C}$ & -2.23763700 & 0.48017400 & 3.45143500 \\
\hline $\mathrm{C}$ & -1.44403900 & 0.86384900 & 2.37965400 \\
\hline $\mathrm{C}$ & -2.01904300 & 1.29076900 & 1.15153100 \\
\hline $\mathrm{C}$ & -3.43922400 & 1.34022300 & 1.09669900 \\
\hline $\mathrm{C}$ & -4.22410400 & 0.95483600 & 2.17721900 \\
\hline $\mathrm{H}$ & -4.24889000 & 0.20591000 & 4.20755500 \\
\hline $\mathrm{H}$ & -1.76007800 & 0.15816900 & 4.37318800 \\
\hline $\mathrm{H}$ & -0.36577000 & 0.85592900 & 2.49815800 \\
\hline $\mathrm{H}$ & -3.90763400 & 1.65503000 & 0.16822200 \\
\hline $\mathrm{H}$ & -5.30695400 & 0.99042500 & 2.08844400 \\
\hline $\mathrm{C}$ & -1.25868500 & 1.71741100 & -0.00874500 \\
\hline $\mathrm{C}$ & 0.18717100 & 1.46324000 & -0.15501000 \\
\hline $\mathrm{C}$ & 0.83423600 & 0.30249900 & 0.32030100 \\
\hline $\mathrm{C}$ & 0.95570800 & 2.35910400 & -0.93092400 \\
\hline $\mathrm{C}$ & 2.18261200 & 0.07487500 & 0.06947800 \\
\hline $\mathrm{H}$ & 0.26912200 & -0.46192100 & 0.84710000 \\
\hline $\mathrm{C}$ & 2.30834500 & 2.13942800 & -1.17020300 \\
\hline $\mathrm{H}$ & 0.46795300 & 3.23776700 & -1.34291600 \\
\hline $\mathrm{C}$ & 2.93544100 & 1.00153000 & -0.65711100 \\
\hline $\mathrm{H}$ & 2.64918200 & -0.84341200 & 0.41187300 \\
\hline $\mathrm{H}$ & 2.89122300 & 2.84111900 & -1.76026700 \\
\hline $\mathrm{O}$ & -1.85761900 & 2.35885000 & -0.97254000 \\
\hline $\mathrm{O}$ & 4.25433000 & 0.75163100 & -0.96054000 \\
\hline $\mathrm{C}$ & 5.27120000 & 1.14359300 & 0.00412000 \\
\hline $\mathrm{C}$ & 6.57744500 & 0.77711400 & -0.68757100 \\
\hline $\mathrm{C}$ & 5.19893800 & 2.64574900 & 0.26499600 \\
\hline $\mathrm{C}$ & 5.11175900 & 0.35764200 & 1.30348100 \\
\hline $\mathrm{H}$ & 6.60425800 & -0.29562700 & -0.89941100 \\
\hline $\mathrm{H}$ & 6.67214600 & 1.32304400 & -1.63067700 \\
\hline $\mathrm{H}$ & 7.42787900 & 1.02987300 & -0.04841600 \\
\hline $\mathrm{H}$ & 4.25789200 & 2.91946400 & 0.75167900 \\
\hline $\mathrm{H}$ & 6.02148800 & 2.94474500 & 0.92130000 \\
\hline $\mathrm{H}$ & 5.28367400 & 3.20081000 & -0.67450700 \\
\hline $\mathrm{H}$ & 5.94709500 & 0.58600000 & 1.97219900 \\
\hline $\mathrm{H}$ & 4.18342800 & 0.61925600 & 1.81932200 \\
\hline
\end{tabular}


$\begin{array}{llll}\mathrm{H} & 5.11135400 & -0.71818900 & 1.10201200\end{array}$

$\begin{array}{lllll}\mathrm{K} & -2.70453200 & 4.39399100 & 0.43847800\end{array}$

$\begin{array}{lllll}\mathrm{K} & & -1.01835400 & 0.49754200 & -2.77767800\end{array}$ 
Reactant Complex for formation of $\mathbf{5 0}$ and $\mathbf{2 1}$ from 45 and 17

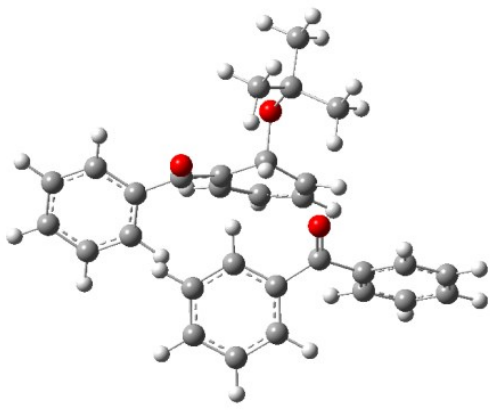

62

$-1385.9139884$

\begin{tabular}{|c|c|c|c|}
\hline $\mathrm{C}$ & 0.86878 & -3.78018 & -1.19840 \\
\hline $\mathrm{C}$ & -0.42615 & -4.16450 & -0.84843 \\
\hline $\mathrm{C}$ & -1.44850 & -3.21782 & -0.81251 \\
\hline $\mathrm{C}$ & -1.18074 & -1.88340 & -1.14343 \\
\hline $\mathrm{C}$ & 0.11634 & -1.50752 & -1.51285 \\
\hline $\mathrm{C}$ & 1.13858 & -2.45061 & -1.52912 \\
\hline $\mathrm{H}$ & 1.66733 & -4.51631 & -1.21387 \\
\hline $\mathrm{H}$ & -0.64083 & -5.19968 & -0.60257 \\
\hline $\mathrm{H}$ & -2.45612 & -3.52239 & -0.54676 \\
\hline $\mathrm{H}$ & 0.33284 & -0.47311 & -1.76423 \\
\hline $\mathrm{H}$ & 2.14656 & -2.14061 & -1.78958 \\
\hline $\mathrm{C}$ & -2.25407 & -0.84279 & -1.17875 \\
\hline $\mathrm{C}$ & -3.46490 & -0.98529 & -0.30734 \\
\hline $\mathrm{C}$ & -3.39445 & -1.54138 & 0.97482 \\
\hline $\mathrm{C}$ & -4.68062 & -0.47524 & -0.77530 \\
\hline $\mathrm{C}$ & -4.53191 & -1.58753 & 1.77814 \\
\hline $\mathrm{H}$ & -2.44404 & -1.90202 & 1.35670 \\
\hline $\mathrm{C}$ & -5.82133 & -0.54128 & 0.02022 \\
\hline $\mathrm{H}$ & -4.71833 & -0.03194 & -1.76577 \\
\hline $\mathrm{C}$ & -5.74699 & -1.09589 & 1.29902 \\
\hline $\mathrm{H}$ & -4.46793 & -2.00292 & 2.77886 \\
\hline $\mathrm{H}$ & -6.76512 & -0.15648 & -0.35299 \\
\hline $\mathrm{H}$ & -6.63392 & -1.13886 & 1.92367 \\
\hline $\mathrm{O}$ & -2.15847 & 0.11797 & -1.93011 \\
\hline $\mathrm{C}$ & 5.97406 & -1.62733 & 0.58832 \\
\hline $\mathrm{C}$ & 4.74793 & -2.14881 & 1.00079 \\
\hline $\mathrm{C}$ & 3.57041 & -1.43439 & 0.77608 \\
\hline $\mathrm{C}$ & 3.60034 & -0.19533 & 0.12548 \\
\hline $\mathrm{C}$ & 4.83421 & 0.30717 & -0.30449 \\
\hline $\mathrm{C}$ & 6.01432 & -0.39388 & -0.06509 \\
\hline $\mathrm{H}$ & 6.89140 & -2.17959 & 0.76953 \\
\hline $\mathrm{H}$ & 4.70608 & -3.11417 & 1.49716 \\
\hline $\mathrm{H}$ & 2.61560 & -1.84712 & 1.09061 \\
\hline $\mathrm{H}$ & 4.85616 & 1.25639 & -0.83260 \\
\hline $\mathrm{H}$ & 6.96477 & 0.01704 & -0.39315 \\
\hline $\mathrm{C}$ & 2.34422 & 0.57543 & -0.21963 \\
\hline $\mathrm{C}$ & 1.36077 & 0.81369 & 0.77125 \\
\hline $\mathrm{C}$ & 1.52335 & 0.46217 & 2.14394 \\
\hline $\mathrm{C}$ & 0.10078 & 1.51725 & 0.35673 \\
\hline $\mathrm{C}$ & 0.46758 & 0.43982 & 3.02104 \\
\hline $\mathrm{H}$ & 2.51113 & 0.17847 & 2.50096 \\
\hline $\mathrm{C}$ & -1.05364 & 1.10480 & 1.22809 \\
\hline $\mathrm{H}$ & -0.10419 & 1.30732 & -0.69854 \\
\hline $\mathrm{C}$ & -0.85579 & 0.67524 & 2.49922 \\
\hline $\mathrm{H}$ & 0.60737 & 0.16300 & 4.06101 \\
\hline $\mathrm{H}$ & -2.06367 & 1.23008 & 0.84484 \\
\hline $\mathrm{H}$ & -1.71724 & 0.46154 & 3.13167 \\
\hline $\mathrm{O}$ & 2.23926 & 0.94471 & -1.42120 \\
\hline $\mathrm{O}$ & 0.30083 & 2.96856 & 0.46853 \\
\hline $\mathrm{C}$ & -0.29047 & 3.80634 & -0.52930 \\
\hline $\mathrm{C}$ & -0.10122 & 5.22450 & 0.00556 \\
\hline $\mathrm{C}$ & 0.44300 & 3.65551 & -1.86570 \\
\hline
\end{tabular}




$\begin{array}{lrrr}\mathrm{C} & -1.78645 & 3.52293 & -0.71186 \\ \mathrm{H} & -0.62155 & 5.33980 & 0.96159 \\ \mathrm{H} & 0.96270 & 5.42751 & 0.16253 \\ \mathrm{H} & -0.49694 & 5.96066 & -0.70172 \\ \mathrm{H} & 0.37585 & 2.63273 & -2.24527 \\ \mathrm{H} & 0.01683 & 4.33899 & -2.60846 \\ \mathrm{H} & 1.50422 & 3.88998 & -1.73735 \\ \mathrm{H} & -2.21294 & 4.24545 & -1.41616 \\ \mathrm{H} & -1.96235 & 2.51846 & -1.11101 \\ \mathrm{H} & -2.31124 & 3.61771 & 0.24440\end{array}$


Transition State for

formation of $\mathbf{5 0}$ and $\mathbf{2 1}$ from

45 and 17

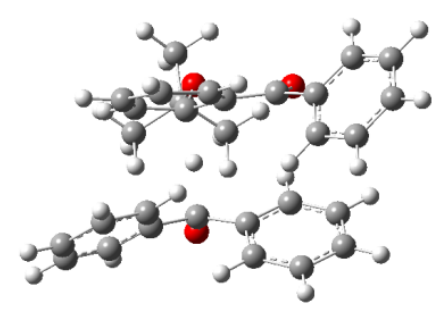

62

$-1385.8589518$

$\begin{array}{llll}\text { C } & 2.45915000 & -2.09826200 & -2.49545400\end{array}$

$\begin{array}{llll}\text { C } & 1.53473500 & -2.98577500 & -1.94950100\end{array}$

C $\quad 0.29762000 \quad-2.52224100 \quad-1.49212100$

C $\quad \begin{array}{llll}\text { C } & -0.03656300 & -1.16606600 & -1.58088400\end{array}$

$\begin{array}{llll}\text { C } & 0.90204200 & -0.28651300 & -2.13301700\end{array}$

$\begin{array}{llll}\text { C } & 2.13825700 & -0.74176700 & -2.58042000\end{array}$

$\mathrm{H} \quad 3.42322900 \quad-2.45669300 \quad-2.84421800$

$\mathrm{H} \quad 1.76820200 \quad-4.04473300 \quad-1.88321200$

$\mathrm{H} \quad-\quad-0.41797100 \quad-3.23329000 \quad-1.09083300$

$\mathrm{H} \quad \begin{array}{llll}0.65489000 & 0.76887100 & -2.19715600\end{array}$

$\mathrm{H} \quad 2.85735000 \quad-0.03517600 \quad-2.98566200$

$\begin{array}{llll}\text { C } & -1.44632800 & -0.63863200 & -1.30801300\end{array}$

$\begin{array}{llll}\text { C } & -2.30644500 & -1.45850000 & -0.36824000\end{array}$

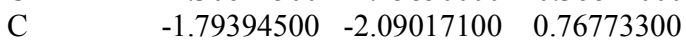

$\begin{array}{llll}\text { C } & -3.67690400 & -1.55895900 & -0.63118100\end{array}$

$\begin{array}{llll}\mathrm{C} & -2.62259000 & -2.83389400 & 1.60490900\end{array}$

$\mathrm{H} \quad-\quad-0.74094900 \quad-1.97704400 \quad 1.01752300$

$\begin{array}{llll}\text { C } & -4.51319500 & -2.29269700 & 0.20959800\end{array}$

$\mathrm{H} \quad-4.06478200 \quad-1.05804800 \quad-1.51300900$

$\begin{array}{llll}\text { C } & -3.98578300 & -2.94132300 & 1.32770500\end{array}$

$\mathrm{H} \quad-2.20479500 \quad-3.31314200 \quad 2.48622100$

$\mathrm{H} \quad-\quad-5.57455600 \quad-2.36497700 \quad-0.01070600$

$\mathrm{H} \quad-4.63257400 \quad-3.51958200 \quad 1.98114500$

$\begin{array}{llll}\mathrm{O} & -2.02501400 & -0.12339200 & -2.32980700\end{array}$

$\begin{array}{llll}\mathrm{C} & 5.55160700 & -0.66090500 & 0.85989100\end{array}$

$\begin{array}{lllll}\mathrm{C} & 4.41034300 & -1.43896900 & 0.66049100\end{array}$

$\begin{array}{lllll}\mathrm{C} & 3.15881400 & -0.83333200 & 0.56267600\end{array}$

$\begin{array}{lllll}\mathrm{C} & 3.03931400 & 0.55723700 & 0.64539000\end{array}$

$\begin{array}{lllll}\mathrm{C} & 4.18900300 & 1.33319400 & 0.81699100\end{array}$

$\begin{array}{llll}\mathrm{C} & 5.43902000 & 0.72807000 & 0.93899700\end{array}$

$\begin{array}{llll}\mathrm{H} & 6.52535600 & -1.13377700 & 0.94645500\end{array}$

$\begin{array}{llll}\mathrm{H} & 4.49432600 & -2.51864100 & 0.57469800\end{array}$

$\begin{array}{llll}\mathrm{H} & 2.26940200 & -1.43622700 & 0.38799400\end{array}$

$\begin{array}{llll}\mathrm{H} & 4.09395500 & 2.41483800 & 0.85496900\end{array}$

$\begin{array}{llll}\mathrm{H} & 6.32455400 & 1.33828000 & 1.09030700\end{array}$

$\begin{array}{lllll}\mathrm{C} & 1.71166600 & 1.25621500 & 0.43706400\end{array}$

$\begin{array}{llll}\mathrm{C} & 0.55592800 & 0.80285700 & 1.20600300\end{array}$

$\begin{array}{lllll}\mathrm{C} & 0.76665800 & 0.00854900 & 2.35775400\end{array}$

$\begin{array}{llll}\text { C } & -0.80943900 & 1.19416700 & 0.84583100\end{array}$

$\begin{array}{llll}\text { C } & -0.24389200 & -0.35784000 & 3.22306300\end{array}$

$\begin{array}{llll}\mathrm{H} & 1.78573400 & -0.26977000 & 2.60595300\end{array}$

$\begin{array}{lllll}\mathrm{C} & -1.83197900 & 0.82534100 & 1.81924400\end{array}$

$\begin{array}{llll}\mathrm{H} & -1.11702900 & 0.37889700 & -0.33478100\end{array}$

$\begin{array}{llll}\mathrm{C} & -1.55743600 & 0.08413900 & 2.93562500\end{array}$

$\mathrm{H} \quad-\quad-0.02891300 \quad-0.92855000 \quad 4.11975000$

$\mathrm{H} \quad-2.83874800 \quad 1.18989400 \quad 1.65301600$

$\mathrm{H} \quad-2.36812100 \quad-0.14510800 \quad 3.62388400$

$\begin{array}{llll}\mathrm{O} & 1.69896200 & 2.17506900 & -0.38907900\end{array}$

$\begin{array}{llll}\mathrm{O} & -0.90626500 & 2.50612700 & 0.37805600\end{array}$

$\begin{array}{llll}\mathrm{C} & -1.81659900 & 3.02382500 & -0.61283500\end{array}$

$\begin{array}{lllll}\mathrm{C} & -1.92298400 & 4.50281800 & -0.24135400\end{array}$

$\begin{array}{llll}\text { C } & -1.18045600 & 2.88084200 & -1.99485000\end{array}$

$\begin{array}{llll}\text { C } & -3.20129800 & 2.37944200 & -0.58348000\end{array}$

$\mathrm{H} \quad-2.33354400 \quad 4.61620800 \quad 0.76670000$

$\mathrm{H} \quad-0.93374400 \quad 4.97018200 \quad-0.27203800$ 
H $\quad-2.57673700 \quad 5.02299700 \quad-0.94827600$

$\mathrm{H} \quad-1.21855100 \quad 1.83993000 \quad-2.32468400$

$\mathrm{H} \quad \begin{array}{llll}-1.73388200 & 3.48987600 & -2.71949700\end{array}$

$\mathrm{H} \quad-0.14304000 \quad 3.22317400 \quad-1.95095200$

$\mathrm{H} \quad-3.79124100 \quad 2.79431500 \quad-1.40779400$

$\mathrm{H} \quad-3.14327400 \quad 1.29815600 \quad-0.73570700$

$\begin{array}{llll}\mathrm{H} & -3.72594600 & 2.60159800 & 0.35085400\end{array}$ 
Product Complex for formation of $\mathbf{5 0}$ and $\mathbf{2 1}$ from 45 and 17

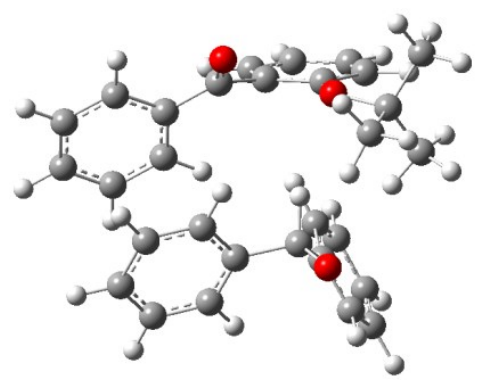

62 $-1385.9151685$

\begin{tabular}{|c|c|c|c|}
\hline 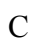 & -4.11678 & 1.54675 & -1.24331 \\
\hline $\mathrm{C}$ & -3.49056 & 2.54731 & -0.50260 \\
\hline $\mathrm{C}$ & -2.09579 & 2.58914 & -0.41347 \\
\hline $\mathrm{C}$ & -1.30488 & 1.63799 & -1.0636 \\
\hline $\mathrm{C}$ & -1.95056 & 0.63811 & -1.802 \\
\hline $\mathrm{C}$ & -3.33833 & 0.58721 & -1.895 \\
\hline $\mathrm{H}$ & -5.20084 & 1.50537 & -1.303 \\
\hline $\mathrm{H}$ & -4.08690 & 3.29488 & 0.014 \\
\hline $\mathrm{H}$ & -1.61894 & 3.37172 & 0.1725 \\
\hline $\mathrm{H}$ & -1.34255 & -0.11404 & -2.304 \\
\hline $\mathrm{H}$ & -3.81694 & -0.20733 & -2.462 \\
\hline $\mathrm{C}$ & 0.23418 & 1.69117 & -1.11272 \\
\hline $\mathrm{C}$ & 0.78802 & 2.36661 & 0.153 \\
\hline $\mathrm{C}$ & 0.95410 & 1.66295 & 1.3523 \\
\hline $\mathrm{C}$ & 1.15720 & 3.71371 & 0.12303 \\
\hline $\mathrm{C}$ & 1.45868 & 2.28750 & 2.49360 \\
\hline $\mathrm{H}$ & 0.71077 & 0.60176 & 1.3849 \\
\hline $\mathrm{C}$ & 1.65533 & 4.34973 & 1.2616 \\
\hline $\mathrm{H}$ & 1.05533 & 4.24130 & -0.82127 \\
\hline $\mathrm{C}$ & 1.80704 & 3.63937 & 2.45380 \\
\hline $\mathrm{H}$ & 1.58971 & 1.71694 & 3.40974 \\
\hline $\mathrm{H}$ & 1.93354 & 5.39967 & 1.2189 \\
\hline $\mathrm{H}$ & 2.20346 & 4.12916 & 3.33859 \\
\hline $\mathrm{O}$ & 0.65855 & 2.26451 & -2.27077 \\
\hline $\mathrm{C}$ & -4.54212 & -1.22490 & 1.0809 \\
\hline $\mathrm{C}$ & -3.46337 & -0.45419 & 1.5139 \\
\hline $\mathrm{C}$ & -2.16289 & -0.82974 & 1.1881 \\
\hline $\mathrm{C}$ & -1.93595 & -1.96861 & 0.4074 \\
\hline $\mathrm{C}$ & -3.02303 & -2.72611 & -0.0409 \\
\hline $\mathrm{C}$ & -4.32165 & -2.36305 & 0.3039 \\
\hline $\mathrm{H}$ & -5.55556 & -0.93273 & 1.3395 \\
\hline $\mathrm{H}$ & -3.63451 & 0.44699 & 2.0942 \\
\hline $\mathrm{H}$ & -1.32835 & -0.21569 & 1.512 \\
\hline $\mathrm{H}$ & -2.83353 & -3.60032 & -0.656 \\
\hline $\mathrm{H}$ & -5.16114 & -2.96243 & -0.0346 \\
\hline $\mathrm{C}$ & -0.56221 & -2.38299 & -0.0319 \\
\hline $\mathrm{C}$ & 0.60638 & -2.05841 & 0.84603 \\
\hline $\mathrm{C}$ & 0.46239 & -2.18140 & 2.2319 \\
\hline $\mathrm{C}$ & 1.87233 & -1.71964 & 0.3030 \\
\hline $\mathrm{C}$ & 1.53878 & -1.99883 & 3.0945 \\
\hline $\mathrm{H}$ & -0.51202 & -2.44212 & 2.6347 \\
\hline $\mathrm{C}$ & 2.95762 & -1.56326 & 1.1761 \\
\hline $\mathrm{H}$ & 0.54516 & 0.61728 & -1.0158 \\
\hline $\mathrm{C}$ & 2.78507 & -1.69695 & 2.5517 \\
\hline $\mathrm{H}$ & 1.40854 & -2.10268 & 4.1661 \\
\hline $\mathrm{H}$ & 3.94186 & -1.33767 & 0.7941 \\
\hline $\mathrm{H}$ & 3.64466 & -1.56296 & 3.2018 \\
\hline $\mathrm{O}$ & -0.42545 & -3.02485 & -1.062 \\
\hline $\mathrm{O}$ & 1.91556 & -1.55853 & -1.028 \\
\hline $\mathrm{C}$ & 3.02181 & -1.00598 & -1.795 \\
\hline $\mathrm{C}$ & 4.09912 & -2.07592 & $-1.959^{\prime}$ \\
\hline $\mathrm{C}$ & 2.34958 & -0.70006 & -3.132 \\
\hline & 3.57043 & 0.30218 & $-1.218 c$ \\
\hline
\end{tabular}




$\begin{array}{rrrr}\mathrm{H} & 4.53438 & -2.37546 & -1.00265 \\ \mathrm{H} & 3.67573 & -2.96235 & -2.44109 \\ \mathrm{H} & 4.90410 & -1.68753 & -2.59092 \\ \mathrm{H} & 1.63553 & 0.12377 & -3.00577 \\ \mathrm{H} & 3.10464 & -0.40211 & -3.86680 \\ \mathrm{H} & 1.83116 & -1.58993 & -3.50268 \\ \mathrm{H} & 4.08167 & 0.83430 & -2.02656 \\ \mathrm{H} & 2.75019 & 0.93709 & -0.87271 \\ \mathrm{H} & 4.29184 & 0.16797 & -0.41191\end{array}$

50<smiles>CCCCOc1ccccc1C(=O)c1ccccc1</smiles>

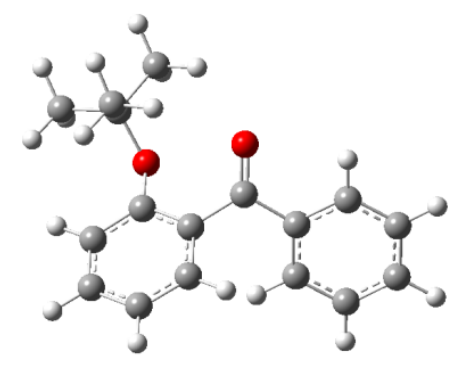

37

$-808.7992613$

$\begin{array}{lrrr}\mathrm{C} & -4.86776 & -0.41049 & -0.62905 \\ \mathrm{C} & -3.99293 & 0.51453 & -1.19720 \\ \mathrm{C} & -2.65544 & 0.54093 & -0.80544 \\ \mathrm{C} & -2.18694 & -0.36987 & 0.14844 \\ \mathrm{C} & -3.06787 & -1.30496 & 0.70652 \\ \mathrm{C} & -4.40471 & -1.32032 & 0.32511 \\ \mathrm{H} & -5.91089 & -0.42490 & -0.92954 \\ \mathrm{H} & -4.35116 & 1.21556 & -1.94399 \\ \mathrm{H} & -1.97460 & 1.25867 & -1.25243 \\ \mathrm{H} & -2.68843 & -2.00890 & 1.44032 \\ \mathrm{H} & -5.08748 & -2.03906 & 0.76667 \\ \mathrm{C} & -0.74922 & -0.41085 & 0.56538 \\ \mathrm{C} & 0.09460 & 0.80873 & 0.33964 \\ \mathrm{C} & -0.35465 & 2.05514 & 0.79162 \\ \mathrm{C} & 1.34508 & 0.71075 & -0.29143 \\ \mathrm{C} & 0.43543 & 3.19110 & 0.64976 \\ \mathrm{H} & -1.32773 & 2.12635 & 1.27053 \\ \mathrm{C} & 2.11583 & 1.86214 & -0.47485 \\ \mathrm{C} & 1.67039 & 3.09009 & 0.00769 \\ \mathrm{H} & 0.08488 & 4.14802 & 1.02109 \\ \mathrm{H} & 3.05647 & 1.78948 & -1.00923 \\ \mathrm{H} & 2.28448 & 3.97414 & -0.13380 \\ \mathrm{O} & -0.28676 & -1.40700 & 1.09710 \\ \mathrm{O} & 1.72581 & -0.49265 & -0.80881 \\ \mathrm{C} & 2.84571 & -1.23020 & -0.22039 \\ \mathrm{C} & 2.99364 & -0.92671 & 1.26669 \\ \mathrm{C} & 2.46376 & -2.68941 & -0.43602 \\ \mathrm{C} & 4.12182 & -0.88977 & -0.98687 \\ \mathrm{H} & 3.30212 & 0.10864 & 1.44016 \\ \mathrm{H} & 2.04948 & -1.11245 & 1.78515 \\ \mathrm{H} & 3.76383 & -1.58197 & 1.68376 \\ \mathrm{H} & 2.30426 & -2.88256 & -1.50120 \\ \mathrm{H} & 3.26215 & -3.34595 & -0.07827 \\ \mathrm{H} & 1.54229 & -2.91432 & 0.10699 \\ \mathrm{H} & 4.93112 & -1.55521 & -0.67041 \\ \mathrm{H} & 3.96323 & -1.02140 & -2.06117 \\ \mathrm{H} & 4.44317 & 0.13809 & -0.79853\end{array}$



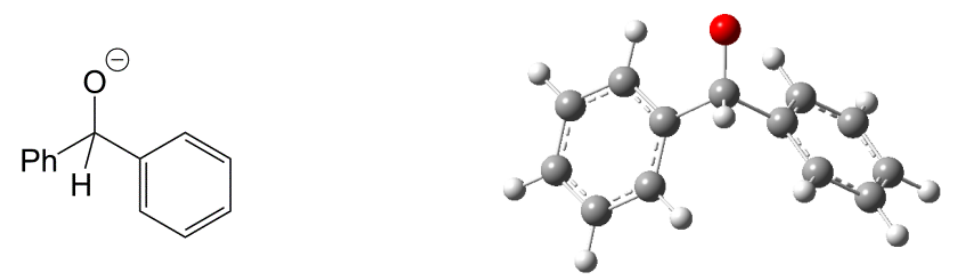

25

$-577.1054866$

$\begin{array}{lrrc}\mathrm{C} & 3.47966 & -1.04717 & 0.60152 \\ \mathrm{C} & 2.59326 & -1.70582 & -0.25566 \\ \mathrm{C} & 1.48398 & -1.03222 & -0.76370 \\ \mathrm{C} & 1.23797 & 0.30637 & -0.43256 \\ \mathrm{C} & 2.13210 & 0.95578 & 0.41825 \\ \mathrm{C} & 3.24405 & 0.28613 & 0.93617 \\ \mathrm{H} & 4.34569 & -1.56867 & 0.99906 \\ \mathrm{H} & 2.77060 & -2.74328 & -0.52675 \\ \mathrm{H} & 0.79519 & -1.55130 & -1.42924 \\ \mathrm{H} & 1.93106 & 1.99761 & 0.65045 \\ \mathrm{H} & 3.93092 & 0.80718 & 1.59844 \\ \mathrm{C} & 0.00695 & 1.06832 & -0.98244 \\ \mathrm{C} & -1.23648 & 0.38687 & -0.37454 \\ \mathrm{C} & -1.59424 & 0.66649 & 0.94976 \\ \mathrm{C} & -2.03258 & -0.49984 & -1.10202 \\ \mathrm{C} & -2.70770 & 0.06886 & 1.53418 \\ \mathrm{H} & -0.98334 & 1.37057 & 1.50958 \\ \mathrm{C} & -3.15487 & -1.10272 & -0.52457 \\ \mathrm{H} & -1.77602 & -0.71805 & -2.13735 \\ \mathrm{C} & -3.49535 & -0.82211 & 0.79713 \\ \mathrm{H} & -2.96745 & 0.29586 & 2.56490 \\ \mathrm{H} & -3.76504 & -1.78471 & -1.11080 \\ \mathrm{H} & -4.36693 & -1.28601 & 1.24959 \\ \mathrm{O} & 0.04618 & 2.40220 & -0.76372 \\ \mathrm{H} & -0.02470 & 0.78953 & -2.06733\end{array}$


Reactant Complex for formation of $\mathbf{2 2}$ and $\mathbf{2 1}$ from 20 and 17

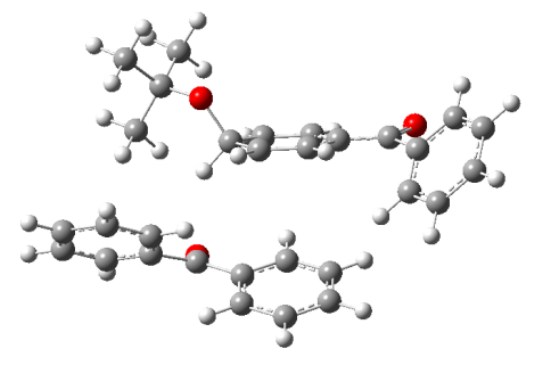

62

$-1385.9144795$

$\begin{array}{llll}\text { C } & -6.46454 & -0.56985 & -1.69885 \\ \text { C } & -5.30953 & -1.29211 & -1.39933\end{array}$

$\begin{array}{llll}\mathrm{C} & -5.30953 & -1.29211 & -1.39933\end{array}$

$\begin{array}{llll}\text { C } & -4.32036 & -0.72919 & -0.59210\end{array}$

$\begin{array}{llll}\text { C } & -4.47476 & 0.55828 & -0.06552\end{array}$

$\begin{array}{llll}\mathrm{C} & -5.64935 & 1.26405 & -0.35177\end{array}$

$\begin{array}{llll}\text { C } & -6.63128 & 0.71305 & -1.17248\end{array}$

$\begin{array}{llll}\mathrm{H} & -7.23180 & -1.00443 & -2.33268\end{array}$

$\begin{array}{llll}\mathrm{H} & -5.17811 & -2.29619 & -1.79273\end{array}$

$\begin{array}{llll}\mathrm{H} & -3.42252 & -1.29432 & -0.35726\end{array}$

$\begin{array}{llll}\mathrm{H} & -5.78238 & 2.25219 & 0.07966\end{array}$

$\begin{array}{llll}\mathrm{H} & -7.52951 & 1.28020 & -1.39887\end{array}$

$\begin{array}{llll}\mathrm{C} & -3.46540 & 1.17460 & 0.87828\end{array}$

$\begin{array}{llll}\mathrm{C} & -2.09106 & 1.17147 & 0.54095\end{array}$

$\begin{array}{llll}\mathrm{C} & -1.55147 & 0.75794 & -0.73099\end{array}$

$\begin{array}{llll}\text { C } & -1.11878 & 1.59763 & 1.51559\end{array}$

$\begin{array}{llll}\mathrm{C} & -0.22534 & 0.77634 & -1.00947\end{array}$

$\begin{array}{llll}\mathrm{H} & -2.23261 & 0.41947 & -1.50834\end{array}$

$\begin{array}{llll}\mathrm{C} & 0.21477 & 1.62300 & 1.27868\end{array}$

$\begin{array}{llll}\mathrm{H} & -1.49209 & 1.85889 & 2.50415\end{array}$

$\begin{array}{llll}\mathrm{C} & 0.81308 & 1.29405 & -0.05944\end{array}$

$\begin{array}{llll}\mathrm{H} & 0.13079 & 0.44849 & -1.98461\end{array}$

$\begin{array}{llll}\mathrm{H} & 0.89751 & 1.87019 & 2.08935\end{array}$

$\begin{array}{llll}\mathrm{O} & -3.93884 & 1.66770 & 1.94111\end{array}$

$\begin{array}{llll}\mathrm{H} & 1.62116 & 0.55831 & 0.05483\end{array}$

$\begin{array}{llll}\mathrm{O} & 1.42558 & 2.43833 & -0.73226\end{array}$

$\begin{array}{llll}\mathrm{C} & 2.65093 & 3.00336 & -0.24451\end{array}$

$\begin{array}{llll}\text { C } & 3.32006 & 3.58270 & -1.49209\end{array}$

$\begin{array}{llll}\mathrm{C} & 2.35194 & 4.13847 & 0.74228\end{array}$

$\begin{array}{llll}\mathrm{C} & 3.58308 & 1.96964 & 0.39249\end{array}$

$\begin{array}{llll}\mathrm{H} & 3.55240 & 2.78051 & -2.20007\end{array}$

$\begin{array}{llll}\mathrm{H} & 2.64579 & 4.29276 & -1.98107\end{array}$

$\begin{array}{llll}\mathrm{H} & 4.24732 & 4.10338 & -1.23200\end{array}$

$\begin{array}{llll}\mathrm{H} & 1.90557 & 3.76070 & 1.66460\end{array}$

$\begin{array}{llll}\mathrm{H} & 3.27336 & 4.67306 & 0.99853\end{array}$

$\begin{array}{llll}\mathrm{H} & 1.65325 & 4.84762 & 0.28754\end{array}$

$\begin{array}{llll}\mathrm{H} & 4.52335 & 2.46087 & 0.66364\end{array}$

$\begin{array}{llll}\mathrm{H} & 3.16094 & 1.53025 & 1.30271\end{array}$

$\begin{array}{llll}\mathrm{H} & 3.81035 & 1.16096 & -0.31099\end{array}$

$\begin{array}{llll}\text { C } & 5.23823 & -1.15398 & -1.81266\end{array}$

$\begin{array}{llll}\mathrm{C} & 3.89354 & -1.17497 & -2.18376\end{array}$

$\begin{array}{llll}\text { C } & 2.90849 & -1.40003 & -1.22400\end{array}$

$\begin{array}{llll}\mathrm{C} & 3.26510 & -1.58644 & 0.11681\end{array}$

$\begin{array}{llll}\mathrm{C} & 4.61447 & -1.55010 & 0.48509\end{array}$

$\begin{array}{llll}\mathrm{C} & 5.59882 & -1.34626 & -0.47737\end{array}$

$\begin{array}{llll}\mathrm{H} & 6.00457 & -0.98330 & -2.56246\end{array}$

$\begin{array}{llll}\mathrm{H} & 3.61046 & -1.00922 & -3.21835\end{array}$

$\begin{array}{llll}\mathrm{H} & 1.86088 & -1.38921 & -1.51141\end{array}$

$\begin{array}{llll}\mathrm{H} & 4.87589 & -1.67513 & 1.53135\end{array}$

$\begin{array}{llll}\mathrm{H} & 6.64469 & -1.32748 & -0.18765\end{array}$

$\begin{array}{llll}\mathrm{C} & 2.23681 & -1.70206 & 1.20173\end{array}$

$\begin{array}{llll}\text { C } & 0.89312 & -2.28310 & 0.90087\end{array}$

$\begin{array}{llll}\text { C } & 0.71319 & -3.28382 & -0.06201\end{array}$

$\begin{array}{llll}\mathrm{C} & -0.20257 & -1.82822 & 1.64379\end{array}$

$\begin{array}{llll}\text { C } & -0.55454 & -3.81879 & -0.28186\end{array}$ 


$\begin{array}{lrrr}\mathrm{H} & 1.56280 & -3.65889 & -0.62486 \\ \mathrm{C} & -1.47091 & -2.34825 & 1.40753 \\ \mathrm{H} & -0.05275 & -1.04447 & 2.37815 \\ \mathrm{C} & -1.64702 & -3.34468 & 0.44512 \\ \mathrm{H} & -0.68949 & -4.60215 & -1.02068 \\ \mathrm{H} & -2.32258 & -1.97009 & 1.96536 \\ \mathrm{H} & -2.63690 & -3.75392 & 0.26288 \\ \mathrm{O} & 2.49792 & -1.30172 & 2.32807\end{array}$


Transition State for

formation of $\mathbf{2 2}$ and $\mathbf{2 1}$ from

20 and 17

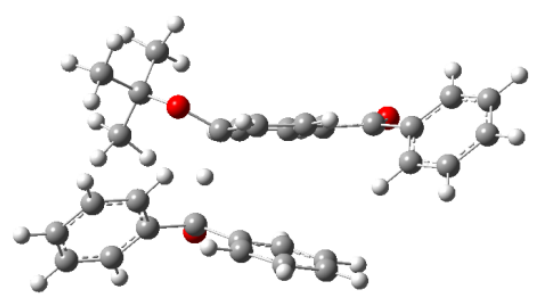

62

$-1385.8777800$

$\begin{array}{llll}\text { C } & -6.58335800 & -0.72169400 & -1.34930600\end{array}$

$\begin{array}{llll}\text { C } & -5.38328800 & -1.39153200 & -1.11275800\end{array}$

$\begin{array}{llll}\text { C } & -4.34502500 & -0.75194500 & -0.43513000\end{array}$

$\begin{array}{llll}\text { C } & -4.50276800 & 0.55969300 & 0.02545000\end{array}$

$\begin{array}{lllll}\mathrm{C} & & -5.71930600 & 1.21622700 & -0.19495400\end{array}$

$\begin{array}{lllll}\text { C } & -6.74893600 & 0.58643600 & -0.88980900\end{array}$

$\mathrm{H} \quad \begin{array}{lllll}\mathrm{H} & -7.38845900 & -1.21790500 & -1.88273700\end{array}$

$\mathrm{H} \quad-5.25325900 \quad-2.41450000 \quad-1.45369200$

$\mathrm{H} \quad-3.41521200 \quad-1.27972200 \quad-0.24503100$

$\mathrm{H} \quad-5.84498800 \quad 2.22541700 \quad 0.18599800$

$\mathrm{H} \quad-7.68268100 \quad 1.11113000 \quad-1.06828300$

$\begin{array}{llll}\text { C } & -3.44474200 & 1.27204700 & 0.83140600\end{array}$

$\begin{array}{llll}\mathrm{C} & -2.05581700 & 1.20072200 & 0.43594400\end{array}$

$\begin{array}{llll}\text { C } & -1.59694900 & 0.69744000 & -0.81446900\end{array}$

$\begin{array}{llll}\text { C } & -1.06827300 & 1.74230700 & 1.29908300\end{array}$

$\begin{array}{llll}\text { C } & -0.27392800 & 0.71587700 & -1.15541000\end{array}$

$\mathrm{H} \quad-2.31136600 \quad 0.33539200 \quad-1.54837600$

$\begin{array}{llll}\mathrm{C} & 0.26432500 & 1.79562000 & 0.98112000\end{array}$

$\begin{array}{llll}\mathrm{H} & -1.39986200 & 2.15032100 & 2.25063300\end{array}$

$\begin{array}{llll}\mathrm{C} & 0.75846600 & 1.20774900 & -0.25428600\end{array}$

$\begin{array}{llll}\mathrm{H} & 0.05352600 & 0.36349500 & -2.12985500\end{array}$

$\mathrm{H} \quad \begin{array}{llll}\mathrm{H} & 0.96269400 & 2.20679300 & 1.69813600\end{array}$

$\begin{array}{llll}\mathrm{O} & -3.83047100 & 1.91667000 & 1.82363900\end{array}$

$\begin{array}{llll}\mathrm{H} & 1.37658400 & 0.08215100 & 0.23094700\end{array}$

$\begin{array}{llll}\mathrm{O} & 1.82005500 & 1.73650500 & -0.99417800\end{array}$

$\begin{array}{lllll}\mathrm{C} & 2.82242900 & 2.62885900 & -0.46580200\end{array}$

$\begin{array}{llll}\mathrm{C} & 3.78547700 & 2.78143900 & -1.64250300\end{array}$

$\begin{array}{llll}\text { C } & 2.21290100 & 3.99808100 & -0.14120600\end{array}$

$\begin{array}{llll}\mathrm{C} & 3.57211600 & 2.02929400 & 0.72629800\end{array}$

$\mathrm{H} \quad 4.15534000 \quad 1.79666800 \quad-1.94413000$

$\mathrm{H} \quad 3.28115500 \quad 3.24837900 \quad-2.49419500$

$\mathrm{H} \quad 4.63718700 \quad 3.40452800 \quad-1.35336500$

$\mathrm{H} \quad \begin{array}{llll}\mathrm{H} & 1.61314400 & 3.99442700 & 0.76931600\end{array}$

$\mathrm{H} \quad 3.01922700 \quad 4.72735800 \quad-0.01252200$

$\begin{array}{llll}\mathrm{H} & 1.58076300 & 4.32559200 & -0.97242400\end{array}$

$\begin{array}{llll}\mathrm{H} & 4.17665400 & 2.81064100 & 1.19917900\end{array}$

$\begin{array}{llll}\mathrm{H} & 2.90407000 & 1.59760400 & 1.47667700\end{array}$

$\begin{array}{llll}\mathrm{H} & 4.24131800 & 1.23205300 & 0.38994700\end{array}$

$\begin{array}{llll}\mathrm{C} & 5.63616600 & -1.60899000 & -0.94659100\end{array}$

$\begin{array}{lllll}\mathrm{C} & 4.52376100 & -1.24800400 & -1.70983900\end{array}$

$\begin{array}{llll}\text { C } & 3.28898400 & -1.04654800 & -1.09569500\end{array}$

$\begin{array}{lllll}\mathrm{C} & & 3.14483600 & -1.20367000 & 0.28746300\end{array}$

$\begin{array}{llll}\mathrm{C} & 4.26499400 & -1.55914900 & 1.04450600\end{array}$

$\begin{array}{llll}\mathrm{C} & 5.50189200 & -1.76565600 & 0.43347800\end{array}$

$\mathrm{H} \quad 6.60020100 \quad-1.75963000 \quad-1.42322000$

$\mathrm{H} \quad 4.62217100 \quad-1.10797000 \quad-2.78270500$

$\mathrm{H} \quad 2.43726200 \quad-0.72225600 \quad-1.68865000$

$\mathrm{H} \quad \begin{array}{llll}\mathrm{H} & 4.15209300 & -1.64969800 & 2.12082300\end{array}$

$\begin{array}{llll}\mathrm{H} & 6.36354800 & -2.04111600 & 1.03491600\end{array}$

$\begin{array}{llll}\mathrm{C} & 1.83566300 & -0.94037200 & 1.01533000\end{array}$

$\begin{array}{llll}\mathrm{C} & 0.66977900 & -1.85877000 & 0.67276400\end{array}$

$\begin{array}{llll}\text { C } & 0.64358600 & -2.72832400 & -0.42366300\end{array}$

$\begin{array}{lllll}\mathrm{C} & & -0.46101600 & -1.78505300 & 1.49588900\end{array}$

$\begin{array}{llll}\mathrm{C} & -0.48813500 & -3.50161700 & -0.69248900\end{array}$

$\mathrm{H} \quad \begin{array}{llll}\mathrm{C} & 1.50906300 & -2.81940700 & -1.07175700\end{array}$ 
$\begin{array}{llll}\text { C } & -1.58930600 & -2.55419400 & 1.22969800\end{array}$

$\begin{array}{llll}\mathrm{H} & -0.43255500 & -1.10698900 & 2.34210800\end{array}$

$\begin{array}{llll}\text { C } & -1.60984200 & -3.41588700 & 0.12984800\end{array}$

$\mathrm{H} \quad-\quad-0.48808700 \quad-4.17392000 \quad-1.54564600$

$\mathrm{H} \quad \begin{array}{llll}-2.45938500 & -2.47873600 & 1.87698100\end{array}$

$\mathrm{H} \quad-2.49178400 \quad-4.01404000 \quad-0.08230400$

$\begin{array}{llll}\text { O } & 1.90460500 & -0.51922400 & 2.22266700\end{array}$ 
Product Complex for formation of $\mathbf{2 2}$ and $\mathbf{2 1}$ from 20 and 17

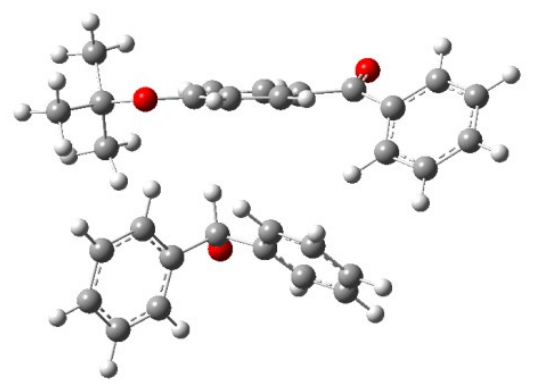

62

$-1385.9218525$

\begin{tabular}{|c|c|c|c|}
\hline & 5.95010 & 0.77914 & -1.00308 \\
\hline $\mathrm{C}$ & 4.64208 & 1.21209 & -0.78994 \\
\hline $\mathrm{C}$ & 3.68860 & 0.34245 & -0.26061 \\
\hline $\mathrm{C}$ & 4.05525 & -0.96734 & 0.07071 \\
\hline $\mathrm{C}$ & 5.37518 & -1.39134 & -0.12476 \\
\hline 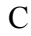 & 6.31788 & -0.52633 & -0.67103 \\
\hline $\mathrm{H}$ & 6.68363 & 1.46006 & -1.42393 \\
\hline $\mathrm{H}$ & 4.35746 & 2.22984 & -1.03407 \\
\hline $\mathrm{H}$ & 2.67299 & 0.69598 & -0.08887 \\
\hline $\mathrm{H}$ & 5.64620 & -2.40571 & 0.15169 \\
\hline $\mathrm{H}$ & 7.33590 & -0.86587 & -0.83424 \\
\hline $\mathrm{C}$ & 3.09771 & -1.93392 & 0.69871 \\
\hline $\mathrm{C}$ & 1.67646 & -1.96645 & 0.26529 \\
\hline $\mathrm{C}$ & 1.24570 & -1.51159 & -0.99164 \\
\hline $\mathrm{C}$ & 0.73839 & -2.56143 & 1.11480 \\
\hline $\mathrm{C}$ & -0.07893 & -1.64668 & -1.3698 \\
\hline $\mathrm{H}$ & 1.95145 & -1.06618 & -1.6861 \\
\hline $\mathrm{C}$ & -0.59646 & -2.68913 & 0.7540 \\
\hline $\mathrm{H}$ & 1.06927 & -2.92595 & 2.0822 \\
\hline $\mathrm{C}$ & -1.02166 & -2.21778 & -0.49724 \\
\hline $\mathrm{H}$ & -0.42266 & -1.29491 & -2.337 \\
\hline H & -1.28397 & -3.14040 & 1.4530 \\
\hline $\mathrm{O}$ & 3.50619 & -2.70841 & 1.55701 \\
\hline $\mathrm{H}$ & -1.07133 & 0.17644 & 0.5259 \\
\hline $\mathrm{O}$ & -2.28106 & -2.24582 & -0.982 \\
\hline $\mathrm{C}$ & -3.45740 & -2.67544 & -0.2452 \\
\hline $\mathrm{C}$ & -4.58709 & -2.32630 & -1.2117 \\
\hline $\mathrm{C}$ & -3.41940 & -4.18649 & -0.0218 \\
\hline C & -3.64173 & -1.87753 & 1.0474 \\
\hline $\mathrm{H}$ & -4.62846 & -1.24370 & $-1.365 t$ \\
\hline $\mathrm{H}$ & -4.42439 & -2.81579 & -2.1761 \\
\hline $\mathrm{H}$ & -5.54451 & -2.66065 & -0.8034 \\
\hline $\mathrm{H}$ & -2.60209 & -4.49900 & 0.6302 \\
\hline $\mathrm{H}$ & -4.35860 & -4.50422 & 0.4405 \\
\hline $\mathrm{H}$ & -3.31423 & -4.70143 & -0.981 \\
\hline $\mathrm{H}$ & -4.67328 & -2.00447 & 1.3894 \\
\hline $\mathrm{H}$ & -2.98656 & -2.19213 & 1.8604 \\
\hline $\mathrm{H}$ & -3.47091 & -0.81359 & 0.8569 \\
\hline $\mathrm{C}$ & -4.74981 & 2.92631 & -0.7634 \\
\hline $\mathrm{C}$ & -4.14499 & 1.82096 & -1.3608 \\
\hline C & -3.00419 & 1.25268 & -0.7874 \\
\hline $\mathrm{C}$ & -2.45007 & 1.77419 & 0.3858 \\
\hline $\mathrm{C}$ & -3.07359 & 2.87548 & 0.98213 \\
\hline 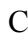 & -4.20841 & 3.45152 & 0.4137 \\
\hline & -5.63778 & 3.37003 & -1.2042 \\
\hline & -4.56466 & 1.39595 & -2.2692 \\
\hline & -2.54677 & 0.37588 & -1.24670 \\
\hline & -2.65687 & 3.26291 & 1.9085 \\
\hline$H$ & -4.67795 & 4.30888 & 0.8888 \\
\hline C & -1.18677 & 1.16507 & 1.03110 \\
\hline & 0.01271 & 1.99802 & 0.51186 \\
\hline & 0.30932 & 2.10106 & -0.8547 \\
\hline & 0.81857 & 2.68703 & 1.4186 \\
\hline
\end{tabular}




$\begin{array}{lccc}\mathrm{C} & 1.35871 & 2.90009 & -1.30488 \\ \mathrm{H} & -0.29795 & 1.55508 & -1.57483 \\ \mathrm{C} & 1.87311 & 3.49113 & 0.97512 \\ \mathrm{H} & 0.58841 & 2.57530 & 2.47431 \\ \mathrm{C} & 2.13864 & 3.61154 & -0.38795 \\ \mathrm{H} & 1.56997 & 2.97100 & -2.36887 \\ \mathrm{H} & 2.48583 & 4.02786 & 1.69499 \\ \mathrm{H} & 2.94981 & 4.24600 & -0.73476 \\ \mathrm{O} & -1.25206 & 1.08132 & 2.37987\end{array}$

22<smiles>CCCCOc1ccc(C(=O)c2ccccc2)cc1</smiles>

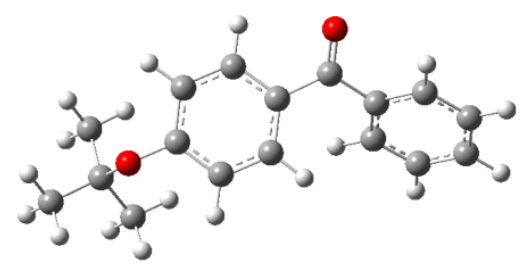

37

$-808.8042505$

$\begin{array}{lrcc}\mathrm{C} & -5.12732 & -1.71741 & 0.14505 \\ \mathrm{C} & -3.85453 & -2.02500 & 0.62451 \\ \mathrm{C} & -2.84443 & -1.06537 & 0.58859 \\ \mathrm{C} & -3.11192 & 0.21369 & 0.08763 \\ \mathrm{C} & -4.39700 & 0.52341 & -0.37266 \\ \mathrm{C} & -5.39819 & -0.44222 & -0.35537 \\ \mathrm{H} & -5.90995 & -2.46966 & 0.16485 \\ \mathrm{H} & -3.64782 & -3.01149 & 1.02689 \\ \mathrm{H} & -1.85694 & -1.30524 & 0.97139 \\ \mathrm{H} & -4.59371 & 1.52318 & -0.74744 \\ \mathrm{H} & -6.38912 & -0.20279 & -0.72771 \\ \mathrm{C} & -2.08051 & 1.29930 & 0.08730 \\ \mathrm{C} & -0.64158 & 0.95759 & -0.11928 \\ \mathrm{C} & -0.23732 & -0.14893 & -0.87643 \\ \mathrm{C} & 0.32901 & 1.82256 & 0.40201 \\ \mathrm{C} & 1.11436 & -0.39340 & -1.09637 \\ \mathrm{H} & -0.97752 & -0.80832 & -1.31892 \\ \mathrm{C} & 1.68006 & 1.57389 & 0.19888 \\ \mathrm{H} & 0.00928 & 2.69203 & 0.96771 \\ \mathrm{C} & 2.07628 & 0.45632 & -0.54458 \\ \mathrm{H} & 1.43726 & -1.23528 & -1.69986 \\ \mathrm{H} & 2.43658 & 2.24170 & 0.59759 \\ \mathrm{O} & -2.42057 & 2.46247 & 0.25412 \\ \mathrm{O} & 3.40163 & 0.24156 & -0.81192 \\ \mathrm{C} & 4.18985 & -0.54608 & 0.13244 \\ \mathrm{C} & 5.55449 & -0.63359 & -0.53621 \\ \mathrm{C} & 4.28721 & 0.17725 & 1.47232 \\ \mathrm{C} & 3.57881 & -1.93378 & 0.30347 \\ \mathrm{H} & 5.46855 & -1.12827 & -1.50782 \\ \mathrm{H} & 5.96780 & 0.36767 & -0.68676 \\ \mathrm{H} & 6.24312 & -1.20689 & 0.09041 \\ \mathrm{H} & 3.31053 & 0.25320 & 1.95913 \\ \mathrm{H} & 4.95317 & -0.37923 & 2.13837 \\ \mathrm{H} & 4.69474 & 1.18343 & 1.33520 \\ \mathrm{H} & 4.23188 & -2.54288 & 0.93488 \\ \mathrm{H} & 2.59666 & -1.88321 & 0.78300 \\ \mathrm{H} & 3.47332 & -2.42937 & -0.66638\end{array}$


Reactant Complex for formation of $\mathbf{2 3}$ and $\mathbf{H O}^{t} \mathbf{B u}$ from 21 and $\mathbf{O t B u}$ anion

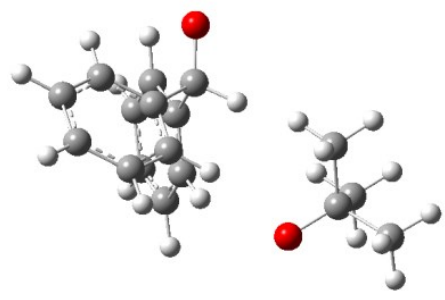

39

$-810.1530973$

$\begin{array}{lrrr}\mathrm{C} & 0.79226 & 3.75659 & -1.07679 \\ \mathrm{C} & -0.26555 & 2.85112 & -1.15924 \\ \mathrm{C} & -0.24264 & 1.66189 & -0.42304 \\ \mathrm{C} & 0.84350 & 1.36498 & 0.40881 \\ \mathrm{C} & 1.89558 & 2.28386 & 0.49314 \\ \mathrm{C} & 1.87702 & 3.46695 & -0.24387 \\ \mathrm{H} & 0.77098 & 4.68055 & -1.64813 \\ \mathrm{H} & -1.12077 & 3.07048 & -1.79422 \\ \mathrm{H} & -1.08963 & 0.97471 & -0.50194 \\ \mathrm{H} & 2.72420 & 2.05641 & 1.15931 \\ \mathrm{H} & 2.70461 & 4.16803 & -0.16783 \\ \mathrm{C} & 0.91269 & 0.06144 & 1.23394 \\ \mathrm{C} & 1.70065 & -0.96116 & 0.37797 \\ \mathrm{C} & 1.20028 & -1.45244 & -0.83571 \\ \mathrm{C} & 2.94456 & -1.41753 & 0.81577 \\ \mathrm{C} & 1.92711 & -2.36922 & -1.59343 \\ \mathrm{H} & 0.22748 & -1.11171 & -1.18756 \\ \mathrm{C} & 3.68201 & -2.33175 & 0.05831 \\ \mathrm{H} & 3.30620 & -1.04234 & 1.76898 \\ \mathrm{C} & 3.17729 & -2.81160 & -1.15012 \\ \mathrm{H} & 1.51975 & -2.74221 & -2.52956 \\ \mathrm{H} & 4.65007 & -2.67534 & 0.41464 \\ \mathrm{H} & 3.74587 & -3.52586 & -1.73901 \\ \mathrm{O} & 1.41894 & 0.23330 & 2.47841 \\ \mathrm{H} & -0.13505 & -0.32907 & 1.22354 \\ \mathrm{O} & -3.09021 & -0.10940 & -1.13593 \\ \mathrm{C} & -3.63866 & -0.67787 & -0.01520 \\ \mathrm{C} & -3.44313 & 0.22523 & 1.22696 \\ \mathrm{C} & -5.15979 & -0.91057 & -0.19015 \\ \mathrm{C} & -2.98813 & -2.04847 & 0.29664 \\ \mathrm{H} & -2.37264 & 0.38524 & 1.40148 \\ \mathrm{H} & -3.90533 & 1.20343 & 1.04314 \\ \mathrm{H} & -3.88301 & -0.20079 & 2.13956 \\ \mathrm{H} & -5.33215 & -1.56598 & -1.05294 \\ \mathrm{H} & -5.63040 & -1.36665 & 0.69221 \\ \mathrm{H} & -5.65363 & 0.04864 & -0.38947 \\ \mathrm{H} & -3.40858 & -2.52871 & 1.19138 \\ \mathrm{H} & -3.12865 & -2.72289 & -0.55734 \\ \mathrm{H} & -1.90957 & -1.91573 & 0.45002 \\ & & & \end{array}$


Transition State for formation of $\mathbf{2 3}$ and $\mathrm{HO}^{t} \mathbf{B u}$ from 21 and $\mathrm{O} t \mathrm{Bu}$ anion

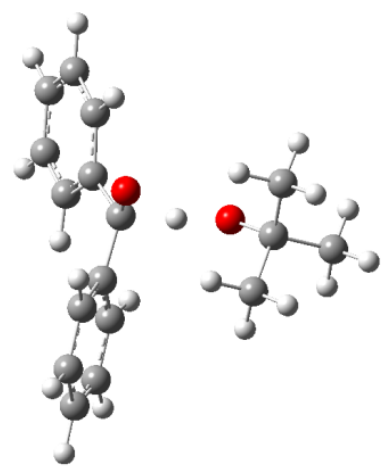

39

$-810.1171016$

\begin{tabular}{llrr}
$\mathrm{C}$ & 2.45006 & -3.33827 & -0.37560 \\
$\mathrm{C}$ & 1.74524 & -2.63590 & -1.36125 \\
$\mathrm{C}$ & 0.83272 & -1.64369 & -1.01452 \\
$\mathrm{C}$ & 0.56171 & -1.31193 & 0.33497 \\
$\mathrm{C}$ & 1.31259 & -2.00875 & 1.30656 \\
$\mathrm{C}$ & 2.22684 & -3.00411 & 0.96231 \\
$\mathrm{H}$ & 3.16774 & -4.10741 & -0.64707 \\
$\mathrm{H}$ & 1.92720 & -2.84994 & -2.41244 \\
$\mathrm{H}$ & 0.35810 & -1.06934 & -1.80508 \\
$\mathrm{H}$ & 1.15741 & -1.72466 & 2.34241 \\
$\mathrm{H}$ & 2.77529 & -3.52242 & 1.74691 \\
$\mathrm{C}$ & -0.32282 & -0.18568 & 0.75624 \\
$\mathrm{C}$ & -1.73069 & -0.23462 & 0.27966 \\
$\mathrm{C}$ & -2.23227 & -0.96422 & -0.82969 \\
$\mathrm{C}$ & -2.68280 & 0.56855 & 0.96076 \\
$\mathrm{C}$ & -3.55724 & -0.86196 & -1.24474 \\
$\mathrm{H}$ & -1.58341 & -1.64562 & -1.36867 \\
$\mathrm{C}$ & -4.00524 & 0.67509 & 0.53739 \\
$\mathrm{H}$ & -2.33663 & 1.10544 & 1.83800 \\
$\mathrm{C}$ & -4.46485 & -0.03048 & -0.57886 \\
$\mathrm{H}$ & -3.88857 & -1.45161 & -2.09766 \\
$\mathrm{H}$ & -4.69083 & 1.31410 & 1.09147 \\
$\mathrm{H}$ & -5.49616 & 0.05009 & -0.90987 \\
$\mathrm{O}$ & -0.16335 & 0.21862 & 2.05690 \\
$\mathrm{H}$ & 0.09301 & 0.80810 & -0.08321 \\
$\mathrm{O}$ & 0.46724 & 1.79918 & -0.85988 \\
$\mathrm{C}$ & 1.60256 & 2.42403 & -0.34244 \\
$\mathrm{C}$ & 2.66572 & 1.37890 & 0.04528 \\
$\mathrm{C}$ & 2.18833 & 3.36655 & -1.40392 \\
$\mathrm{C}$ & 1.23453 & 3.23144 & 0.91511 \\
$\mathrm{H}$ & 2.25666 & 0.71613 & 0.81557 \\
$\mathrm{H}$ & 2.92106 & 0.76622 & -0.82823 \\
$\mathrm{H}$ & 3.58160 & 1.85200 & 0.42384 \\
$\mathrm{H}$ & 1.44272 & 4.11837 & -1.68828 \\
$\mathrm{H}$ & 3.08504 & 3.88635 & -1.04099 \\
$\mathrm{H}$ & 2.45733 & 2.79533 & -2.30014 \\
$\mathrm{H}$ & 2.10961 & 3.71622 & 1.36884 \\
$\mathrm{H}$ & 0.50354 & 4.00798 & 0.65701 \\
$\mathrm{H}$ & 0.78180 & 2.54251 & 1.63794 \\
& & & \\
\hline
\end{tabular}


Product Complex for formation of 23 and $\mathrm{HO}^{t} \mathbf{B u}$ from 21 and $\mathrm{O} t \mathrm{Bu}$ anion

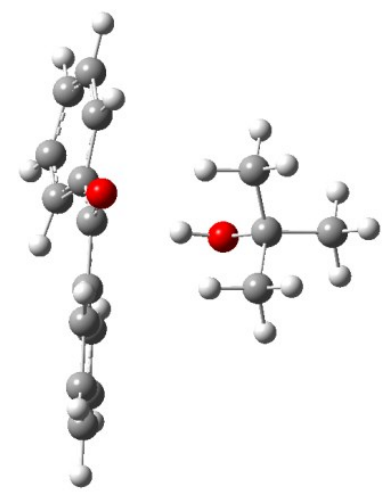

39

$-810.1414320$

$\begin{array}{lrrr}\mathrm{C} & 3.90670 & -1.50900 & -0.66151 \\ \mathrm{C} & 2.78043 & -1.46925 & -1.50330 \\ \mathrm{C} & 1.49937 & -1.27112 & -1.00955 \\ \mathrm{C} & 1.23461 & -1.09289 & 0.39383 \\ \mathrm{C} & 2.41468 & -1.08113 & 1.21856 \\ \mathrm{C} & 3.68709 & -1.29462 & 0.70921 \\ \mathrm{H} & 4.90363 & -1.67282 & -1.05904 \\ \mathrm{H} & 2.91055 & -1.57667 & -2.57964 \\ \mathrm{H} & 0.69797 & -1.17516 & -1.73281 \\ \mathrm{H} & 2.26949 & -0.89402 & 2.27689 \\ \mathrm{H} & 4.53519 & -1.28956 & 1.39360 \\ \mathrm{C} & -0.03128 & -0.82710 & 1.02674 \\ \mathrm{C} & -1.30076 & -1.05212 & 0.39255 \\ \mathrm{C} & -1.56893 & -1.79970 & -0.81205 \\ \mathrm{C} & -2.48864 & -0.58337 & 1.06507 \\ \mathrm{C} & -2.85182 & -1.96517 & -1.31275 \\ \mathrm{H} & -0.76305 & -2.31094 & -1.32447 \\ \mathrm{C} & -3.76041 & -0.74641 & 0.54034 \\ \mathrm{H} & -2.34617 & -0.07146 & 2.01044 \\ \mathrm{C} & -3.98072 & -1.42224 & -0.67337 \\ \mathrm{H} & -2.98020 & -2.55235 & -2.22179 \\ \mathrm{H} & -4.61050 & -0.34356 & 1.09107 \\ \mathrm{H} & -4.97867 & -1.54927 & -1.08130 \\ \mathrm{O} & -0.02326 & -0.40095 & 2.29593 \\ \mathrm{H} & -0.32754 & 0.81138 & -0.62721 \\ \mathrm{O} & -0.36025 & 1.63671 & -1.15173 \\ \mathrm{C} & 0.07129 & 2.69408 & -0.29127 \\ \mathrm{C} & 1.54649 & 2.49225 & 0.06176 \\ \mathrm{C} & -0.12454 & 3.98122 & -1.08356 \\ \mathrm{C} & -0.78028 & 2.68970 & 0.97897 \\ \mathrm{H} & 1.67479 & 1.54357 & 0.59493 \\ \mathrm{H} & 2.15026 & 2.46012 & -0.85223 \\ \mathrm{H} & 1.91188 & 3.30833 & 0.69525 \\ \mathrm{H} & -1.17897 & 4.10400 & -1.35202 \\ \mathrm{H} & 0.18797 & 4.84797 & -0.49245 \\ \mathrm{H} & 0.46812 & 3.95553 & -2.00413 \\ \mathrm{H} & -0.47183 & 3.49709 & 1.65356 \\ \mathrm{H} & -1.83580 & 2.83545 & 0.72155 \\ \mathrm{H} & -0.66880 & 1.72756 & 1.49811 \\ & & & \end{array}$


<smiles>[O-]C(c1ccccc1)c1ccccc1</smiles>

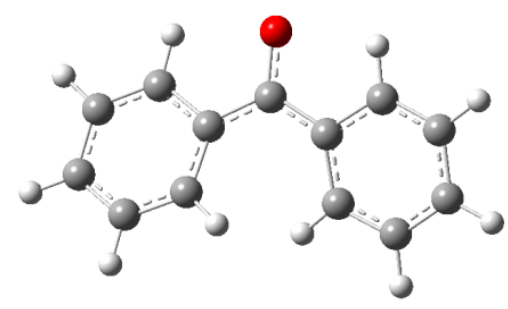

24

$-576.5430630$

$\begin{array}{llll}\text { C } & 3.93409 & -0.84781 & -0.02633\end{array}$

$\begin{array}{llll}\text { C } & 2.79551 & -1.61869 & -0.33036\end{array}$

$\begin{array}{llll}\mathrm{C} & 1.51843 & -1.07963 & -0.32629\end{array}$

$\begin{array}{llll}\text { C } & 1.26328 & 0.30324 & -0.00469\end{array}$

$\begin{array}{llll}\mathrm{C} & 2.45815 & 1.07902 & 0.22642\end{array}$

$\begin{array}{llll}\mathrm{C} & 3.72613 & 0.51879 & 0.23161\end{array}$

$\begin{array}{llll}\mathrm{H} & 4.92888 & -1.28262 & -0.02361\end{array}$

$\begin{array}{llll}\mathrm{H} & 2.91443 & -2.66815 & -0.59902\end{array}$

$\begin{array}{llll}\mathrm{H} & 0.70416 & -1.72072 & -0.64286\end{array}$

$\begin{array}{llll}\mathrm{H} & 2.32613 & 2.14010 & 0.40878\end{array}$

$\begin{array}{llll}\mathrm{H} & 4.58259 & 1.16105 & 0.43767\end{array}$

$\begin{array}{llll}\mathrm{C} & 0.00001 & 0.98227 & 0.00018\end{array}$

$\begin{array}{llll}\mathrm{C} & -1.26319 & 0.30325 & 0.00508\end{array}$

$\begin{array}{llll}\mathrm{C} & -1.51856 & -1.07953 & 0.32690\end{array}$

$\begin{array}{llll}\mathrm{C} & -2.45813 & 1.07912 & -0.22641\end{array}$

$\begin{array}{llll}\text { C } & -2.79571 & -1.61860 & 0.33027\end{array}$

$\begin{array}{llll}\mathrm{H} & -0.70468 & -1.72063 & 0.64433\end{array}$

$\begin{array}{llll}\text { C } & -3.72602 & 0.51893 & -0.23204\end{array}$

$\begin{array}{llll}\mathrm{H} & -2.32593 & 2.14023 & -0.40850\end{array}$

$\begin{array}{llll}\text { C } & -3.93412 & -0.84784 & 0.02560\end{array}$

$\begin{array}{llll}\mathrm{H} & -2.91455 & -2.66807 & 0.59896\end{array}$

$\mathrm{H} \quad-\quad-4.58245 \quad 1.16119 \quad-0.43816$

$\begin{array}{llll}\mathrm{H} & -4.92902 & -1.28243 & 0.02271\end{array}$

$\begin{array}{llll}\mathrm{O} & 0.00016 & 2.32310 & 0.00001\end{array}$

Single Point Radical Anion using Optimised Geometry 23

24

$-576.4988415$

$\begin{array}{lrrr}\mathrm{C} & 0.06673400 & 2.46635100 & 1.08064200 \\ \mathrm{C} & -0.08552000 & 1.26026900 & 0.30293700 \\ \mathrm{C} & -0.41975100 & 1.49579300 & -1.08046400 \\ \mathrm{C} & -0.49679400 & 2.77062600 & -1.61962100 \\ \mathrm{C} & -0.26265800 & 3.92476600 & -0.84791600 \\ \mathrm{C} & 0.00000000 & 3.73242900 & 0.52022600 \\ \mathrm{H} & 0.25336500 & 2.34506100 & 2.14221700 \\ \mathrm{H} & -0.68576700 & 0.66372800 & -1.72182000 \\ \mathrm{H} & -0.76913400 & 2.87357200 & -2.66984700 \\ \mathrm{H} & -0.31816800 & 4.91798700 & -1.28284000 \\ \mathrm{H} & 0.15032900 & 4.59960000 & 1.16364400 \\ \mathrm{C} & 0.00000000 & 0.00000000 & 0.98163000 \\ \mathrm{C} & 0.08552000 & -1.26026900 & 0.30293700 \\ \mathrm{C} & 0.41975100 & -1.49579300 & -1.08046400 \\ \mathrm{C} & -0.06673400 & -2.46635100 & 1.08064200 \\ \mathrm{C} & 0.49679400 & -2.77062600 & -1.61962100 \\ \mathrm{H} & 0.68576700 & -0.66372800 & -1.72182000 \\ \mathrm{C} & 0.00000000 & -3.73242900 & 0.52022600 \\ \mathrm{H} & -0.25336500 & -2.34506100 & 2.14221700 \\ \mathrm{C} & 0.26265800 & -3.92476600 & -0.84791600 \\ \mathrm{H} & 0.76913400 & -2.87357200 & -2.66984700 \\ \mathrm{H} & -0.15032900 & -4.59960000 & 1.16364400 \\ \mathrm{H} & 0.31816800 & -4.91798700 & -1.28284000 \\ \mathrm{O} & 0.00000000 & 0.00000000 & 2.32223400\end{array}$


39

$-1409.2932637$

$\begin{array}{lrrr}\mathrm{C} & 3.56791700 & -1.28791300 & -1.59990700 \\ \mathrm{C} & 2.37991400 & -0.72238500 & -2.06753500 \\ \mathrm{C} & 1.25181200 & -0.69279900 & -1.25195800 \\ \mathrm{C} & 1.31337600 & -1.21906600 & 0.04243400 \\ \mathrm{C} & 2.51048800 & -1.76844600 & 0.51559100 \\ \mathrm{C} & 3.63351200 & -1.81196700 & -0.30847600 \\ \mathrm{H} & 4.44420900 & -1.31428500 & -2.24015600 \\ \mathrm{H} & 2.33476800 & -0.29657600 & -3.06508000 \\ \mathrm{H} & 0.33720400 & -0.21548000 & -1.58723500 \\ \mathrm{H} & 2.54864400 & -2.16558900 & 1.52597400 \\ \mathrm{H} & 4.55657200 & -2.25122300 & 0.05616400 \\ \mathrm{C} & 0.14690100 & -1.15169200 & 0.97677400 \\ \mathrm{C} & -1.23124500 & -1.42876900 & 0.48090900 \\ \mathrm{C} & -1.46852700 & -2.15435600 & -0.69164100 \\ \mathrm{C} & -2.31240900 & -0.98445500 & 1.25121300 \\ \mathrm{C} & -2.77623500 & -2.41532200 & -1.09767400 \\ \mathrm{H} & -0.63731600 & -2.52790100 & -1.28113200 \\ \mathrm{C} & -3.61545400 & -1.23857300 & 0.84186700 \\ \mathrm{H} & -2.11074900 & -0.42225800 & 2.15759400 \\ \mathrm{C} & -3.84863200 & -1.95111900 & -0.33709900 \\ \mathrm{H} & -2.95706000 & -2.98072000 & -2.00618300 \\ \mathrm{H} & -4.45093600 & -0.87778200 & 1.43339500 \\ \mathrm{H} & -4.86666000 & -2.14822500 & -0.65908300 \\ \mathrm{O} & 0.34485800 & -0.91198800 & 2.16459100 \\ \mathrm{C} & -0.73007700 & 2.57544700 & -0.63723600 \\ \mathrm{C} & 0.08225100 & 2.90717200 & -1.90974700 \\ \mathrm{H} & 0.95072300 & 3.52032400 & -1.63983200 \\ \mathrm{H} & 0.45284000 & 1.98152500 & -2.36601700 \\ \mathrm{H} & -0.50633400 & 3.45079700 & -2.66045200 \\ \mathrm{C} & -1.25231200 & 3.90618200 & -0.05016500 \\ \mathrm{H} & -1.88416500 & 4.46484900 & -0.75334600 \\ \mathrm{H} & -1.83763600 & 3.69930100 & 0.85397400 \\ \mathrm{H} & -0.40405900 & 4.54148200 & 0.23248700 \\ \mathrm{C} & -1.95665400 & 1.73479700 & -1.05600600 \\ \mathrm{H} & -1.63305200 & 0.77473300 & -1.47700200 \\ \mathrm{H} & -2.57197900 & 1.51395700 & -0.17636700 \\ \mathrm{H} & -2.58043700 & 2.24794000 & -1.79990700 \\ \mathrm{O} & 0.04823300 & 1.90833600 & 0.28024700 \\ \mathrm{~K} & 1.76331200 & 1.43441800 & 1.96239100\end{array}$

Single Point Triplet using

Optimised Geometry of

Singlet Complex KOtBu+

Benzophenone

39

$-1409.2035039$

$\begin{array}{lrrr}\mathrm{C} & 3.56791700 & -1.28791300 & -1.59990700 \\ \mathrm{C} & 2.37991400 & -0.72238500 & -2.06753500 \\ \mathrm{C} & 1.25181200 & -0.69279900 & -1.25195800 \\ \mathrm{C} & 1.31337600 & -1.21906600 & 0.04243400 \\ \mathrm{C} & 2.51048800 & -1.76844600 & 0.51559100 \\ \mathrm{C} & 3.63351200 & -1.81196700 & -0.30847600 \\ \mathrm{H} & 4.44420900 & -1.31428500 & -2.24015600 \\ \mathrm{H} & 2.33476800 & -0.29657600 & -3.06508000\end{array}$ 


$\begin{array}{lrrr}\mathrm{H} & 0.33720400 & -0.21548000 & -1.58723500 \\ \mathrm{H} & 2.54864400 & -2.16558900 & 1.52597400 \\ \mathrm{H} & 4.55657200 & -2.25122300 & 0.05616400 \\ \mathrm{C} & 0.14690100 & -1.15169200 & 0.97677400 \\ \mathrm{C} & -1.23124500 & -1.42876900 & 0.48090900 \\ \mathrm{C} & -1.46852700 & -2.15435600 & -0.69164100 \\ \mathrm{C} & -2.31240900 & -0.98445500 & 1.25121300 \\ \mathrm{C} & -2.77623500 & -2.41532200 & -1.09767400 \\ \mathrm{H} & -0.63731600 & -2.52790100 & -1.28113200 \\ \mathrm{C} & -3.61545400 & -1.23857300 & 0.84186700 \\ \mathrm{H} & -2.11074900 & -0.42225800 & 2.15759400 \\ \mathrm{C} & -3.84863200 & -1.95111900 & -0.33709900 \\ \mathrm{H} & -2.95706000 & -2.98072000 & -2.00618300 \\ \mathrm{H} & -4.45093600 & -0.87778200 & 1.43339500 \\ \mathrm{H} & -4.86666000 & -2.14822500 & -0.65908300 \\ \mathrm{O} & 0.34485800 & -0.91198800 & 2.16459100 \\ \mathrm{C} & -0.73007700 & 2.57544700 & -0.63723600 \\ \mathrm{C} & 0.08225100 & 2.90717200 & -1.90974700 \\ \mathrm{H} & 0.95072300 & 3.52032400 & -1.63983200 \\ \mathrm{H} & 0.45284000 & 1.98152500 & -2.36601700 \\ \mathrm{H} & -0.50633400 & 3.45079700 & -2.66045200 \\ \mathrm{C} & -1.25231200 & 3.90618200 & -0.05016500 \\ \mathrm{H} & -1.88416500 & 4.46484900 & -0.75334600 \\ \mathrm{H} & -1.83763600 & 3.69930100 & 0.85397400 \\ \mathrm{H} & -0.40405900 & 4.54148200 & 0.23248700 \\ \mathrm{C} & -1.95665400 & 1.73479700 & -1.05600600 \\ \mathrm{H} & -1.63305200 & 0.77473300 & -1.47700200 \\ \mathrm{H} & -2.57197900 & 1.51395700 & -0.17636700 \\ \mathrm{H} & -2.58043700 & 2.24794000 & -1.79990700 \\ \mathrm{O} & 0.04823300 & 1.90833600 & 0.28024700 \\ \mathrm{~K} & 1.76331200 & 1.43441800 & 1.96239100\end{array}$

Triplet Complex KO $t \mathrm{Bu}+$ Benzophenone

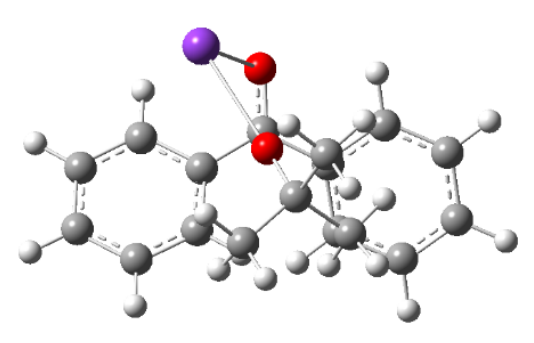

39

$-1409.2222485$

$\begin{array}{lrrr}\mathrm{C} & 3.63296200 & -0.45756700 & -1.77428500 \\ \mathrm{C} & 2.34970700 & -0.07100200 & -2.18334200 \\ \mathrm{C} & 1.22615500 & -0.42428800 & -1.44769900 \\ \mathrm{C} & 1.33001100 & -1.19261300 & -0.25680500 \\ \mathrm{C} & 2.64404800 & -1.55249400 & 0.15084500 \\ \mathrm{C} & 3.76273500 & -1.19774400 & -0.59444100 \\ \mathrm{H} & 4.50647600 & -0.18073400 & -2.35543400 \\ \mathrm{H} & 2.22689600 & 0.52723400 & -3.08300500 \\ \mathrm{H} & 0.25398900 & -0.07304300 & -1.77642900 \\ \mathrm{H} & 2.75438100 & -2.13583600 & 1.06054100 \\ \mathrm{H} & 4.74815500 & -1.50784700 & -0.25598600 \\ \mathrm{C} & 0.21217900 & -1.52023000 & 0.62335000 \\ \mathrm{C} & -1.18173800 & -1.51550100 & 0.16200800 \\ \mathrm{C} & -1.58022300 & -1.73491100 & -1.17567500 \\ \mathrm{C} & -2.20720000 & -1.34821100 & 1.12057400 \\ \mathrm{C} & -2.92268700 & -1.72526200 & -1.53895300 \\ \mathrm{H} & -0.83192900 & -1.94260600 & -1.93427900 \\ \mathrm{C} & -3.54785600 & -1.33680700 & 0.75357400 \\ \mathrm{H} & -1.91886300 & -1.21691100 & 2.15868600 \\ \mathrm{C} & -3.92082100 & -1.51134100 & -0.58277900 \\ \mathrm{H} & -3.19463900 & -1.90041600 & -2.57653100 \\ \mathrm{H} & -4.31074500 & -1.18916000 & 1.51360300 \\ \mathrm{H} & -4.96752400 & -1.50173200 & -0.87070200\end{array}$




$\begin{array}{lrrr}\mathrm{O} & 0.45664400 & -1.76516200 & 1.86940600 \\ \mathrm{C} & -0.74974500 & 2.57995100 & -0.25854800 \\ \mathrm{C} & 0.15573100 & 3.25602300 & -1.28973600 \\ \mathrm{H} & 0.96802700 & 3.79135700 & -0.79015100 \\ \mathrm{H} & 0.58940900 & 2.50260400 & -1.95432300 \\ \mathrm{H} & -0.41807500 & 3.96451600 & -1.89442700 \\ \mathrm{C} & -1.28439300 & 3.62538100 & 0.75910200 \\ \mathrm{H} & -1.86284400 & 4.36399300 & 0.19742000 \\ \mathrm{H} & -1.93210900 & 3.14491400 & 1.49554900 \\ \mathrm{H} & -0.45818200 & 4.12838200 & 1.26640900 \\ \mathrm{C} & -1.92290000 & 1.84412500 & -0.91174200 \\ \mathrm{H} & -1.56172500 & 1.13209800 & -1.65881300 \\ \mathrm{H} & -2.49169000 & 1.28547500 & -0.16244900 \\ \mathrm{H} & -2.58147800 & 2.56176100 & -1.41046700 \\ \mathrm{O} & -0.01759300 & 1.73108200 & 0.55644000 \\ \mathrm{~K} & 1.63127800 & 0.53755500 & 2.33112300\end{array}$

Single Point Singlet using

Optimised Geometry of

Triplet Complex KO $t \mathrm{Bu}+$

Benzophenone

39

$-1409.2708159$

$\begin{array}{lrrr}\mathrm{C} & 3.63296200 & -0.45756800 & -1.77428500 \\ \mathrm{C} & 2.34970700 & -0.07100200 & -2.18334200 \\ \mathrm{C} & 1.22615500 & -0.42428800 & -1.44769900 \\ \mathrm{C} & 1.33001100 & -1.19261300 & -0.25680500 \\ \mathrm{C} & 2.64404800 & -1.55249500 & 0.15084500 \\ \mathrm{C} & 3.76273500 & -1.19774500 & -0.59444100 \\ \mathrm{H} & 4.50647600 & -0.18073500 & -2.35543400 \\ \mathrm{H} & 2.22689600 & 0.52723400 & -3.08300500 \\ \mathrm{H} & 0.25398900 & -0.07304300 & -1.77642900 \\ \mathrm{H} & 2.75438100 & -2.13583700 & 1.06054100 \\ \mathrm{H} & 4.74815500 & -1.50784800 & -0.25598600 \\ \mathrm{C} & 0.21217900 & -1.52023000 & 0.62335000 \\ \mathrm{C} & -1.18173800 & -1.51550100 & 0.16200800 \\ \mathrm{C} & -1.58022300 & -1.73491100 & -1.17567500 \\ \mathrm{C} & -2.20720000 & -1.34821100 & 1.12057400 \\ \mathrm{C} & -2.92268700 & -1.72526200 & -1.53895300 \\ \mathrm{H} & -0.83192900 & -1.94260600 & -1.93427900 \\ \mathrm{C} & -3.54785600 & -1.33680600 & 0.75357400 \\ \mathrm{H} & -1.91886300 & -1.21691100 & 2.15868600 \\ \mathrm{C} & -3.92082100 & -1.51134000 & -0.58277900 \\ \mathrm{H} & -3.19463900 & -1.90041500 & -2.57653100 \\ \mathrm{H} & -4.31074500 & -1.18915900 & 1.51360300 \\ \mathrm{H} & -4.96752400 & -1.50173100 & -0.87070200 \\ \mathrm{O} & 0.45664400 & -1.76516200 & 1.86940600 \\ \mathrm{C} & -0.74974500 & 2.57995100 & -0.25854800 \\ \mathrm{C} & 0.15573100 & 3.25602300 & -1.28973600 \\ \mathrm{H} & 0.96802800 & 3.79135700 & -0.79015100 \\ \mathrm{H} & 0.58940900 & 2.50260400 & -1.95432300 \\ \mathrm{H} & -0.41807400 & 3.96451600 & -1.89442700 \\ \mathrm{C} & -1.28439200 & 3.62538100 & 0.75910200 \\ \mathrm{H} & -1.86284300 & 4.36399300 & 0.19742000 \\ \mathrm{H} & -1.93210900 & 3.14491400 & 1.49554900 \\ \mathrm{H} & -0.45818100 & 4.12838200 & 1.26640900 \\ \mathrm{C} & -1.92290000 & 1.84412500 & -0.91174200 \\ \mathrm{H} & -1.56172500 & 1.13209800 & -1.65881300 \\ \mathrm{H} & -2.49169000 & 1.28547500 & -0.16244900 \\ \mathrm{H} & -2.58147800 & 2.56176100 & -1.41046700 \\ \mathrm{O} & -0.01759300 & 1.73108200 & 0.55644000 \\ \mathrm{~K} & 1.63127800 & 0.53755500 & 2.33112300\end{array}$


Benzophenone complex with $\mathrm{NaO} t \mathrm{Bu}$

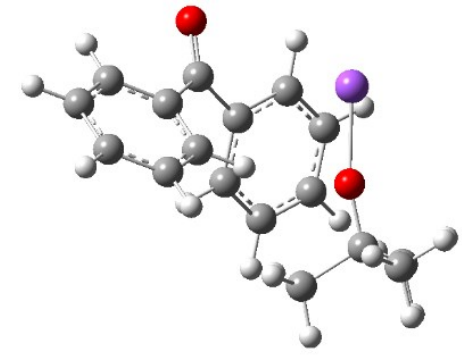

39

$-971.7183487$

$\begin{array}{lrrr}\mathrm{C} & 1.75878 & 3.01639 & -1.07029 \\ \mathrm{C} & 1.04574 & 2.10808 & -1.85180 \\ \mathrm{C} & -0.12554 & 1.53527 & -1.36098 \\ \mathrm{C} & -0.59872 & 1.88760 & -0.09223 \\ \mathrm{C} & 0.10943 & 2.81591 & 0.68025 \\ \mathrm{C} & 1.29221 & 3.36836 & 0.19807 \\ \mathrm{H} & 2.68089 & 3.44779 & -1.44761 \\ \mathrm{H} & 1.40675 & 1.83618 & -2.83869 \\ \mathrm{H} & -0.67616 & 0.82272 & -1.96775 \\ \mathrm{H} & -0.27567 & 3.09088 & 1.65782 \\ \mathrm{H} & 1.84947 & 4.07383 & 0.80611 \\ \mathrm{C} & -1.87998 & 1.33464 & 0.44584 \\ \mathrm{C} & -2.31700 & -0.03488 & 0.03283 \\ \mathrm{C} & -1.39267 & -1.07007 & -0.16243 \\ \mathrm{C} & -3.68875 & -0.28193 & -0.10037 \\ \mathrm{C} & -1.85437 & -2.34562 & -0.48891 \\ \mathrm{H} & -0.32059 & -0.90834 & -0.02255 \\ \mathrm{C} & -4.13824 & -1.55008 & -0.45425 \\ \mathrm{H} & -4.39067 & 0.52989 & 0.06523 \\ \mathrm{C} & -3.21929 & -2.58443 & -0.64698 \\ \mathrm{H} & -1.14129 & -3.15381 & -0.62131 \\ \mathrm{H} & -5.20067 & -1.73494 & -0.57717 \\ \mathrm{H} & -3.56913 & -3.57617 & -0.91713 \\ \mathrm{O} & -2.56374 & 1.99739 & 1.21437 \\ \mathrm{O} & 1.73406 & -1.13754 & 0.93557 \\ \mathrm{C} & 2.65690 & -1.56193 & 0.00418 \\ \mathrm{C} & 3.72705 & -0.47802 & -0.23993 \\ \mathrm{C} & 3.36609 & -2.84330 & 0.48772 \\ \mathrm{C} & 1.96886 & -1.86779 & -1.34288 \\ \mathrm{H} & 3.24383 & 0.44005 & -0.59543 \\ \mathrm{H} & 4.24375 & -0.25101 & 0.70030 \\ \mathrm{H} & 4.47633 & -0.78615 & -0.98056 \\ \mathrm{H} & 2.62509 & -3.63425 & 0.65293 \\ \mathrm{H} & 4.11037 & -3.21063 & -0.23034 \\ \mathrm{H} & 3.87206 & -2.64606 & 1.44034 \\ \mathrm{H} & 2.67877 & -2.20545 & -2.10860 \\ \mathrm{H} & 1.21336 & -2.65065 & -1.20438 \\ \mathrm{H} & 1.46257 & -0.96728 & -1.71207 \\ \mathrm{Na} & 0.73503 & -0.37133 & 2.58857 \\ & & & \\ & & & \end{array}$




\section{References}

1. Gibson, H. W.; Lee, S. H.; Engen, P. T.; Lecavalier, P.; Sze, J.; Shen, Y. X.; Bheda, M., J. Org. Chem. 1993, 58, 37483756.

2. Li, Y.; Lu, W.; Xue, D.; Wang, C.; Liu, Z.-T.; Xiao, J., Synlett 2014, 25, 1097-1100.

3. Maslak, P.; Varadarajan, S.; Burkey, J. D., J. Org. Chem. 1999, 64, 8201-8209.

4. Grilli, S.; Lunazzi, L.; Mazzanti, A.; Casarini, D.; Femoni, C., J. Org. Chem. 2001, 66, 488-495.

5. Reimann, S.; Ehlers, P.; Sharif, M.; Spannenberg, A.; Langer, P., Tetrahedron 2016, 72, 1083-1094.

6. Baddeley, G., J. Chem. Soc. 1944, 330-332.

7. Wang, D.; Zhang, Z., Org. Lett. 2003, 5 , 4645-4648.

8. Scott, T. A.; Ooro, B. A.; Collins, D. J.; Shatruk, M.; Yakovenko, A.; Dunbar, K. R.; Zhou, H.-C., Chem. Comm. 2009, 65-67.

9. Frisch, M. J.; Trucks, G. W.; Schlegel, H. B.; Scuseria, G. E.; Robb, M. A.; Cheeseman, J. R.; Scalmani, G.; Barone, V.; Mennucci, B.; Petersson, G. A.; Nakatsuji, H.; Caricato, M.; Li, X.; Hratchian, H. P.; Izmaylov, A. F.; Bloino, J.; Zheng, G.; Sonnenberg, J. L.; Hada, M.; Ehara, M.; Toyota, K.; Fukuda, R.; Hasegawa, J.; Ishida, M.; Nakajima, T.; Honda, Y.; Kitao, O.; Nakai, H.; Vreven, T.; Montgomery, J. A., Jr.; Peralta, J. E.; Ogliaro, F.; Bearpark, M.; Heyd, J. J.; Brothers, E.; Kudin, K. N.; Staroverov, V. N.; Kobayashi, R.; Normand, J.; Raghavachari, K.; Rendell, A.; Burant, J. C.; Iyengar, S. S.; Tomasi, J.; Cossi, M.; Rega, N.; Millam, J. M.; Klene, M.; Knox, J. E.; Cross, J. B.; Bakken, V.; Adamo, C.; Jaramillo, J.; Gomperts, R.; Stratmann, R. E.; Yazyev, O.; Austin, A. J.; Cammi, R.; Pomelli, C.; Ochterski, J. W.; Martin, R. L.; Morokuma, K.; Zakrzewski, V. G.; Voth, G. A.; Salvador, P.; Dannenberg, J. J.; Dapprich, S.; Daniels, A. D.; Farkas, Ö.; Foresman, J. B.; Ortiz, J. V.; Cioslowski, J.; Fox, D. J. Gaussian 09, Revision A.02, Gaussian, Inc., Wallingford CT: 2009.

10.Zhao, Y.; Truhlar, D. G., Theor. Chem. Acc. 2008, 120, 215-241.

11.Rassolov, V. A.; Ratner, M. A.; Pople, J. A.; Redfern, P. C.; Curtiss, L. A., J. Comput. Chem. 2001, 22, 976-984.

12.Cossi, M.; Rega, N.; Scalmani, G.; Barone, V., J. Comput. Chem. 2003, 24, 669-681.

13.Scalmani, G.; Frisch, M. J.; Mennucci, B.; Tomasi, J.; Cammi, R.; Barone, V., J. Chem. Phys. 2006, 124, 094107.

14.Yanai, T.; Tew, D. P.; Handy, N. C., Chem. Phys. Lett. 2004, 393, 51-57.

15.Peach, M. J. G.; Benfield, P.; Helgaker, T.; Tozer, D. J., J. Chem. Phys. 2008, 128, 044118.

16.Banerjee, S.; Yang, Y.-F.; Jenkins, I. D.; Liang, Y.; Toutov, A. A.; Liu, W.-B.; Schuman, D. P.; Grubbs, R. H.; Stoltz, B. M.; Krenske, E. H., J. Am. Chem. Soc. 2017, 139, 6880-6887.

17.Liu, W. B.; Schuman, D. P.; Yang, Y. F.; Toutov, A. A.; Liang, Y.; Klare, H. F. T.; Nesnas, N.; Oestreich, M.; Blackmond, D. G.; Virgil, S. C.; Banerjee, S.; Zare, R. N.; Grubbs, R. H.; Houk, K. N.; Stoltz, B. M., J. Am. Chem. Soc. 2017, 139, 6867-6879.

18.Marcus, R. A., J. Chem. Phys. 1965, 43, 679-701.

19.Nelsen, S. F.; Blackstock, S. C.; Kim, Y., J. Am. Chem. Soc. 1987, 109, 677-682.

20.Anderson, G. M.; Cameron, I.; Murphy, J. A.; Tuttle, T., RSC Adv. 2016, 6, 11335-11343.

21.Doni, E.; Murphy, J. A., Chem. Comm. 2014, 50, 6073-6087.

22.Ashby, E. C., Acc. Chem. Res. 1988, 21, 414-421.

23.Ashby, E. C.; Argyropoulos, J. N., J. Org. Chem. 1986, 51, 3593-3597.

24.Ashby, E. C.; Argyropoulos, J. N., Tetrahedron Lett. 1986, 27, 465-468.

25.Ashby, E. C.; Goel, A. B.; Argyropoulos, J. N., Tetrahedron Lett. 1982, 23, 2273-2276. 